Groundwater Availability and Use Assessments

Prepared in cooperation with Santa Barbara County Water Agency and Vandenberg Space Force Base

\title{
Hydrogeologic Characterization of the San Antonio Creek Valley Watershed, Santa Barbara County, California
}

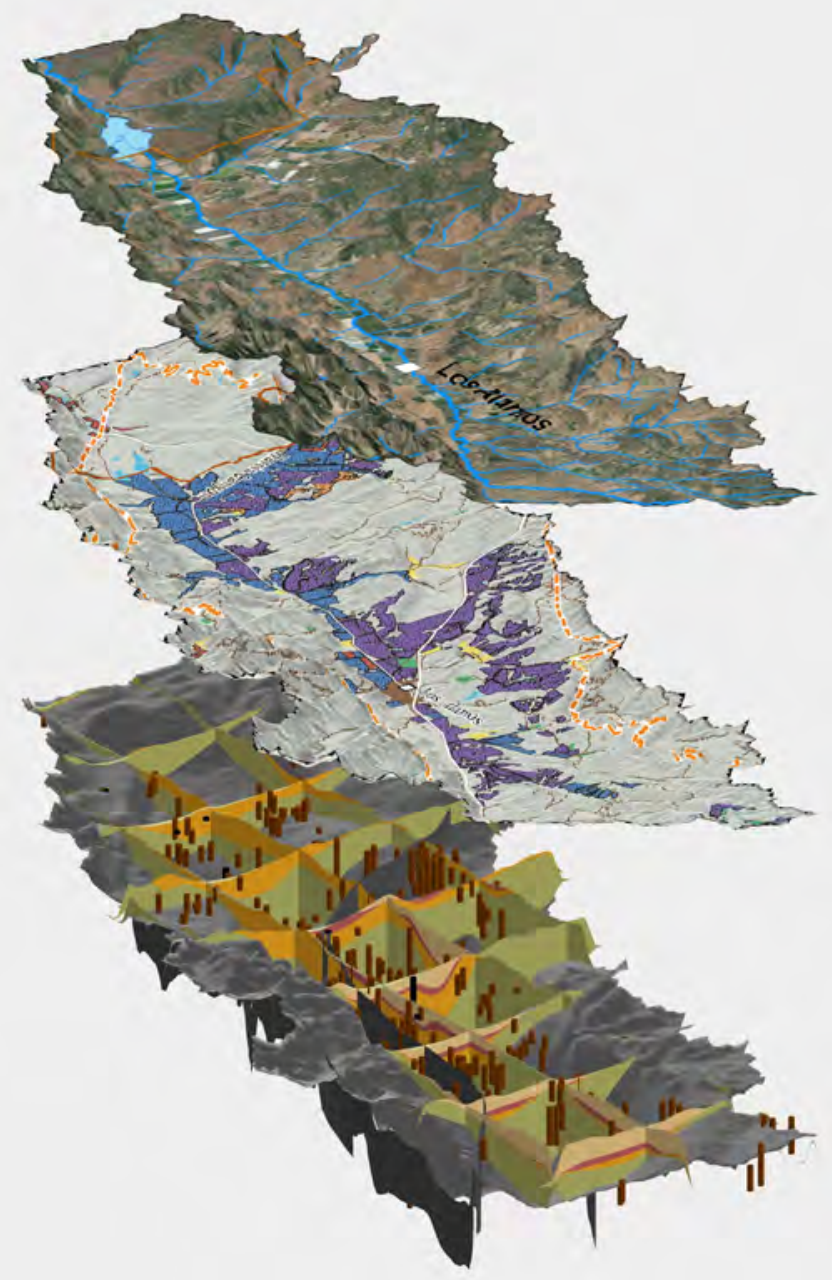

Scientific Investigations Report 2022-5001 
Cover: Visualization of the three-dimensional hydrogeologic framework model and land use of the San Antonio Creek Valley watershed. 


\section{Hydrogeologic Characterization of the San Antonio Creek Valley Watershed, Santa Barbara County, California}

By Geoffrey Cromwell, Donald S. Sweetkind, Jill N. Densmore, John A. Engott, Whitney A. Seymour, Joshua D. Larsen, Christopher P. Ely, Christina L. Stamos, Claudia C. Faunt

Groundwater Availability and Use Assessments

Prepared in cooperation with Santa Barbara County Water Agency and Vandenberg Space Force Base

Scientific Investigations Report 2022-5001 


\section{U.S. Geological Survey, Reston, Virginia: 2022}

For more information on the USGS - the Federal source for science about the Earth, its natural and living resources, natural hazards, and the environment—visit https://www.usgs.gov or call 1-888-ASK-USGS.

For an overview of USGS information products, including maps, imagery, and publications, visit https://store.usgs.gov/.

Any use of trade, firm, or product names is for descriptive purposes only and does not imply endorsement by the U.S. Government.

Although this information product, for the most part, is in the public domain, it also may contain copyrighted materials as noted in the text. Permission to reproduce copyrighted items must be secured from the copyright owner.

Suggested citation:

Cromwell, G., Sweetkind, D.S., Densmore, J.N., Engott, J.A., Seymour, W.A., Larsen, J.D., Ely, C.P., Stamos, C.L., and Faunt, C.C., 2022, Hydrogeologic characterization of the San Antonio Creek Valley watershed, Santa Barbara County, California: U.S. Geological Survey Scientific Investigations Report 2022-5001, 124 p., https://doi.org/10.3133/sir20225001.

Associated data for this publication:

Ely, C.P., Cromwell, G., Sweetkind, D.S., Larsen, J.D. Kohel, C.A., and O'Leary, D.R., 2022, Data release of hydrogeologic data from the San Antonio Creek Valley watershed, Santa Barbara County, California: U.S. Geological Survey data release. [Available at https://doi.org/10.5066/P9AD7DL8.]

ISSN 2328-0328 (online) 


\section{Acknowledgments}

The authors thank the Santa Barbara County Water Agency and Vandenberg Space Force Base for their cooperation on this project, including funding, expertise, and logistical support for data collection and analysis. The Cachuma Resource Conservation District facilitated community involvement with stakeholders in the San Antonio Creek area, and landowners in the San Antonio Creek area provided access for data collection and local and historical expertise about the area. In particular, we want to express appreciation for the guidance and dedication that Dennis Gibbs, former Hydrologist at Santa Barbara County Water Agency, gave to this project in its formative years.

The authors thank USGS colleagues for assistance in data collection, analysis, and support, including the staff at the Santa Maria Field Office, Steve Crawford, the Western Region Research Drilling team, Adam Kjos, Chris Kohel, Ryan Mesmer, Tony Brown, Mike Lee, Milissa Peterson, Sarah Roberts, Meghan Dick, Sandra Bond, and Anthony McCarlson. Finally, we want to express special acknowledgment to and recognize the leadership that Dave O'Leary provided to this project for a number of years. His hard work resulted in significant influence on the available data and interpretations. 



\section{Contents}

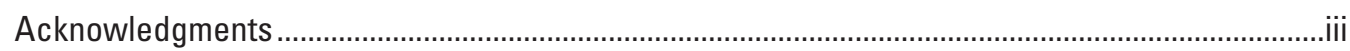

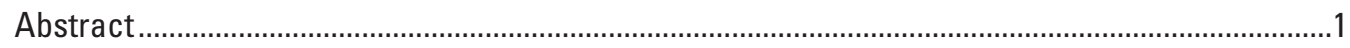

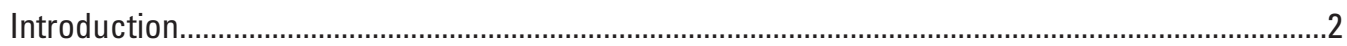

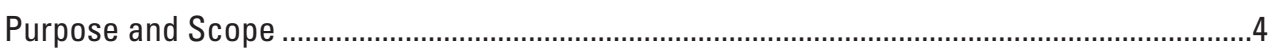

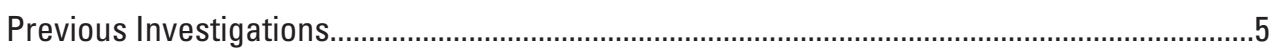

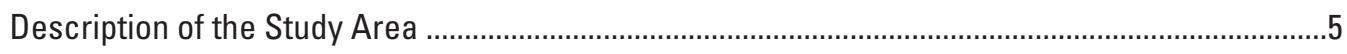

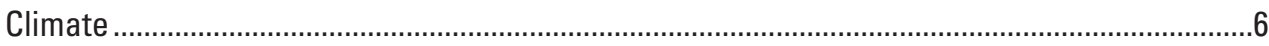

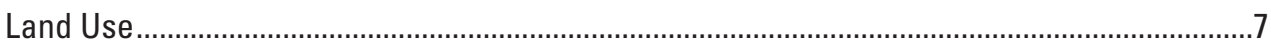

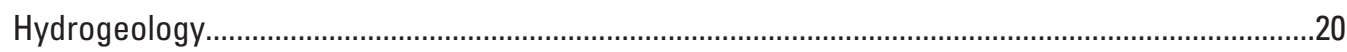

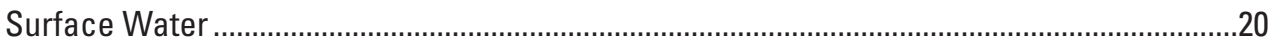

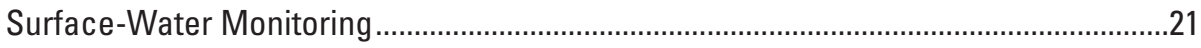

Base Flow to San Antonio Creek....................................................................................25

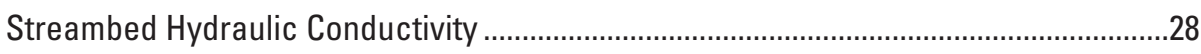

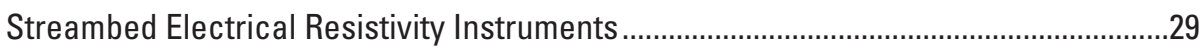

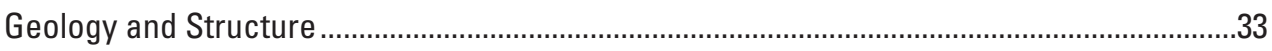

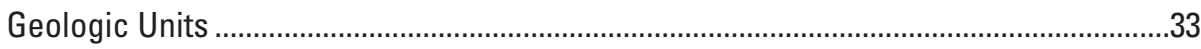

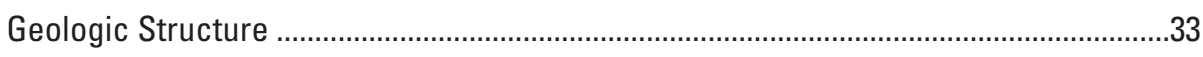

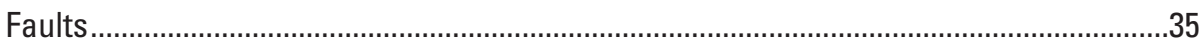

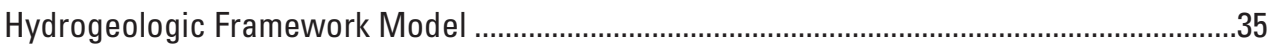

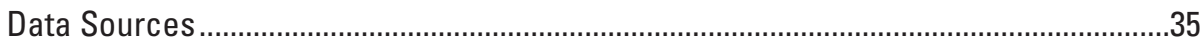

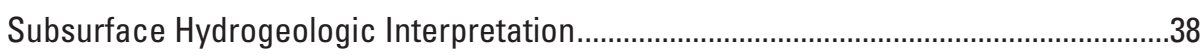

Subdivision of the Paso Robles Formation .................................................................38

Framework Model Construction and Results..............................................................39

Framework Model Summary and Limitations ..............................................................4

Definition of the Aquifer System ..................................................................................... 47

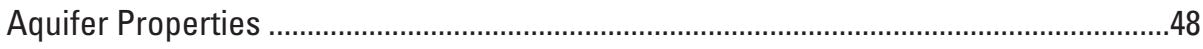

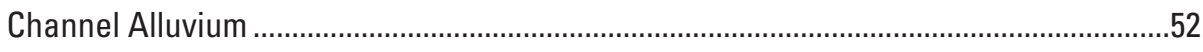

Lower, Middle, and Upper Members of the Paso Robles Formation ...............................52

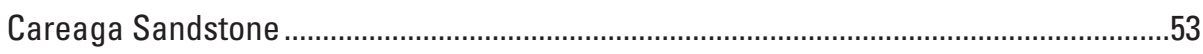

Consolidated Bedrock....................................................................................................

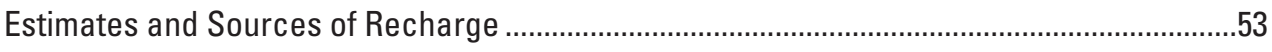

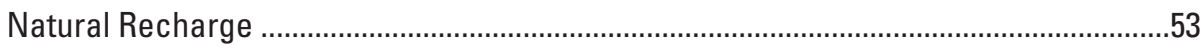

Infiltration from Precipitation and Streamflow ....................................................53

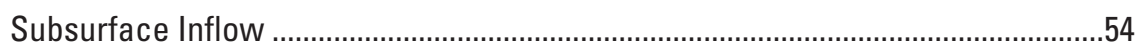

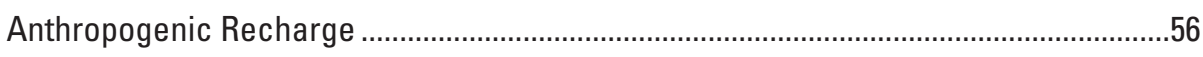

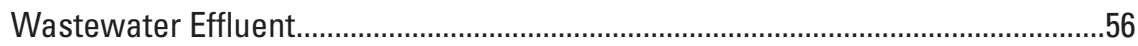

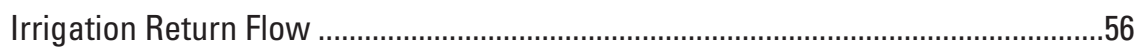

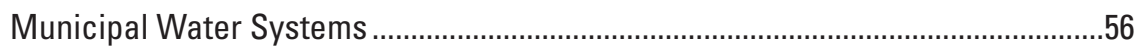

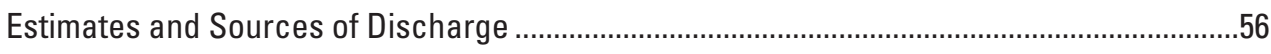

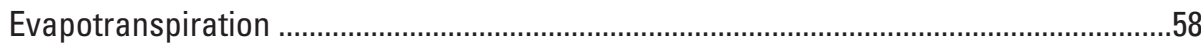

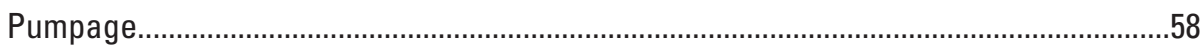

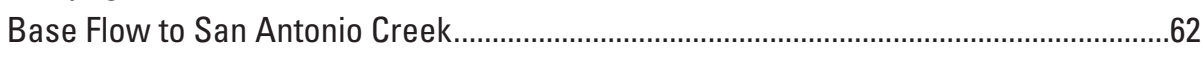

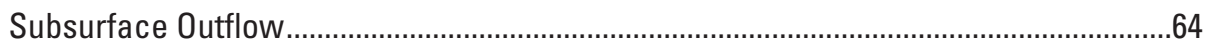


Groundwater Levels, Flow, and Movement........................................................................

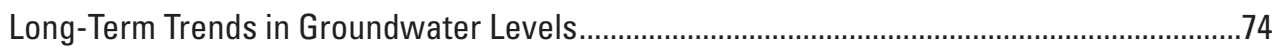

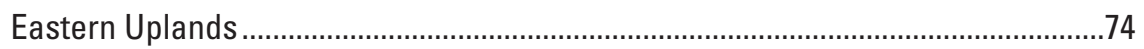

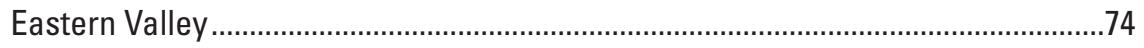

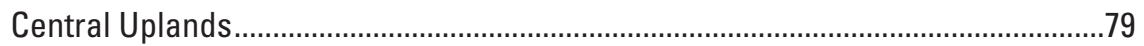

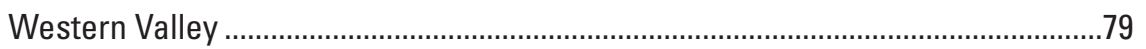

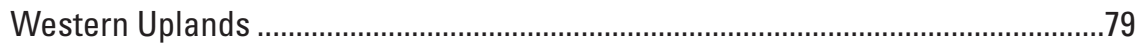

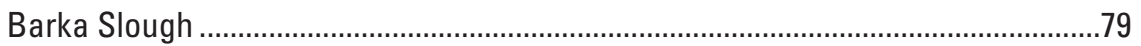

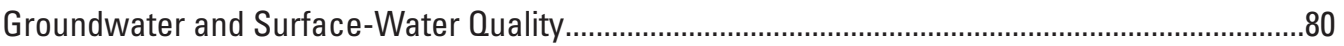

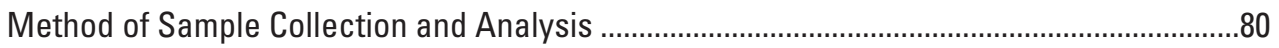

Chemical Composition of Surface-Water and Groundwater....................................................82

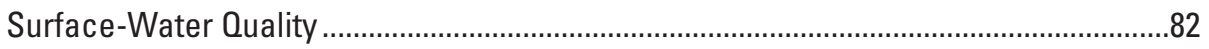

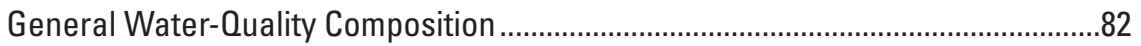

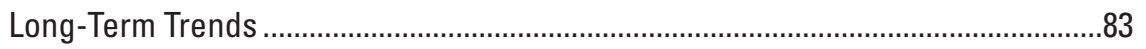

Groundwater Quality ............................................................................................ 86

General Water-Quality Composition ........................................................................86

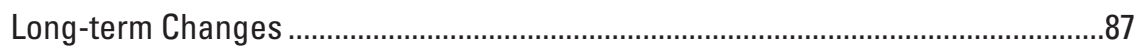

Reduction/Oxidation Conditions of Groundwater....................................................91

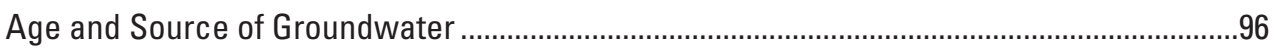

Tritium and Carbon-14 …...........................................................................................96

Stable Isotopes of Oxygen and Hydrogen ...................................................................

Summary

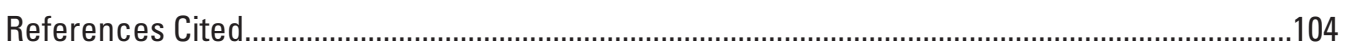

Appendix 1. Supplementary Information on Population, Streambed Electrical Resistivity

Instruments, and U.S. Geological Survey Monitoring Wells.............................................112

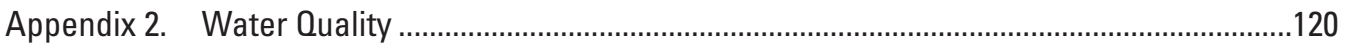

\section{Figures}

1. Map showing location of the San Antonio Creek Valley groundwater basin and the San Antonio Creek Valley watershed, Santa Barbara County, California .

2. Map showing the San Antonio Creek Valley groundwater basin and the San Antonio Creek Valley watershed, Santa Barbara County, California ...

3. Graph showing mean monthly precipitation during water years 1948 to 2018, San Antonio Creek Valley watershed, Santa Barbara, California ....................................6

4. Graph showing annual precipitation during water years 1948-2018, San Antonio Creek Valley Watershed, Santa Barbara, California....

5. Map showing contours of mean annual precipitation during 1981-2010, San Antonio Creek Valley watershed, Santa Barbara, California ..............................................8

6. Land-use maps showing selected years, San Antonio Creek Valley watershed, Santa Barbara County, California.

7. Bar charts showing changes in land use and agricultural land-use for 1959, 1968, 1977, 1986, 1996, 2006, and 2016 for the San Antonio Creek Valley watershed, Santa Barbara County, California 
8. Map showing location of U.S. Geological Survey streamgages, infiltrometer sites, and streambed instruments in the San Antonio Creek Valley watershed, Santa Barbara County, California.

9. Graphs showing mean annual streamflow at U.S. Geological Survey streamgages in the San Antonio Creek Valley watershed, Santa Barbara County, California. Annual precipitation shown from a climate station in Los Alamos. Streamflow is shown only for water years with complete records.

10. Graphs showing mean monthly streamflow during water years 1948-2018 at U.S. Geological Survey stations 11135800 and 111361000 on San Antonio Creek, San Antonio Creek Valley Watershed, Santa Barbara County, California

11. Graphs showing measured daily streamflow and estimated daily base flow at U.S. Geological Survey station 11136100 during a wet water year and a dry water year, San Antonio Creek Valley watershed, Santa Barbara County, California....26

12. Graph showing base flow at U.S. Geological Survey station 11136100 for water years 1956-2003 and 2016-18 and estimated average, wet, and dry annual precipitation, San Antonio Creek Valley watershed, Santa Barbara County, California

13. Plots showing estimated aquifer properties at streambed infiltrometer infiltrometer test sites along the main channel of San Antonio Creek and tributary streambeds, San Antonio Creek Valley watershed, Santa Barbara County, California.

14. Graphs showing percent relative conductance of streambed electrical resistivity sensor SERS-6 compared to daily precipitation recorded at climate station 204, Los Alamos Fire Station \#24; and daily streamflow from U.S. Geological survey stations 11135800, 111360460, and 11136100 San Antonio Creek Valley watershed, Santa Barbara County, California.

15. Graphs showing percent relative conductance of streambed electrical resistivity sensor SERS-3 compared to daily precipitation recorded at climate station 204, Los Alamos Fire Station \#24, and daily streamflow from U.S. Geological survey stations 11135800, 111360460, and 11136100, San Antonio Creek Valley watershed, Santa Barbara County, California.

16. Map showing the geology of the San Antonio Creek Valley Watershed, Santa Barbara County, California

17. Map showing the hydrogeologic units of the San Antonio Creek Valley watershed, Santa Barbara County, California

18. Graphs showing borehole lithology and geophysical logs for U.S. Geological Survey multiple-depth, monitoring-well sites SACR and SACC, San Antonio Creek Valley watershed, Santa Barbara County, California.

19. Graphs showing measured groundwater elevations during 2016-18 for U.S Geological Survey multiple-depth, monitoring-well sites SACR and SACC, San Antonio Creek Valley watershed, Santa Barbara County, California

20. Conceptual hydrogeologic section showing U.S. Geological Survey multiple-depth, monitoring-well sites SACR and SACC

21. Map showing elevation of the consolidated bedrock from the three-dimensional hydrogeologic framework model, San Antonio Creek Valley watershed, Santa Barbara County, California

22. Maps showing extent and thickness of basin-fill hydrogeologic units from the three-dimensional hydrogeologic framework model, and the estimated percentage of coarse-grained materials for boreholes that penetrate each unit 
23. Egg-crate diagram showing the three-dimensional hydrogeologic framework model for San Antonio Creek Valley watershed, Santa Barbara County, California .......45

24. Generalized cross sections showing the three-dimensional hydrogeologic framework model of the San Antonio Creek Valley watershed, Santa Barbara County, California... .46

25. Plots showing measured aquifer properties of hydrogeologic units in the San Antonio Creek Valley watershed, Santa Barbara County, California .50

26. Graphs showing frequency of coarse-grained materials, in percent, from borehole logs for basin-fill hydrogeologic units of the San Antonio Creek Valley watershed, Santa Barbara County, California

27. Graph showing reported estimates of natural recharge during calendar years 1948-2018, San Antonio Creek Valley watershed, Santa Barbara County, California.....54

28. Map showing locations of anthropogenic recharge and pumpage, San Antonio Creek Valley watershed, Santa Barbara County, California 55

29. Graphs showing estimated annual anthropogenic recharge during water years 1948-2018, all sources of anthropogenic recharge, and sources of anthropogenic recharge not including agricultural irrigation return, San Antonio Creek Valley watershed, Santa Barbara County, California

30. Graphs showing annual and cumulative pumpage during 1948-2018, all water uses and water uses not including agriculture, San Antonio Creek Valley watershed, Santa Barbara County, California

31. Graphs showing best-fit line equations and coefficients of determination that describe relations between net annual pumpage and annual base flow at U.S. Geological Survey station 11136100 during years with average annual precipitation for water years 1956-90; and water years 1991-2003, San Antonio Creek Valley watershed, Santa Barbara County, California

32. Maps showing groundwater elevation in the San Antonio Creek Valley watershed for December 1943; January 1978; and water year 2017

33. Cross-section showing the three-dimensional hydrogeologic framework model showing estimated groundwater elevations from groundwater-elevation contour maps for December 1943, January 1978, and water year 2017

34. Map showing location of selected wells with groundwater-elevation hydrographs, San Antonio Creek Valley watershed, Santa Barbara County, California

35. Graphs showing measured groundwater elevations for selected wells for calendar years 1948-2018, San Antonio Creek Valley watershed, Santa Barbara County, California

36. Map showing location of select groundwater and surface-water quality sites, San Antonio Creek Valley watershed, Santa Barbara County, California....

37. Graph showing annual precipitation and concentrations of total dissolved solids and chloride at U.S. Geological Survey stations 11136040, 11135800, and 11136100, San Antonio Creek Valley watershed, Santa Barbara County, California .......83

38. Cross-sections showing water-quality diagrams and total dissolved-solids concentration for select wells and surface-water sites, San Antonio Creek Valley watershed, Santa Barbara County, California

39. Maps showing chemigraphs of water-quality data from selected wells showing total dissolved solids and chloride, nitrate, and calcium and magnesium, San Antonio Creek watershed, Santa Barbara County, California. 
40. Cross-sections showing concentrations of tritium as tritium units and percent modern carbon in groundwater, and groupings of stable isotope compositions of groundwater in selected wells; section $D-D^{\prime}$; section $E-E^{\prime}$; section $F-F^{\prime}$; and section G-G'; San Antonio Creek Valley watershed, Santa Barbara County, California .

41. Graphs showing stable isotope concentrations in parts per thousand (per mil) for groundwater samples from selected wells, San Antonio Creek Valley watershed, Santa Barbara County, California ....

42. Map showing groups of stable isotopic concentrations and well depth from selected groundwater samples, San Antonio Creek Valley watershed, Santa Barbara County, California

\section{Tables}

1. General land-use categories with corresponding Landscape Fire and Resource Management Planning Tools version 140, California Department of Water Resources, and Farmland Mapping \& Monitoring Program vegetation codes and classes for 1959, 1968, 1977, 1986, 1996, 2006, and 2016, San Antonio Creek Valley Watershed, Santa Barbara County, California

2. General land-use categories and agricultural sub-categories for 1959, 1968, 1977, 1986, 1996, 2006, and 2016 San Antonio Creek Valley Watershed, Santa Barbara County, California

3. Description and summary monthly statistics of USGS streamgages active during water years 1948-2018 in the San Antonio Creek Valley watershed, Santa Barbara County, California.

4. Estimates of base flow at U.S. Geological Survey station 11136100 from this study and from previous studies using available measured streamflow data during water years 1956-2018, San Antonio Creek Valley watershed, Santa Barbara County, California

5. Estimated aquifer properties from streambed infiltrometer test sites, San Antonio Creek Valley watershed, Santa Barbara County, California

6. Streambed electrical resistivity instrument locations, San Antonio Creek Valley watershed, Santa Barbara County, California

7. Well information, hydraulic conductivity estimates, and measurement data from aquifer slug tests for U.S. Geological Survey single- and multiple-depth, monitoring well sites and monitoring well 8N/34W-21A1, San Antonio Creek Valley watershed, Santa Barbara County, California

8. Annual groundwater pumpage during 1948-2018, San Antonio Creek Valley watershed, Santa Barbara County, California

9. Selected wells with groundwater-level and water-quality data and streamgages with water-quality data, San Antonio Creek Valley watershed, California .

10. Redox conditions of select groundwater samples from wells in the San Antonio Creek Valley Watershed, Santa Barbara County, California 


\section{Conversion Factors}

U.S. customary units to International System of Units

\begin{tabular}{|c|c|c|}
\hline Multiply & By & To obtain \\
\hline \multicolumn{3}{|c|}{ Length } \\
\hline inch (in.) & 2.54 & centimeter $(\mathrm{cm})$ \\
\hline inch (in.) & 25.4 & millimeter (mm) \\
\hline foot $(\mathrm{ft})$ & 0.3048 & $\operatorname{meter}(\mathrm{m})$ \\
\hline mile (mi) & 1.609 & kilometer (km) \\
\hline \multicolumn{3}{|c|}{ Area } \\
\hline Acre & 4,047 & square meter $\left(\mathrm{m}^{2}\right)$ \\
\hline Acre & 0.4047 & hectare (ha) \\
\hline Acre & 0.4047 & square hectometer $\left(\mathrm{hm}^{2}\right)$ \\
\hline Acre & 0.004047 & square kilometer $\left(\mathrm{km}^{2}\right)$ \\
\hline square foot $\left(\mathrm{ft}^{2}\right)$ & 929.0 & square centimeter $\left(\mathrm{cm}^{2}\right)$ \\
\hline square foot $\left(\mathrm{ft}^{2}\right)$ & 0.09290 & square meter $\left(\mathrm{m}^{2}\right)$ \\
\hline square inch (in²) & 6.452 & square centimeter $\left(\mathrm{cm}^{2}\right)$ \\
\hline square mile $\left(\mathrm{mi}^{2}\right)$ & 259.0 & hectare (ha) \\
\hline square mile $\left(\mathrm{mi}^{2}\right)$ & 2.590 & square kilometer $\left(\mathrm{km}^{2}\right)$ \\
\hline \multicolumn{3}{|c|}{ Volume } \\
\hline gallon (gal) & 3.785 & liter $(\mathrm{L})$ \\
\hline gallon (gal) & 0.003785 & cubic meter $\left(\mathrm{m}^{3}\right)$ \\
\hline gallon (gal) & 3.785 & cubic decimeter $\left(\mathrm{dm}^{3}\right)$ \\
\hline cubic foot $\left(\mathrm{ft}^{3}\right)$ & 28.32 & cubic decimeter $\left(\mathrm{dm}^{3}\right)$ \\
\hline cubic foot $\left(\mathrm{ft}^{3}\right)$ & 0.02832 & cubic meter $\left(\mathrm{m}^{3}\right)$ \\
\hline acre-foot (acre-ft) & 1,233 & cubic meter $\left(\mathrm{m}^{3}\right)$ \\
\hline acre-foot (acre-ft) & 0.001233 & cubic hectometer $\left(\mathrm{hm}^{3}\right)$ \\
\hline \multicolumn{3}{|c|}{ Flow rate } \\
\hline acre-foot per year (acre-ft/yr) & 1,233 & cubic meter per year $\left(\mathrm{m}^{3} / \mathrm{yr}\right)$ \\
\hline acre-foot per year (acre-ft/yr) & 0.001233 & cubic hectometer per year $\left(\mathrm{hm}^{3} / \mathrm{yr}\right)$ \\
\hline foot per day $(\mathrm{ft} / \mathrm{d})$ & 0.3048 & meter per day $(\mathrm{m} / \mathrm{d})$ \\
\hline cubic foot per second $\left(\mathrm{ft}^{3} / \mathrm{s}\right)$ & 0.02832 & cubic meter per second $\left(\mathrm{m}^{3} / \mathrm{s}\right)$ \\
\hline $\begin{array}{l}\text { cubic foot per day per square foot } \\
\left(\left[\mathrm{ft}^{3} / \mathrm{s}\right] / \mathrm{ft}^{2}\right)\end{array}$ & 0.0348 & $\begin{array}{l}\text { cubic meter per day per square meter }\left(\left[\mathrm{m}^{3} / \mathrm{s}\right] /\right. \\
\left.\mathrm{m}^{2}\right)\end{array}$ \\
\hline cubic foot per day $\left(\mathrm{ft}^{3} / \mathrm{d}\right)$ & 0.02832 & cubic meter per day $\left(\mathrm{m}^{3} / \mathrm{d}\right)$ \\
\hline gallon per minute (gal/min) & 0.06309 & liter per second $(\mathrm{L} / \mathrm{s})$ \\
\hline gallon per day (gal/d) & 0.003785 & cubic meter per day $\left(\mathrm{m}^{3} / \mathrm{d}\right)$ \\
\hline inch per year (in/yr) & 25.4 & millimeter per year $(\mathrm{mm} / \mathrm{yr})$ \\
\hline \multicolumn{3}{|c|}{ Specific capacity } \\
\hline gallon per minute per foot $([\mathrm{gal} / \mathrm{min}] / \mathrm{ft})$ & 0.2070 & liter per second per meter $([\mathrm{L} / \mathrm{s}] / \mathrm{m})$ \\
\hline
\end{tabular}




\begin{tabular}{|c|c|c|}
\hline Multiply & By & To obtain \\
\hline \multicolumn{3}{|c|}{ Hydraulic conductivity } \\
\hline foot per day (ft/d) & 0.3048 & meter per day $(\mathrm{m} / \mathrm{d})$ \\
\hline \multicolumn{3}{|c|}{ Hydraulic gradient } \\
\hline foot per mile ( $\mathrm{ft} / \mathrm{mi})$ & 0.1894 & meter per kilometer $(\mathrm{m} / \mathrm{km})$ \\
\hline \multicolumn{3}{|c|}{ Transmissivity } \\
\hline foot squared per day $\left(\mathrm{ft}^{2} / \mathrm{d}\right)$ & 0.09290 & meter squared per day $\left(\mathrm{m}^{2} / \mathrm{d}\right)$ \\
\hline foot per day per foot $([\mathrm{ft} / \mathrm{d}] / \mathrm{ft})$ & 1 & \\
\hline inch per year per foot $([\mathrm{in} / \mathrm{yr}] / \mathrm{ft})$ & 83.33 & \\
\hline
\end{tabular}

International System of Units to U.S. customary units

\begin{tabular}{|c|c|c|}
\hline Multiply & By & To obtain \\
\hline \multicolumn{3}{|c|}{ Length } \\
\hline meter $(\mathrm{m})$ & 3.281 & foot $(\mathrm{ft})$ \\
\hline meter $(\mathrm{m})$ & 1.094 & yard $(y d)$ \\
\hline micrometer $(\mu \mathrm{m})$ & 0.000039 & inch (in.) \\
\hline \multicolumn{3}{|c|}{ Volume } \\
\hline cubic meter $\left(\mathrm{m}^{3}\right)$ & 6.290 & barrel (petroleum, 1 barrel $=42$ gal) \\
\hline liter $(\mathrm{L})$ & 33.81402 & ounce, fluid (fl. oz) \\
\hline liter (L) & 2.113 & pint $(\mathrm{pt})$ \\
\hline liter $(\mathrm{L})$ & 1.057 & quart (qt) \\
\hline liter $(\mathrm{L})$ & 0.2642 & gallon (gal) \\
\hline cubic meter $\left(\mathrm{m}^{3}\right)$ & 264.2 & gallon (gal) \\
\hline cubic meter $\left(\mathrm{m}^{3}\right)$ & 0.0002642 & million gallons (Mgal) \\
\hline liter (L) & 61.02 & cubic inch $\left(\right.$ in $\left.^{3}\right)$ \\
\hline cubic meter $\left(\mathrm{m}^{3}\right)$ & 35.31 & cubic foot $\left(\mathrm{ft}^{3}\right)$ \\
\hline cubic meter $\left(\mathrm{m}^{3}\right)$ & 1.308 & cubic yard $\left(\mathrm{yd}^{3}\right)$ \\
\hline cubic meter $\left(\mathrm{m}^{3}\right)$ & 0.0008107 & acre-foot (acre-ft) \\
\hline \multicolumn{3}{|c|}{ Flow rate } \\
\hline meter per second $(\mathrm{m} / \mathrm{s})$ & 3.281 & foot per second $(\mathrm{ft} / \mathrm{s})$ \\
\hline \multicolumn{3}{|c|}{ Mass } \\
\hline kilogram (kg) & 2.205 & pound avoirdupois (lb) \\
\hline \multicolumn{3}{|c|}{ Density } \\
\hline kilogram per cubic meter $\left(\mathrm{kg} / \mathrm{m}^{3}\right)$ & 0.06242 & pound per cubic foot $\left(\mathrm{lb} / \mathrm{ft}^{3}\right)$ \\
\hline
\end{tabular}

Temperature in degrees Celsius $\left({ }^{\circ} \mathrm{C}\right)$ may be converted to degrees Fahrenheit $\left({ }^{\circ} \mathrm{F}\right)$ as follows:

${ }^{\circ} \mathrm{F}=\left(1.8 \times{ }^{\circ} \mathrm{C}\right)+32$.

Temperature in degrees Fahrenheit $\left({ }^{\circ} \mathrm{F}\right)$ may be converted to degrees Celsius $\left({ }^{\circ} \mathrm{C}\right)$ as follows:

${ }^{\circ} \mathrm{C}=\left({ }^{\circ} \mathrm{F}-32\right) / 1.8$. 


\section{Datum}

Vertical coordinate information is referenced to the North American Vertical Datum of 1988 (NAVD 88).

Horizontal coordinate information is referenced to the North American Datum of 1983 (NAD 83).

Altitude, as used in this report, refers to distance above the vertical datum.

\section{Supplemental Information}

Concentrations of chemical constituents in water are given either in milligrams per liter ( $\mathrm{mg} / \mathrm{L}$ ) or milliequivalent units per liter (meq/L)

Concentrations of tritium are presented in tritium units (TU)

Relative ages of groundwater are presented in units of years before present (yrs BP)

A value of 9.81 meters per second squared $\left(\mathrm{m} / \mathrm{s}^{2}\right)$ is used for gravity

Carbon-13 data are expressed as ratios in delta notation $\left(\delta^{13} \mathrm{C}\right)$ as parts per thousand (per mil)

Carbon-14 data are expressed as percent modern carbon (pmC)

Data from streambed electrical resistivity instruments are presented as percent relative conductance (PRC) 


\section{Well-Numbering System}

Wells are identified and numbered according to their location in the rectangular system for the subdivision of public lands. Identification consists of the township number, north or south; the range number, east or west; and the section number. Each section is divided into 1640 -acre tracts lettered consecutively (except " $I$ " and " 0 "), beginning with " $A$ " in the northeast corner of the section and progressing in a sinusoidal manner to " $R$ " in the southeast corner. Within the 40 -acre tract, wells are sequentially numbered in the order they are inventoried. The final letter refers to the base line and meridian. In California, there are three base lines and meridians: Humboldt (H), Mount Diablo (M), and San Bernardino (S). All wells in the study area are referenced to the San Bernardino base line and meridian (S). Well numbers consist of 15 characters and follow the format 008N0034W21A001S. In this report, well numbers are abbreviated and written $8 \mathrm{~N} / 34 \mathrm{~W}-21 \mathrm{~A} 1$. The following diagram shows how the number for well $8 \mathrm{~N} / 34 \mathrm{~W}-21 \mathrm{~A} 1$ is derived.

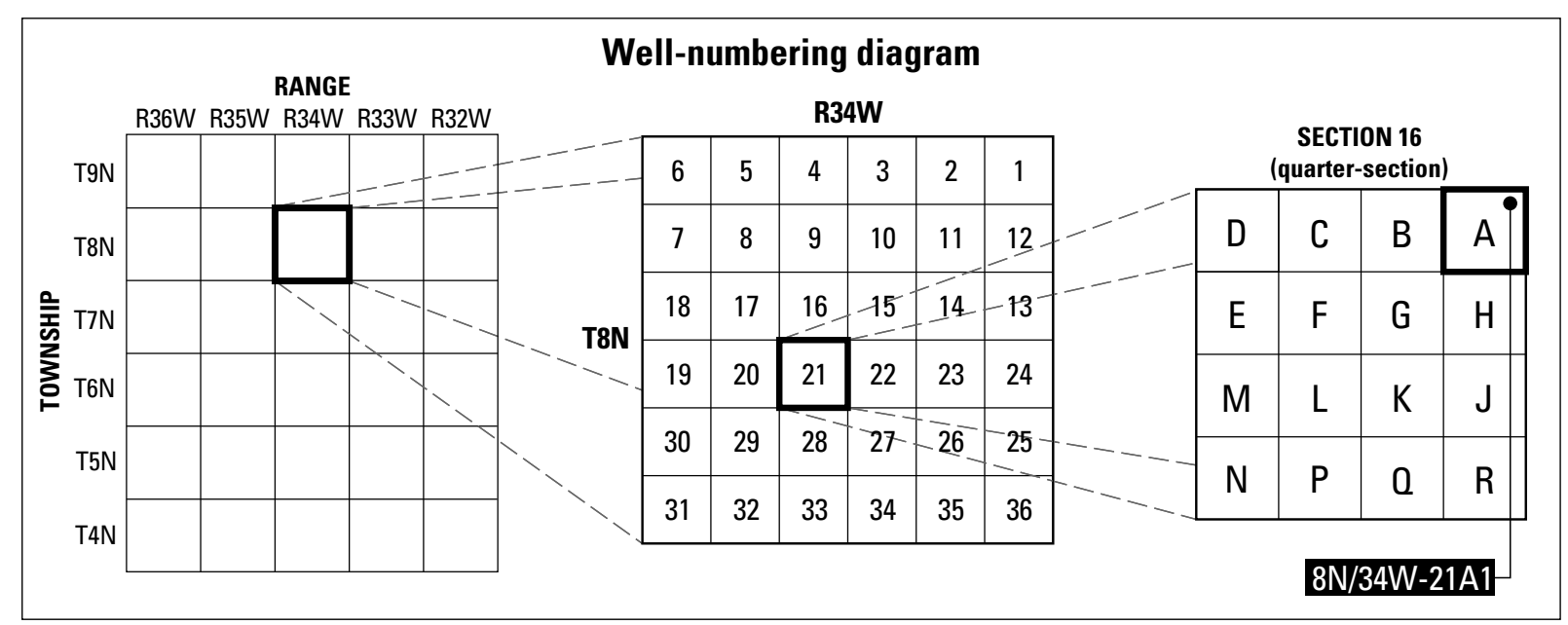




\section{Abbreviations}

$\begin{array}{ll}\text { bls } & \text { below land surface } \\ \text { DWR } & \text { California Department of Water Resources } \\ \text { EPA } & \text { U.S. Environmental Protection Agency } \\ \text { FMMP } & \text { California Department of Conservation, Farmland Mapping \& Monitoring Program } \\ \text { HFM } & \text { hydrogeologic framework model } \\ \text { LANDFIRE } & \text { United States Forest Service Landscape Fire and Resource Management } \\ & \text { Planning Tools } \\ \text { NHD } & \text { National Hydrography Dataset } \\ \text { SACIM } & \text { San Antonio Creek Integrated Model } \\ \text { SACVGB } & \text { San Antonio Creek Valley groundwater basin } \\ \text { SACVW } & \text { San Antonio Creek Valley watershed } \\ \text { SBCWA } & \text { Santa Barbara County Water Agency } \\ \text { SERS } & \text { Streambed electrical resistivity sensor } \\ \text { STIC } & \text { Stream temperature, intermittency, and conductivity instrument } \\ \text { TDS } & \text { Total dissolved solids } \\ \text { USGS } & \text { U.S. Geological Survey } \\ \text { VSFB } & \text { Vandenberg Space Force Base }\end{array}$




\title{
Hydrogeologic Characterization of the San Antonio Creek Valley Watershed, Santa Barbara County, California
}

\author{
By Geoffrey Cromwell, Donald S. Sweetkind, Jill N. Densmore, John A. Engott, Whitney A. Seymour, \\ Joshua D. Larsen, Christopher P. Ely, Christina L. Stamos, Claudia C. Faunt
}

\section{Abstract}

The San Antonio Creek Valley watershed (SACVW) is located in western Santa Barbara County, about 15 miles south of Santa Maria and 55 miles north of Santa Barbara, California. The SACVW is about 135 square miles and encompasses the San Antonio Creek Valley groundwater basin; the SACVW is separated from adjacent groundwater basins by the Casmalia and Solomon Hills to the north, and the Purisima Hills to the south. At the western, downstream part of the valley, uplifted, consolidated rocks cause groundwater to discharge at land surface at Barka Slough. Since the late 1800 s, groundwater has been the primary source of water for agricultural, military, municipal, and domestic uses. Groundwater withdrawal by pumping exceeded the amount of water replenishing the aquifer system during water years 1948-2018, causing groundwater-level declines of more than 150 feet in parts of the valley and reducing base flow at Barka Slough. Reliance on groundwater for agricultural water use (primarily for the irrigation and frost protection of vineyards, and fruit and berry crops) continues to strain the sustainability of the groundwater system.

Through a cooperative agreement, the Santa Barbara County Water Agency and Vandenberg Space Force Base invited the U.S. Geological Survey to address declines in groundwater levels, develop a better understanding of the hydrogeologic system, and provide tools to help evaluate and manage the effects of future development of the San Antonio Creek Valley groundwater basin within the encompassing San Antonio Creek Valley watershed (SACVW). The objectives of this study were to (1) refine the hydrogeologic framework of the San Antonio Creek Valley watershed, (2) quantify the hydrologic budget of the valley, and (3) develop hydrologic modeling tools to evaluate and aid in managing the groundwater resource. This report focuses on the first and second objectives to construct a hydrogeologic framework and characterize the historical and present-day hydrologic conditions of the SACVW during water years 1948-2018. As part of the second objective, work included quantifying the hydrologic budget and evaluating the hydrogeologic system using a combination of existing data and geologic and hydrologic data collected for this study.
The groundwater-flow system in the SACVW consists of five hydrogeologic units. These separate water-bearing units were identified based on hydrogeologic properties, such as sediment grain size, vertical-head differences in multiple-depth, monitoring-well sites, long-term groundwater level responses to pumping and climate, and the chemical character of groundwater and groundwater age in the mostly semi-consolidated to unconsolidated basin-fill sediments. The hydrogeologic units that comprise the different aquifers vary in their lithologic composition. The upper and lower aquifers (upper Paso Robles Formation, and lower Paso Robles Formation and Careaga Sandstone, respectively) are relatively coarse grained and are comprised of sand, gravel, and clay; the middle confining unit (the middle Paso Robles Formation) is relatively fine grained and is comprised of primarily clay, silt, and sand. The Pezzoni-Casmalia and Los Alamos faults, which are inferred to transect the SACVW between the western and eastern areas of the valley floor, do not appear to substantially affect the groundwater system.

Present-day recharge to the study area occurs primarily as infiltration from precipitation and streams in the upland areas of the Casmalia Hills and Solomon Hills, and along the main channel of San Antonio Creek. Reported estimates of annual natural recharge during water years 1948-2018 generally ranged from about 5,000 acre-feet to more than about 30,000 acre-feet. Stable and radioactive isotopes show that groundwater from the lower aquifer is old and probably was recharged as infiltration from precipitation and streams in the eastern upland areas of the Solomon Hills; however, the infiltration and recharge from these sources probably does not occur under present-day climatic conditions. Anthropogenic recharge, from sources such as return flow from agricultural irrigation, municipal water systems, and wastewater effluent, was estimated to range from about 600 acre-feet in 1948 to about 6,600 acre-feet in 2018. The average annual amount of groundwater removed from the SACVW by pumping during 1948-2018 was estimated to be about 17,200 acre-feet per year, increasing from about 3,000 acre-feet in 1948 to about 32,600 acre-feet in 2018. Estimates of annual pumpage generally exceeded estimates of annual recharge beginning in the mid-1970s and continuing through 2018. The predominant direction of groundwater flow under historical and present-day 
conditions was from the eastern uplands in the Solomon Hills to the west along San Antonio Creek to the discharge area in Barka Slough, and from the northern uplands in the Casmalia Hills south to San Antonio Creek.

Pumpage since the early 1900 s and the subsequent groundwater-level declines have substantially reduced the amount of natural groundwater discharge at Barka Slough. Estimates of base flow to San Antonio Creek at the western, downstream extent of the SACVW have varied over time in response to changes in groundwater pumpage and climate; however, there was an overall decline in base flow during water years 1956-2018, decreasing from an average of about 1,700 acre-feet per year during 1956-69, to about 300 acre-feet per year during 2016-18. The long-term extraction of groundwater correlates with a decrease in groundwater levels by more than about 150 feet since the early 1940s in the eastern part of the basin near Los Alamos, and as much as about 50 feet in the upland areas and in the western part of the basin. At Barka Slough, groundwater levels have declined below land surface in some places, altering native riparian vegetation in and around the slough.

Surface-water quality in the SACVW varied depending on location and the time of year the samples were collected and on the amount of annual precipitation Most groundwater in the SACVW was calcium-bicarbonate-type water with total dissolved-solids concentrations of about 500-800 milligrams per liter generally representing water naturally recharged as infiltration from precipitation and streams. Total dissolved-solids concentrations in some wells ranged from 800 to 8,000 milligrams per liter, suggesting mixing of naturally recharged infiltrated water with water associated with oil-bearing geologic formations, agricultural products, or the evaporation of shallow groundwater. Concentrations of total dissolved solids and the chemical constituents chloride, nitrate plus nitrite (as nitrogen), calcium, and magnesium at selected wells generally increased during water years 1980-2018; increasing concentrations of these constituents may be associated with the expansion of agriculture in the watershed over time and the corresponding increase in the use of nitrates and calcium- and magnesium-based fertilizers and soil additives in modern agricultural practices.

The predominant direction of groundwater flow during historical and present-day conditions was from the eastern uplands in the Solomon Hills to the west along San Antonio Creek toward Barka Slough, and from the western uplands in the Casmalia Hills south to San Antonio Creek. The age of groundwater in the SACVW was evaluated using radioactive isotopes, and the flow of groundwater within the SACVW was evaluated using radioactive and stable isotopes. Modern groundwater (recharged after 1952) was generally found adjacent to San Antonio Creek and its tributaries in wells with perforated depths that averaged about 270 feet below land surface. Pre-modern groundwater (recharged before 1952) was found in wells that had average perforation depths of about $540 \mathrm{ft}$ below land surface. Pre-modern groundwater identified in wells in the eastern upland area is interpreted to have had long, slow travel times to the western part of the SACVW where it was eventually discharged as base flow at Barka Slough or extracted as groundwater pumpage.

\section{Introduction}

Groundwater is the primary source of water supply in the San Antonio Creek Valley groundwater basin (SACVGB). The SACVGB is in western Santa Barbara County about 15 miles (mi) south of Santa Maria and 55 mi northwest of Santa Barbara (fig. 1). Groundwater in the SACVGB is an important source of water for Vandenberg Space Force Base (VSFB), the town of Los Alamos, and irrigated agriculture. Groundwater is also the source of water for Barka Slough (Martin, 1985), which provides important habitat for several endangered species (Descheneaux, 1975; California Department of Fish and Wildlife, 2021). Residents and water managers are concerned that if the groundwater withdrawals continue, groundwater levels will decline to a point where it will be uneconomical to produce water. In addition, water managers are concerned that water quality may deteriorate due to pumping from deeper aquifer units with poorer quality water as a result of dewatering of the alluvial aquifer deposits.

Previous studies have indicated that by the 1980s, groundwater pumpage in the SACVGB was already greater than perennial base flow in San Antonio Creek (Muir, 1964; Hutchinson, 1980; Martin, 1985). Further declines in groundwater levels in wells and corresponding reductions in base flow to San Antonio Creek will likely affect all users in the SACVGB and will affect the viability of several endangered species and their habitats in Barka Slough. Furthermore, the SACVGB was designated a "medium priority" groundwater basin by the California Department of Water Resources (DWR) as part of the Sustainable Groundwater Management Act (SGMA) that was enacted in 2014. As a result of this designation, stakeholders were required to develop a groundwater sustainability plan with the goal of balancing groundwater withdrawals and recharge in order to prevent further losses of groundwater storage. Defining the quantity and quality of the groundwater supply and establishing tools to allow users to efficiently and sustainably utilize the available groundwater resources will help resource managers plan for anticipated growth and future water use in the SACVGB. 

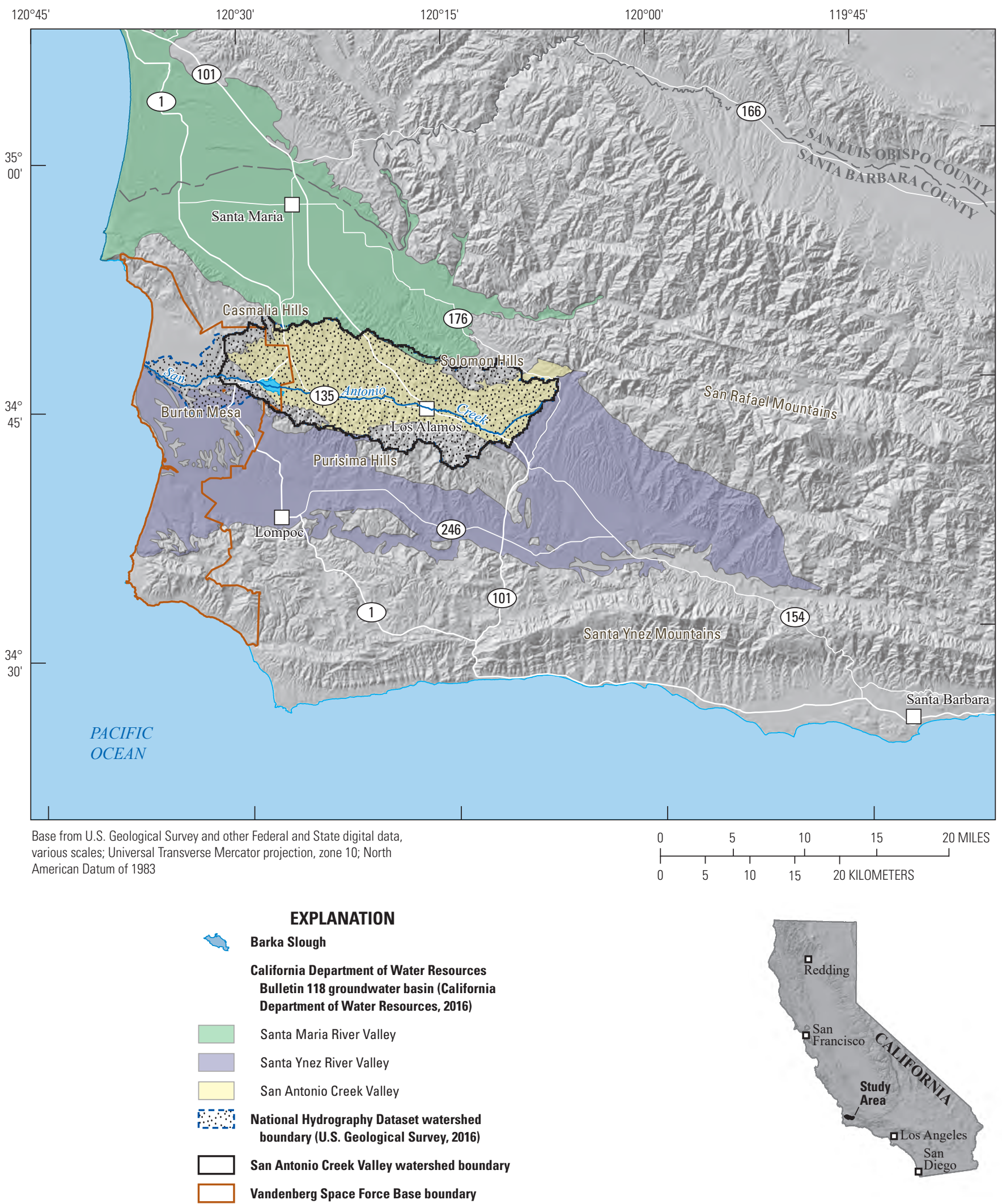

Figure 1. Location of the San Antonio Creek Valley groundwater basin and the San Antonio Creek Valley watershed, Santa Barbara County, California. 
To better manage water resources in the SACVGB, the Santa Barbara County Water Agency (SBCWA), VSFB, and the U.S. Geological Survey (USGS) initiated a cooperative study to understand the hydrogeologic system of the SACVGB and in the encompassing San Antonio Creek Valley watershed (SACVW; figs. 1, 2). The numerical San Antonio Creek Valley Integrated Hydrological Model (SACIM) also was developed to simulate the integrated surface-water and groundwater systems in the SACVW, including natural and anthropogenic (that is, originating from human activity) recharge and discharge throughout the study area during water years 1948-2018 (Woolfenden and others, 2022). This report describes the historical hydrologic and hydrogeologic conditions of the SACVW during water years 1948-2018. Unless specified otherwise, all listed years in this report are water years; a water year is the one-year period from October 1 to September 30 and is designated by the year in which the period ends.

\section{Purpose and Scope}

The purpose of this report is to quantify and characterize the historical hydrologic and hydrogeologic conditions in the SACVGB from 1948 to 2018 that inform the development of an integrated hydrological model (Woolfenden and others, 2022). Hydrologic and hydrogeologic data were compiled from existing databases and published reports and were supplemented with new data collected as part of this study to evaluate the aquifer system and better understand changes in the hydrologic and hydrogeologic conditions of the area. Information presented in this report includes precipitation and streamflow records, changes in land use during the study period, surface and subsurface hydrogeologic data, results from instruments designed to characterize surface water/ groundwater interactions, groundwater-level measurements (existing and new), and groundwater-quality data (existing and new). This report provides analysis and synthesis of these data and information and characterizes the SACVGB aquifer system.

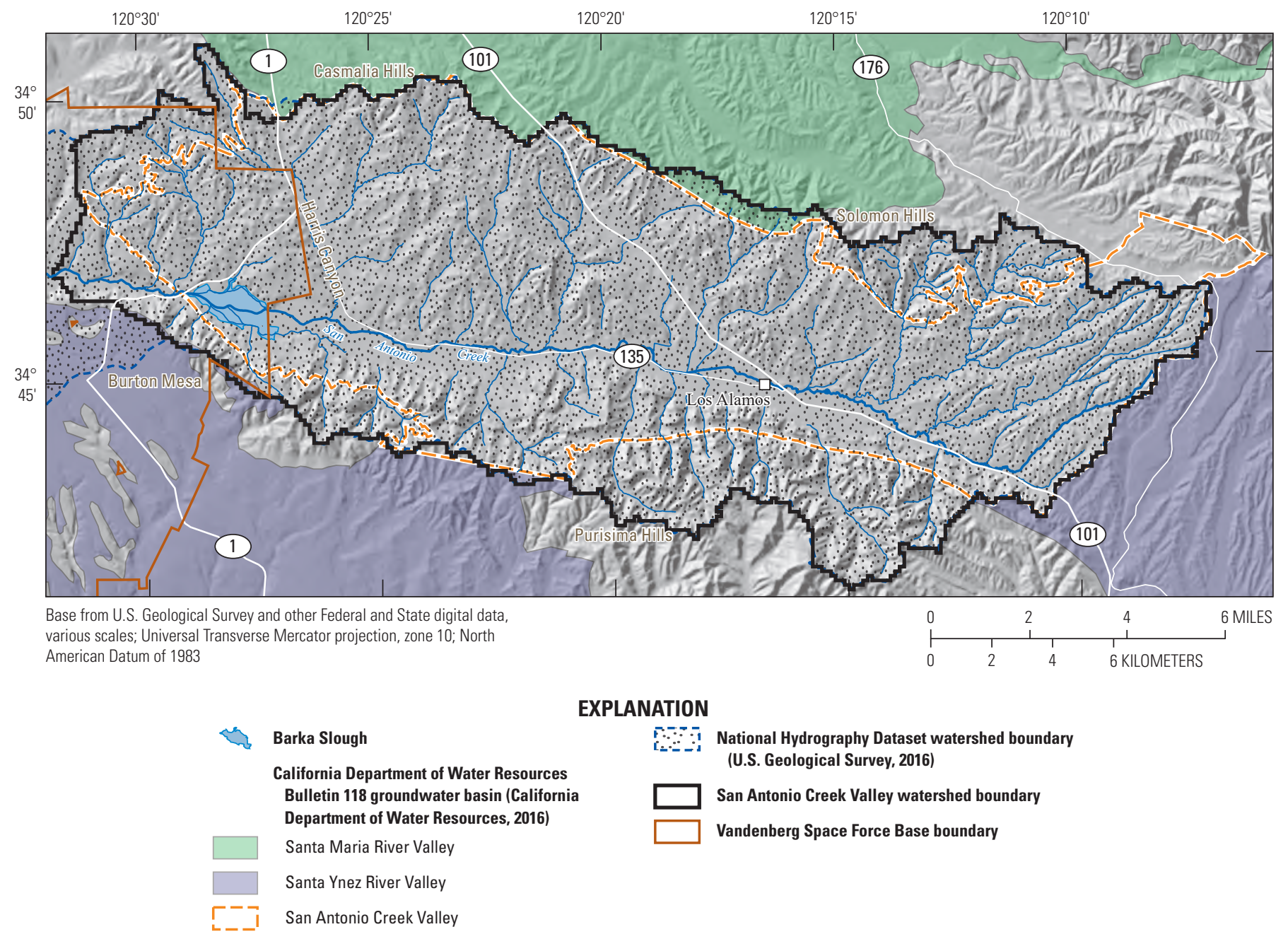

Figure 2. San Antonio Creek Valley groundwater basin and the San Antonio Creek Valley watershed, Santa Barbara County, California. 


\section{Previous Investigations}

Previous investigations of the SACVGB focused on the geology or hydrology of the valley and northwestern Santa Barbara County, and were often performed with the purpose of characterizing the geology of nearby oil fields. These previous studies provided local and regional context of the geologic and hydrology of basin.

The geology of the SACVGB was described by Dibblee (1950), Woodring and Bramlette (1950), and Muir (1964). Dibblee (1950; scale 1:62,500) mapped the geology of the southern part of the SACVGB as part of a broader investigation to map and characterize the southwestern district of Santa Barbara County. Woodring and Bramlette (1950; scale 1:24,000) described the stratigraphy, lithology, and paleontology of the Mesozoic bedrock and Cenozoic sedimentary rocks of the Santa Maria area, including the SACVGB, and applied geologic and structural overlays to aerial photographs. Muir (1964) focused specifically on the geology and groundwater of the SACVGB. As part of this work, Muir (1964; scale 1:48,000) refined the geologic mapping of Woodring and Bramlette (1950) and described the hydrogeologic characteristics of the Cenozoic sedimentary rocks within the SACVGB. Geologic maps at 1:24,000 scale of the six quadrangles that comprise the SACVGB were published by Dibblee and Ehrenspeck (1988, 1989, 1993a, b) and Dibblee and others (1994a, b). Preliminary geologic maps of the Santa Maria 30-minute x 60-minute quadrangle (which includes the SACVGB) were compiled by Tennyson (1992), and Tennyson and others (1995; scale 1:100,000). These preliminary geologic maps were superseded by geologic and geophysical maps of the Santa Maria and part of the Point Conception 30-minute x 60-minute quadrangle by Sweetkind and others (2021; scale 1:100,000). Namson and Davis (1990) characterized the late Cenozoic deformation and the tectonic history of the southern California Coast Ranges (San Rafael Mountains; fig. 1) and presented geologic cross-sections that helped define the structural and stratigraphic relations of the greater SACVGB area (discussed later in the "Geology and Structure" section). Studies of the geology and petroleum resources of the area include Jenkins (1943), American Association of Petroleum Geologists (1959), Crawford (1971), California Division of Oil, Gas and Geothermal Resources (1982), Issacs (1992), Stanley and others (1996), Miller and Meltzer (2002), California Department of Conservation (2008), and Sweetkind and others (2010).

Early hydrologic evaluations specific to the SACVGB were performed by Muir (1964), Lafreniere and French (1968), Hutchinson (1980), Mallory (1980), Martin (1985) and Bright and others (1997). Muir (1964) provided the first assessment of hydrologic and hydrogeologic conditions in the SACVGB, including assessments of water quality. Hutchinson (1980) provided a temporal update to the hydrologic and hydrogeologic work of Muir (1964) and evaluated relations between agricultural pumping and base flow in San Antonio
Creek. Mallory (1980) studied the effects of increasing groundwater pumpage on water supply in Barka Slough. Martin (1985) developed the first numerical groundwater flow model of the SACVGB; a two-dimensional model that simulated transient conditions in the basin during calendar years 1944-77. More recent studies by Tetra Tech, Inc. (2012, 2013) provided temporal updates on the hydrologic and hydrogeologic conditions of the basin through 2010. Tetra Tech, Inc. (2012) evaluated the hydrologic conditions and historical water balance in the SACVGB during water years 1935-2010, and Tetra Tech, Inc. (2013) developed a numerical groundwater flow model based on the work of Tetra Tech, Inc. (2012). Additional hydrologic reports focused on the collection and analysis of groundwater-level and water-quality data, including California Department of Water Resources (1971), Mathany and others (2010), Burton and Belitz (2013), and Burton and others (2013).

\section{Description of the Study Area}

The SACVGB is defined by the DWR Bulletin 118 (California Department of Water Resources, 2016) and encompasses an area of about $105 \mathrm{mi}^{2}$. The basin is bounded on the north by the Casmalia Hills and the Solomon Hills, on the east by a watershed divide, on the south by the Purisima Hills and Burton Mesa, and on the west by uplifted consolidated sedimentary rocks that form the western boundary of Barka Slough (figs. 1, 2). San Antonio Creek and its tributaries provide the main surface drainage for the SACVGB. San Antonio Creek originates at the eastern part of the SACVGB and flows west along the valley floor (fig. 2); San Antonio Creek flows into the Pacific Ocean about five miles east of the SACVGB (fig. 1). Tributaries that originate in the Casmalia Hills and Solomon Hills flow south into San Antonio Creek, and tributaries that originate in the Purisima Hills and Burton Mesa flow north into San Antonio Creek (fig. 2). The general direction of groundwater flow in the SACVGB matches the direction of surface water flow; groundwater generally flows from the upland hills toward San Antonio Creek on the valley floor and then along the valley floor from east to west toward the Pacific Ocean (Muir, 1964; Hutchinson, 1980; Martin, 1985).

At the western end of the groundwater basin, consolidated rocks near land surface form a barrier to the seaward flow of groundwater; groundwater upwelling east of the barrier has created a 660-acre marshland known as Barka Slough (fig. 1). Barka slough is one of the few pristine marshlands in southern California and historically is known to have been inhabited by several threatened or endangered species of wildlife (Descheneaux, 1975; California Department of Fish and Wildlife, 2021), including the California Red-legged Frog (Rana draytonii), the unarmored threespine stickleback (Gasterosteus aculeatus). 
Groundwater basins designations are largely based on local hydrogeologic conditions but are also subject to geographic and political considerations; therefore, specific groundwater basin boundaries do not always encompass the entirety of the local hydrologic system. The SACVGB is the focus of this study because of specific stakeholder interests, however, the SACVW was used as the study area and active domain of the numerical SACIM (Woolfenden and others, 2022) because the SACVW comprises parts of the San Antonio Creek watershed that encompass most of the SACVGB (USGS National Hydrography Dataset [NHD] Hydrologic Unit 10-1806000901; U.S. Geological Survey, 2016). Using the SACVW as the study area ensures that estimates of recharge and discharge are representative of the SACVGB. The SACVW has an area of about 135 square miles $\left(\mathrm{mi}^{2}\right)$, about $30 \mathrm{mi}^{2}$ larger than the SACVGB, which has an area of about $105 \mathrm{mi}^{2}$. The northeastern-most part of the SACVGB is excluded from the SACVW because it lies outside the local watershed boundary (fig. 2).

\section{Climate}

The SACVW has a semiarid climate characterized by a wet season and dry season. Mean monthly precipitation in the town of Los Alamos ranges from about 0.02 inches in July to about 3.2 inches (in.) in February (fig. 3; Western Regional Climate Center, 2020). About 92 percent of annual precipitation recorded in Los Alamos during 1948-2018 falls during the wet season from November to April (fig. 3; Santa Barbara County, 2019), and the mean annual precipitation recorded in Los Alamos during 1948-2018 was $15.2 \mathrm{in} / \mathrm{yr}$ (fig. 4; climate station 204, Los Alamos Fire Station \#24; Santa Barbara County, 2019). Interannual variation of precipitation is large (fig. 4) and follows natural cycles and trends in global circulation patterns that tend to favor formation of atmospheric rivers (Zhu and Newell, 1998). Atmospheric rivers are regions of the lower atmosphere characterized by strong winds and large water-vapor content that commonly produce heavy rainfall during the wet season (Ralph and others, 2013). About 40 percent of annual precipitation in the SACVW can be attributed to atmospheric river events (Dettinger, 2011). In figure 4, average, wet, and dry precipitation years were classified based on the percentage of annual precipitation relative to the long-term mean precipitation (following the work of Hutchinson, 1980) for 1948 to 2018 (15.2 in/yr). Average years had precipitation within plus or minus 25 percent of the long-term mean, between 11.4 and $19.0 \mathrm{in} / \mathrm{yr}$. Wet years had precipitation greater than $19.0 \mathrm{in} / \mathrm{yr}$, and dry years had precipitation less than $11.4 \mathrm{in} / \mathrm{yr}$. The spatial distribution of precipitation varies across the study area (fig. 5). Mean annual precipitation during calendar years 1981-2010 generally is lower in the western part of the SACVW (about $15 \mathrm{in} / \mathrm{yr}$ ) and higher in the Solomon Hills and eastern upland areas (about 22 in/yr; fig. 5; PRISM Climate Group, 2013).

Mean temperatures in the SACVW vary according to season, proximity to the coast, and elevation. Maritime influence is more evident in the western part of the valley and is responsible for frequent fog events and high humidity that moderate summertime maximum temperatures. During calendar year 1981-2010, July mean maximum temperatures ranged from about 60 degrees Fahrenheit $\left({ }^{\circ} \mathrm{F}\right)$ in the western part of the SACVW to about $88^{\circ} \mathrm{F}$ in the eastern part (PRISM Climate Group, 2013). Summertime mean minimum temperatures were more uniform across the SACVW and were generally between 50 and $60^{\circ} \mathrm{F}$ during July. Mean maximum January temperatures did not vary considerably across the watershed and were generally between 60 and $70{ }^{\circ} \mathrm{F}$. Mean minimum January temperatures generally were warmer in the hills surrounding the valley than on the valley floor-a condition known as a temperature inversion. January mean minimum temperatures were about 45 to $50^{\circ} \mathrm{F}$ in the upland areas of the Casmalia Hills, Solomon Hills, and Purisima Hills, and about 35 to $40^{\circ} \mathrm{F}$ on the valley floor along San Antonio Creek.

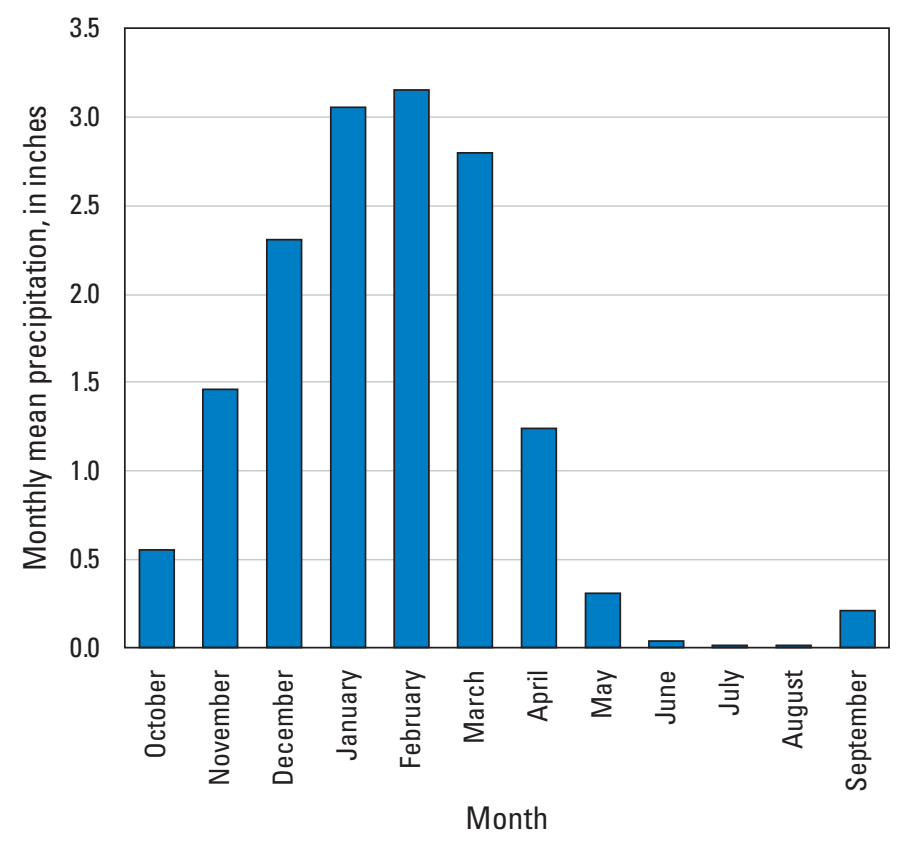

Figure 3. Mean monthly precipitation during water years 1948 to 2018, San Antonio Creek Valley watershed, Santa Barbara, California (Western Regional Climate Center, 2020). 


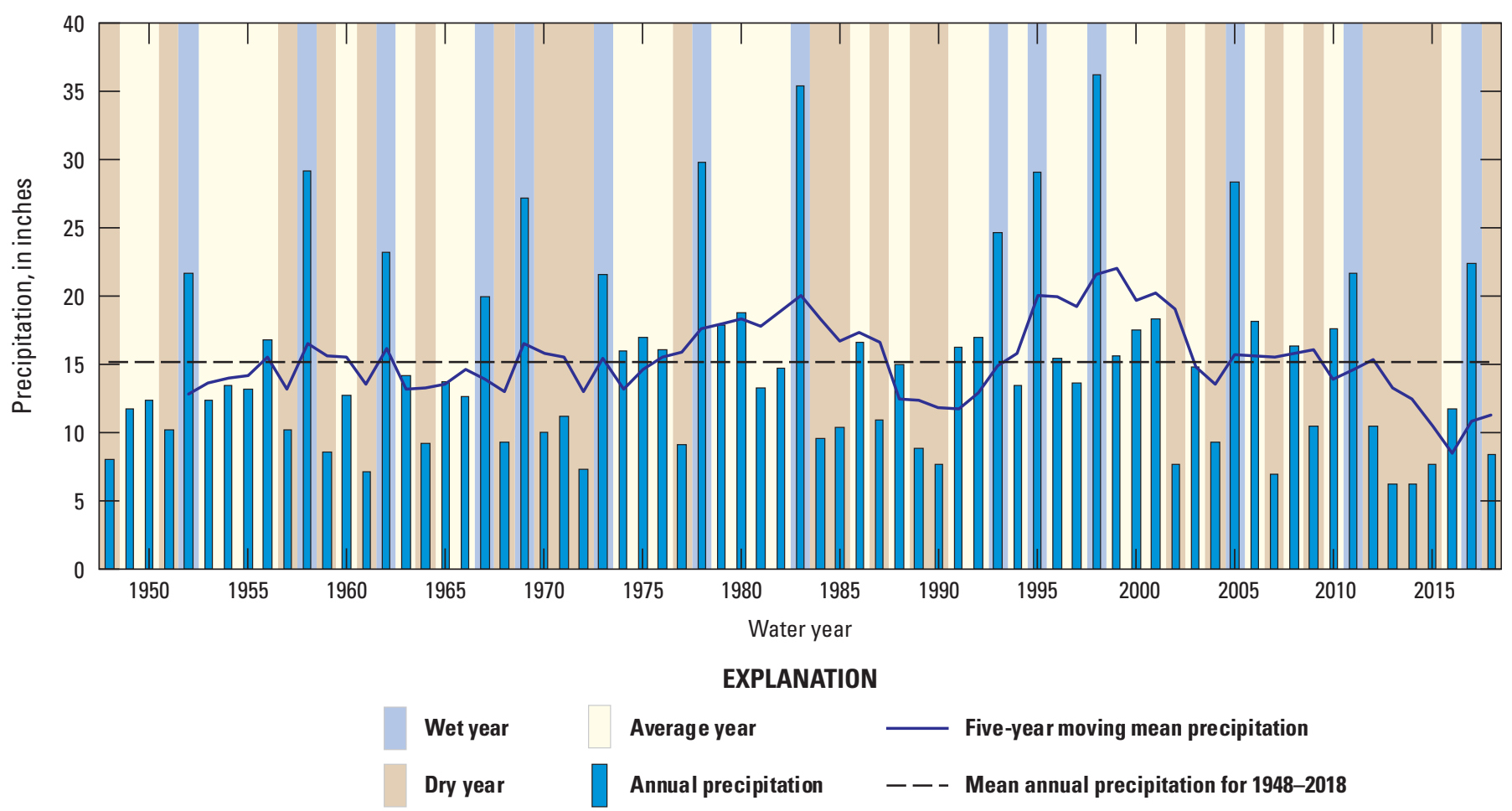

Figure 4. Annual precipitation during water years 1948-2018, San Antonio Creek Valley watershed, Santa Barbara, California (Santa Barbara County, 2019). Average years had annual precipitation between 11.4 and $19.0 \mathrm{in} / \mathrm{yr}$, wet years had precipitation greater than 19.0 in/yr, and dry years had precipitation less than 11.4 in/yr.

\section{Land Use}

Land in the SACVW has been used primarily for agriculture. Historically, the upland parts of the valley have been used for dry farming or pastureland, and the valley floor along San Antonio Creek and its tributaries was used for irrigated farming. However, large sections of formerly non-irrigated pastureland in the uplands were converted to irrigated vineyards between 1977 and 1986 (figs. 6, 7). The western quarter of the valley is owned by VSFB, and the remainder of the valley is privately owned. The town of Los Alamos is a census-designated place (U.S. Census Bureau, 2020), and has experienced a slow, steady growth in population over about the last one hundred years, ranging from about 140 people in 1935 (Tetra Tech, Inc., 2012) to 900 people in 1977 (Hutchinson, 1980, citing Los Alamos Community Services District, oral commun., 1977), 1,372 people in 2000 (U.S. Census Bureau, 2000), 1,890 people in 2010 (U.S. Census Bureau, 2010), and to 1,839 people in 2020 (U.S. Census Bureau, 2020; table 1.1). For 2018, the population of Los Alamos was estimated to be 1,850 people (see appendix 1; table 1.1)

The total population of the SACVW includes residents who live in the town of Los Alamos and rural residents who live outside the town but within the SACVW. Estimates of population of the SACVW were 1,921, 2,646, and 2,575 people for 2000, 2010, and 2020, respectively (table 1.1). For these three years, the estimated population of the SACVW was, on average, 1.4 times the population of the town of Los Alamos-based on this multiplier, the population of the SACVW for 2018 was estimated to be 2,590 people (appendix 1; table 1.1).

Land-use data from DWR (California Department of Water Resources, 1959, 1968, 1977, 2000) and the Farmland Mapping \& Monitoring Program (FMMP; California Department of Conservation, 2018) were used to quantify agricultural and developed acreage in the SACVW. Land-use maps of the SACVW were compiled for 1959, 1968, 1977, 1986, 1996, 2006, and 2016 in a geographic information system (GIS) database (figs. 6, 7), using data from DWR, the FMMP, and the U.S. Forest Service Landscape Fire and Resource Management Planning Tools (LANDFIRE; LANDFIRE, 2014; table 1); land-use classifications for these years were used in the numerical SACIM (Woolfenden and others, 2022). Land not classified as agricultural or developed in these data sources was assumed to be native vegetation and assigned native vegetation land-use codes according to the LANDFIRE version 140 classification for 2014 (LANDFIRE 140; LANDFIRE, 2014) to better classify the distribution of native plants. If the original sources classified an area of land as native vegetation, and LANDFIRE 140 classified the same area of land as agriculture, then the California Mesic Chaparral native vegetation code was applied (table 1), except for 2016 for which the LANDFIRE 140 codes were used to 


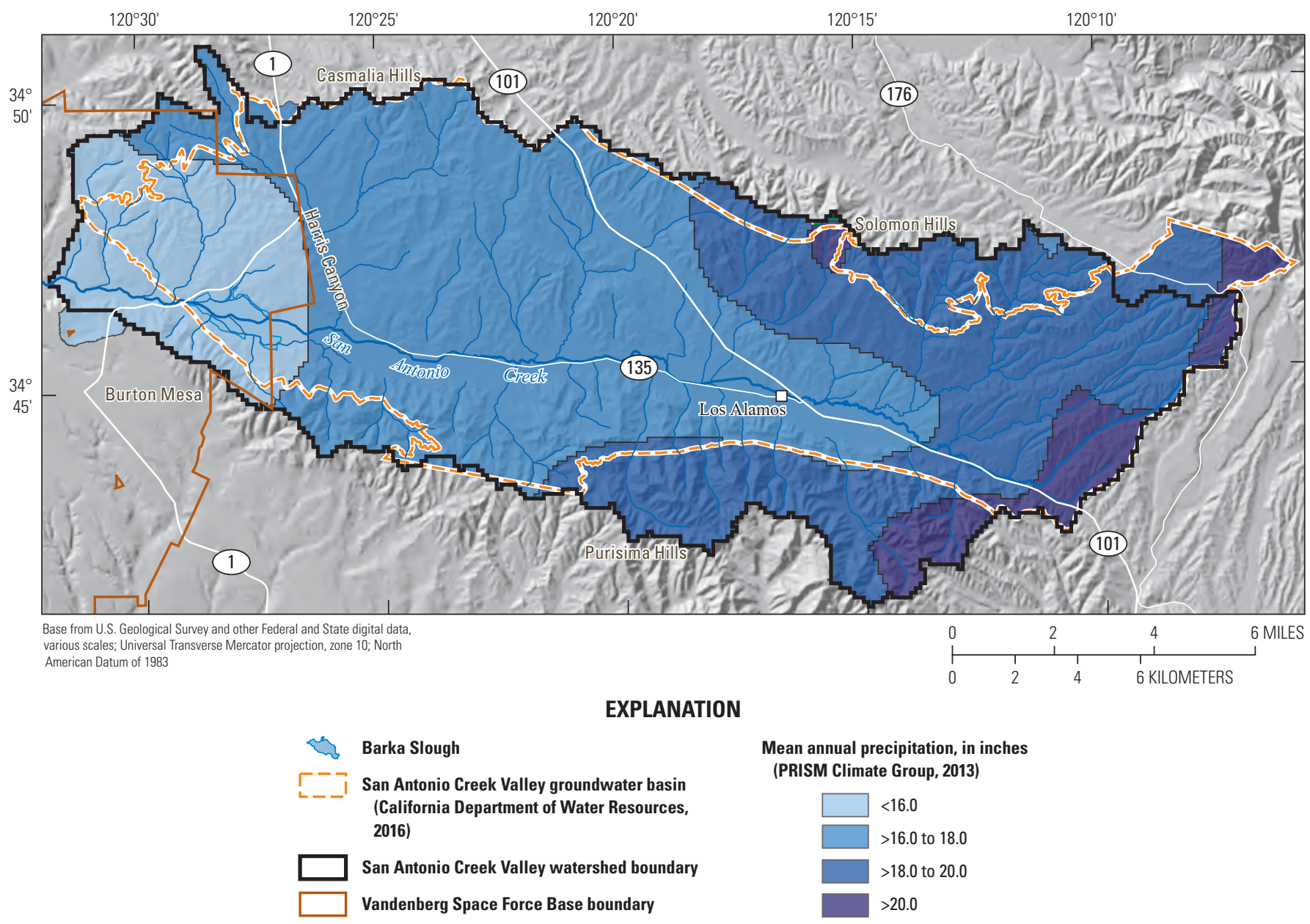

Figure 5. Contours of mean annual precipitation during calendar years 1981-2010 (PRISM Climate Group, 2013), San Antonio Creek Valley watershed, Santa Barbara, California.

classify the entire year. If an area of land was not classified as agricultural or developed in the original sources, the LANDFIRE 140 classifications for native vegetation (table 1) were assigned to that area of land. . Land classified as roads in LANDFIRE 140 was assigned as 'Developed' for all land-use years (table 1).

Land-use data from DWR for USGS 7.5-minute topographic quadrangles (Careaga Canyon, Casmalia, Foxen Canyon, Lompoc, Los Alamos, Los Olivos, Orcutt, Sisquoc, and Zaca Creek) were compiled for 1959, 1968, 1977, and 1996 (California Department of Water Resources, 1959, 1968, 1977, 2000). Unfortunately, not all quadrangles were available for each of these years, resulting in some gaps in data. For years with missing data, agricultural land-use data from the next available land-use year was used. For 1959, data were missing from the Lompoc and Zaca Creek quadrangle, as a result data from the 1968 land-use map were used for the Lompoc quadrangle, and data from the 1996 and 2016 land-use maps were used for the Zaca Creek quadrangle.
For 1968 and 1977, data were missing from the Zaca Creek quadrangle, as a result data from the 1996 and 2016 land-use maps were also used for the Zaca Creek quadrangle.

Land-use data from FMMP were compiled for 1986, 2006, and 2016 (California Department of Conservation, 2018). Areas defined as any type of farmland were refined using historical satellite imagery from Google Earth (imagery dates December 30, 1986; variously dated, 2006; and variously dated, 2016: Google, Landsat/Copernicus, accessed November 2018), DWR land-use maps for 1977 and 1996, and Agricultural Field Boundaries for 2016 (Santa Barbara County, 2017).

All land-use classes for the seven years with land-use data were assigned LANDFIRE 140 codes and grouped into one of three general categories: developed, agriculture, and native vegetation (table 2). Agricultural land use was further sub-categorized (figs. 6, 7; tables 1,2). The LANDFIRE 140 dataset lacked a category for field crops, which were commonly identified in the other land-use sources; therefore, agriculture classified as field crops in the original sources were grouped with row crops for this study. 


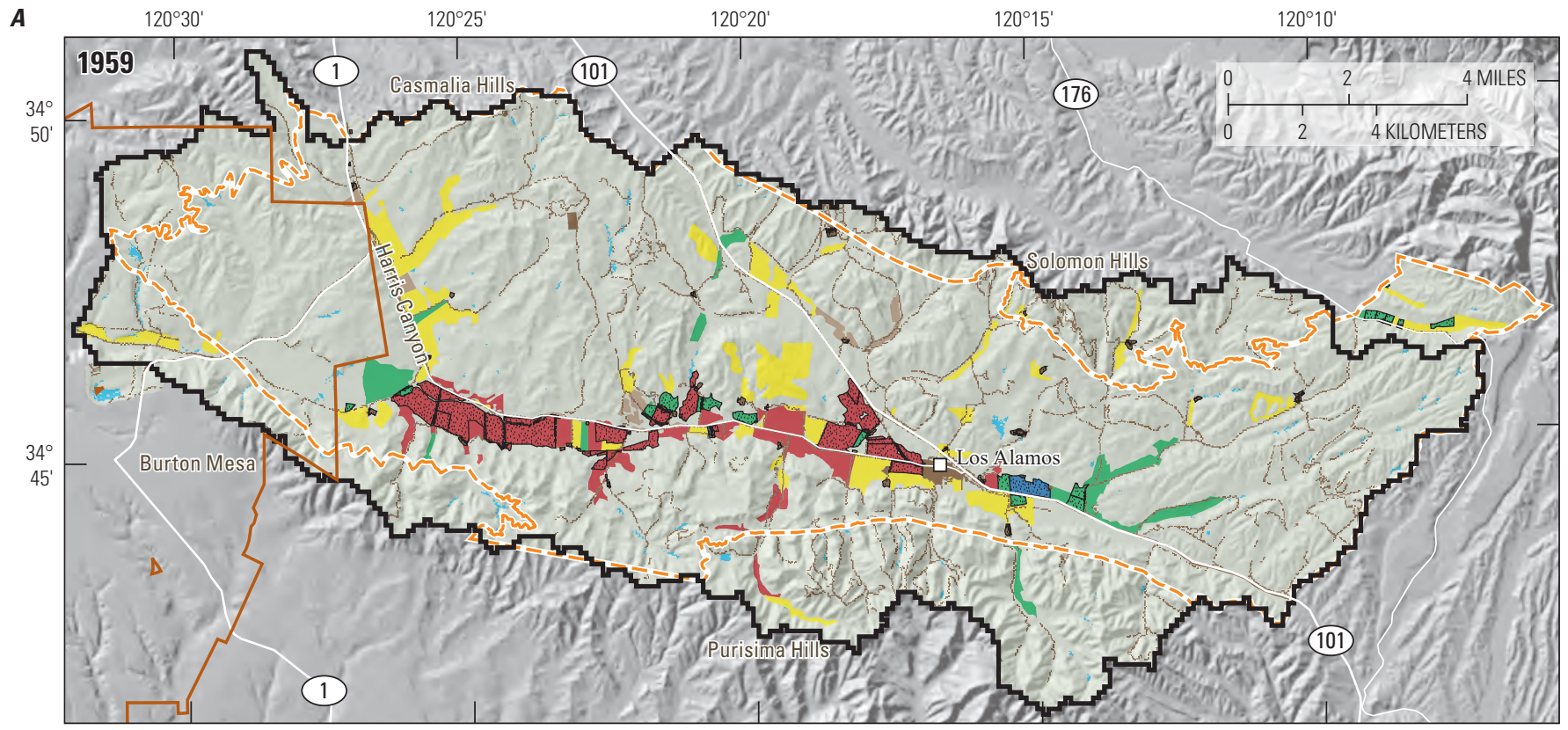

Base from U.S. Geological Survey and other Federal and State digital data, various scales;

Universal Transverse Mercator projection, zone 10; North American Datum of 1983

B

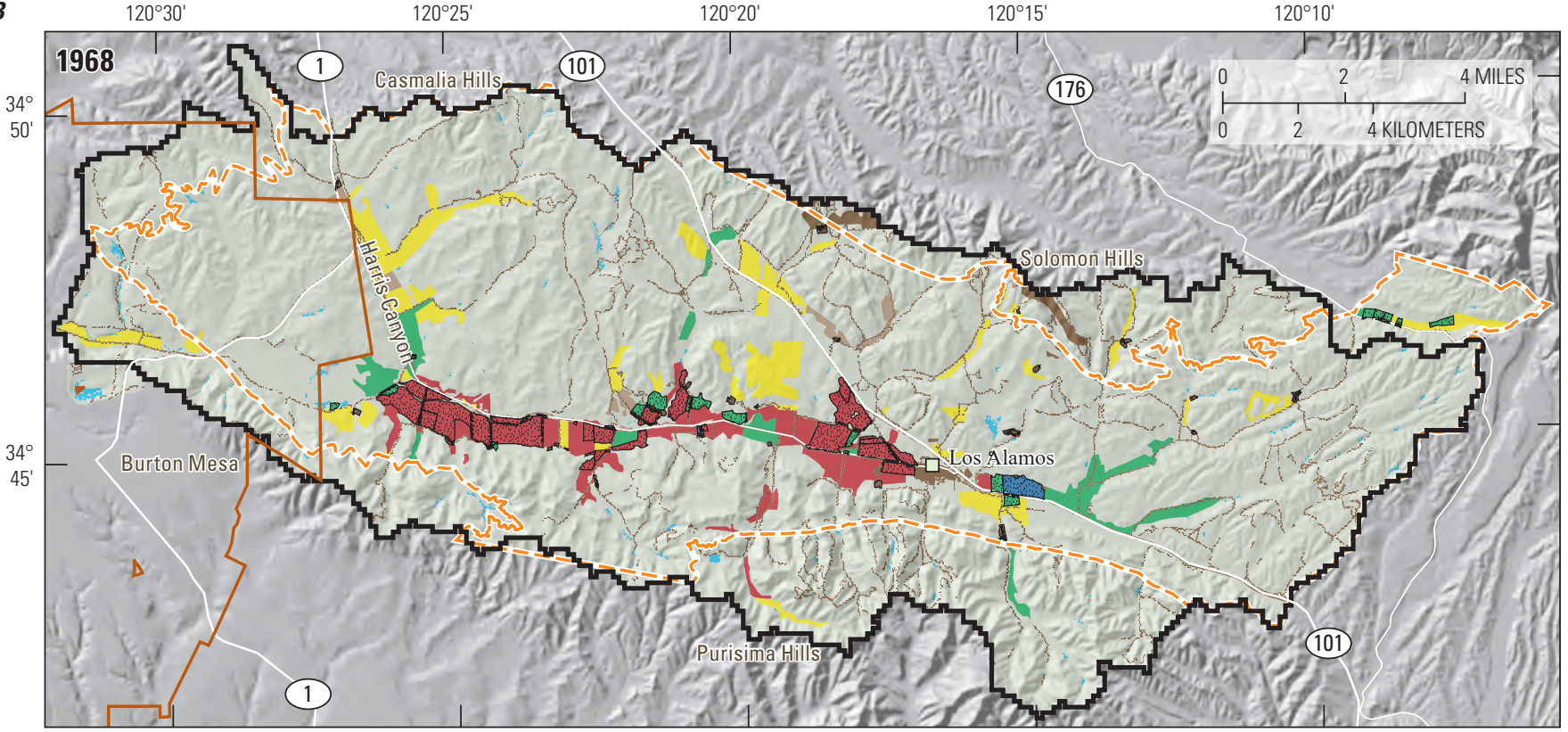

Base from U.S. Geological Survey and other Federal and State digital data, various scales;

Universal Transverse Mercator projection, zone 10; North American Datum of 1983
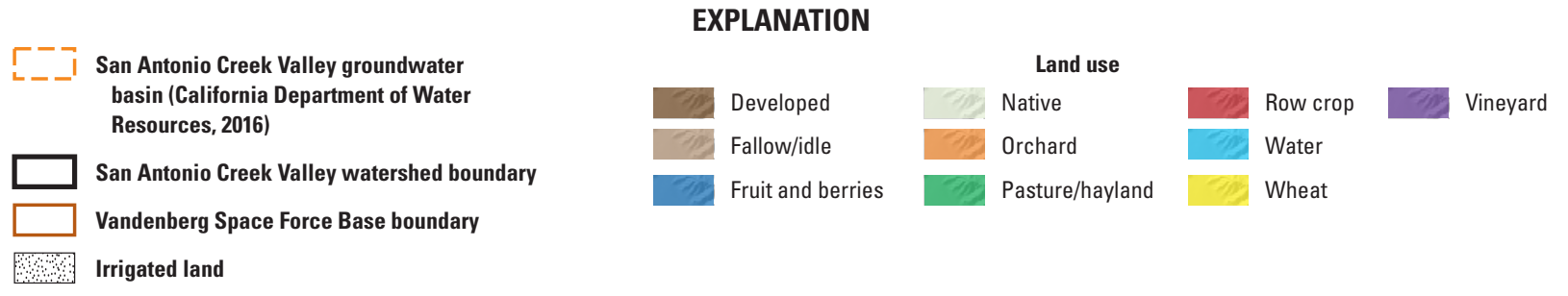

Figure 6. Land-use maps for selected years, San Antonio Creek Valley watershed, Santa Barbara County, California (California Department of Water Resources, 1959, 1968, 1977, 2000; LANDFIRE, 2014; California Department of Conservation, 2018): $A, 1959 ; B, 1968$; $C, 1977 ; D, 1986 ; E, 1996 ; F, 2006$, and $G, 2016$. 


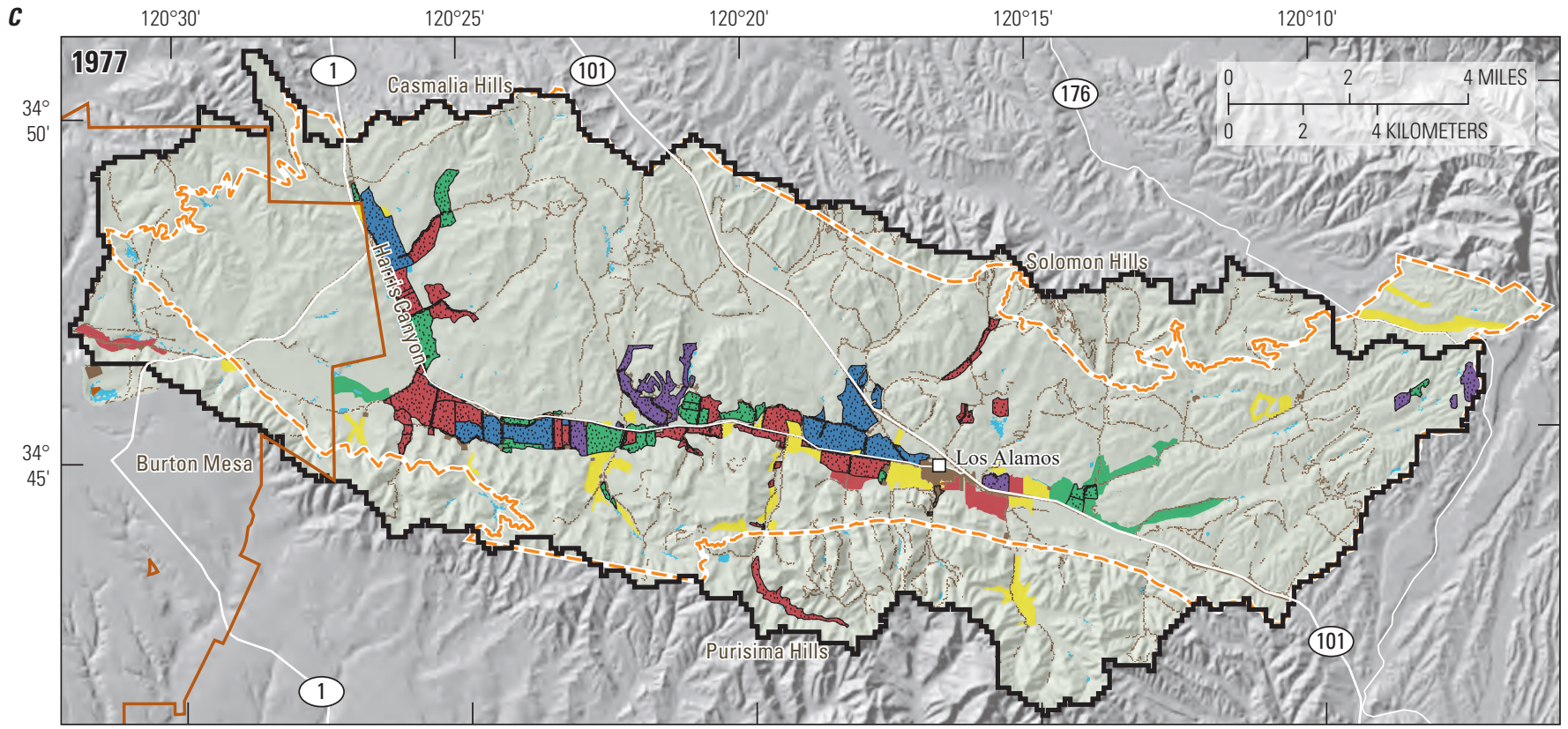

Base from U.S. Geological Survey and other Federal and State digital data, various scales; Universal Transverse Mercator projection, zone 10; North American Datum of 1983

D

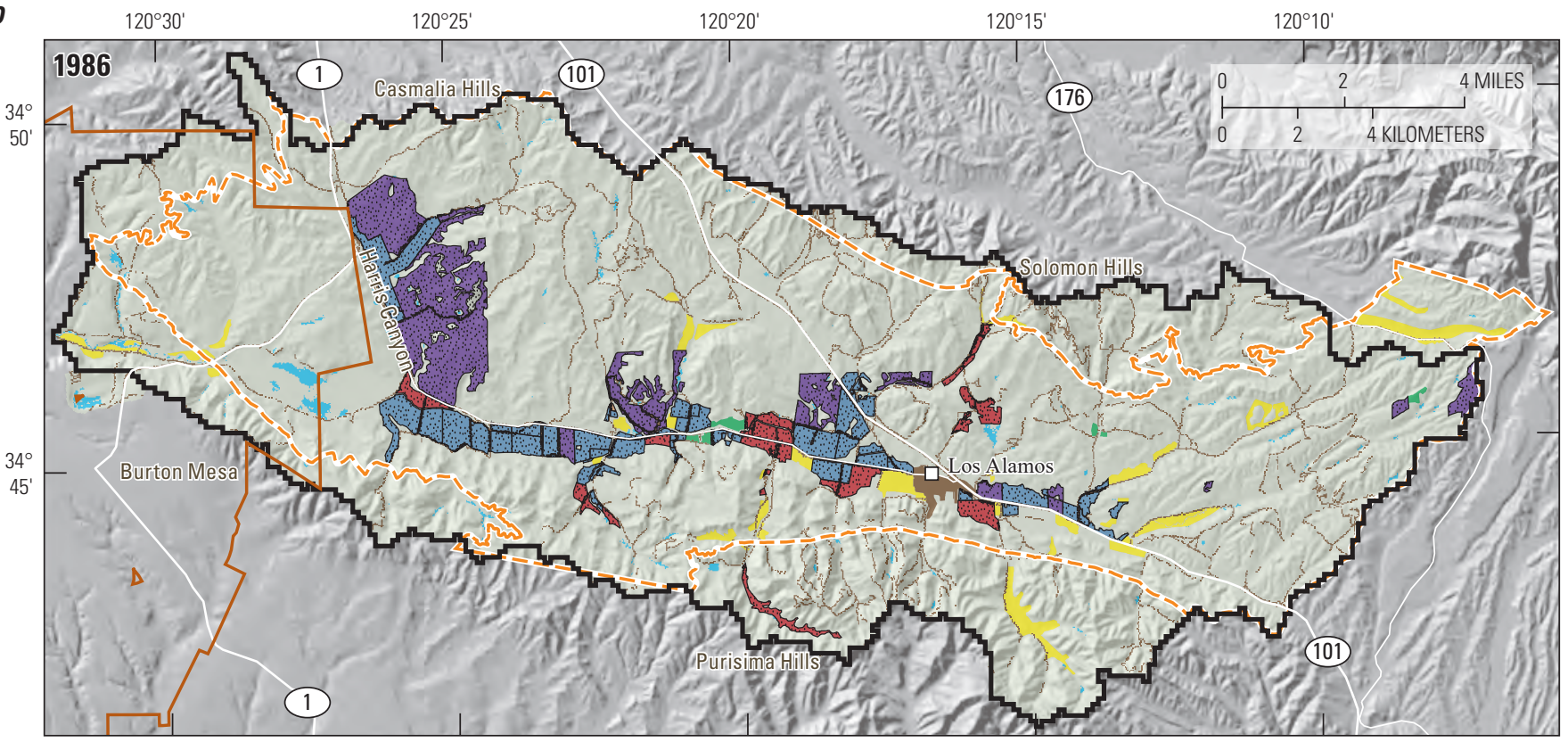

Base from U.S. Geological Survey and other Federal and State digital data, various scales;

Universal Transverse Mercator projection, zone 10; North American Datum of 1983

\section{EXPLANATION}

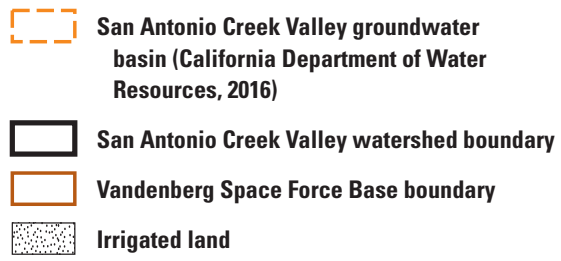

Figure 6.-Continued

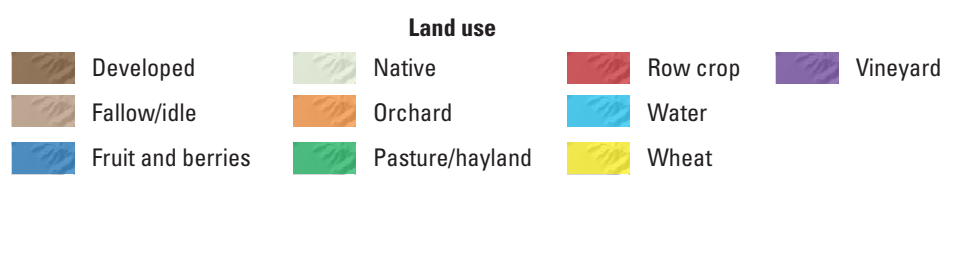




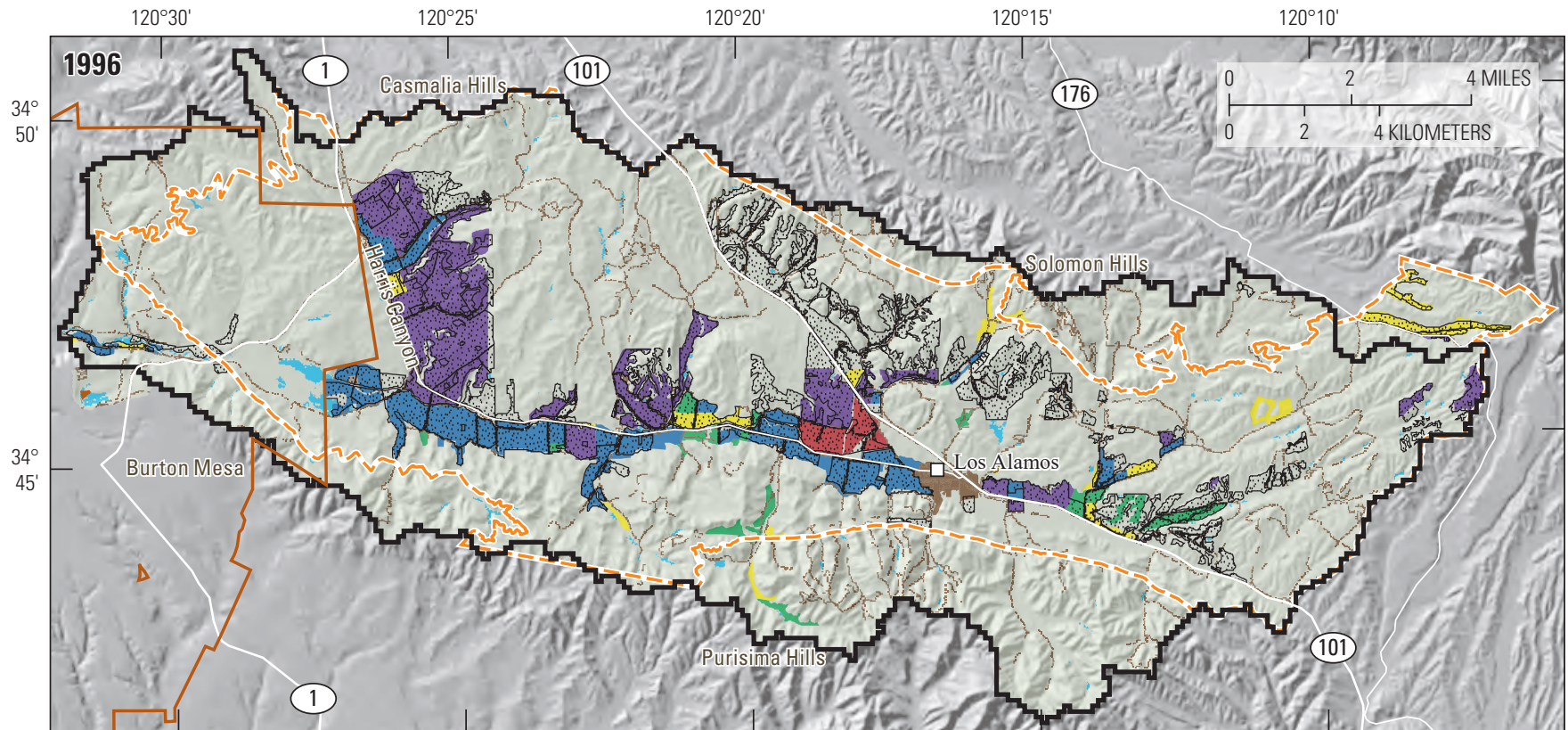

Base from U.S. Geological Survey and other Federal and State digital data, various scales:

Universal Transverse Mercator projection, zone 10; North American Datum of 1983

$\boldsymbol{F}$

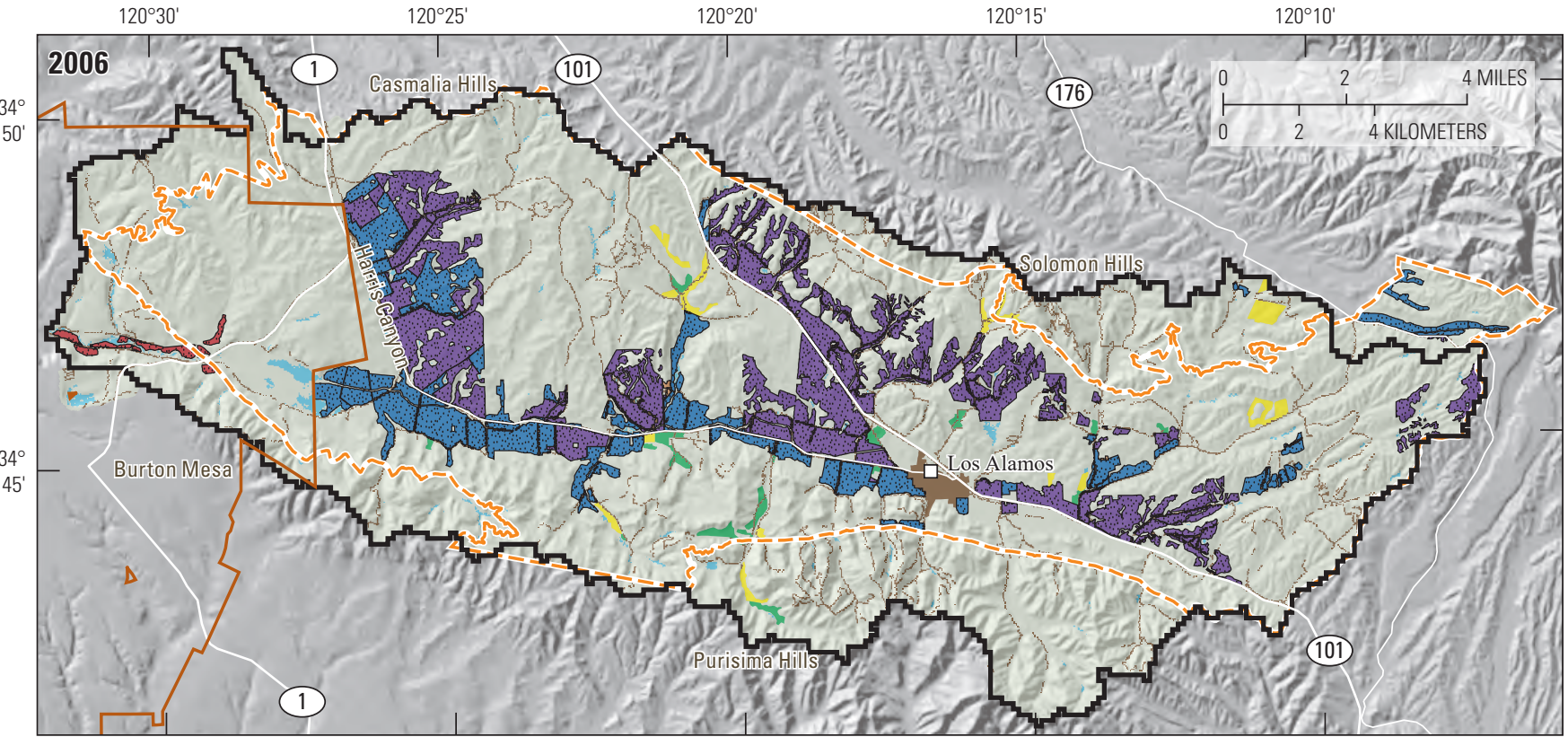

Base from U.S. Geological Survey and other Federal and State digital data, various scales;

Universal Transverse Mercator projection, zone 10; North American Datum of 1983

\section{EXPLANATION}

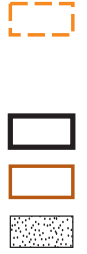

San Antonio Creek Valley groundwater basin (California Department of Water Resources, 2016)

San Antonio Creek Valley watershed boundary

Vandenberg Space Force Base boundary

Irrigated land

Figure 6.-Continued

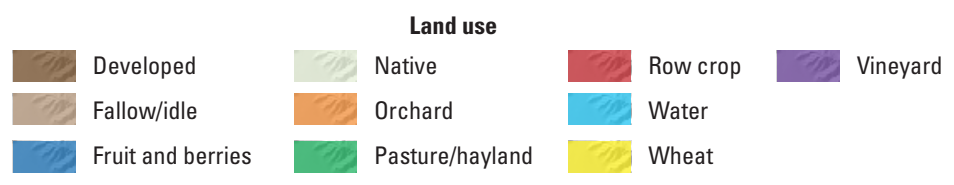


G

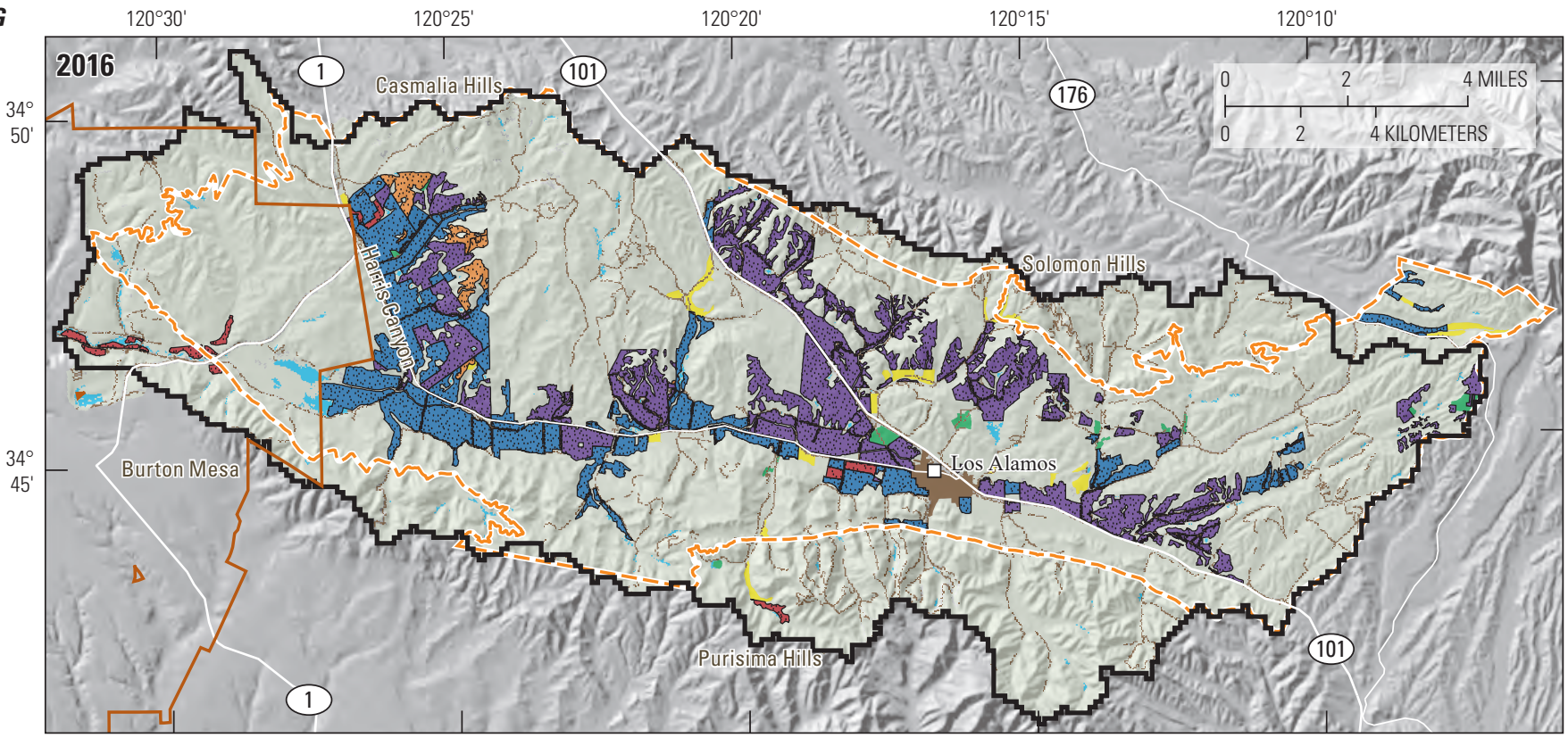

Base from U.S. Geological Survey and other Federal and State digital data, various scales: Universal Transverse Mercator projection, zone 10; North American Datum of 1983 basin Antonio Creek Valley groundwater
basifornia Department of Water Resources, 2016)

San Antonio Creek Valley watershed boundary

Vandenberg Space Force Base boundary Irrigated land

Figure 6.-Continued

\section{EXPLANATION}

Developed

Fallow/idle

Fruit and berries

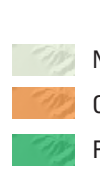

Land use

Native

Row crop

Water

Pasture/hayland Wheat 
A

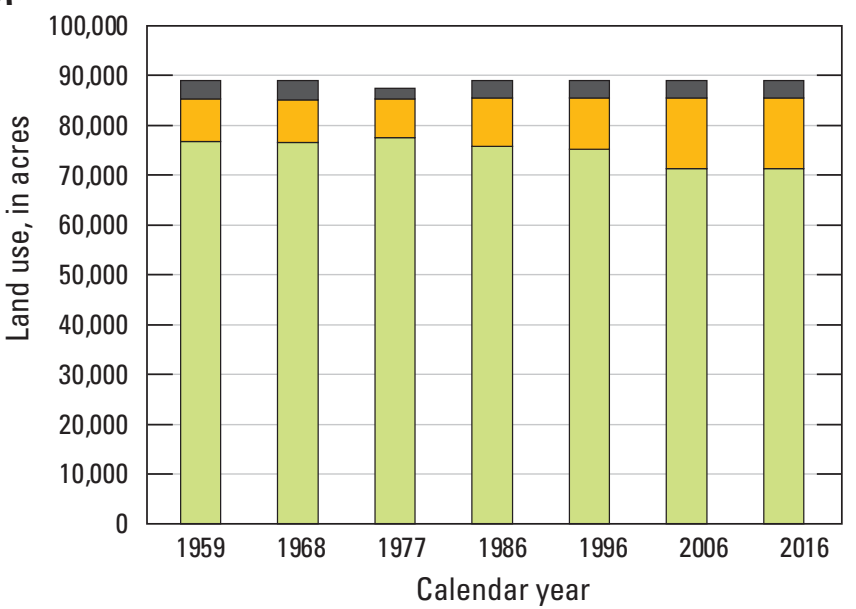

EXPLANATION

Native Vegetation

Agriculture

Developed

B

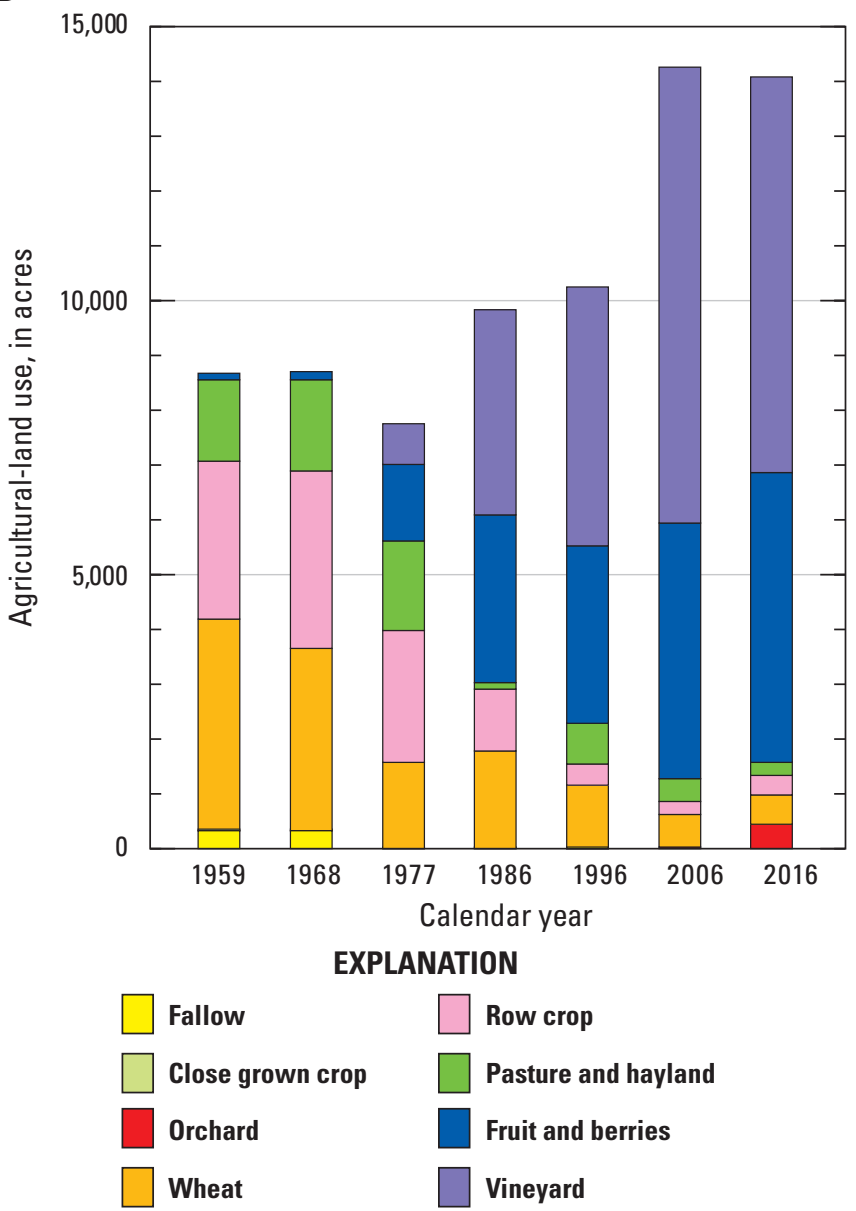

Figure 7. Changes in $A$, land use; and $B$, agricultural-land use for 1959, 1968, 1977, 1986, 1996, 2006, and 2016 for the San Antonio Creek Valley watershed, Santa Barbara County, California (California Department of Water Resources, 1959, 1968, 1977, 2000; LANDFIRE, 2014; California Department of Conservation, 2018). 


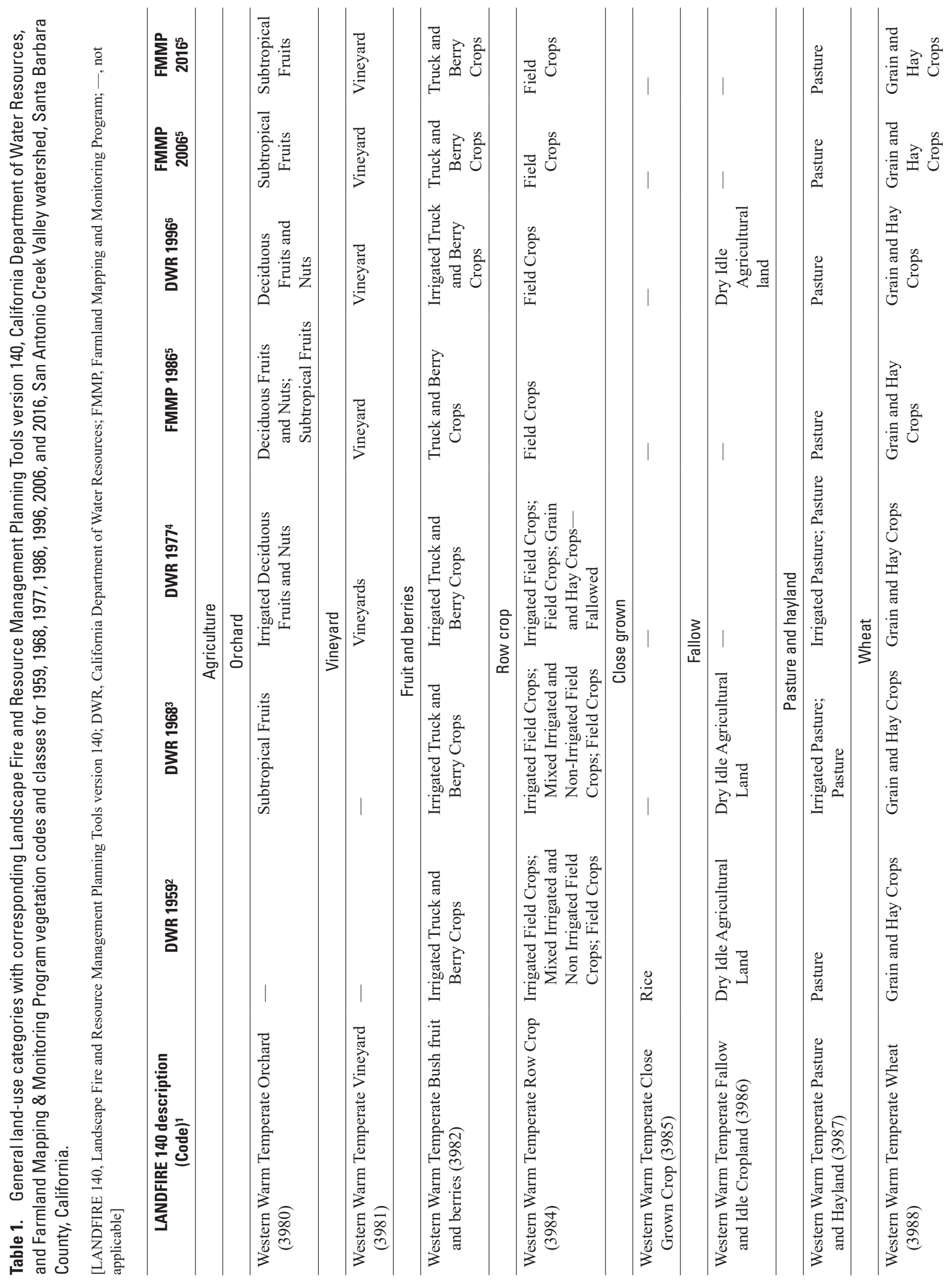




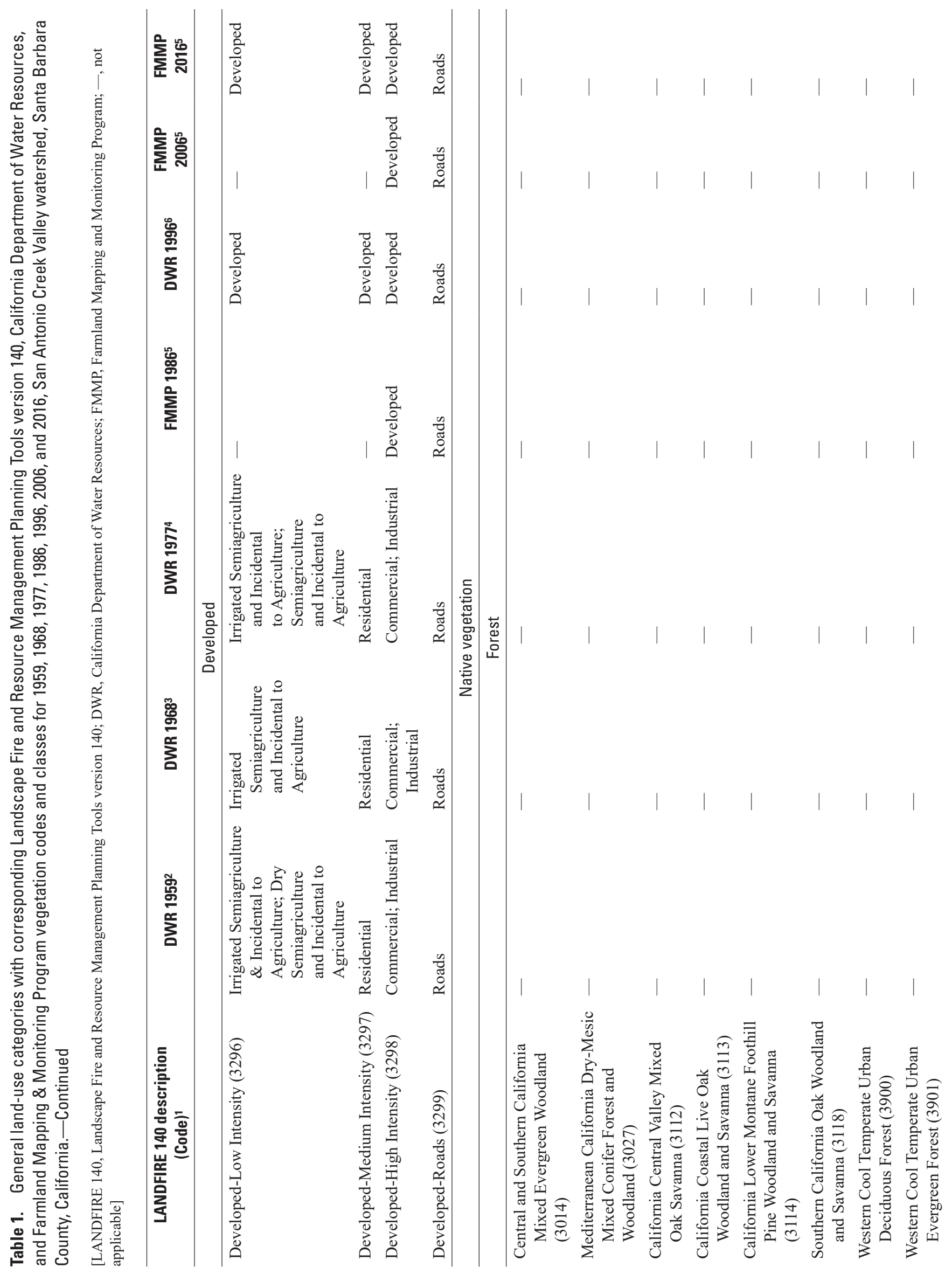



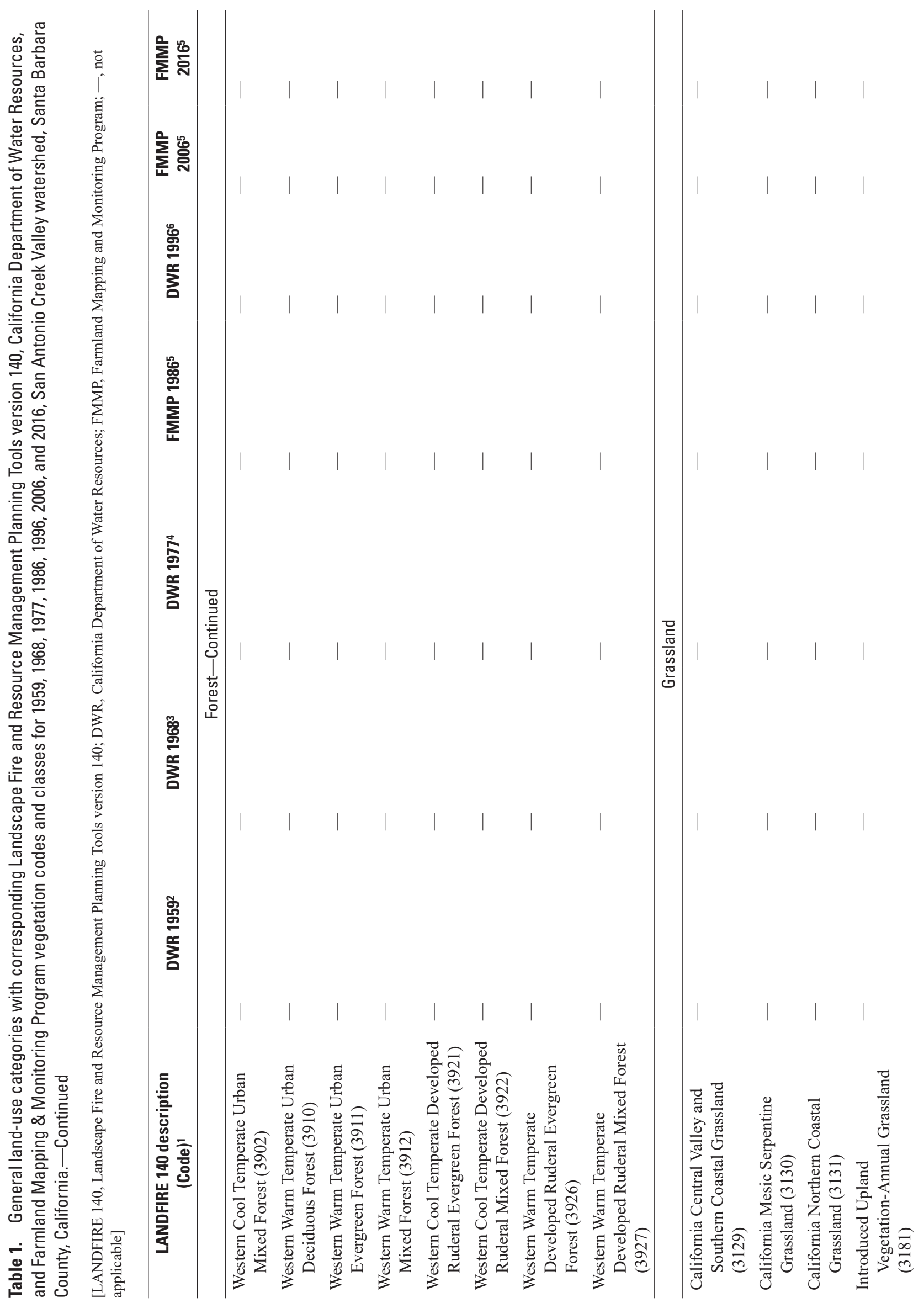


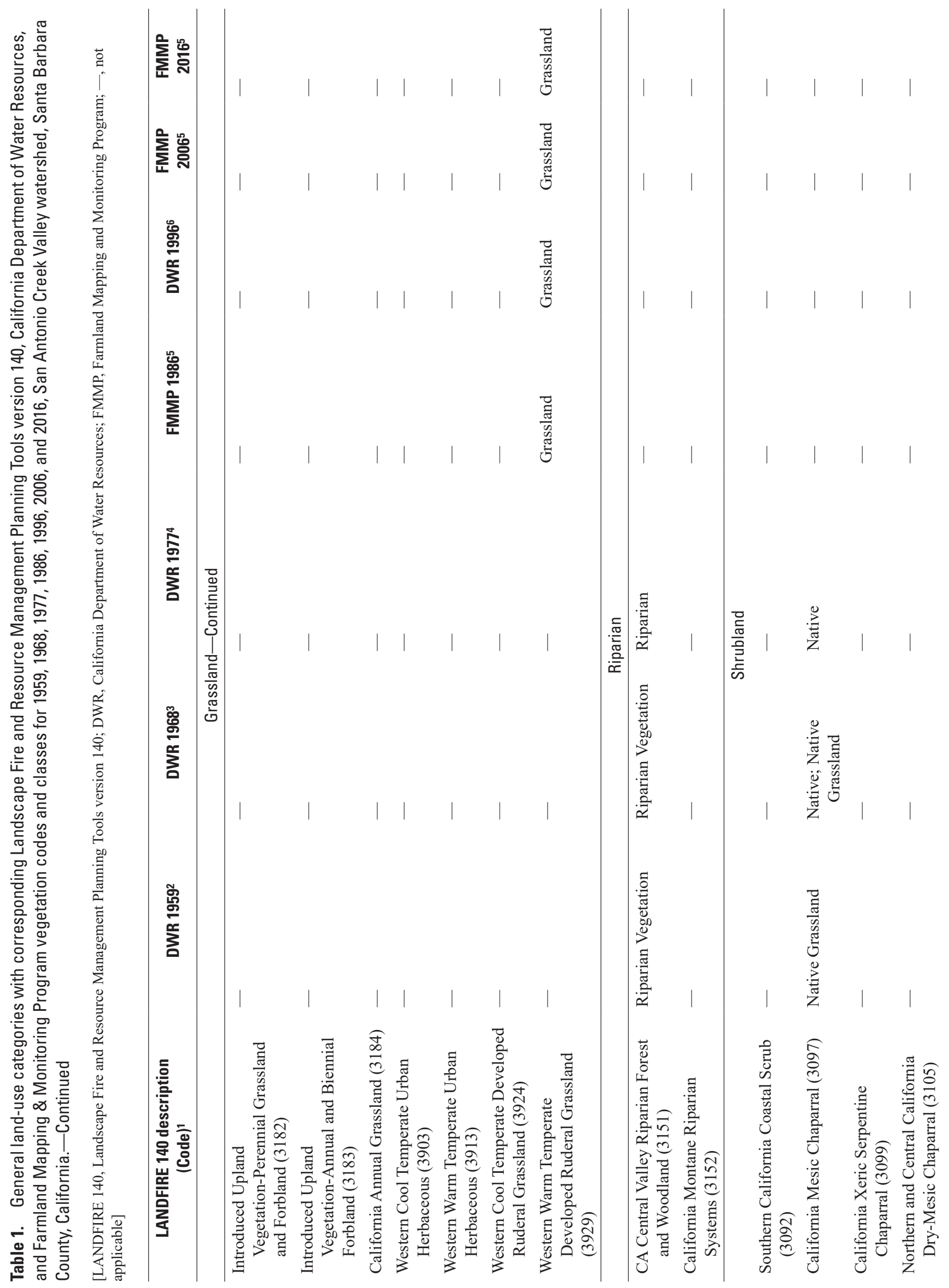



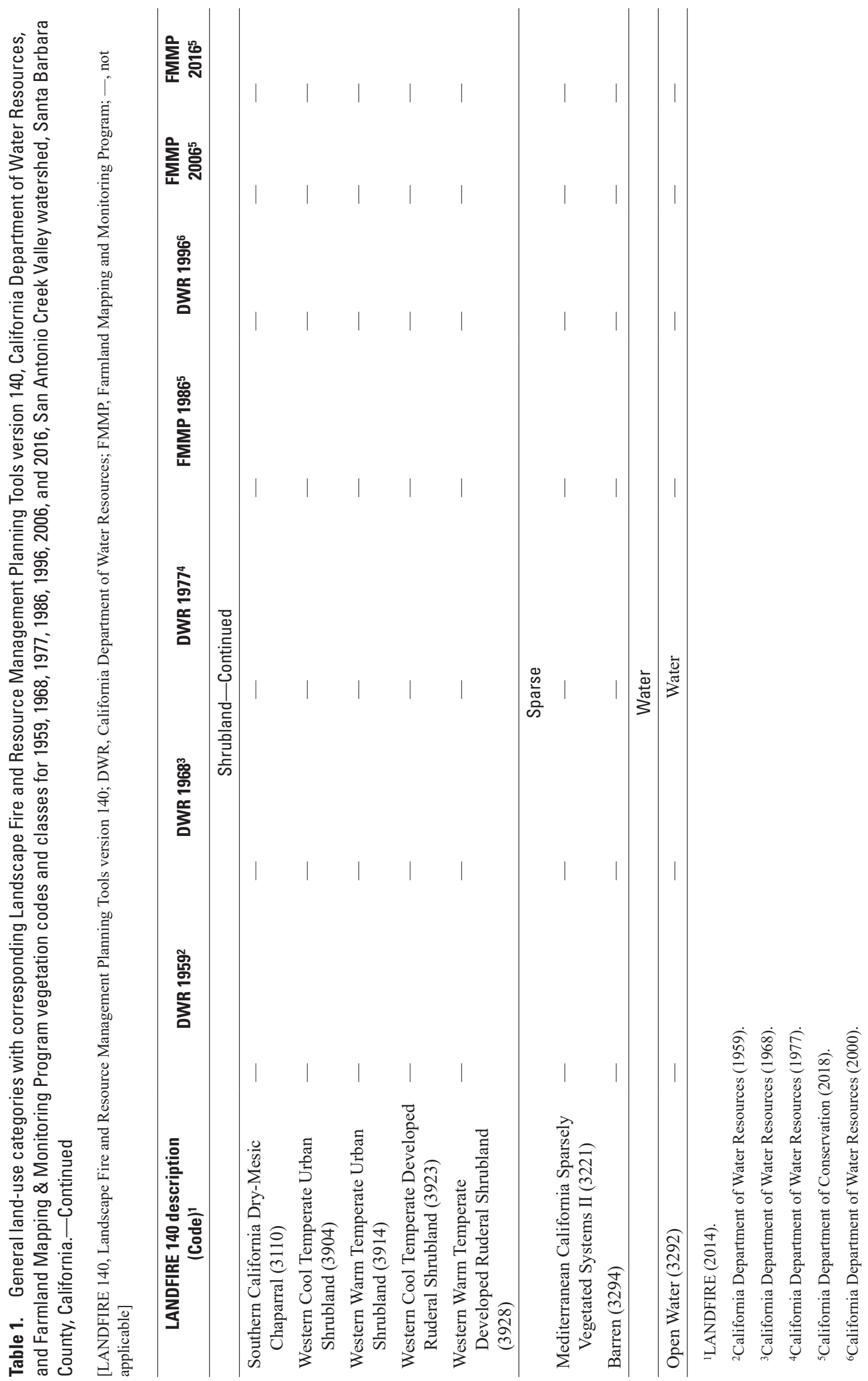
The SACVW was comprised of native vegetation (80.0 to 87.2 percent), agricultural land ( 8.7 to 16.0 percent), and developed land (3.9 to 4.3 percent; table 2) during 1959-2016. Land use in the SACVW was characterized by an increase in agricultural lands from 8,674 acres in 1959 (9.7 percent of total land use) to 14,080 acres in 2016 (15.8 percent of total land use) and an associated reduction in the amount of native vegetation from 76,700 acres ( 86.1 percent) in 1959 to 71,367 acres (80.1 percent) in 2016. The amount of developed land was relatively constant during 1959-2016, covering between 3,459 to 3,853 acres (3.9 to 4.3 percent; figs. 6, 7; table 2).

Agricultural lands in the 1959, 1968, and 1977 were primarily on the valley floor along San Antonio Creek and in Harris Canyon in the northwest part of the study area, with small tracts of agricultural land in the narrow valleys and tributary streams south of San Antonio Creek (figs. 6A-C). In 1986 (fig. 6D), the acreage of agricultural lands increased in the narrow valleys and broad hillsides north of San Antonio
Creek; these additional agricultural lands extended from Harris Canyon to the northeastern boundary of the SACVW. During 1959-2016, agriculture acreage in the SACVW increased every year with available land-use data, except in 1977 and 2016, when the amount of agricultural land decreased by 947 and 181 acres, respectively, from the previous year with available land-use data (fig. 7; table 2). The largest increases in agricultural acreage occurred between 1977 and 1986, when the amount of agricultural land increased by 2,081 acres, and between 1996 and 2006, when the amount of agricultural land increased by 3,988 acres (table 2).

Increases in the amount of agricultural acreage were accompanied by a shift in crop types and an associated shift in farming practices from predominantly non-irrigated dry farming in 1959, to almost entirely irrigated farming in 2016 (table 2). Crop types changed from predominantly wheat, row crops, and pasture and hayland, to predominantly vineyards and fruit and berries (figs. 6, 7; table 2). 
Table 2. General land-use categories and agricultural sub-categories for 1959, 1968, 1977, 1986, 1996, 2006, and 2016 San Antonio Creek Valley watershed, Santa Barbara County, California (California Department of Water Resources, 1959, 1968, 1977, 2000; LANDFIRE, 2014; California Department of Conservation, 2018).

[Percent calculations are for the total area; Total Area is the sum of developed, agricultural, and native vegetation land from geographic information systems (GIS) polygons, resulting in slight differences between years. Abbreviations: $\mathrm{mi}^{2}$, square mile; —, not applicable]

\begin{tabular}{|c|c|c|c|c|c|c|c|c|c|}
\hline \multirow{2}{*}{ General land-use type } & \multicolumn{3}{|c|}{1959} & \multicolumn{3}{|c|}{1968} & \multicolumn{3}{|c|}{1977} \\
\hline & Acres & $\mathrm{mi}^{2}$ & Percent & Acres & $\mathbf{m i}^{2}$ & Percent & Acres & $\mathrm{mi}^{2}$ & Percent \\
\hline Developed & 3,666 & 5.7 & 4.1 & 3,853 & 6.0 & 4.3 & 3,667 & 5.7 & 4.1 \\
\hline Agriculture & 8,674 & 13.6 & 9.7 & 8,704 & 13.6 & 9.8 & 7,757 & 12.1 & 8.7 \\
\hline Irrigated & 2,118 & 3.3 & 2.4 & 2,059 & 3.2 & 2.3 & 5,094 & 8.0 & 5.8 \\
\hline Mixed Irrigated/non-irrigated & 14 & 0.0 & 0.0 & 1,235 & 1.9 & 1.4 & 0 & 0.0 & 0.0 \\
\hline Non-irrigated & 6,541 & 10.2 & 7.3 & 5,410 & 8.5 & 6.1 & 2,662 & 4.2 & 3.0 \\
\hline Orchard & - & - & - & 3.2 & 0.0 & 0.0 & 5 & 0.0 & 0.0 \\
\hline Vineyard & - & - & - & - & - & - & 732 & 1.1 & 0.8 \\
\hline Fruit and berries & 116 & 0.2 & 0.1 & 125.4 & 0.2 & 0.1 & 1,403 & 2.2 & 1.6 \\
\hline Row crop & 2,877 & 4.5 & 3.2 & $3,232.4$ & 5.1 & 3.6 & 2,390 & 3.7 & 2.7 \\
\hline Close grown & 4 & 0.01 & 0.0 & - & - & - & - & - & - \\
\hline Fallow & 345 & 0.5 & 0.4 & 338.8 & 0.5 & 0.4 & - & - & - \\
\hline Pasture and hayland & 1,477 & 2.3 & 1.7 & $1,670.1$ & 2.6 & 1.9 & 1,639 & 2.6 & 1.9 \\
\hline Wheat & 3,855 & 6.0 & 4.3 & $3,334.5$ & 5.2 & 3.7 & 1,589 & 2.5 & 1.8 \\
\hline Native vegetation & 76,700 & 119.8 & 86.1 & 7,6481 & 119.5 & 85.9 & 77,617 & 121.3 & 87.2 \\
\hline Total area & 89,039 & 139 & - & 89,039 & 139 & - & 89,041 & 139 & - \\
\hline
\end{tabular}

\section{Hydrogeology}

This section describes the hydrogeologic characteristics of the SACVW, including surface-water hydrology, the geologic setting and aquifer system, sources of recharge to and discharge from the groundwater system, and long-term trends in groundwater levels, flow, and movement within the SACVW. Descriptions of surface-water and groundwater conditions in the SACVW are based on streamflow and groundwater-level measurement data as well as estimated and reported water-use information. Descriptions of the geologic setting and aquifer system are based on previously published maps, hydraulic measurement data, and a three-dimensional (3D) hydrogeologic framework model (HFM) of the SACVW developed as part of this study.

\section{Surface Water}

Knowledge of the spatial and temporal characteristics of streamflow is needed for municipal, industrial, agricultural, and other water-supply and flood-control projects (Viessman and Lewis, 2003). Streamflow records from streamgages in the SACVW were analyzed to develop a better understanding of the seasonal and interannual distributions of streamflow. The analysis of streamflow was used to help characterize the hydrologic system of the SACVW. Data from the USGS National Hydrography Dataset (NHD; U.S. Geological Survey, 2016) were used to describe the surface-water hydrology of the SACVW in this section and are available from the USGS National Map website (https://www.usgs.gov/core-sciencesystems/national-geospatial-program/national-map).

The SACVW coincides with the drainage basin of USGS station 11136100 (San Antonio Creek near Casmalia, Calif., hereafter referred to as the "Casmalia streamgage"; fig. 8; table 3; U.S. Geological Survey, 2021). The surface-water drainage pattern within the SACVW generally is dendritic (Zernitz, 1932). The main stem of San Antonio Creek runs for about $34 \mathrm{mi}$ in a general westerly direction from its headwaters in the Solomon Hills to the Pacific Ocean about 6 mi west of the SACVW (figs. 1, 8). The first $28 \mathrm{mi}$ of the main stem is within the SACVW. All of San Antonio Creek east of Barka Slough is classified in the NHD as intermittent, but west of Barka Slough, San Antonio Creek is classified as perennial (fig. 8; U.S. Geological Survey, 2016). The perennial reach of San Antonio Creek begins at Barka Slough, where consolidated bedrock underlying the SACVW at shallow depth creates a barrier to groundwater flow that, combined with the narrowing of the valley, causes almost all groundwater to move upward to the land surface and discharge into San Antonio Creek (Muir, 1964). All tributaries to San Antonio Creek within the SACVW are classified as intermittent (fig. 8). 
Table 2. General land-use categories and agricultural sub-categories for 1959, 1968, 1977, 1986, 1996, 2006, and 2016 San Antonio Creek Valley watershed, Santa Barbara County, California (California Department of Water Resources, 1959, 1968, 1977, 2000; LANDFIRE, 2014; California Department of Conservation, 2018).-Continued

[Percent calculations are for the total area; Total Area is the sum of developed, agricultural, and native vegetation land from geographic information systems (GIS) polygons, resulting in slight differences between years. Abbreviations: $\mathrm{mi}^{2}$, square mile; - , not applicable]

\begin{tabular}{|c|c|c|c|c|c|c|c|c|c|c|c|}
\hline \multicolumn{3}{|c|}{1986} & \multicolumn{3}{|c|}{1996} & \multicolumn{3}{|c|}{2006} & \multicolumn{3}{|c|}{2016} \\
\hline Acres & $\mathrm{mi}^{2}$ & Percent & Acres & $m i^{2}$ & Percent & Acres & $\mathrm{mi}^{2}$ & Percent & Acres & $m i^{2}$ & Percent \\
\hline 3,459 & 5.4 & 3.9 & 3,569 & 5.6 & 4.0 & 3,522 & 5.5 & 4.0 & 3,597 & 5.6 & 4.0 \\
\hline 9,838 & 15.4 & 11.0 & 10,273 & 16.1 & 11.5 & 14,261 & 22.3 & 16.0 & 14,080 & 22.0 & 15.8 \\
\hline 7,923 & 12.4 & 8.9 & 8,892 & 13.9 & 10.0 & 13,246 & 20.7 & 14.9 & 13,310 & 20.8 & 14.9 \\
\hline 0 & 0.0 & 0.0 & 0 & 0.0 & 0.0 & 0 & 0.0 & 0.0 & 0 & 0.0 & 0.0 \\
\hline 1,914 & 3.0 & 2.2 & 1,381 & 2.2 & 1.6 & 1,016 & 1.6 & 1.1 & 769 & 1.2 & 0.9 \\
\hline 7 & 0.0 & 0.0 & 3 & 0.0 & 0.0 & 33 & 0.1 & 0.0 & 450 & 0.7 & 0.5 \\
\hline 3,744 & 5.9 & 4.2 & 4,743 & 7.4 & 5.3 & 8,312 & 13.0 & 9.3 & 7,195 & 11.2 & 8.1 \\
\hline 3,061 & 4.8 & 3.4 & 3,243 & 5.1 & 3.6 & 4,671 & 7.3 & 5.2 & 5,292 & 8.3 & 5.9 \\
\hline 1,111 & 1.7 & 1.2 & 394 & 0.6 & 0.4 & 229 & 0.4 & 0.3 & 373 & 0.6 & 0.4 \\
\hline- & - & - & - & - & - & - & - & - & - & - & - \\
\hline- & - & - & 15 & 0.0 & - & - & - & - & - & - & - \\
\hline 122 & 0.2 & 0.1 & 737 & 1.2 & 0.8 & 411 & 0.6 & 0.5 & 243 & 0.4 & 0.3 \\
\hline 1,792 & 2.8 & 2.0 & 1,139 & 1.8 & 1.3 & 605 & 0.9 & 0.7 & 526 & 0.8 & 0.6 \\
\hline 75,746 & 118.4 & 85.1 & 75,202 & 117.5 & 84.5 & 71,260 & 111.3 & 80.0 & 71,367 & 111.5 & 80.1 \\
\hline 89,043 & 139 & - & 89,044 & 139 & - & 89,043 & 139 & 100.0 & 89,043 & 139 & - \\
\hline
\end{tabular}

Many tributary stream courses beginning in the hills above the valley floor become ill-defined, and some stream courses disappear altogether as the streams approach the valley floor.

\section{Surface-Water Monitoring}

Streamflow has been measured at five USGS streamgages along San Antonio Creek and its tributaries (fig. 8; U.S. Geological Survey, 2021). These five streamgages have had varying periods of operation starting in 1941 (fig. 9; table 3; note, fig. 9 only shows streamflow data from 1948 to 2018). USGS station 11135800 (San Antonio Creek at Los Alamos, Calif., hereafter referred to as the "Los Alamos streamgage") was active during water years 1971-2018 with intermittent periods of inactivity during 1993-2002 (fig. 9). USGS stations 11136000 (San Antonio Creek at Harris, Calif., hereafter referred to as the "Harris Grade streamgage") and 11136050 (San Antonio Creek above Barka Slough, Calif., hereafter referred to as the "Barka streamgage") are about 9 mi downstream from the Los Alamos streamgage. The Harris Grade streamgage was operated for about 14 years during 1941-55, and the Barka streamgage was operated for about 3 years during 1985-87. USGS station 11136040 (Harris Canyon Creek near Orcutt, Calif., hereafter referred to as the "Harris Canyon streamgage") was installed as part of this study about $0.7 \mathrm{mi}$ upstream from the confluence of Harris Canyon and San Antonio Creek; the Harris Canyon streamgage (11136040) was operated for about 2 years during 2017-19. The Casmalia streamgage was about $2.8 \mathrm{mi}$ downstream from Barka Slough at the western boundary of the SACVW. The Casmalia streamgage (11136100) was operated during water years 1955-2003 (with one year of inactivity in 1994) and was reinstalled and operated as part of this study during 2014-18.

The Casmalia and Los Alamos streamgages have the longest periods of recorded streamflow in the SACVW (fig. 9). The water years with the highest mean annual streamflow at the Casmalia streamgage - 1978, 1983, and 1998 - had some of the highest annual precipitation on record (fig. 9). Mean annual streamflow at the Casmalia streamgage during 1956-2018 was about 6.1 cubic feet per second (ft3/s), or about 4,400 acre-feet per year (acre-ft/yr). At the Casmalia streamgage, the highest mean monthly streamflows are during the rainy season (November through April) and the lowest mean monthly streamflows are during the dry season (May through October; figs. 4, 10; table 3). During the dry season, streamflow at the Los Alamos streamgage usually was zero. At the Casmalia streamgage, streamflow during the dry season was low. Streamflow at the Los Alamos streamgage consisted almost entirely of direct runoff, which was an indication that the stream was not connected to the groundwater system at, and upstream of, the Los Alamos streamgage. The Harris Canyon streamgage, on a tributary to San Antonio Creek, had sporadic dry-season streamflow, indicated by non-zero mean monthly streamflow values (table 3); the low flows at this streamgage may derive from irrigation runoff or shallow subsurface flow from nearby agricultural fields. 


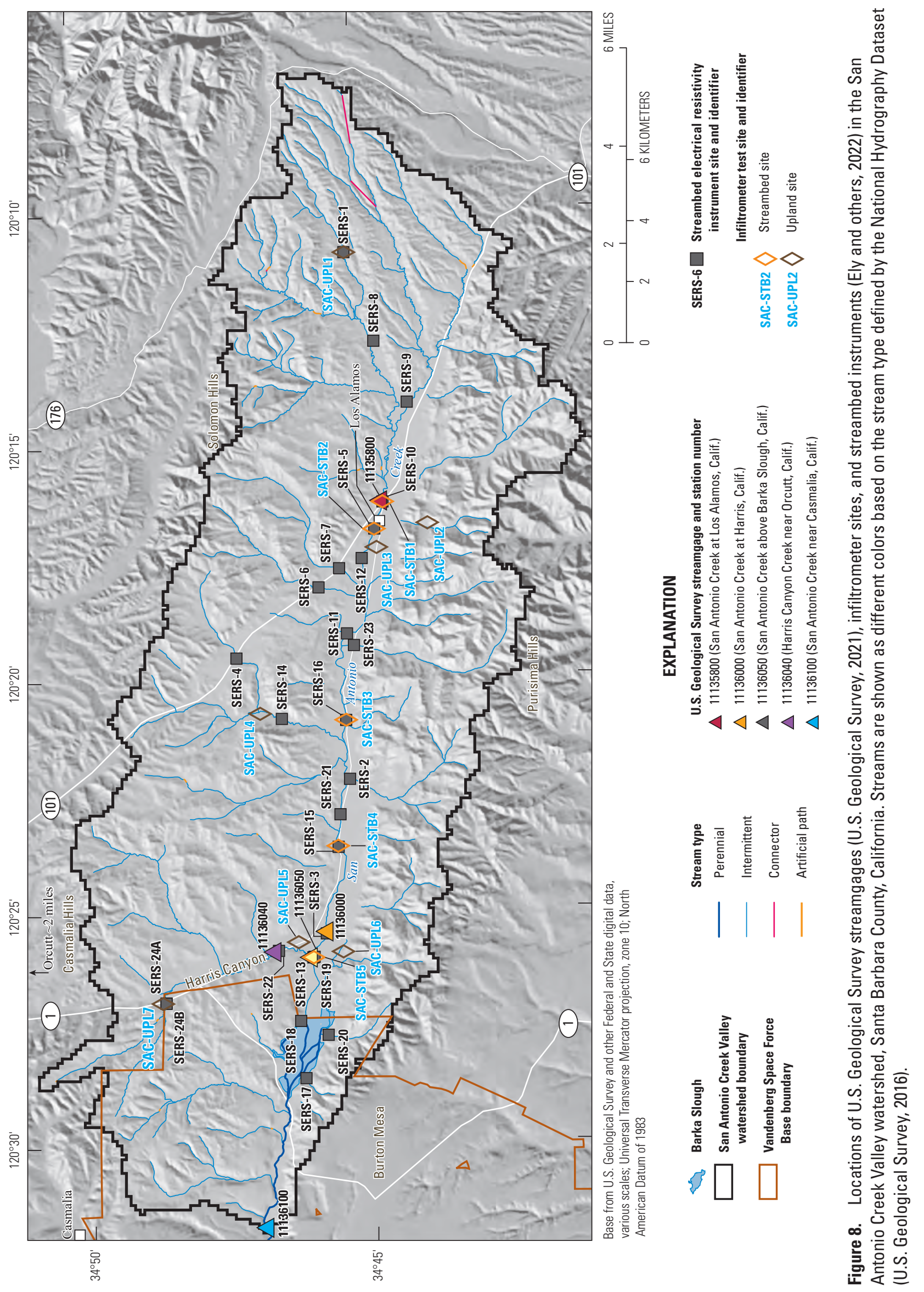


A

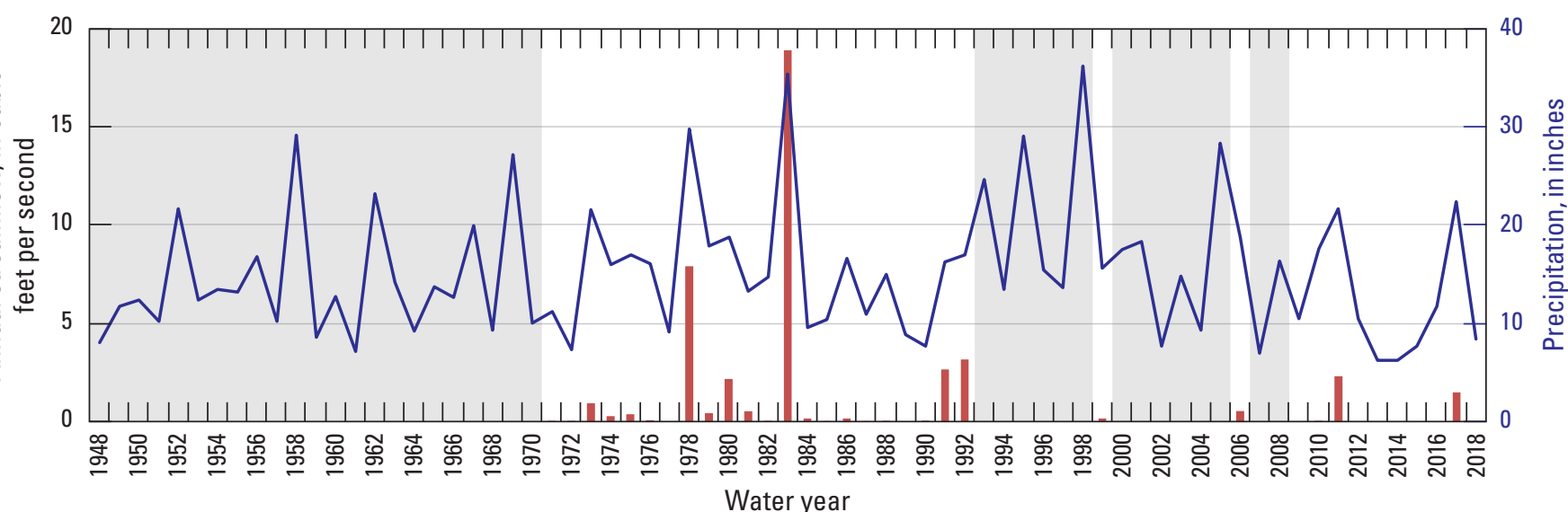

EXPLANATION

11135800 (San Antonio Creek at Los Alamos, Calif.) No streamflow data

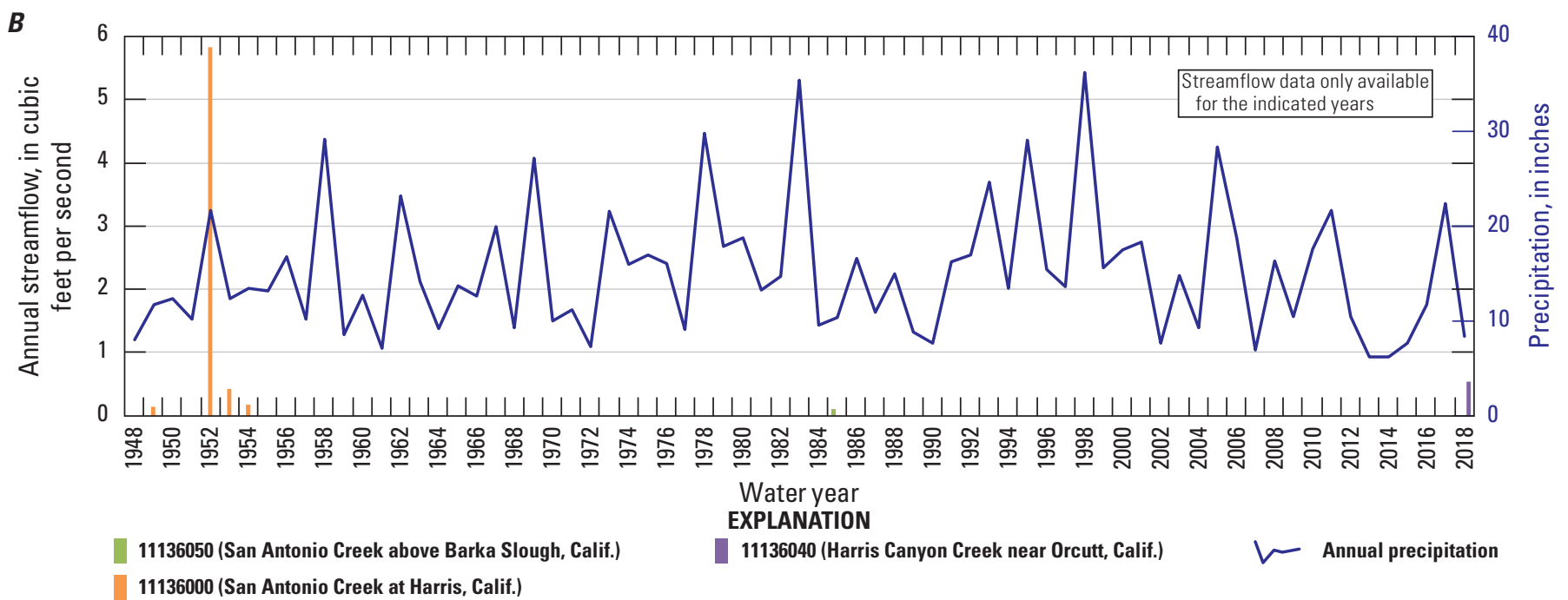

C

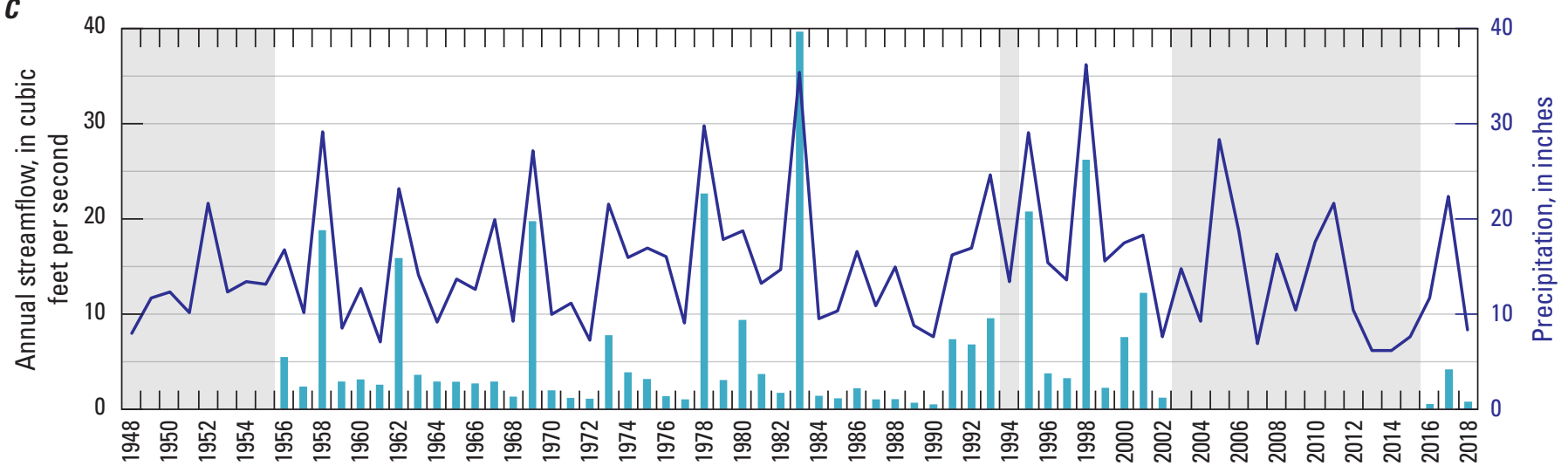

Water year

EXPLANATION

11136100 (San Antonio Creek near Casmalia, Calif.)

No streamflow data

- Annual precipitation

Figure 9. Mean annual streamflow at U.S. Geological Survey streamgages in the San Antonio Creek Valley watershed, Santa Barbara County, California (U.S. Geological Survey, 2021). A, U.S. Geological Survey station 11135800; B, U.S. Geological Survey stations 11136050, 11136000, and 11136040; C, U.S. Geological Survey station 11136100. Annual precipitation shown for the town of Los Alamos (climate station 204, Los Alamos Fire Station \#24; Santa Barbara County, 2019). Streamflow data are shown only for water years with complete records. 
Table 3. Description and summary monthly statistics of USGS stream gages active during water years 1948-2018 in the San Antonio Creek Valley watershed, Santa Barbara County, California. (U.S. Geological Survey, 2021).

[USGS, U.S. Geological Survey; mi², square mile; Jan., January; Feb. February; Mar., March; Apr., April; Aug., August; Sept., September; Oct., October; Nov., November; Dec., December —, unavailable]

\begin{tabular}{|c|c|c|c|}
\hline $\begin{array}{c}\text { USGS } \\
\text { station } \\
\text { number }\end{array}$ & USGS station name & $\begin{array}{c}\text { Area of } \\
\text { drainage } \\
\text { basin, in } \\
\mathrm{mi}^{2}\end{array}$ & Period of record \\
\hline 11135800 & San Antonio Creek at Los Alamos, California & 34.9 & $\begin{array}{l}\text { Oct. } 1970-\text { Sept. 1992, Oct. 1997-Sept. 1999, Oct. 2003- } \\
\text { current (Dec. 2021) }\end{array}$ \\
\hline 11136000 & San Antonio Creek at Harris, California (Harris Grade) & 93.7 & Jan. 1941-Sept. 1955 \\
\hline 11136040 & Harris Canyon Creek near Orcutt, California & 17.3 & Dec. 14, 2016-Jan. 20, 2019 \\
\hline 11136100 & San Antonio Creek near Casmalia, California & 135 & $\begin{array}{l}\text { Oct. 1955-Sept. 1993, Oct. 1994-Sept. 2003, Oct. 2014- } \\
\text { current (Dec. 2021) }\end{array}$ \\
\hline
\end{tabular}

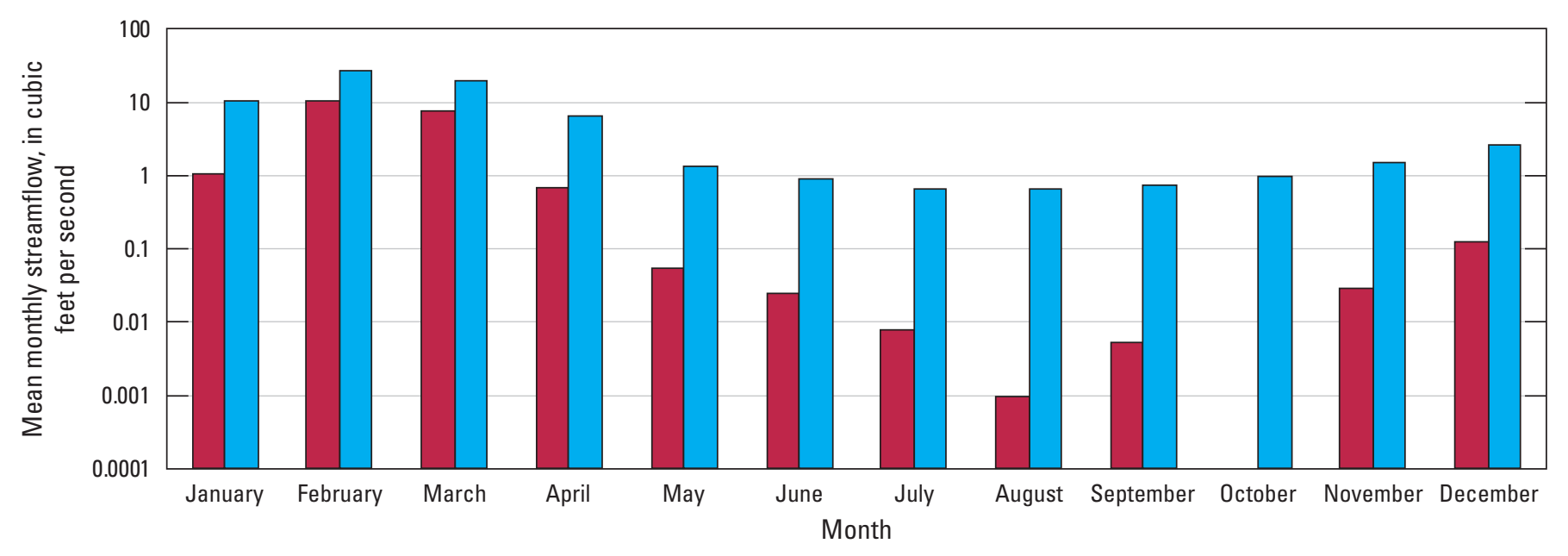

EXPLANATION

U.S. Geological Survey streamgage and station number

11135800 (San Antonio Creek at Los Alamos, Calif.)

11136100 (San Antonio Creek near Casmalia, Calif.)

Figure 10. Mean monthly streamflow during water years 1948-2018 at U.S. Geological Survey stations 11135800 and 111361000 on San Antonio Creek (U.S. Geological Survey, 2021), San Antonio Creek Valley watershed, Santa Barbara County, California. 
Table 3. Description and summary monthly statistics of USGS stream gages active during water years 1948-2018 in the San Antonio Creek Valley watershed, Santa Barbara County, California. (U.S. Geological Survey, 2021).-Continued

[USGS, U.S. Geological Survey; mi² , square mile; Jan., January; Feb. February; Mar., March; Apr., April; Aug., August; Sept., September; Oct., October; Nov., November; Dec., December —, unavailable]

\begin{tabular}{|c|c|c|c|c|c|c|c|c|c|c|c|c|}
\hline \multirow{2}{*}{$\begin{array}{c}\text { Status of } \\
\text { streamgage as of } \\
\text { December 1, } \\
2021\end{array}$} & \multicolumn{12}{|c|}{$\begin{array}{l}\text { Mean monthly streamflow }{ }^{1} \\
\text { (cubic feet per second) }\end{array}$} \\
\hline & Jan. & Feb. & Mar. & Apr. & May & June & July & Aug. & Sept. & Oct. & Nov. & Dec. \\
\hline Inactive & 2.7 & 0.03 & 7.9 & 0.05 & 0.00 & 0.00 & 0.00 & 0.00 & 0.00 & 0.00 & 0.07 & 0.53 \\
\hline Inactive & 4.9 & 8.2 & 2.3 & 0.26 & 0.06 & 0.92 & 0.24 & 0.07 & 0.01 & 0.02 & 0.39 & 0.12 \\
\hline Active & 10.0 & 27.0 & 20.0 & 6.50 & 1.30 & 0.89 & 0.65 & 0.66 & 0.74 & 1.00 & 1.60 & 2.60 \\
\hline
\end{tabular}

${ }^{1}$ Computed using available water years of data for the period 1948-2018.

\section{Base Flow to San Antonio Creek}

Base flow is defined as sustained or fair-weather streamflow composed of groundwater discharge and delayed subsurface runoff (Chow, 1964). The perennial streamflow of San Antonio Creek downstream of Barka Slough is demonstrated at the Casmalia streamgage (figs. 10, 11). Streamflow in this part of San Antonio Creek is a combination of direct runoff and base flow; however, during the dry season, streamflow at the Casmalia streamgage is sustained by base flow. Previous reported estimates of annual base flow over the various periods of record at the Casmalia streamgage ranged from about 430 acre-ft/yr (Martin, 1985) to about 2,330 acre-ft/yr (Hutchinson, 1980; table 4; fig. 12).

Estimates of base flow at the Casmalia streamgage were calculated using the Base-Flow Index (BFI) Standard method (Wahl and Wahl, 1995) in the USGS Groundwater Toolkit (Barlow and others, 2017). This computerized base-flow-separation method defines local streamflow minimums within consecutive, non-overlapping $n$-day periods and requires two parameters (1) $f$, the turning-point test factor, and (2) $n$, the number of days in a test window. In this study, the $f$ value used was 0.9 , the default value. The used $n$ value of 3 was determined using the method described by Wahl and Wahl (1995).

Estimated annual base flow at the Casmalia streamgage during water years 1956-2018 ranged from 0.24 to $5.84 \mathrm{ft}^{3} / \mathrm{s}$, and annual average base flow generally decreased during this period (fig. 12). Estimated annual base flow decreased from about $2.3 \mathrm{ft}^{3} / \mathrm{s}$ in the $1950 \mathrm{~s}$ and $1960 \mathrm{~s}$ to $0.75 \mathrm{ft}^{3} / \mathrm{s}$ in water year 1977, and then decreased to a low of $0.24 \mathrm{ft}^{3} / \mathrm{s}$ in water year 1990. Hutchinson (1980) and Martin (1985) estimated similar declines in base flows during 1956-77 (fig. 12) and generally considered this decline a response to increasing pumpage in the SACVW. During 1991-2003, estimated annual base flows ranged from $0.62 \mathrm{ft}^{3} / \mathrm{s}$ to $5.2 \mathrm{ft}^{3} / \mathrm{s}$. The climate during the period from 1956 to 2003 was characterized by wet and average precipitation years; estimated annual base flows increased during wet years and were generally the same for all average years during this period (fig. 12). During 2016-18, which followed a dry period from 2012 to 2015 , the average estimated annual base flow was $0.62 \mathrm{ft}^{3} / \mathrm{s}$. A more detailed analysis of base flows and the relation between groundwater recharge and discharge in the SACVW is presented in the "Estimates and Sources of Discharge" section. 
A

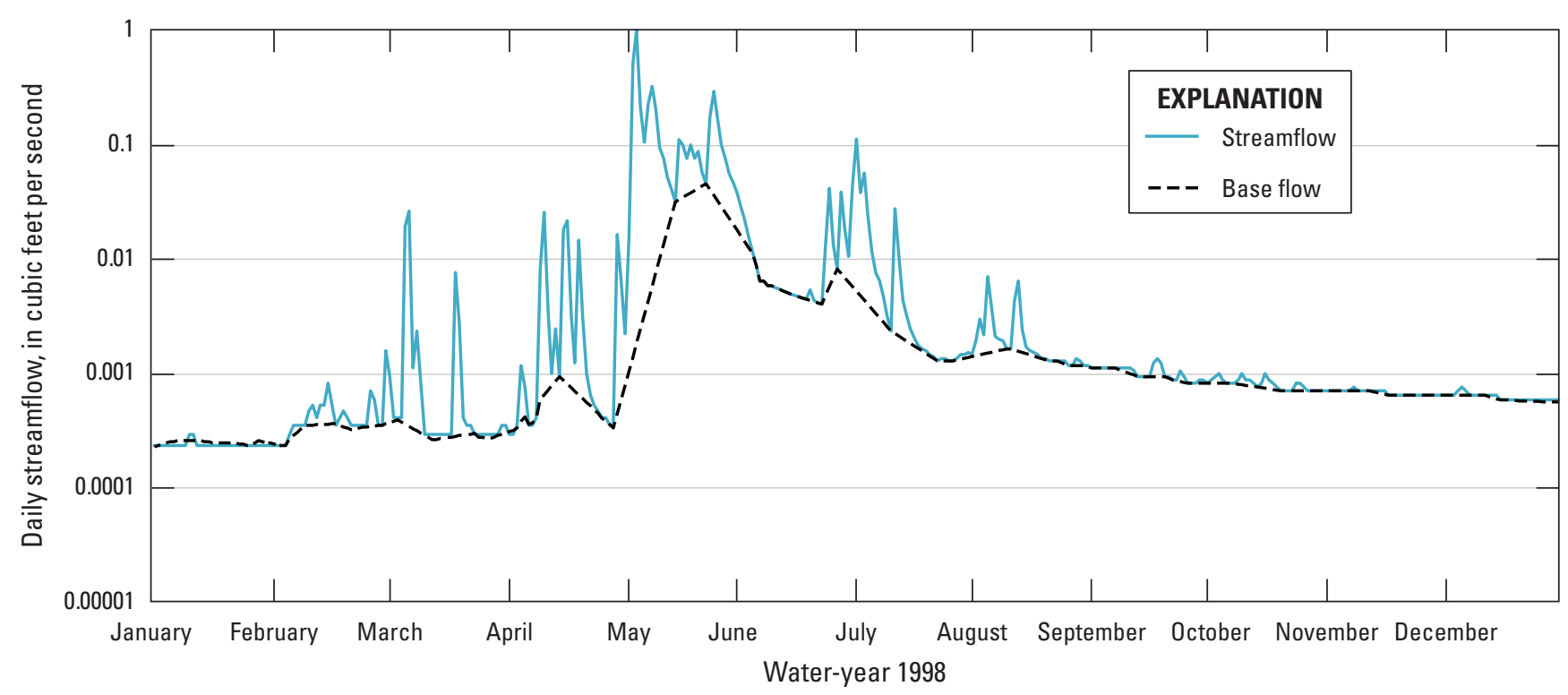

B

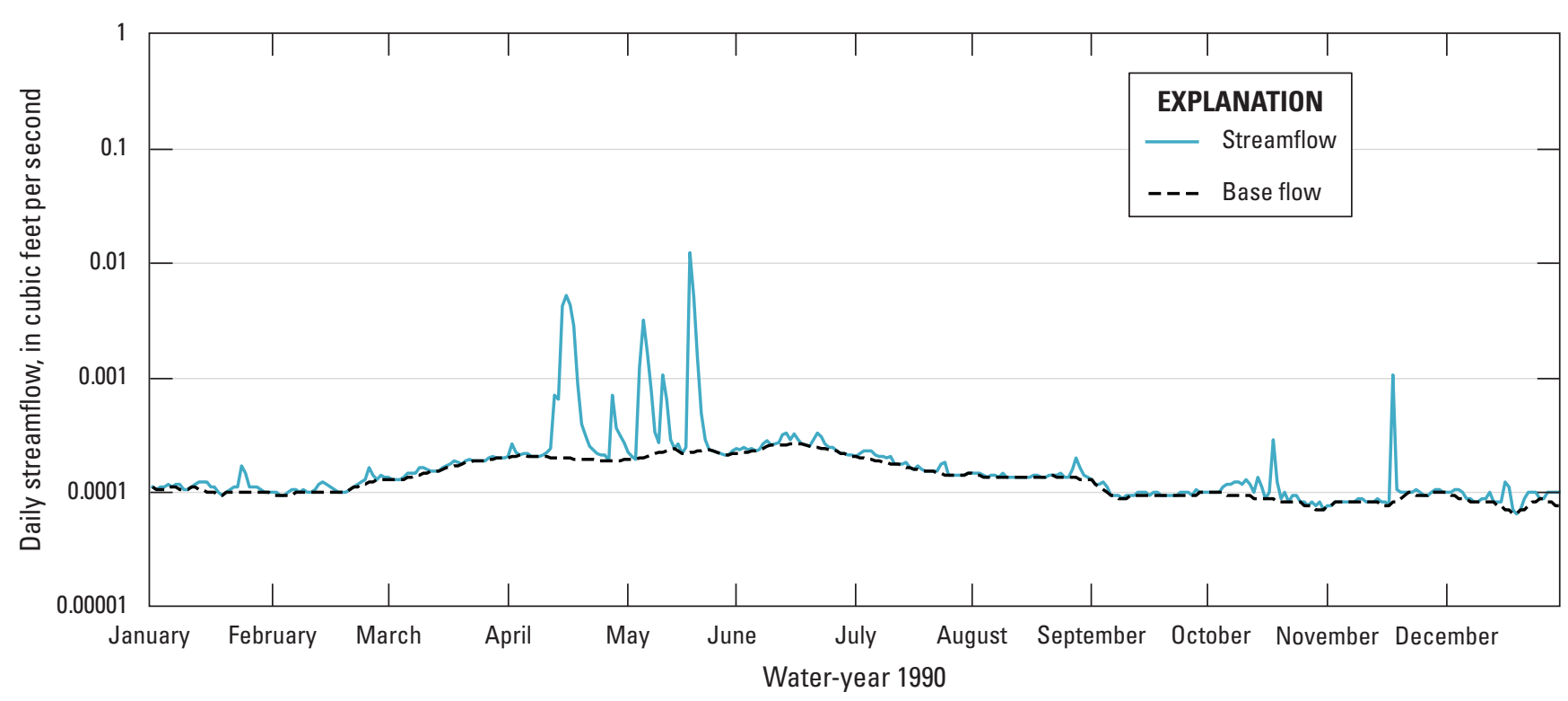

Figure 11. Measured daily streamflow and estimated daily base flow at U.S. Geological Survey station 11136100 U.S. Geological Survey, 2021) during $A$, a wet water year (1998); and $B$, a dry water year (1990), San Antonio Creek Valley watershed, Santa Barbara County, California. 
Table 4. Estimates of base flow at U.S. Geological Survey station 11136100 from this study and from previous studies using available measured streamflow data during water years 1956-2018 (U.S. Geological Survey, 2021), San Antonio Creek Valley watershed, Santa Barbara County, California.

$\left[\mathrm{ft}^{3} / \mathrm{s}\right.$, cubic foot per second; acre-ft/yr, acre-foot per year]

\begin{tabular}{|c|c|c|c|c|c|}
\hline \multirow{2}{*}{ Study } & \multirow{2}{*}{$\begin{array}{l}\text { Period of } \\
\text { record used }\end{array}$} & \multicolumn{2}{|c|}{ Mean annual base flow estimate } & \multicolumn{2}{|c|}{ Range of annual base flow estimates } \\
\hline & & $\left(\mathrm{ft}^{3} / \mathrm{s}\right)$ & (acre-ft/yr) & $\left(\mathrm{ft}^{3} / \mathrm{s}\right)$ & (acre-ft per yr) \\
\hline This study & 1956-2018 & 1.60 & 1,140 & $0.24-5.84$ & $172-4,230$ \\
\hline Martin (1985) & $1956-77$ & 0.96 & 695 & $0.59-1.56$ & $430-1,130$ \\
\hline Hutchinson (1980) & $1958-77$ & 1.75 & 1,270 & $0.79-3.22$ & $570-2,330$ \\
\hline
\end{tabular}

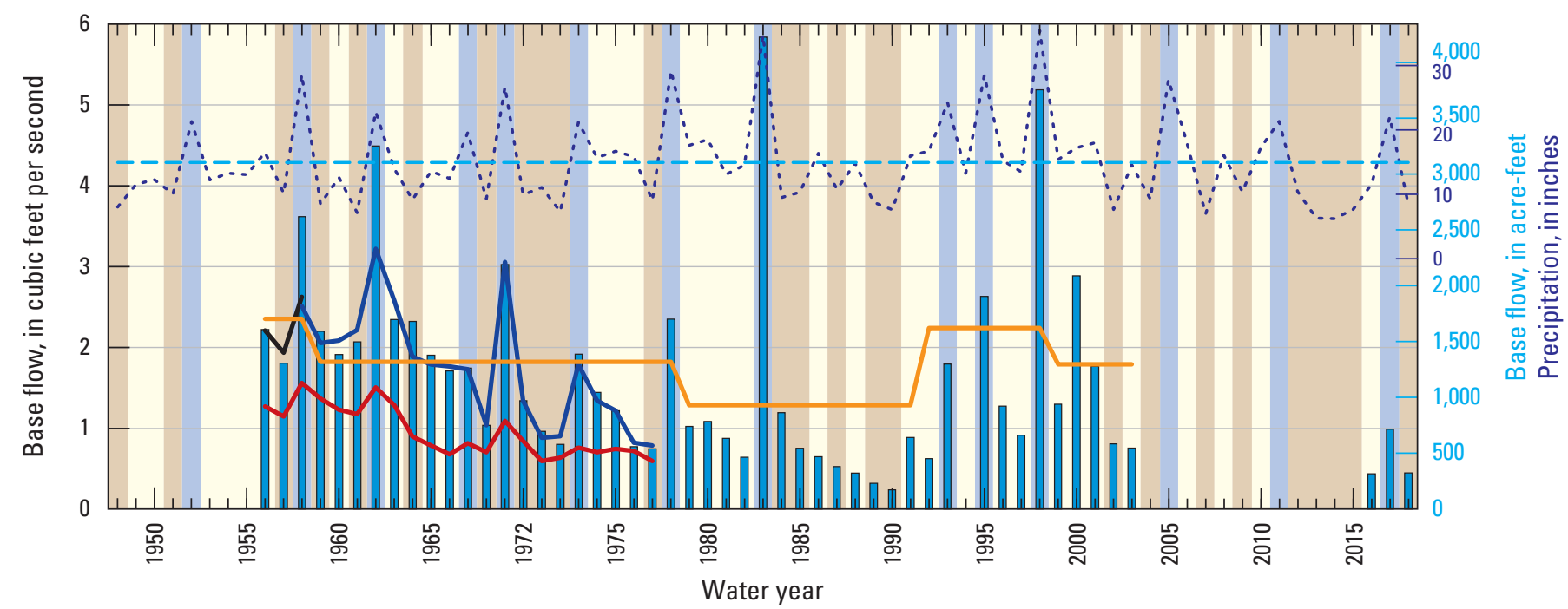

EXPLANATION

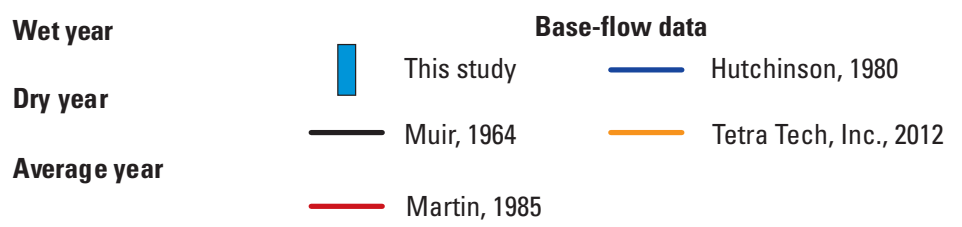

--- Average annual precipitation

Annual precipitation

Figure 12. Base flow at U.S. Geological Survey station 11136100 for water years 1956-2003 and 2016-18 (U.S. Geological Survey, 2021) and estimated average, wet, and dry annual precipitation, San Antonio Creek Valley watershed, Santa Barbara County, California. Average years had annual precipitation between 11.4 and 19.0 inches per year (in/yr), wet years had precipitation greater than $19.0 \mathrm{in} / \mathrm{yr}$, and dry years had precipitation less than $11.4 \mathrm{in} / \mathrm{yr}$ (Santa Barbara County, 2019). 


\section{Streambed Hydraulic Conductivity}

Infiltrometer tests were completed at 12 sites within the SACVW to quantify infiltration potential (fig. 8; table 5). Tests were performed during August 22-26, 2017, at five sites along the San Antonio Creek stream bed (SAC-STB1 through SAC-STB5) and seven sites along tributary streams (SAC-UPL1 through SAC-UPL7); the sites are numbered in ascending order from east to west to match the general direction of surface-water drainage and groundwater flow through the basin (fig. 8). Measurement data, analysis information, and results are published in a data release (Ely and others, 2022).

Infiltration tests were performed using large Mariotte bottles (Schwertz, 1950) and a double ring infiltrometer (Bouwer, 1986). Cumulative infiltration (I) was derived from Schwertz (1950) as:

$$
I=\left(\frac{r_{m}}{r_{r}}\right)^{2}\left(\frac{\Delta P_{g}}{\rho_{w} g}+\Delta h_{r}\right)
$$

where

$r_{m} \quad$ represents the inner radius of the Mariotte bottle ( 0.75 feet $)$,

$r_{r} \quad$ represents the radius of the inner ring of the double ring infiltrometer ( 0.98 feet),

$\Delta P_{g} \quad$ is the change in gas pressure in the head space of the Mariotte bottle (pounds per square inch),

$\rho_{w} \quad$ is the temperature dependent fluid density of water (62.3 pounds per cubic foot; Tanaka and others, 2001),

$g$ is gravity (32.2 feet per second squared), and $\Delta h_{r} \quad$ accounts for changes in water level in the inner ring, in feet.

Aquifer property data calculated from the infiltrometer test measurements were streambed hydraulic conductivity, infiltration rate, and specific yield and are shown as box and whisker plots in figure 13 and listed in table 5. Streambed hydraulic conductivity was calculated using common methods outlined by Philip (1969) for double ring infiltration tests and Wooding (1968), using the inverse capillary length term presented by White and Sully (1987) for single ring infiltration tests.

Estimated aquifer property values at infiltrometer test sites along the main channel of San Antonio Creek varied substantially from sites in tributary drainages (fig. 13). Individual site values are shown on figure 13 as circles, the horizontal line within each box represents the median value of all individual site values, and the box itself represents the interquartile range between the $25^{\text {th }}$ percentile (lower bound) and $75^{\text {th }}$ percentile (upper bound) of the data. Estimated streambed hydraulic conductivity at sites along the main channel of San Antonio Creek ranged from 24.8 to 309 feet per day (ft/d) and generally were one order of magnitude
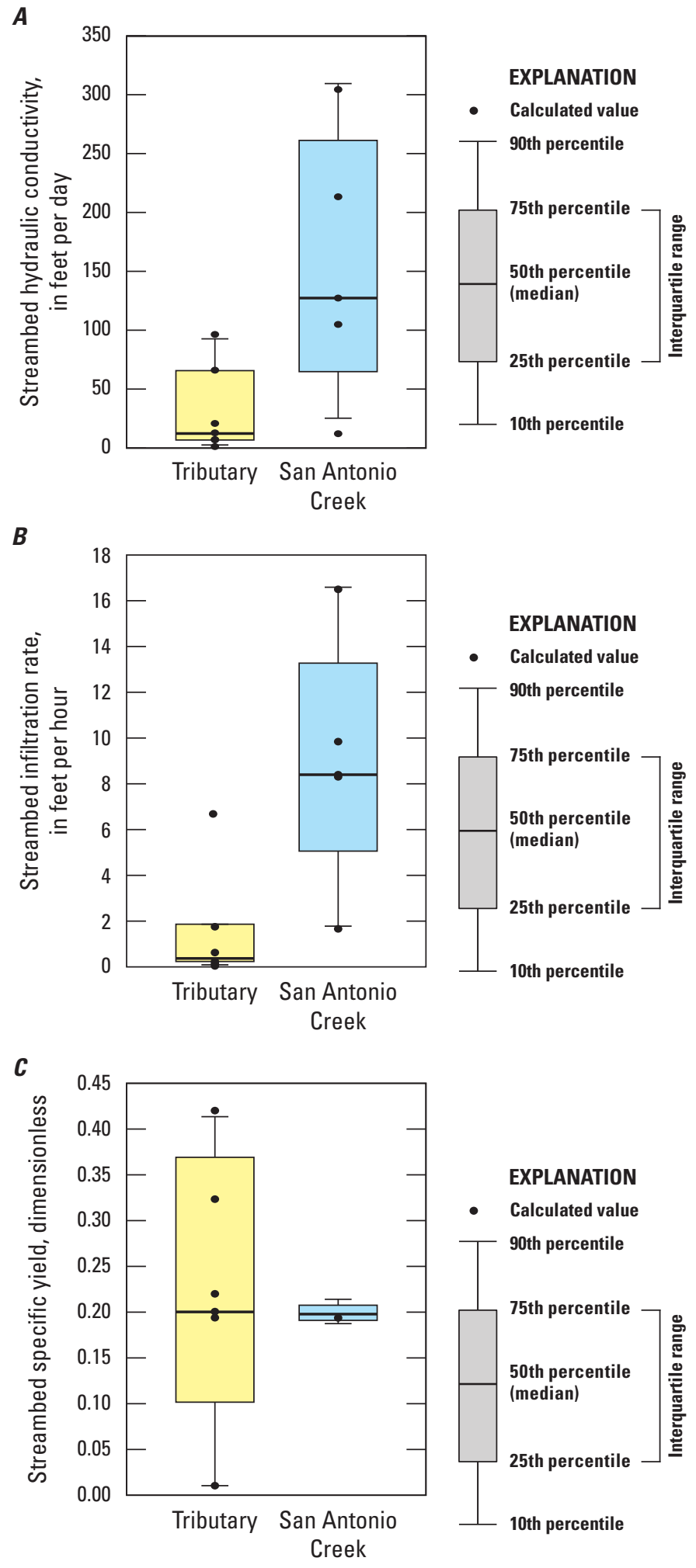

Figure 13. Estimated aquifer properties from streambed infiltrometer test sites along the main channel of San Antonio Creek and tributary streambeds (Ely and others, 2022; U.S. Geological Survey, 2021), San Antonio Creek Valley watershed, Santa Barbara County, California: $A$, streambed hydraulic conductivity; $B$, infiltration rate; and $C$, specific yield. 
Table 5. Estimated aquifer properties from streambed infiltrometer test sites (Ely and others, 2022; U.S. Geological Survey, 2021), San Antonio Creek Valley watershed, Santa Barbara County, California. Site names correspond to locations shown in figure 8.

[USGS, U.S. Geological Survey; mm/dd/yyyy, month/day/year; —, not applicable]

\begin{tabular}{|c|c|c|c|c|c|c|c|}
\hline $\begin{array}{c}\text { Site } \\
\text { name }\end{array}$ & $\begin{array}{c}\text { USGS } \\
\text { station number }\end{array}$ & $\begin{array}{c}\text { Measurement } \\
\text { date } \\
\text { (mm/dd/yyyy) }\end{array}$ & $\begin{array}{c}\text { Streambed } \\
\text { hydraulic } \\
\text { conductivity } \\
\text { (feet/day) }\end{array}$ & $\begin{array}{l}\text { Infiltration } \\
\text { rate } \\
\text { (feet/hour) }\end{array}$ & $\begin{array}{c}\text { Specific yield } \\
\text { (Dimensionless) }\end{array}$ & $\begin{array}{c}\text { Effective } \\
\text { porosity } \\
\text { (Dimensionless) }\end{array}$ & $\begin{array}{l}\text { Field soil } \\
\text { texture }\end{array}$ \\
\hline SAC-STB1 & 344436120161702 & $08 / 23 / 2017$ & 212.88 & 9.8 & 0.19 & 0.194 & Sand \\
\hline SAC-STB2 & 344446120165103 & $08 / 24 / 2017$ & 308.98 & 16.5 & 0.19 & 0.188 & Sand \\
\hline SAC-STB3 & 344521120205602 & $08 / 24 / 2017$ & 127.28 & 8.3 & 0.20 & 0.198 & Sand \\
\hline SAC-STB4 & 344533120233801 & $08 / 24 / 2017$ & 104.60 & 8.3 & 0.20 & 0.199 & Sand \\
\hline SAC-STB5 & 344602120260102 & $08 / 25 / 2017$ & 24.80 & 1.7 & 0.22 & 0.215 & Sandy Clay Loam \\
\hline SAC-UPL1 & 344510120105502 & $08 / 23 / 2017$ & 92.13 & 6.7 & 0.20 & 0.201 & Gravely sandy loam \\
\hline SAC-UPL2 & 344349120164501 & $08 / 22 / 2017$ & 12.08 & 0.3 & - & - & Silty clay loam \\
\hline SAC-UPL3 & 344444120171501 & $08 / 23 / 2017$ & 20.38 & 0.6 & 0.19 & 0.194 & Clay loam \\
\hline SAC-UPL4 & 344652120204601 & 08/24/2017 & 1.92 & 0.1 & 0.32 & ${ }^{1} 0.324$ & Silty clay loam \\
\hline SAC-UPL5 & 344617120254101 & $08 / 25 / 2017$ & 10.26 & 0.3 & 0.42 & ${ }^{1} 0.415$ & Loamy sand \\
\hline SAC-UPL6 & 344530120255401 & $08 / 25 / 2017$ & 65.76 & 1.8 & 0.01 & ${ }^{1} 0.010$ & Sandy Loam \\
\hline SAC-UPL7 & 344843120265601 & $08 / 26 / 2017$ & 6.52 & 0.2 & - & - & Clay loam \\
\hline
\end{tabular}

${ }^{1}$ Effective porosity values for these sites are outside of the normal range of effective porosity for soils.

greater than at sites in tributary drainages (fig. 13A; table 5). The estimated streambed hydraulic conductivity at sites along the tributary drainages ranged from 1.92 to $92.1 \mathrm{ft} / \mathrm{d}$ (fig. 13A; table 5). The highest values of streambed hydraulic conductivity were associated with field soil textures of "sand" at sites along San Antonio Creek in the western part of the SACVW, and the lowest values were associated with field soil textures of "clay," "loam," and "silty clay loam" in tributary drainages in the central part of the SACVW (fig. 8; table 5). The range of estimated streambed infiltration rate at sites along the main channel of San Antonio Creek (1.7 to $16.5 \mathrm{ft}$ per hour $[\mathrm{ft} / \mathrm{hr}]$ ) were also about one order of magnitude greater than for sites in tributary drainages $(0.1$ to $6.7 \mathrm{ft} / \mathrm{hr}$; fig. $13 B$; table 5). Estimated streambed specific yield at sites along the main channel of San Antonio Creek had a substantially smaller range of values $(0.19$ to 0.22$)$ than sites in tributary drainages (0.01 to 0.42 ; fig. $13 C$; table 5 ).

\section{Streambed Electrical Resistivity Instruments}

Streambed instruments that measure electrical resistivity were constructed and installed along the main channel in San Antonio Creek and along tributary streambeds to provide insight into streamflow not recorded by traditional streamgages (fig. 8; table 6). These instruments can record high-resolution temporal and geographic responses of streamflow to precipitation in intermittent streams. The streambed instruments were installed during fall 2015 through spring 2017 and were monitored through spring 2019, or until they were damaged or lost during storm events. Of the 25 instruments deployed, only 18 were recovered. The quality of the data from the recovered instruments was variable and, although promising for selected instruments, were generally not suitable for meaningful interpretations of streamflow in San Antonio Creek or its tributary streams. Examples of two of the best-quality instruments are discussed below.

The streambed instruments used in this study were streambed electrical resistivity sensors (SERS) and Stream Temperature, Intermittency, and Conductivity (STIC; Chapin and others, 2014) loggers. The instruments are small, cost-effective, and can be installed (and re-installed) along stream reaches to measure stream intermittency. Both SERS and STICs employ water contact electrodes to record wet and dry periods - dry periods with no streamflow are characterized by no or small electrical signals, whereas wet periods with streamflow are characterized by large electrical signals when submerged. Twenty SERS and five STICs (hereafter all streambed instruments are referred to as SERS) were deployed inside protective casings level with the streambed and secured to the ground with steel stakes (fig. 1.1). The SERS instruments recorded data in 5- to 15-minute intervals; site visits to download data and maintain the instruments occurred about every six weeks while the instruments were deployed. More information on the construction, installation, and instrument development of SERS and STICs can be found in appendix 1. Measurement data, analysis information, and results are published in a data release (Ely and others, 2022). 
Table 6. Streambed electrical resistivity instrument location information, San Antonio Creek Valley watershed, Santa Barbara County, California.

[USGS; U.S. Geological Survey; SERS, streambed electrical resistivity sensor; STIC, Stream temperature, intermittency, and conductivity instrument; NAVD 88, North American Vertical Datum of 1988]

\begin{tabular}{ccccl}
\hline $\begin{array}{c}\text { Instrument } \\
\text { name }\end{array}$ & $\begin{array}{c}\text { USGS } \\
\text { station number }\end{array}$ & $\begin{array}{c}\text { Land surface } \\
\text { altitude } \\
\text { (NAVD 88) }\end{array}$ & $\begin{array}{c}\text { Instrument } \\
\text { type }\end{array}$ & \multicolumn{1}{c}{$\begin{array}{c}\text { Instrument } \\
\text { location }\end{array}$} \\
\hline SERS-1 & 344510120105501 & 940 & SERS & Tributary stream \\
SERS-2 & 344518120221201 & 403 & SERS & Tributary stream \\
SERS-3 & 344547120253001 & 329 & SERS & San Antonio Creek \\
SERS-4 & 344716120193401 & 403 & SERS & Tributary stream \\
SERS-5 & 344446120165102 & 425 & STIC & San Antonio Creek \\
SERS-6 & 344547120180501 & 604 & SERS & Tributary stream \\
SERS-7 & 344524120174101 & 588 & SERS & Tributary stream \\
SERS-8 & 344441120125002 & 725 & SERS & Tributary stream \\
SERS-9 & 344408120140901 & 670 & SERS & San Antonio Creek \\
SERS-10 & 344436120161602 & 582 & SERS & San Antonio Creek \\
SERS-11 & 344511120192001 & 523 & SERS & San Antonio Creek \\
SERS-12 & 344500120172901 & 548 & SERS & San Antonio Creek \\
SERS-13 & 344602120260101 & 302 & SERS & Tributary stream \\
SERS-14 & 344629120205301 & 521 & STIC & Tributary stream \\
SERS-15 & 344532120233906 & 362 & SERS & San Antonio Creek \\
SERS-16 & 344521120205601 & 424 & STIC & San Antonio Creek \\
SERS-17 & 344613120283601 & 265 & SERS & Tributary stream \\
SERS-18 & 344617120272201 & 280 & SERS & Tributary stream \\
SERS-19 & 344601120260002 & 302 & SERS & San Antonio Creek \\
SERS-20 & 344548120274101 & 305 & SERS & Tributary stream \\
SERS-21 & 344530120225701 & 391 & STIC & San Antonio Creek \\
SERS-22 & 344639120255101 & 322 & SERS & Tributary stream \\
SERS-23 & 344517120190501 & 492 & STIC & Tributary stream \\
SERS-24A & 344839120265501 & 451 & SERS & Tributary stream \\
SERS-24B & 344839120265601 & 451 & SERS & Tributary stream \\
\hline & & & &
\end{tabular}

The measured electrical signals from the SERS instruments were analyzed as percent relative conductivity (PRC), which was calculated for each instrument as:

$$
P R C=\left(\frac{o b s-o b s_{\min }}{o b s_{\max }-o b s_{\min }}\right) \times 100
$$

where

$$
\begin{gathered}
\text { obs is each reading, } \\
o b s_{\min } \text { is the minimum observation for the period of } \\
\text { record, and } \\
o b s_{\max } \quad \begin{array}{c}
\text { is the maximum observation for the period } \\
\text { of record. }
\end{array}
\end{gathered}
$$

Minimum values correspond to time when the instruments were exposed to open air. Maximum values are recorded during periods of streamflow when the presence of water reduces the contact resistance of the instrument. Values between the minimum and maximum range may correspond to times of various amounts of saturation when the instrument is exposed to moisture, either from damp air conditions near the streambed surface, or is the instrument is buried by sediment mobilized by streamflow. The SERS instruments are modified temperature sensors with the thermistor removed and record data as degrees Fahrenheit $\left({ }^{\circ} \mathrm{F}\right)$; negative minimum values are possible because the lower limits of the instruments are below zero. 
Examples of daily PRC for water year 2017 from two SERS instruments (SERS-6 and SERS-3; fig. 8) are shown in figures 14 and 15, respectively, and discussed below. PRC data are shown with daily precipitation recorded at Los Alamos (climate station 204, Los Alamos Fire Station \#24; Santa Barbara County, 2019; figs. 14A, 15A) and daily streamflow recorded at the Los Alamos, Casmalia, and Harris Canyon streamgages (figs. 14B, 15B). Because San Antonio Creek and its tributaries are primarily intermittent streams (fig. 8), they flow only during precipitation events and with little lag time; therefore, PRC data points for days with measured precipitation (rainy-day PRC points) generally would be expected to have higher values than PRC data points for days with no measured precipitation (dry-day PRC points).This generally is true for the examples shown in figures 14 and 15 .
SERS-6 was installed in the eastern part of the SACVW, in a tributary stream about $1 \mathrm{mi}$ north of San Antonio Creek (fig. 8). The daily PRC data show two distinct patterns: between mid-November 2016 and mid-February 2017, the daily PRC data points were generally separated into high (above about 75) and low (below about 25) values; and after mid-February 2017 the PRC data points have a continuous trend of values declining from about 100 to about 60 in June, values of 0 from June to September, and then variable values below 50 through October 2017 (fig. 14A). The change in pattern occurred after a large storm event on February 17-18, 2017. Recorded streamflow at the Casmalia streamgage during this event was $218 \mathrm{ft}^{3} / \mathrm{s}$ (fig. 14B; U.S. Geological Survey, 2021). After this storm, there was no obvious separation of points, and the instrument recorded consistently high PRC values for a period of time (fig. 14A). The high PRC values

$\boldsymbol{A}$

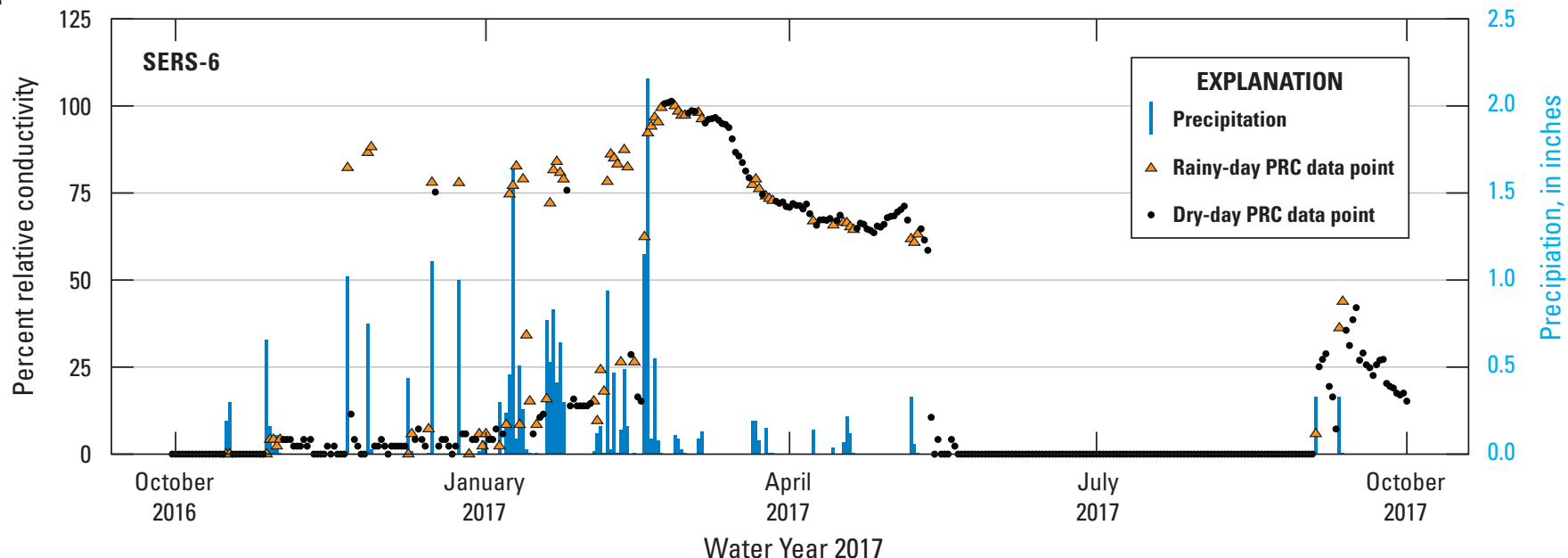

B

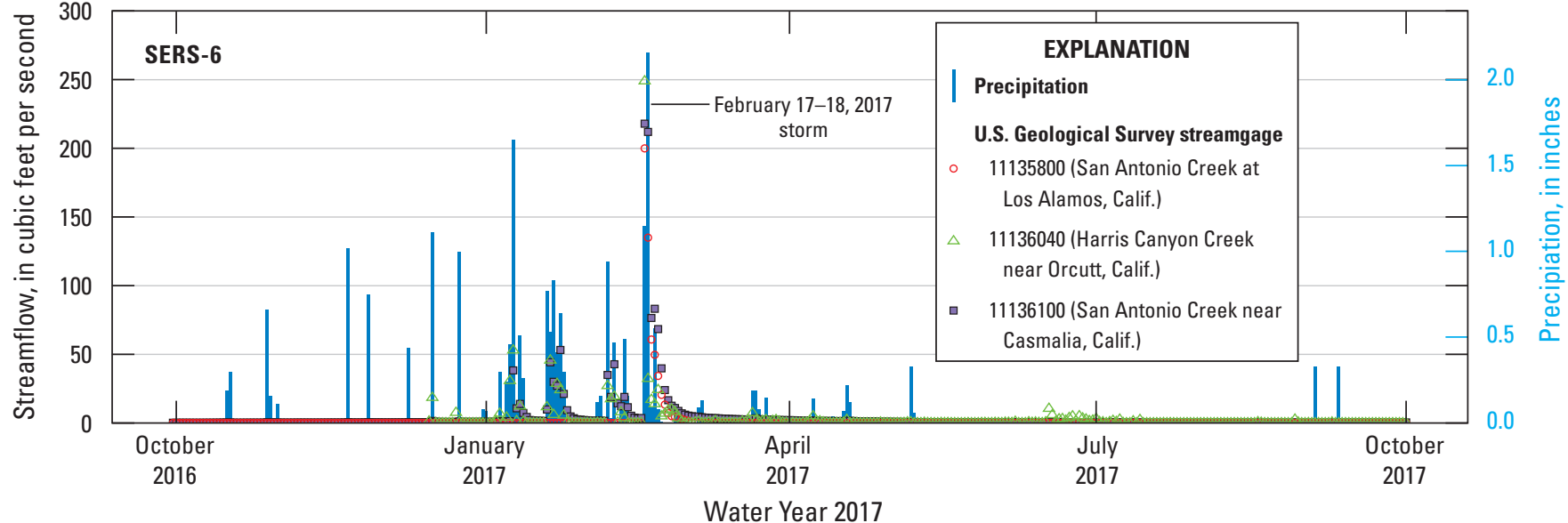

Figure 14. Percent relative conductance (PRC) of streambed electrical resistivity sensor (SERS)-6 compared to $A$, daily precipitation recorded at climate station 204, Los Alamos Fire Station \#24 (Santa Barbara County, 2019); and B, daily streamflow from U.S. Geological survey stations 11135800, 111360460, and 11136100 (U.S. Geological Survey, 2021), San Antonio Creek Valley watershed, Santa Barbara County, California. 
A
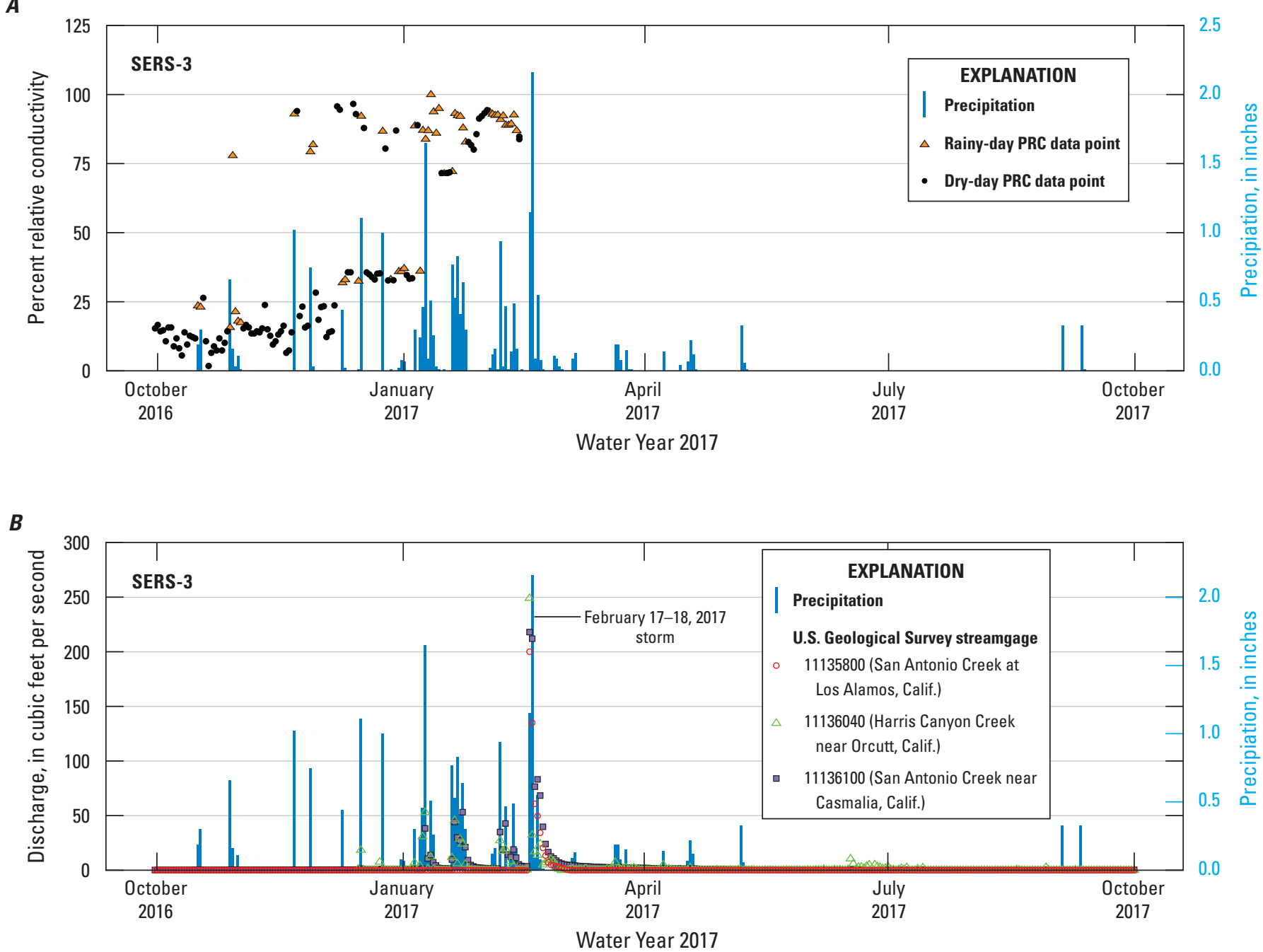

Figure 15. Percent relative conductance (PRC) of streambed electrical resistivity sensor (SERS)-3 compared to $A$, daily precipitation recorded at climate station 204, Los Alamos Fire Station \#24 (Santa Barbara County, 2019); and B, daily streamflow from U.S. Geological survey stations 11135800, 111360460, and 11136100 (U.S. Geological Survey, 2021), Santa Barbara County, California.

following this storm event were likely the result of burial of the instrument beneath sediment mobilized by the storm. Nearby instruments show a separation of PRC data points after this storm, indicating that the pattern observed in SERS-6 was unique to that instrument and not indicative of persistent streamflow in the tributary stream. The February 17-18, 2017, storm event altered, damaged, or buried 14 of the instruments deployed for this study across the SACVW.

The PRC data in SERS-6 prior to the February 17-18, 2017, storm event were separated with values above about 75 , or below about 25 (fig. 14A). The data points with values above 75 are likely indicative of streamflow. All but two of the data points above 75 are rainy-day data points, indicating that streamflow in the tributary stream at which this site is located usually occurred when there was some amount of measurable precipitation. The two PRC values above 75 from dry-day PRC data points could be due to streamflow in the tributary stream following precipitation events or could be due by latent moisture in the air following days with large amounts of precipitation, especially at the streambed-air interface where the instruments are located (fig. 1.1).

SERS-3 was installed in the western part of the SACVW, in the main channel of San Antonio Creek about $1.8 \mathrm{mi}$ east of Barka Slough (fig. 8). The instrument was damaged during the February 17-18, 2017, storm event, therefore daily PRC data points are only available from October 2016 to mid-February 2017 (fig. 15A). Like SERS-6, the daily PRC data points are separated into high (above about 75) and low (below about 25) values, and the high PRC values are likely indicative of streamflow. Unlike SERS-6, however, the high PRC values consist of rainy-day and dry-day data points (fig. 15A), indicating that streamflow at this site occurred on days with and without measurable precipitation. The regular occurrence of dry-day PRC data points with values above 75 
indicates that streamflow is likely to occur along this reach of San Antonio Creek on days where there is no measurable precipitation, possibly flowing for several days following precipitation events.

\section{Geology and Structure}

The SACVW sits between two regional tectonic provinces, the Transverse Ranges to the south (Santa Ynez Mountains) and the California Coast Ranges to the north and east (San Rafael Mountains; fig. 1). Tectonic convergence between these two provinces produced a series of west-northwest trending anticlinal, synclinal, and fault structures (Dibblee, 1950; Muir, 1964; Namson and Davis, 1990) that are present in the SACVW. The primary geologic structure in the SACVW is the Los Alamos syncline, a west-east trending fold that downfolds and preserves the upper, younger part of the geologic section along the axis of the SACVW (fig. 16). The Los Alamos syncline is flanked by anticlinal structures that result in uplifted bedrock that bounds the southern edge of the basin in the Purisima Hills and bounds the north side of the basin in the Casmalia and Solomon Hills (fig. 16). The Los Alamos syncline plunges east-southeast, resulting in older bedrock units that wrap around the synclinal axis near the western edge of the SACVW, and along the northern and southern boundaries (fig. 16). These upfolded consolidated bedrock outcrops locally impede groundwater flow, resulting in the formation of Barka Slough through groundwater upwelling (Muir, 1964).

\section{Geologic Units}

The SACVW is underlain by consolidated sedimentary rocks and filled with poorly consolidated to unconsolidated basin-fill materials (fig. 16). Consolidated sedimentary rocks include the Miocene to Pliocene Monterey Shale, Sisquoc Formation, and Foxen Mudstone which are combined and shown as a single undifferentiated unit ("consolidated bedrock") in figure 16. Stratigraphically above the consolidated bedrock are poorly consolidated to unconsolidated basin-fill sedimentary materials that include, from oldest to youngest, the upper Pliocene Careaga Sandstone, the early Pleistocene and upper Pliocene Paso Robles Formation, the Pleistocene Orcutt Sand, Pleistocene to recent terrace and alluvial deposits, and young surficial sediments (Woodring and Bramlette, 1950; Dibblee and Ehrenspeck, 1988, 1989, 1993a, b; Dibblee and others, 1994a, b; Sweetkind and others, 2021; fig. 16). The Orcutt Sand and terrace and alluvial deposits are limited in extent and are mapped as part of the Paso Robles Formation and old alluvium on figure 16. Young surficial sediments are labeled as channel alluvium in figure 16.
The Careaga Sandstone is a shallow marine sandstone (Muir, 1964; Dibblee and Ehrenspeck, 1988, 1989, 1993a, b; Dibblee and others, 1994a, b). The Paso Robles Formation is unconsolidated non-marine clayey sand with scattered pebbles and lenses of pebble and cobble gravel with white siliceous shale clasts of the Monterey Shale (Dibblee and Ehrenspeck, 1988, 1989, 1993a, b; Dibblee and others, 1994a, b). The Paso Robles Formation includes discontinuous beds of pebbly sand, clay, and freshwater limestone, including a thin layer of light gray to tan pebbly sand with freshwater marly limestone and shale stratigraphically dissects the formation (mapped as a sub-unit of the Paso Robles Formation with map-unit abbreviation QTps by Dibblee and Ehrenspeck [1988, 1993a] and Dibblee and others [1994a]; fig. 16). The Orcutt Sand, and terrace and alluvial deposits mapped as part of the Paso Robles Formation (fig. 16), are geographically limited remnants of weakly consolidated, non-marine alluvial and wind-blown sands and gravels (Dibblee and others, 1994a). Channel alluvium are unconsolidated deposits of gravel, sand, and clay and are present along San Antonio Creek and its major tributaries.

\section{Geologic Structure}

The geologic structure of the SACVW is generally controlled by the Los Alamos syncline, a west-east trending fold that plunges to the east-southeast. The Los Alamos syncline, and associated faults and subparallel anticlinal and synclinal folds, deform the consolidated bedrock sedimentary materials and downfold and preserve the upper, younger part of the geologic section along the axis of the SACVW. Borehole data have shown that the basin-fill sedimentary materials are nearly 3,000 feet thick in the center of the basin to the west of the town of Los Alamos and rapidly decreases in thickness toward the basin margins (Hutchinson, 1980). Anticlinally folded consolidated bedrock is uplifted at the southern edge of the basin in the Purisima Hills and at the northern edge of the basin in the Casmalia and Solomon Hills (fig. 16). Surface geologic maps show that younger basin-fill sedimentary units are steeply north-dipping to vertical and locally overturned along the southern basin margin (Muir, 1964; Martin, 1985; Dibblee and Ehrenspeck, 1988, 1989, 1993a, b; Dibblee and others, 1994a, b). Strata on the north margin of the basin dip moderately to the south, as does the consolidated bedrock surface, toward the basin axis (Muir, 1964; Martin, 1985). At the western edge of the SACVW, upfolded consolidated bedrock at land surface and at shallow depths locally impedes groundwater flow, resulting in the formation of the Barka Slough through groundwater upwelling (Muir, 1964). The complexity of the top of consolidated bedrock surface reflects the prolonged and complicated tectonic history and structural development of the SACVW that affected the older rocks (Woodring and Bramlette, 1950; Namson and Davis, 1990). 


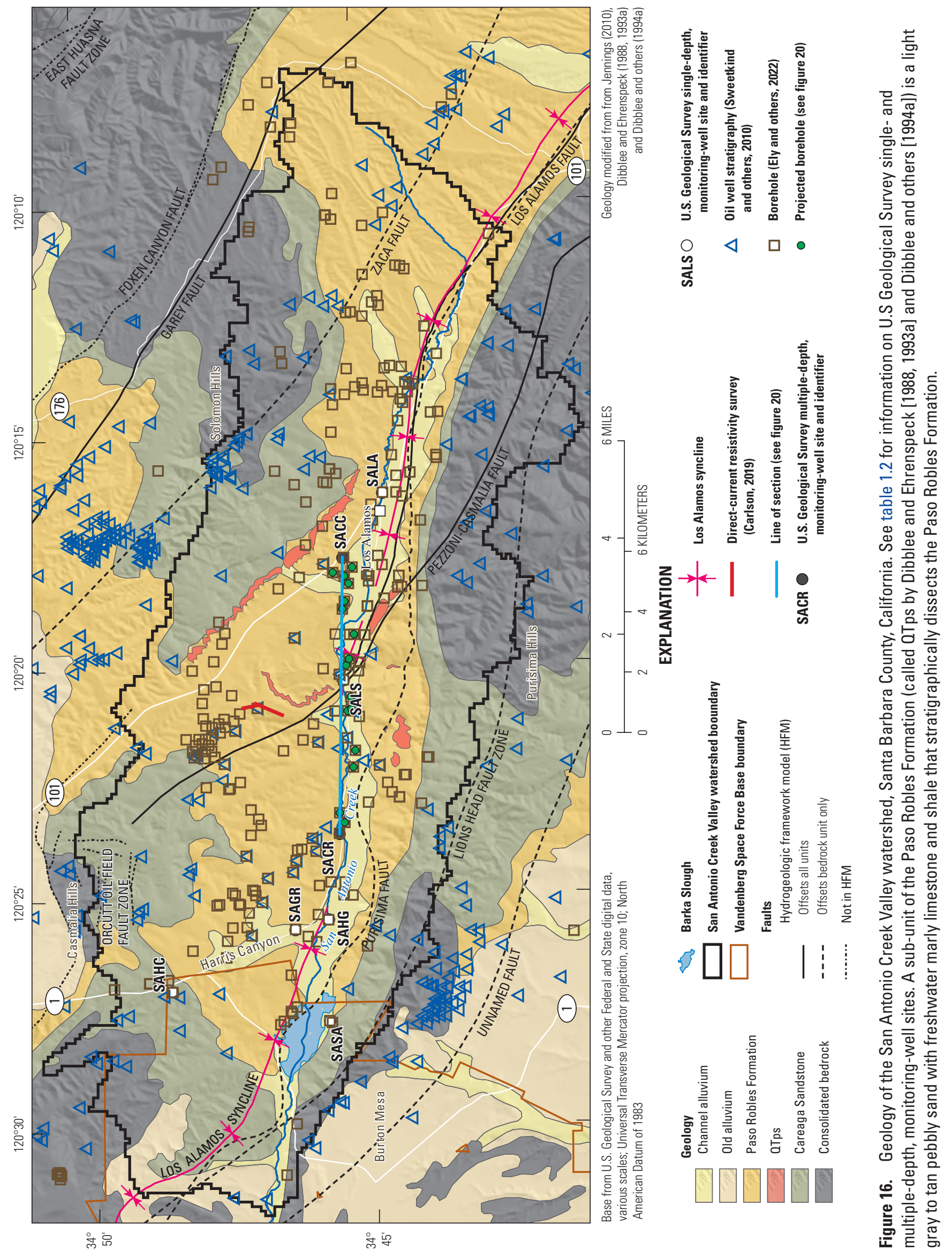




\section{Faults}

Numerous faults have been mapped in the vicinity of the SACVW (fig. 16); several older faults, such as the Zaca, Purisima, and Lions Head faults, and one unnamed fault, are likely to only offset the consolidated bedrock (fig. 16; Sweetkind and others, 2021). Three faults, the Quaternary Pezzoni-Casmalia, Los Alamos, and Garey faults (U.S. Geological Survey and California Geological Survey, 2019; fig. 15), potentially offset the younger, basin-fill sedimentary units based on evidence of fault recency and proximity to basin-center. Other Quaternary faults in the vicinity of the SACVW include the Foxen Canyon fault, the East Huasna fault zone, and the Orcutt Oil Field fault zone (U.S. Geological Survey and California Geological Survey, 2019); these faults likely do not substantially offset the younger basin-fill sedimentary units.

\section{Hydrogeologic Framework Model}

To develop the necessary hydrogeologic understanding from the mapped geology, a 3D HFM of the SACVW was developed from geologic, geophysical, and hydrologic data. The HFM is a digital representation of thickness and extent of hydrogeologic units that comprise the aquifer system and the geometry of hydrogeologically and structurally important folds and faults as interpreted from input data and from a conceptual understanding of the geology. The HFM was constructed by compiling surface and subsurface hydrogeologic data as point data and using geologic-modeling software to interpolate three-dimensional surface horizons and volumes of each hydrogeologic unit. The HFM comprises six hydrogeologic units: one basal bedrock unit and five basin-fill sedimentary units. The previously described geologic units (fig. 16) were classified into six hydrogeologic units (fig. 17) that represent the aquifer system. The six units from bottom to top (oldest to youngest) are (1) consolidated bedrockcomprised of Miocene to Pliocene Monterey Shale, Sisquoc Formation, and Foxen Mudstone, (2) Careaga Sandstonecomprising the Pliocene geologic formation of the same name, (3) lower Paso Robles Formation, (4) middle Paso Robles Formation, (5) upper Paso Robles Formation-comprising informal members of the Pleistocene and Pliocene Paso Robles Formation (see "Subdivision of the Paso Robles Formation" section below), and (6) channel alluviumcomprising the young, unconsolidated deposits along San Antonio Creek and its tributaries. The resulting HFM is consistent with geologic concepts and the geologic history of the area.

\section{Data Sources}

Surface and subsurface geologic data were used to derive the geometry, thickness, and extent of the hydrogeologic units in the SACVW. Geologic map data were compiled from Woodring and Bramlette (1950), Muir (1964), Tennyson and others (1995), Dibblee and Ehrenspeck (1988, 1989, 1993a, b), Dibblee and others (1994a, b), and Jennings (2010). Surface-fault traces were compiled from these geologic maps and from the Quaternary Fault and Fold Database of the United States (fig. 16; U.S. Geological Survey and California Geological Survey, 2019). Ground-based direct-current resistivity surveys were performed in the north-central portion of the study area (fig. 16); the geophysical data from these surveys were interpolated as two-dimensional profiles of the electrical resistivity structure of subsurface materials down to about 650 feet below land surface (bls; Carlson, 2019). Lithologic and geophysical logs were compiled from 247 boreholes (fig. 16; Ely and others, 2022), including logs from water wells that were obtained from the California Department of Water Resources Well Completion Report database (https://water.ca.gov/Programs/Groundwater-Management/ Wells/Well-Completion-Reports), the USGS National Water Information System (NWIS: https://waterdata.usgs.gov/nwis; U.S. Geological Survey, 2021), and oil and gas well from the California Geologic Energy Management Division (CalGEM; https://www.conservation.ca.gov/calgem/Pages/ WellFinder.aspx). Additional stratigraphic information from oil wells were compiled from the tabulation of Sweetkind and others (2010; fig. 16).

Two multiple-depth, monitoring-well sites (SACR and SACC) and six single-depth, monitoring-well sites (SAHC, SASA, SAGR, SACR, SALS, and SALA) were drilled by the USGS along the main east-west axis of the SACVW and in Harris Canyon (figs. 16, 17; table 1.2). More information on the installation, drilling, and construction of each well site can be found in appendix 1 and in the USGS GeoLog Locator (U.S Geological Survey, 2018). Hydrogeologic data collected from these well-sites include detailed descriptions of drill cuttings, a suite of geophysical log measurements (fig. 18), aquifer slug tests (see "Definition of the Aquifer System" section), and discrete and continuous groundwater-level measurements (fig. 19; see "Long-Term Trends in Groundwater Levels" section). Compiled well data, including locations, well construction, and standardized lithology depth-interval information are available in a data release (Ely and others, 2022) 


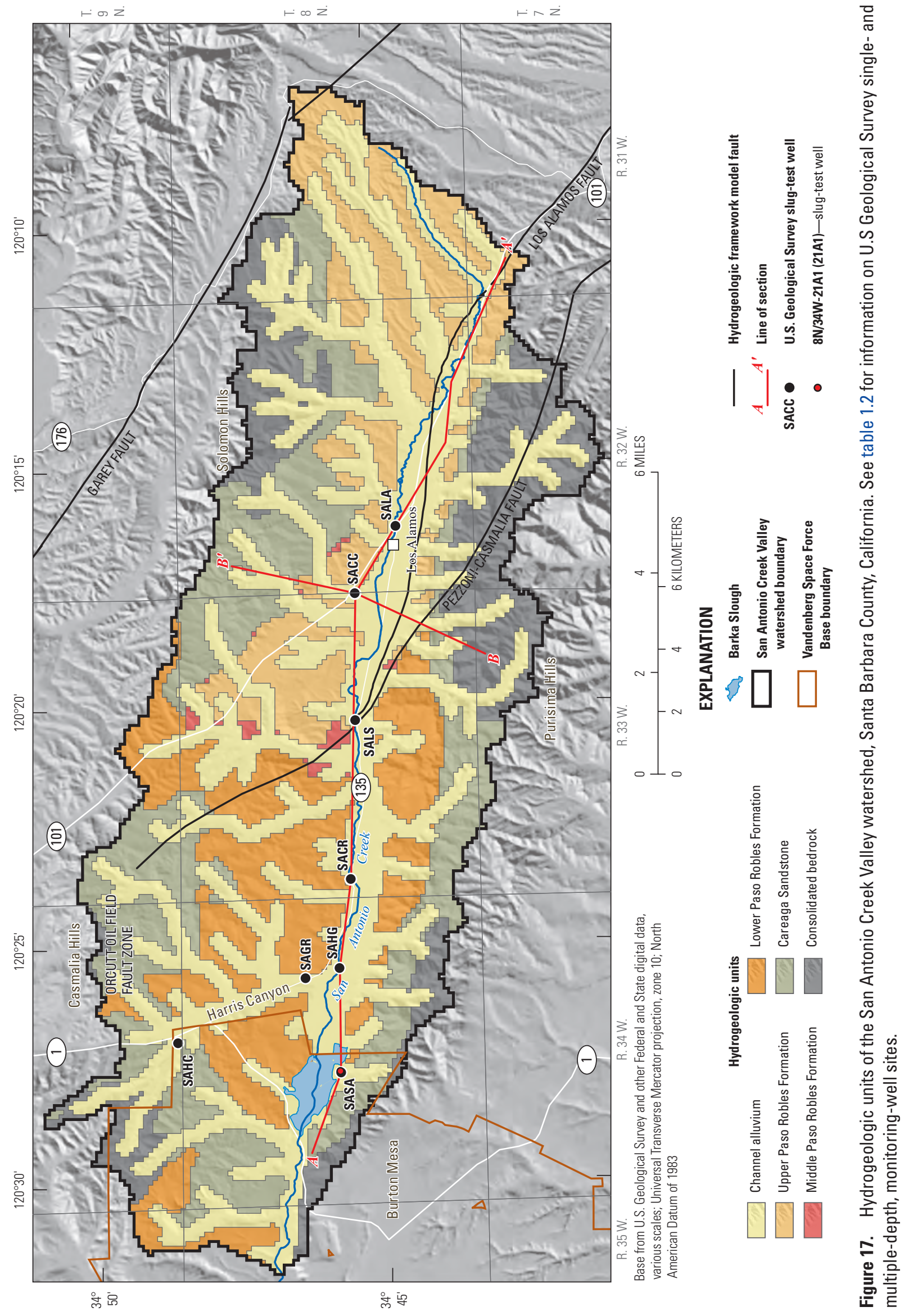




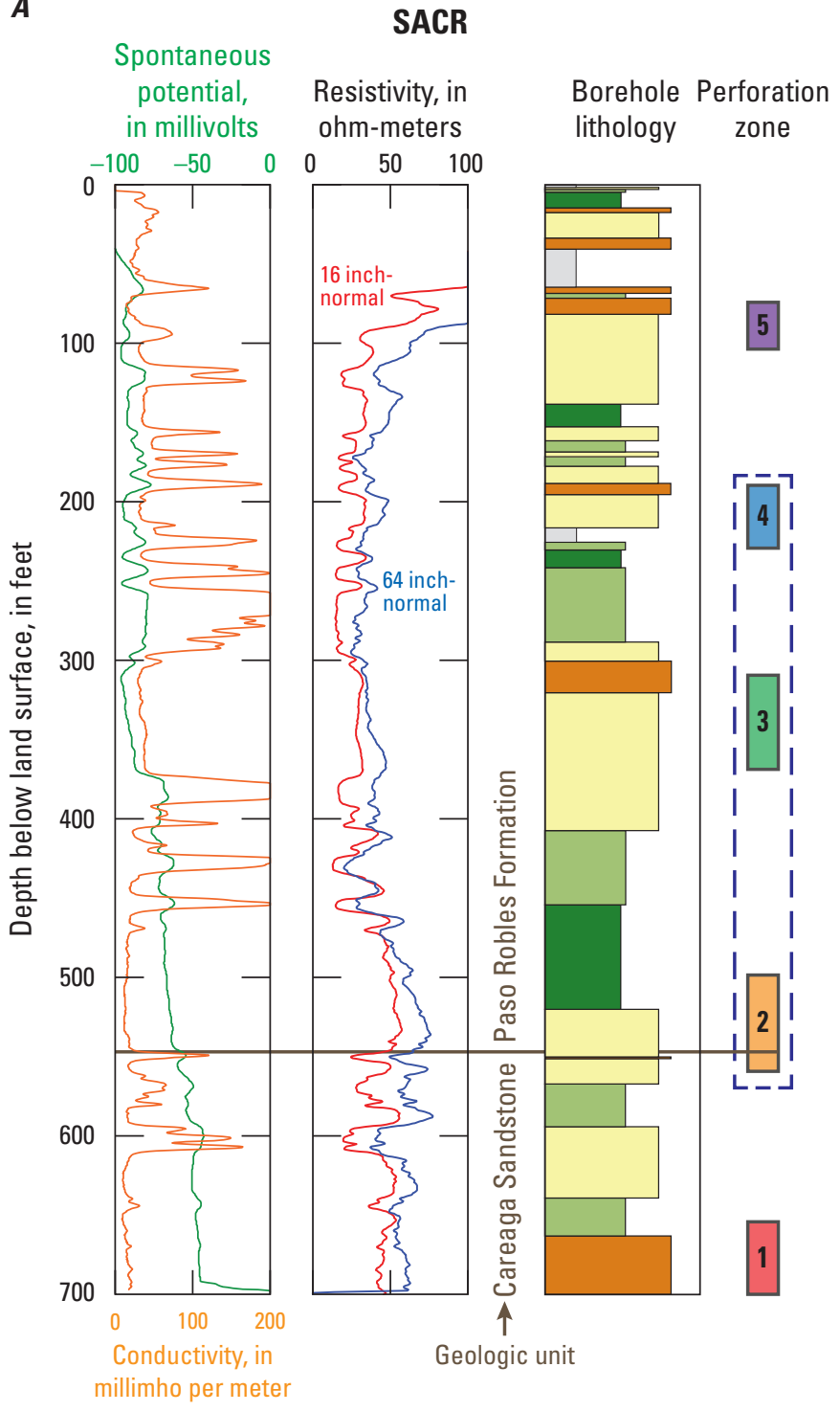

B

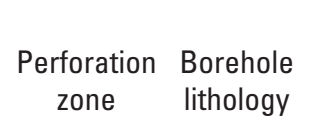

SACC

potential,

in millivolts

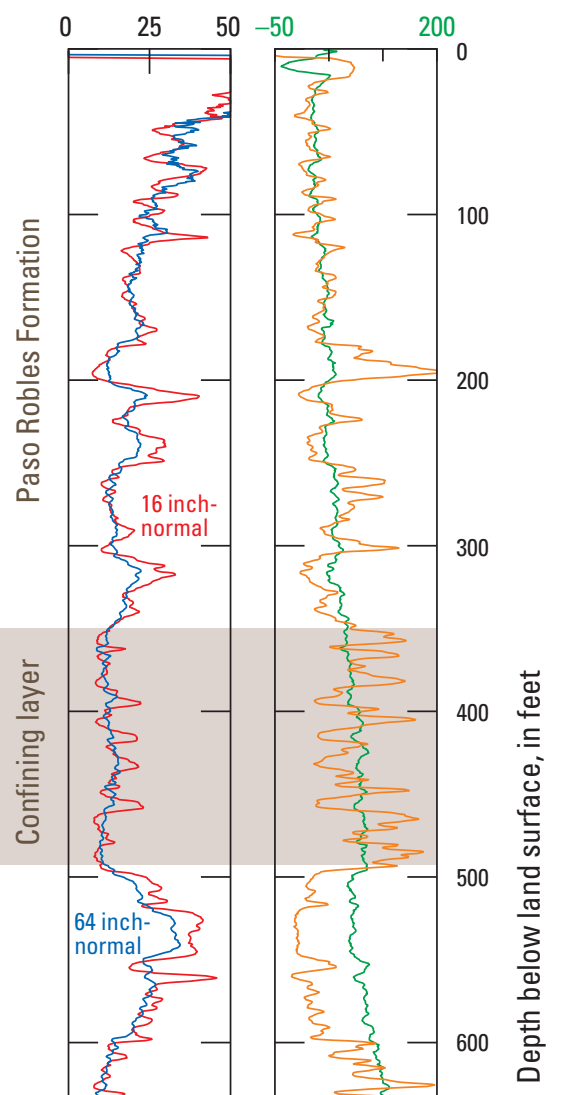

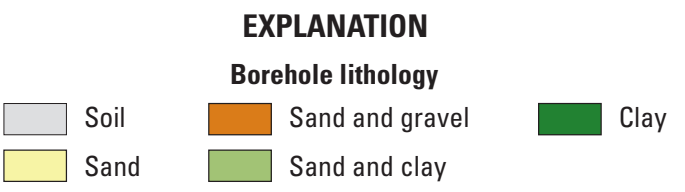

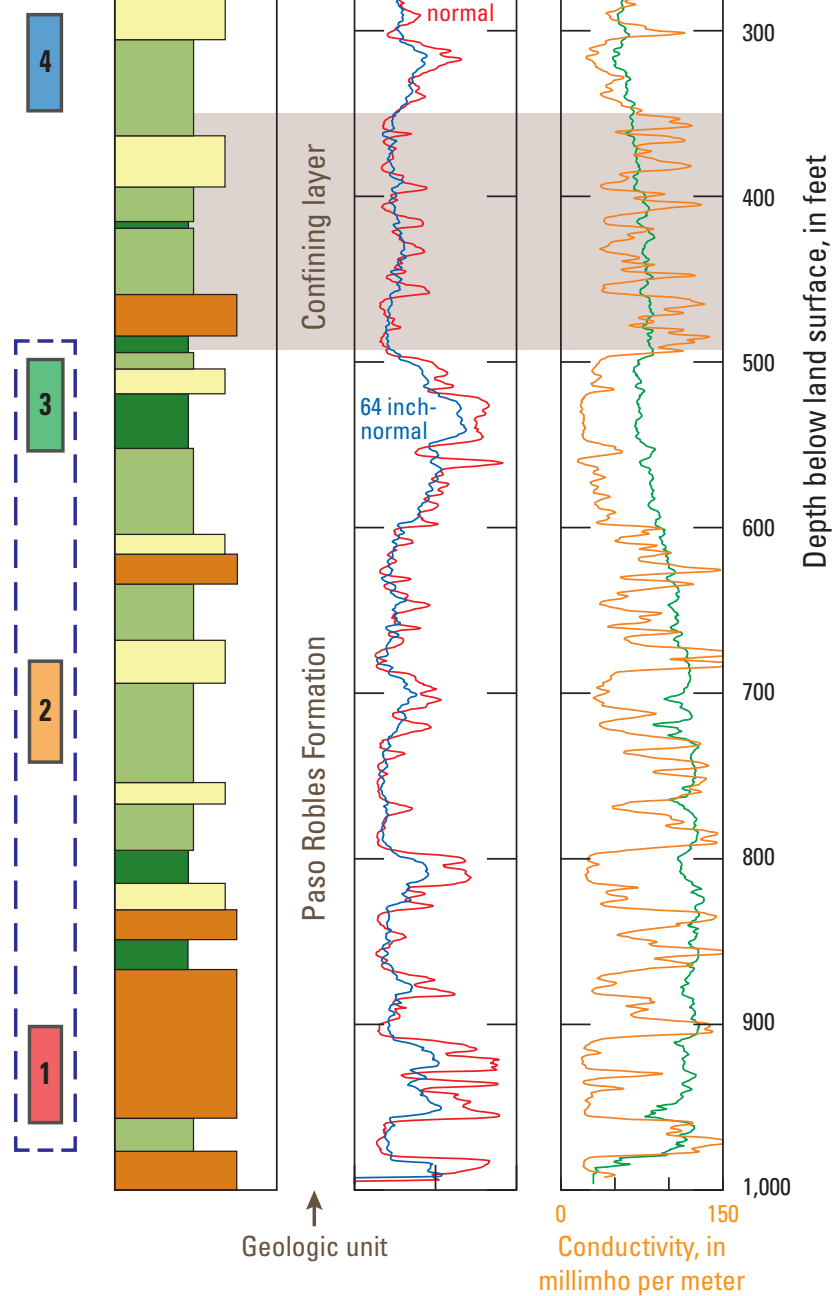

Figure 18. Borehole lithology and geophysical logs for U.S. Geological Survey multiple-depth, monitoring-well sites $A$, SACR, and $B$, SACC (appendix 1; table 1.2; U.S. Geological Survey, 2018), San Antonio Creek Valley watershed, Santa Barbara County, California. Dashed blue boxes indicate hydraulically connected aquifer intervals. 
$\boldsymbol{A}$

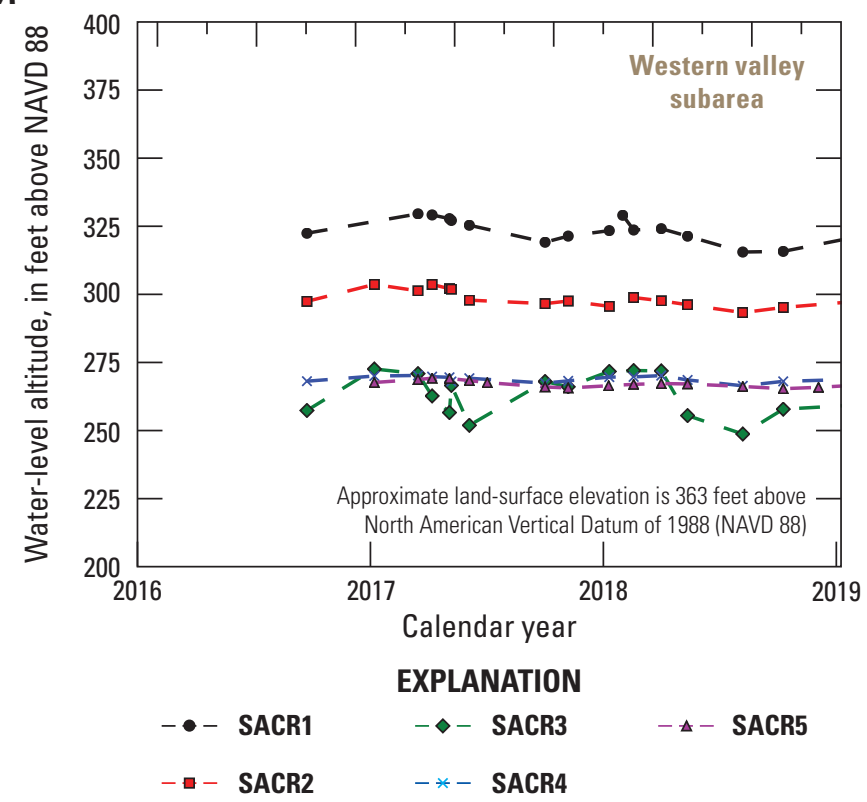

$B$

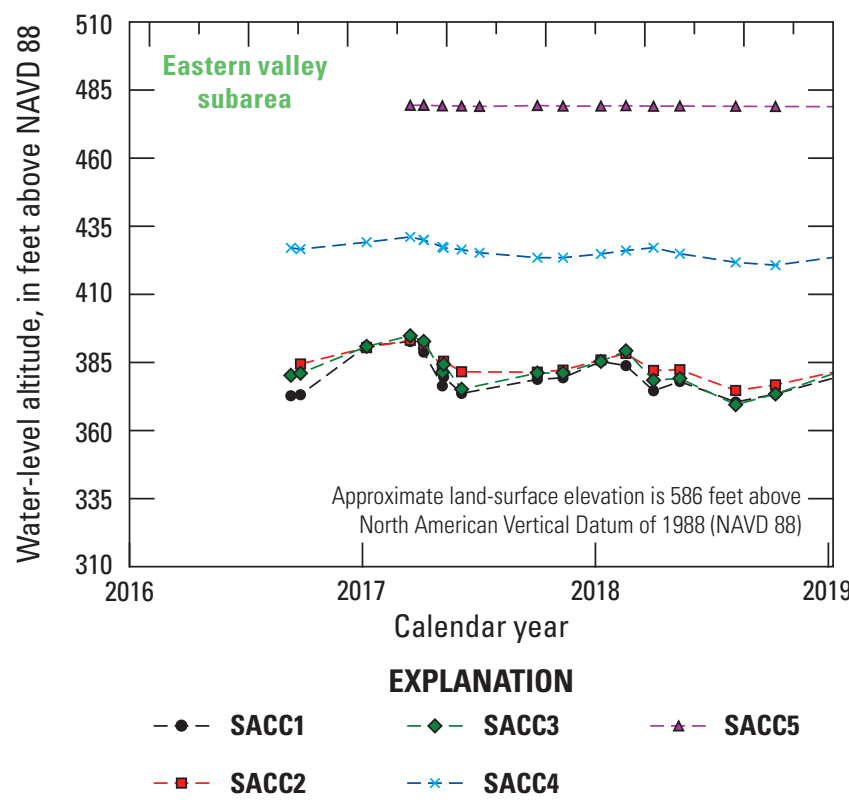

Figure 19. Measured groundwater elevations during 2016-18 for U.S Geological Survey multiple-depth, monitoring-well sites A, SACR, and B, SACC (table 1.2; U.S. Geological Survey, 2021), San Antonio Creek Valley watershed, Santa Barbara County, California.

\section{Subsurface Hydrogeologic Interpretation}

Interpretation of the geometry, thickness, and extent of the hydrogeologic units was an iterative process based on the conceptual understanding of SACVW geology and the input data described earlier. The structural conceptualization developed in previous studies of the basin (Woodring and Bramlette, 1950; Hutchinson, 1980; Martin; 1985) were incorporated into this study and used as guides from which interpretations of subsurface data were derived. Geologic maps, drillers' lithology log descriptions, and geophysical logs were the primary data sources used to interpret subsurface hydrogeologic units. Interpretation of these data was generally a two-step procedure: (1) hydrogeologic units were identified and characterized in the two USGS multiple-depth, monitoring-well sites, where high-quality lithology descriptions, geophysical logs, physical-sample material, and groundwater-level data allowed for high-confidence interpretations and descriptions of each unit and (2) hydrogeologic units identified in the multiple-depth, monitoring-well sites were correlated to other boreholes throughout the subsurface of the SACVW using drillers' $\log$ descriptions, geophysical logs, and geologic-map data Subsurface data points of consolidated bedrock were derived from stratigraphic information tabulated by Sweetkind and others (2010; fig. 16). Subsurface data points for the basin-fill hydrogeologic units were derived from drillers' $\log$ descriptions and geophysical logs from water wells, oil wells, and USGS monitoring-well sites, groundwater-level measurements from USGS multiple-depth, monitoring-well sites, structural contours of the Careaga Sandstone and middle Paso Robles Formation, and previously published geologic sections of the channel alluvium.

\section{Subdivision of the Paso Robles Formation}

The Paso Robles Formation was subdivided into three informal members: lower, middle, and upper (fig. 17). The lower and upper members were interpreted to consist of more coarse-grained sediment, and the middle member was interpreted to consist of fine-grained sediment and act as a confining layer where present. Initial interpretation of the three members was based on analysis of drillers' log descriptions, geophysical logs, and groundwater-level measurements from USGS multiple-depth, monitoring-well sites SACR and SACC (figs. 18, 19); initial interpretations were corroborated using compiled subsurface information from other water wells and oil wells.

Drilling at USGS multiple-depth, monitoring-well sites, SACR and SACC, was initiated in the Paso Robles Formation (fig. 16). SACR was interpreted to intersect the Careaga Sandstone at a depth of about 550 feet bls based on the appearance of very fine-grained sand with shell fragments, and geophysical log data that indicate the presence of well-sorted, fine-grained material (fig. 18A; U.S. Geological Survey, 2018). In contrast, SACC was interpreted to be drilled entirely within the Paso Robles Formation (fig. 18B). The lithologies at each site within the interpreted Paso Robles Formation were generally heterogeneous, with multiple coarse-grained and fine-grained intervals apparent in the lithologic and geophysical logs (fig. 18). In SACR, the 
deepest well (SACR1) was completed within the Careaga Sandstone, and the remaining four wells were completed in the Paso Robles Formation (fig. 18A). SACR2, SACR3, and SACR4 had groundwater elevations that fluctuated through time, indicating a response to nearby groundwater pumping and a connected aquifer system across these depth intervals (fig. 19A). Groundwater-level differences between wells SACR2 and SACR4 indicated an upward vertical gradient (deep to shallow) from SACR2 to SACR3 to SACR4 within the Paso Robles Formation (fig. 19A). Groundwater levels between SACR1 and SACR2 indicated an upward vertical gradient (deep to shallow) between the Careaga Sandstone and overlying Paso Robles Formation.

Hydrographs from wells at SACC show a distinct difference in measured groundwater levels between the three deepest wells (SACC1, SACC2, and SACC3) and the two shallow wells (SACC4 and SACC5; fig. 19B). The three deepest wells had similar groundwater elevations and similar fluctuations through time, indicating a response to nearby pumping and a connected aquifer system across this depth interval. In contrast, the two shallow wells had groundwater elevations that were about 40 and $100 \mathrm{ft}$ higher than levels in the deep wells, and had little fluctuations over time, indicating a muted response to nearby pumping (fig. 19B). Groundwater-level differences between the wells at SACC indicate a downward vertical gradient (from shallow to deep), and the different responses to pumping between the upper two and lower three wells indicate that they are hydraulically isolated from each other. This isolation is interpreted to primarily occur across about a 150 -foot-thick, fine-grained layer identified in the drill cuttings and on the geophysical logs between wells SACC3 and SACC4 (fig. 18B).

Defining the extent of the intra-Paso Robles Formation fine-grained layer that was identified within borehole SACC was essential to understanding the hydrogeology of the SACVW. If found to be extensive, this layer could act as a barrier to vertical groundwater flow across the SACVW. Geologic maps show thin limestone beds within the Paso Robles Formation that are at least locally continuous (Woodring and Bramlette, 1950; mapped unit QTps of Dibblee and Ehrenspeck [1988, 1993a] and Dibblee and others [1994a]; fig. 16). These limestones are known to be associated with shale horizons at the base of the Paso Robles Formation and locally elsewhere in the unit (Woodring and Bramlette, 1950). The fine-grained layer penetrated in SACC (fig. 18B), and the thin limestone plus shale horizons mapped in outcrop as QTps (fig. 16), are interpreted to be one or more fine-grained terrestrial sediment intervals within the Paso Robles Formation, possibly representing a lacustrine deposit.

Single-depth, monitoring-well site SALS is located along San Antonio Creek where the mapped outcrop of unit QTps crosses the valley (fig. 16). The well penetrated abundant clay and silt, with trace gravels, to a depth of 60 feet bls (U.S. Geological Survey, 2018; Ely and others,
2022). A conceptual east-west section from SACR to SACC shows the interpreted subsurface configuration of basin-fill hydrostratigraphy and lithology (fig. 20). The top of Careaga Sandstone in this section was drawn from the contact in SACR (fig. 18A), an interpreted structural contour of the top of the Careaga Sandstone, and compiled elevations of the top of the Careaga Sandstone from the stratigraphic data tabulation of Sweetkind and others (2010). Lithologic data from nearby water wells were projected onto the section (Ely and others, 2022). The Paso Robles Formation was divided into informal lower, middle, and upper units based on drillers' lithology logs and hydraulic data from SACC and SACR (fig. 20). The middle unit was interpreted as a near-continuous fine-grained interval connecting the fine-grained interval intercepted in SACC with the mapped outcrop of fine-grained unit QTps near monitoring well SALS. The lower and upper units were relatively coarse grained and consisted of substantial sequences of sands and gravels with interbedded fine-grained layers. In general, site SACR penetrates intervals in the Paso Robles Formation that are stratigraphically below most of the section sampled by SACC (fig. 20).

\section{Framework Model Construction and Results}

Digital datasets representing the top of each hydrogeologic unit were compiled as input data for the HFM (see "Data Sources" section above). Each hydrogeologic unit dataset contains outcrop information from geologic maps, subsurface picks from drillers' lithology logs and geophysical logs, and reported stratigraphic picks from oil wells; datasets for selected units also contain structural contours.

Digital fault data for the HFM were created by generating a set of horizontal (x,y) and vertical (z) data points along each surface fault trace and determining $\mathrm{x}, \mathrm{y}$, and $\mathrm{z}$ at depth from the fault dip-angle and dip-direction. The dip-angle for all faults was assumed to be vertical; however, the faults were incorporated into the HFM with 85-degree dip angles because of limitations of the geologic modeling software. The older Zaca, Purisima, and Lions Head faults, and the one unnamed fault, are likely to only offset the consolidated bedrock (Sweetkind and others, 2021); therefore, these faults were only used to constrain the structure of the consolidated bedrock in the HFM (labeled as figs. 16 and 21). The Quaternary Pezzoni-Casmalia, Los Alamos, and Garey faults are likely to offset the consolidated bedrock unit and the younger, basin-fill hydrogeologic units based on evidence of fault recency and proximity to basin-center (U.S. Geological Survey and California Geological Survey, 2019; figs. 16, 17). These faults were used in the HFM to constrain the structure of all units in the HFM. The Foxen Canyon fault, the East Huasna fault, and the Orcutt Oil Field fault zone (fig. 16) were not included in the HFM. 


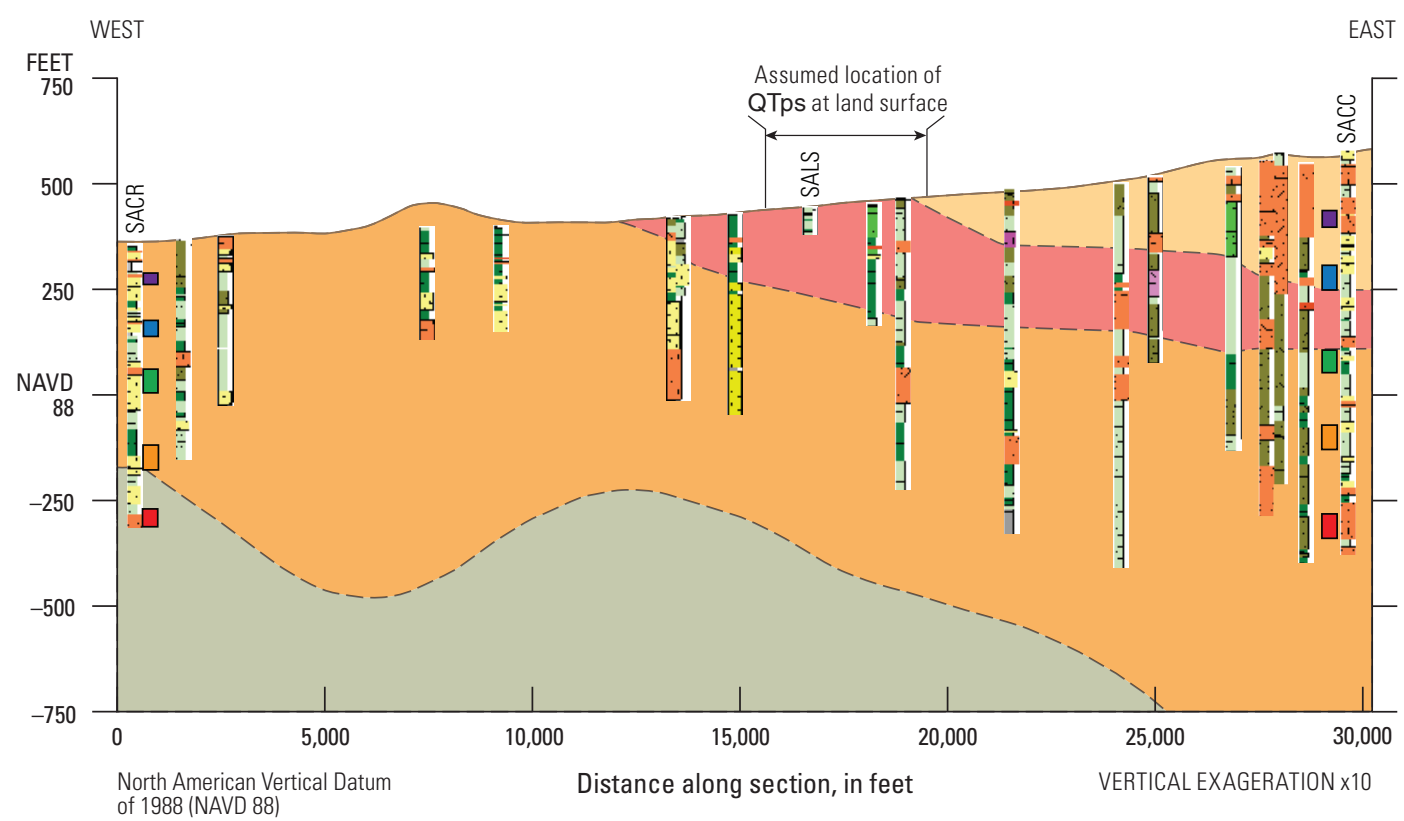

EXPLANATION
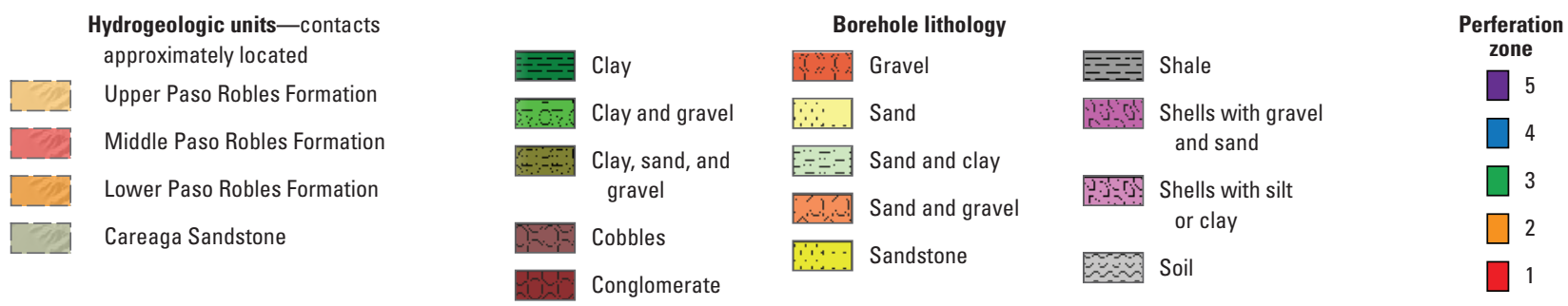

Figure 20. Conceptual hydrogeologic section between U.S. Geological Survey multiple-depth, monitoring-well sites SACR and SACC, San Antonio Creek Valley watershed, Santa Barbara County, California. See table 1.2 for information on U.S Geological Survey single- and multiple-depth, monitoring-well sites. A sub-unit of the Paso Robles Formation (called QTps by Dibblee and Ehrenspeck [1988, 1993a] and Dibblee and others [1994a]) is a light gray to tan pebbly sand with freshwater marly limestone and shale that stratigraphically dissects the Paso Robles Formation. Borehole lithology logs projected onto the section are shown in figure 16; the outcrop of QTps shown in this figure is projected from figure 16.

The mapped locations of the Pezzoni-Casmalia and Los Alamos faults from the Quaternary Fault and Folds Database of the United States (figs. 16, 17; U.S. Geological Survey and California Geological Survey, 2019) are based on inferred locations reported by Sylvester and Darrow (1979) even though these faults are not identifiable at land surface (Sweetkind and others, 2021). Although there is no evidence of these faults at land surface, these structures could be present at depth and therefore are included in the HFM as mapped by the U.S. Geological Survey and California Geological Survey (2019; figs. 16, 17). Additional work was not completed in this study to verify the existence or location of these faults.

The HFM was built using EarthVision, a 3D geologic-modeling software package (Dynamic Graphics, Inc., 2021). EarthVision uses a biharmonic cubic-spline algorithm that utilizes a minimum-tension (minimum curvature) gridding technique designed to generate horizon grids from
3D point data (Dynamic Graphics, Inc., 2021), such as the hydrogeologic unit datasets described earlier. Grid spacing of all hydrogeologic unit horizons was $492.1 \mathrm{ft}$ in the $\mathrm{x}$ and $\mathrm{y}$ horizontal directions. Each hydrogeologic unit horizon grid was constructed in stratigraphic order from oldest (deepest) to youngest (most shallow), and subsequently younger horizons were built on top of previously constructed horizon grids. The total thickness of each hydrogeologic unit was defined as the difference between a given unit horizon and the upper surface of the unit horizon below. Finally, all horizon grids were clipped at land surface using a discretized digital elevation model (DEM) grid based on the National Elevation Dataset 10-meter DEM (U.S. Geological Survey, 2013).

In EarthVision, the HFM was formed from a set of independent blocks (called fault blocks) that represented hydrogeologic materials within a particular volume defined by faults. Horizon tops were interpolated independently for 


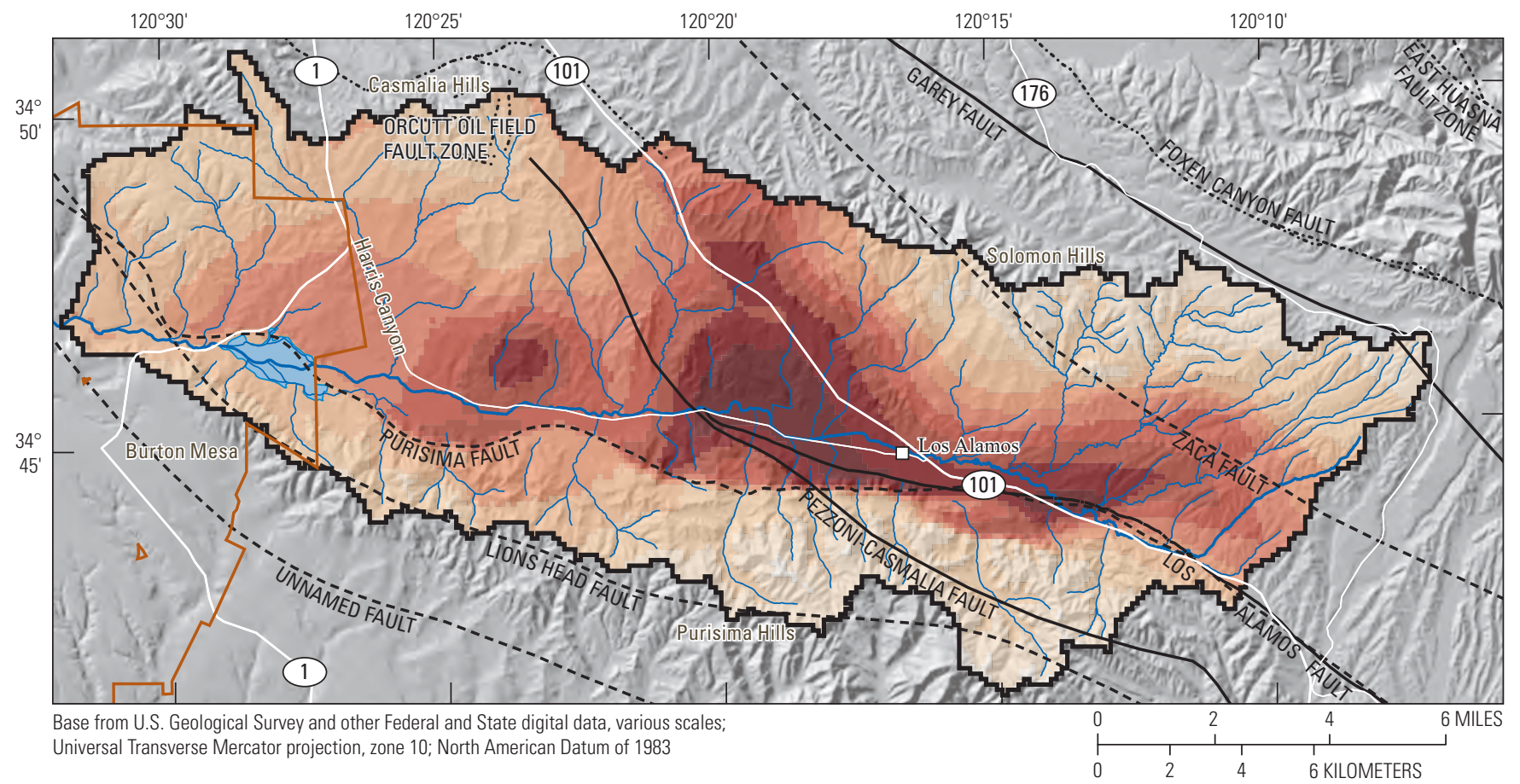

EXPLANATION
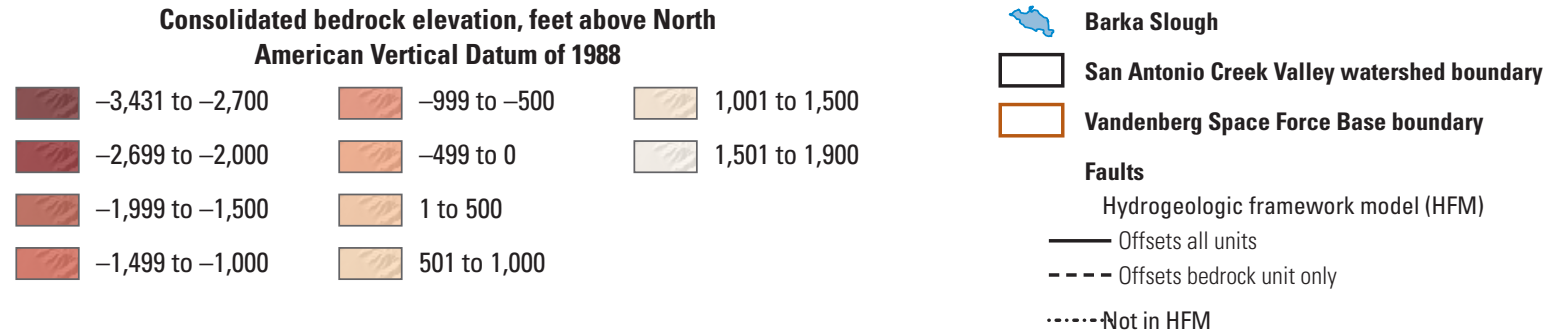

Figure 21. Elevation of the consolidated bedrock from the three-dimensional hydrogeologic framework model for the San Antonio Creek Valley watershed, Santa Barbara County, California (Ely and others, 2022).

each fault block, and offsets across each fault were maintained during the gridding process by utilizing data point elevations on either side of the fault surface for each hydrogeologic unit. Each of the fault blocks were modeled independently and then combined to form a single model. The resulting EarthVision horizon grids were exported to Esri ArcGIS version 10.7.1 geographic information systems software and were manually adjusted to enforce a minimum thickness of about $10 \mathrm{ft}$ for each hydrogeologic unit and to ensure that the grid was consistent with basic geologic principles and the geologic understanding of the SACVW.

Maps showing the extent, elevation, and thickness of the hydrogeologic units in the HFM are shown in figures 21 and 22. Figure 21 shows the elevation of the top of the consolidated bedrock unit. Consolidated bedrock is present across the SACVW and defines the east-plunging synclinal structure of the basin. Surface outcrops of this unit in the Purisima and Solomon Hills are at elevations of more than
1,600 feet above the North American Vertical Datum of 1988 (NAVD 88), but in the center of the basin, the unit surface is as deep as about 3,200 feet below NAVD 88. Figure 22 shows map view images of the extent and thickness of the basin-fill hydrogeologic units. Careaga Sandstone is present across most of the SACVW and ranges from about 10 feet thick in the Purisima and Casmalia Hills to upward of 3,000 feet thick in the center of the basin (fig. 22A). The lower, middle, and upper Paso Robles Formation occupy successively smaller areas in the synclinal axis of the basin (figs. $22 B-D$ ). Channel alluvium is present along San Antonio Creek and other active stream channels in the SACVW (fig. 22E). Channel alluvium was difficult to distinguish from underlying units; therefore, average thicknesses were assigned to the channel alluvium based on the work of Muir (1964): $82 \mathrm{ft}$ on the valley floor along San Antonio Creek, $49 \mathrm{ft}$ in Harris Canyon and along San Antonio Creek west of Barka Slough, and $16 \mathrm{ft}$ in all tributary streams. 
$\boldsymbol{A}$

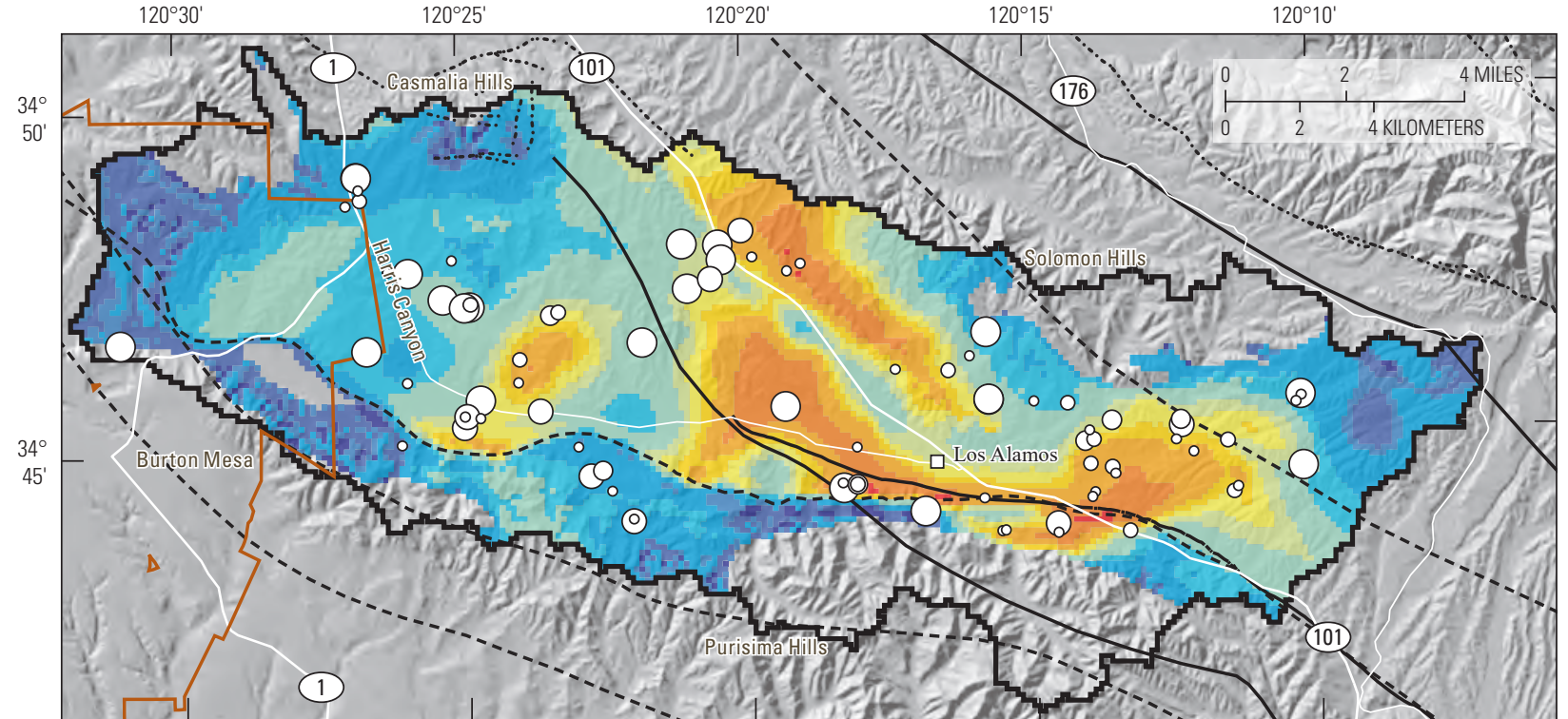

Base from U.S. Geological Survey and other Federal and State digital data, various scales;

Universal Transverse Mercator projection, zone 10; North American Datum of 1983

B

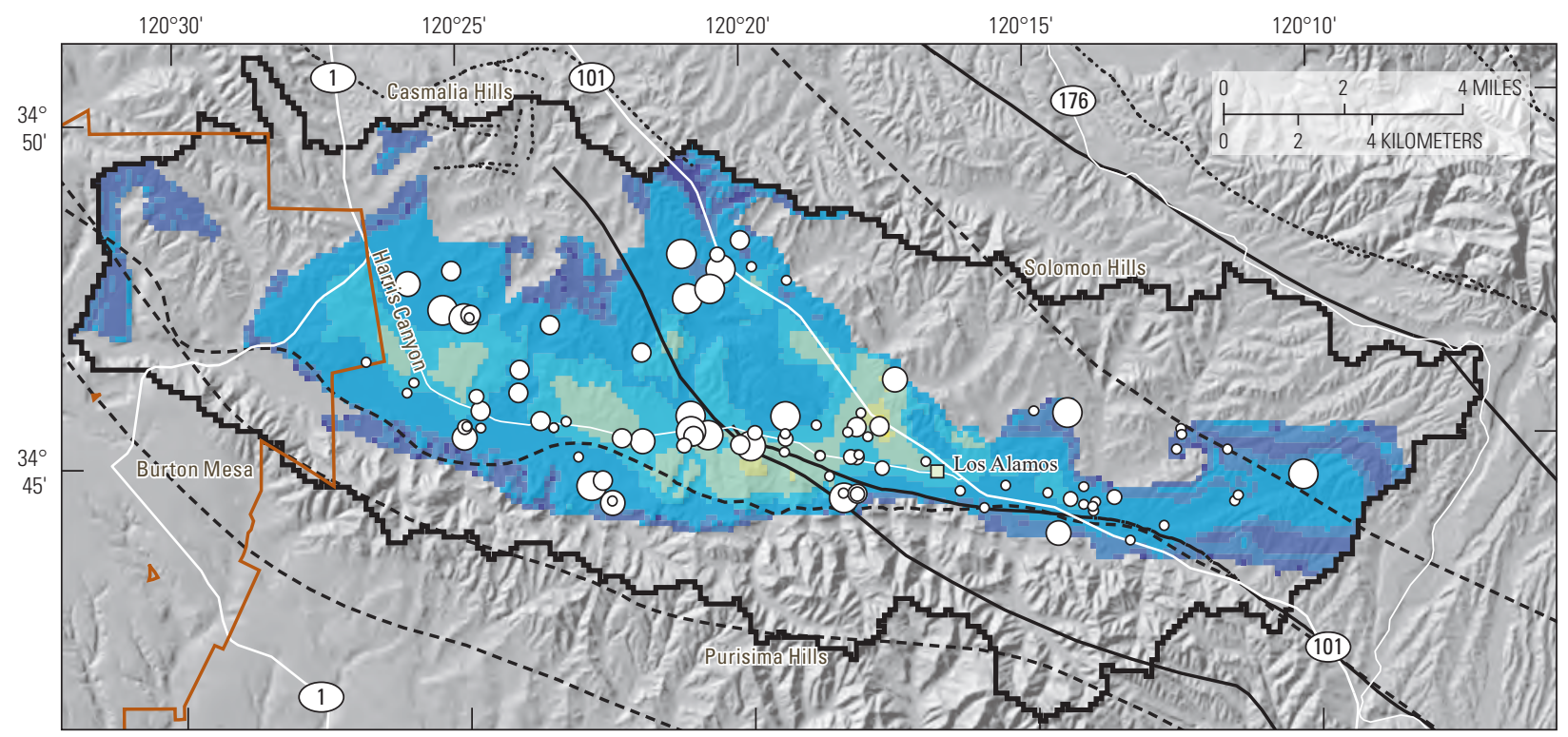

Base from U.S. Geological Survey and other Federal and State digital data, various scales:

Universal Transverse Mercator projection, zone 10; North American Datum of 1983

EXPLANATION
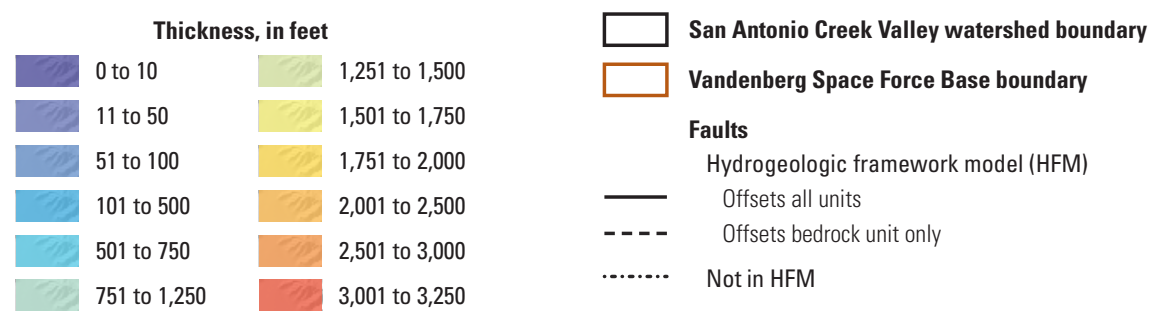
Percent coarse
[>, greater than]
- 0 to 20
O $>20$ to 40
O >40 to 60
$\bigcirc>40$ to 80
$>>80$ to 100

Figure 22. Extent and thickness of basin-fill hydrogeologic units from the three-dimensional hydrogeologic framework model for the San Antonio Creek Valley watershed, Santa Barbara County, California (Ely and others, 2022): $A$, Careaga Sandstone; $B$, lower Paso Robles Formation; $C$, middle Paso Robles Formation; $D$, upper Paso Robles Formation; and $E$, channel alluvium. Also shown are the estimated percentage of coarse-grained materials for boreholes that penetrate each unit. 
C

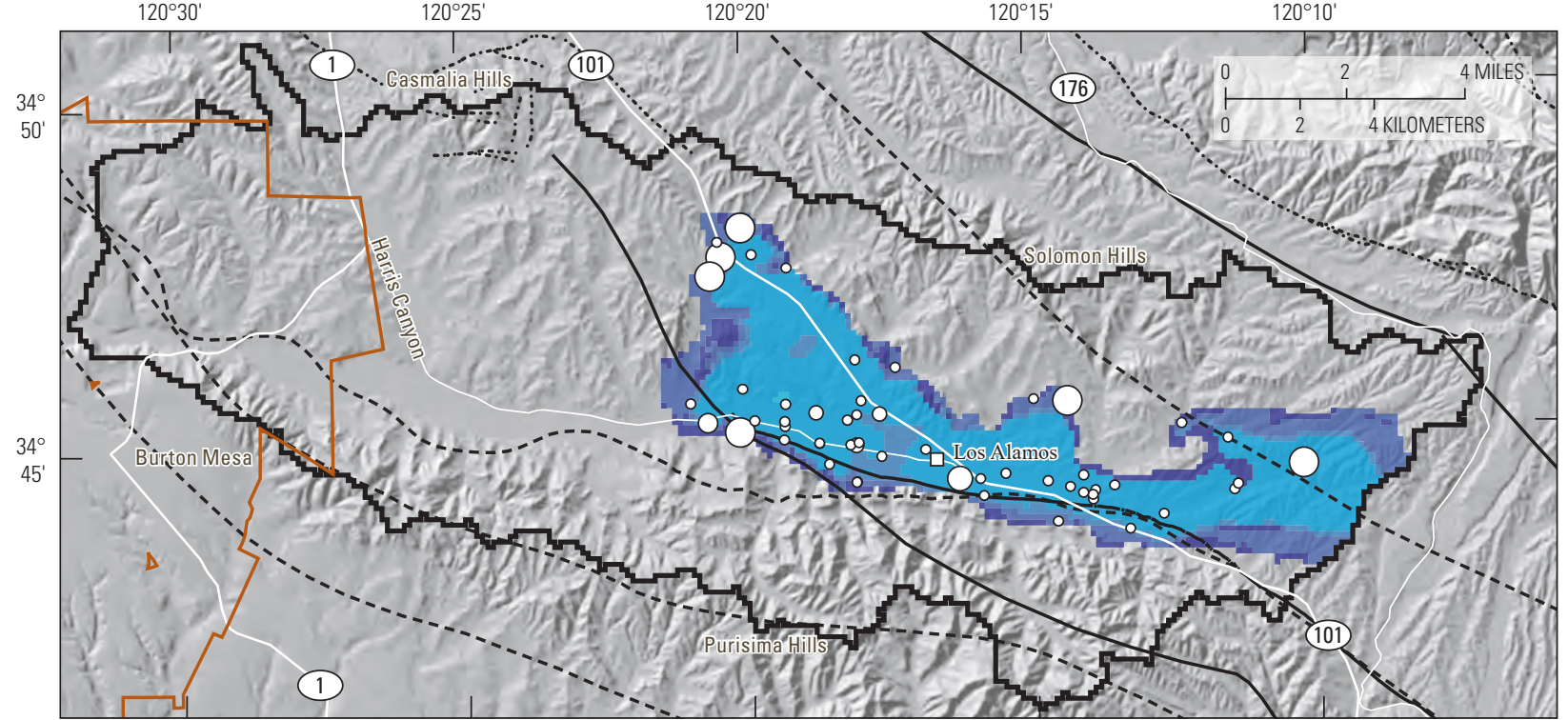

Base from U.S. Geological Survey and other Federal and State digital data, various scales; Universal Transverse Mercator projection, zone 10; North American Datum of 1983

D

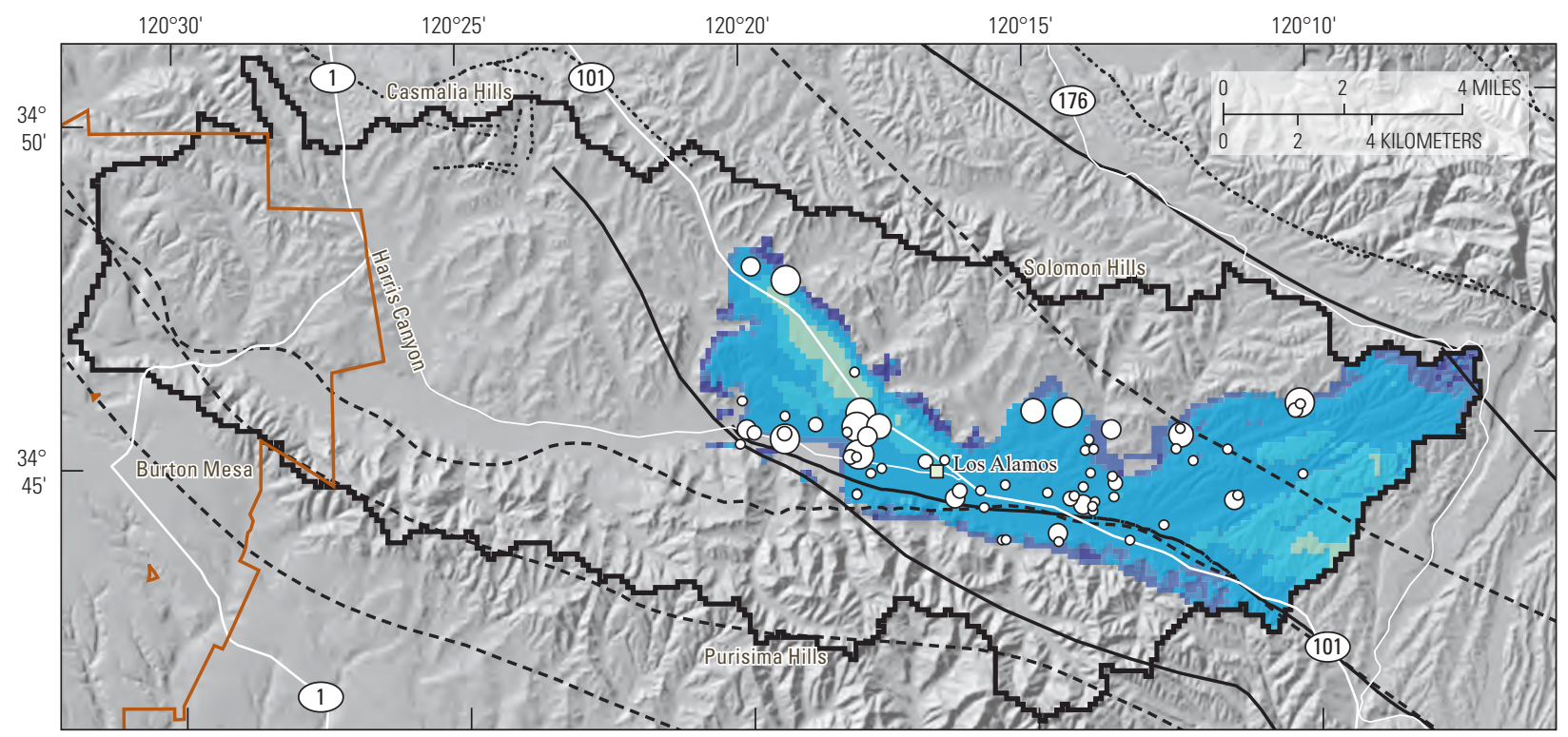

Base from U.S. Geological Survey and other Federal and State digital data, various scales

Universal Transverse Mercator projection, zone 10; North American Datum of 1983

\section{EXPLANATION}
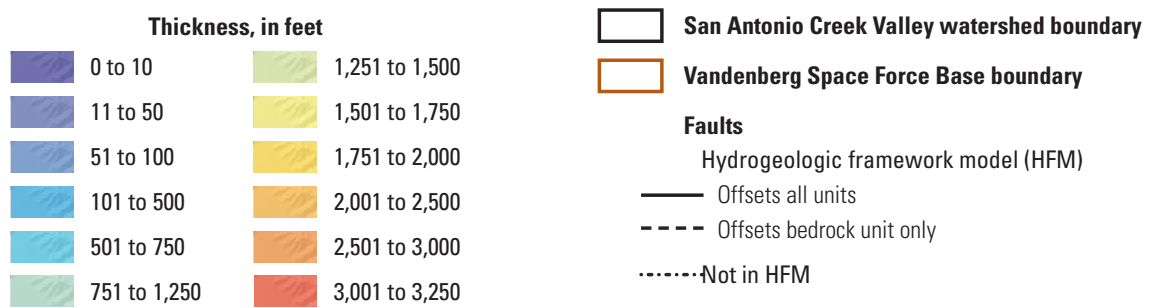

Percent coarse

$[>$, greater than $]$

- 0 to 20

O $>20$ to 40

$0>40$ to 60

$>40$ to 80

........ Not in HFM

$>80$ to 100

Figure 22.-Continued 
$\boldsymbol{E}$

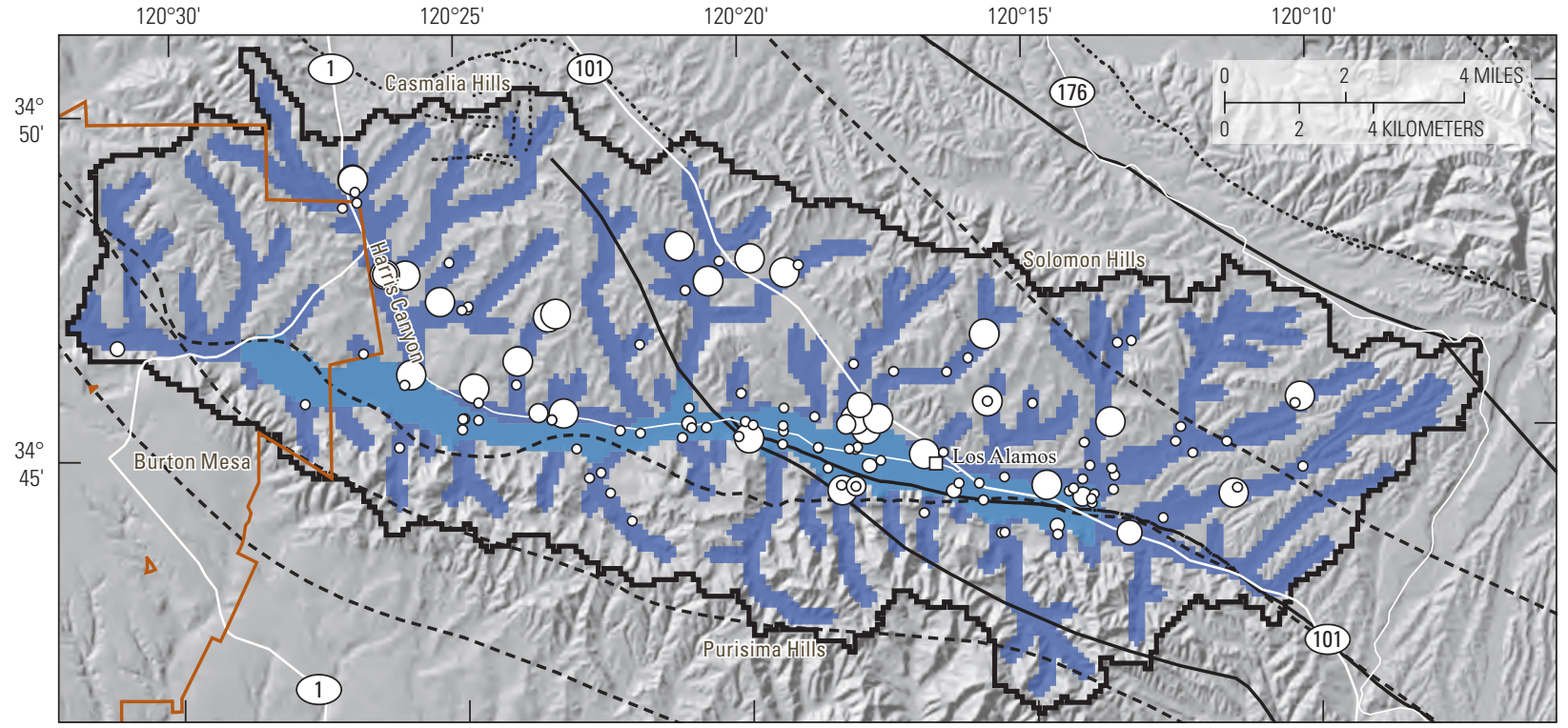

Base from U.S. Geological Survey and other Federal and State digital data, various scales; Universal Transverse Mercator projection, zone 10; North American Datum of 1983

\section{EXPLANATION}

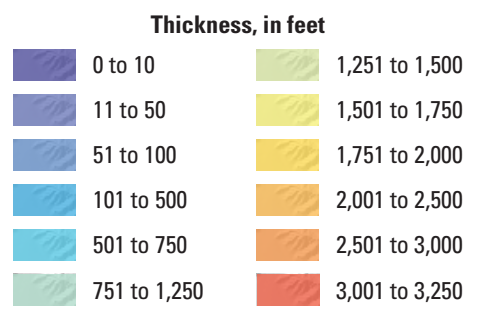
Percent coarse
$[>$, greater than]
- 0 to 20
O $>20$ to 40
O $>40$ to 60
$\bigcirc>40$ to 80
$>>80$ to 100

Figure 22.-Continued

An egg-crate diagram of the HFM is shown in perspective view in figure 23 and two vertical cross-section panels through the HFM are shown in figure 24. The perspective view of the HFM shows the upper surface of the consolidated bedrock horizon as a solid-block and the basin-fill hydrogeologic units as a series of east-west and north-south vertical profiles. The Careaga Sandstone is present across the SACVW and fills most of the volume above consolidated bedrock. The lower member of the Paso Robles Formation is the second most-voluminous unit in the HFM: the unit varies in thickness, follows the structure of the underlying Careaga Sandstone and consolidated bedrock, and thins against the underlying Careaga Sandstone east of well SALA. The middle fine-grained member of the Paso Robles Formation is thin and barely visible at the scale presented in figure 23. The upper member of the Paso Robles Formation fills the uppermost part of the model volume and is the second most voluminous unit in the southeastern part of the HFM. Channel alluvium is also not easily visible at the scale presented in figure 23.

Vertical sections through the HFM (fig. 24) illustrate the thickness, extent, and configuration of hydrogeologic units in the SACVW. The east-west oriented cross-section (A-A'; fig. 24A) shows the along-axis structure of the SACVW; at the west (left) end of the cross-section, consolidated bedrock is exposed at land surface and overlain by a thin layer of Careaga Sandstone and channel alluvium. Barka Slough is located above these uplifted units, west of the lower member of the Paso Robles Formation. The hydrogeologic units dip to the east (right), following the eastward plunge of the Los Alamos syncline (fig. 16). The total thickness of the Paso Robles Formation increases from west to east, until just east of well-site SACC; here, the synclinal plunge is less prominent, and the hydrogeologic units rise to the east. The south-north oriented cross-section (B-B'; fig. 24B) shows the synclinal structure of the SACVW, with all units dipping inward toward the axis of the basin. The syncline is asymmetric, with the consolidated bedrock and Careaga Sandstone dipping more shallowly on the north (right) side of the basin than the south (left) side. The overlying units thin and disappear at the margins of the basin and differ in their dip patterns from the underlying consolidated bedrock and Careaga Sandstone, implying stratigraphic onlap or angular unconformity between the hydrogeologic units. 


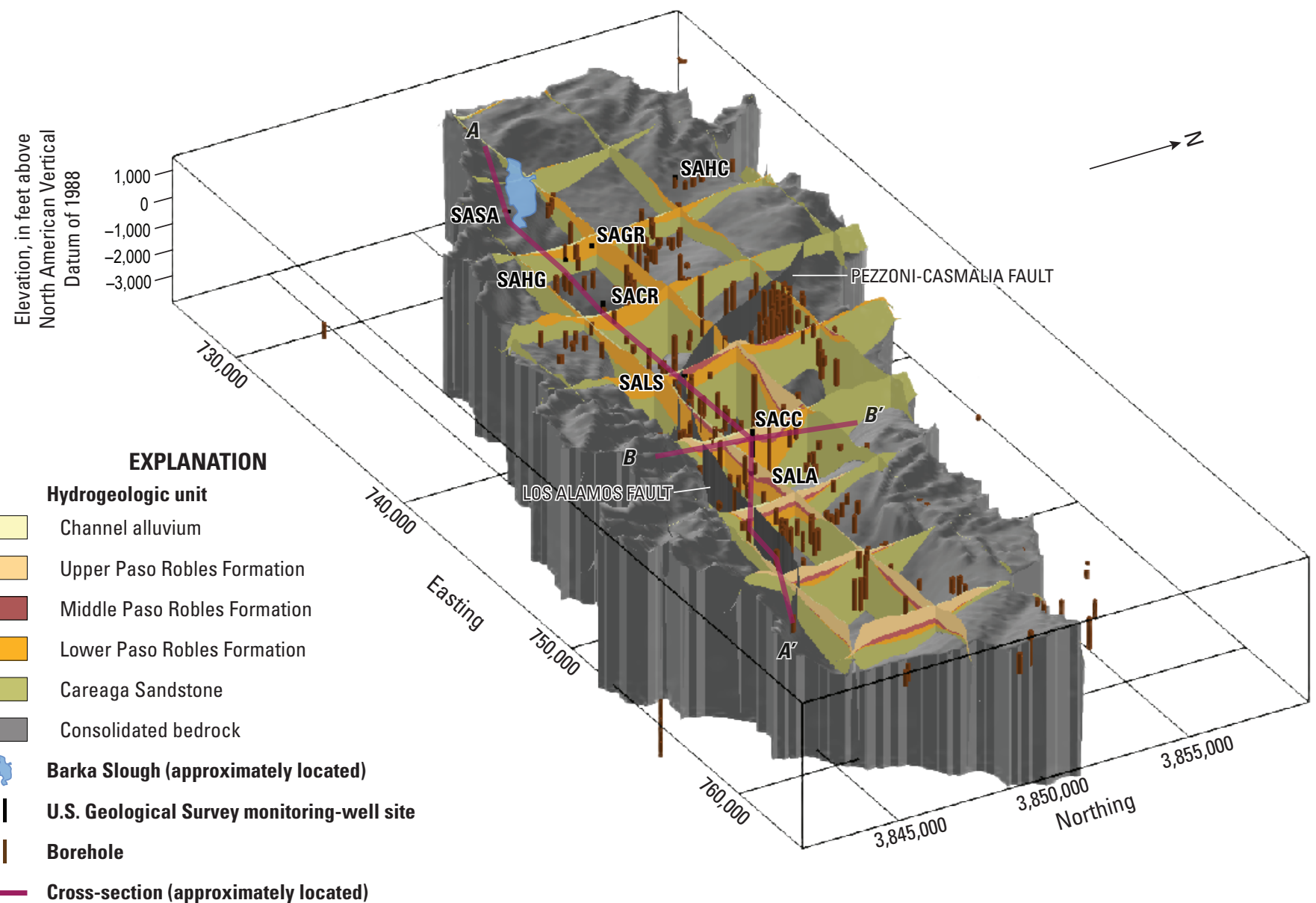

Figure 23. Egg-crate diagram of the three-dimensional hydrogeologic framework model for San Antonio Creek Valley watershed, Santa Barbara County, California (Ely and others, 2022). U.S. Geological Survey monitoring-well sites and other boreholes are shown "hanging" from land surface. Vertical exaggeration is $3 x$.

The thickness of basin-fill hydrogeologic units in the SACVW ranges from 0 to $650 \mathrm{ft}$ at the western and eastern margins of the basin, to more than 3,200 ft east of the Pezzoni-Casmalia fault in the center of the basin (fig. 24). The Careaga Sandstone is thicker than the combined thickness of the lower, middle, and upper members of the Paso Robles Formation, which are thickest in the middle part of the SACVW, just east of well SACC; the synclinal plunge is less prominent, and the hydrogeologic units rise to the east (fig. 24A). In the northern part of the SACVW, the hydrogeologic units dip gently southward toward the fold axis. The unit horizons in the northern part of the SACVW also indicate the presence of at least one additional anticline-syncline fold structure, north of well SACC, consistent with the surface geologic map. In the southern part of the SACVW, hydrogeologic units dip steeply southward toward the fold axis (fig. 24B).

\section{Framework Model Summary and Limitations}

The HFM is a hydrogeologic model that was developed to synthesize geologic structures and hydrologic information, hydrogeologic conditions, and the relative hydrologic importance of hydrogeologic units in the SACVW for use in a numerical hydrologic model (Woolfenden and others, 2022). The consolidated bedrock unit (a combination of primarily Tertiary sedimentary rocks) is assumed to be hydrologically homogeneous and likely provides limited, if any, contribution to the groundwater flow system. The Careaga Sandstone is treated as a geologic and hydrogeologic unit in the HFM and is assumed to be a hydrologically homogeneous, semi-consolidated, fine-grained sandstone that may contribute to groundwater availability in the SACVW. 

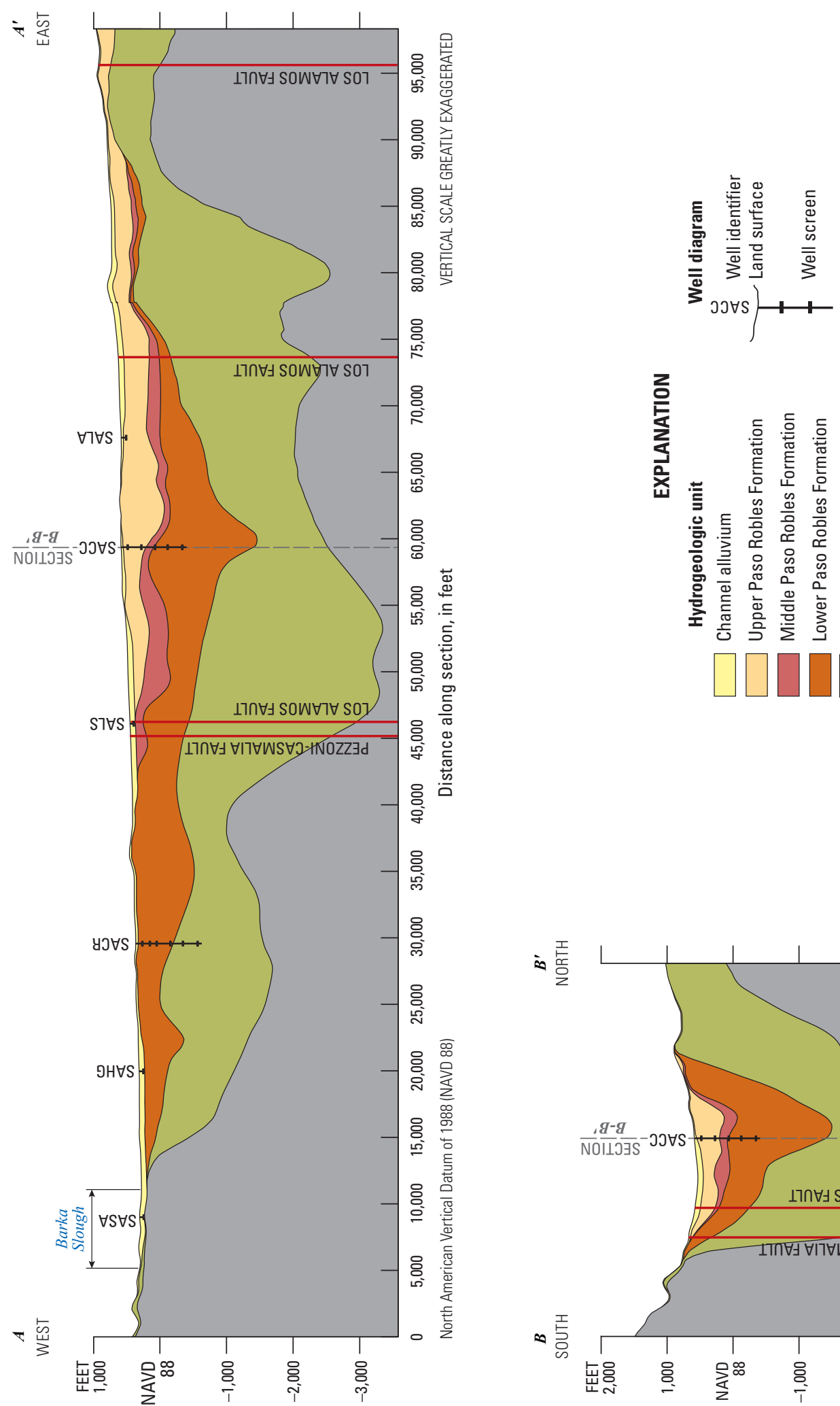

昙
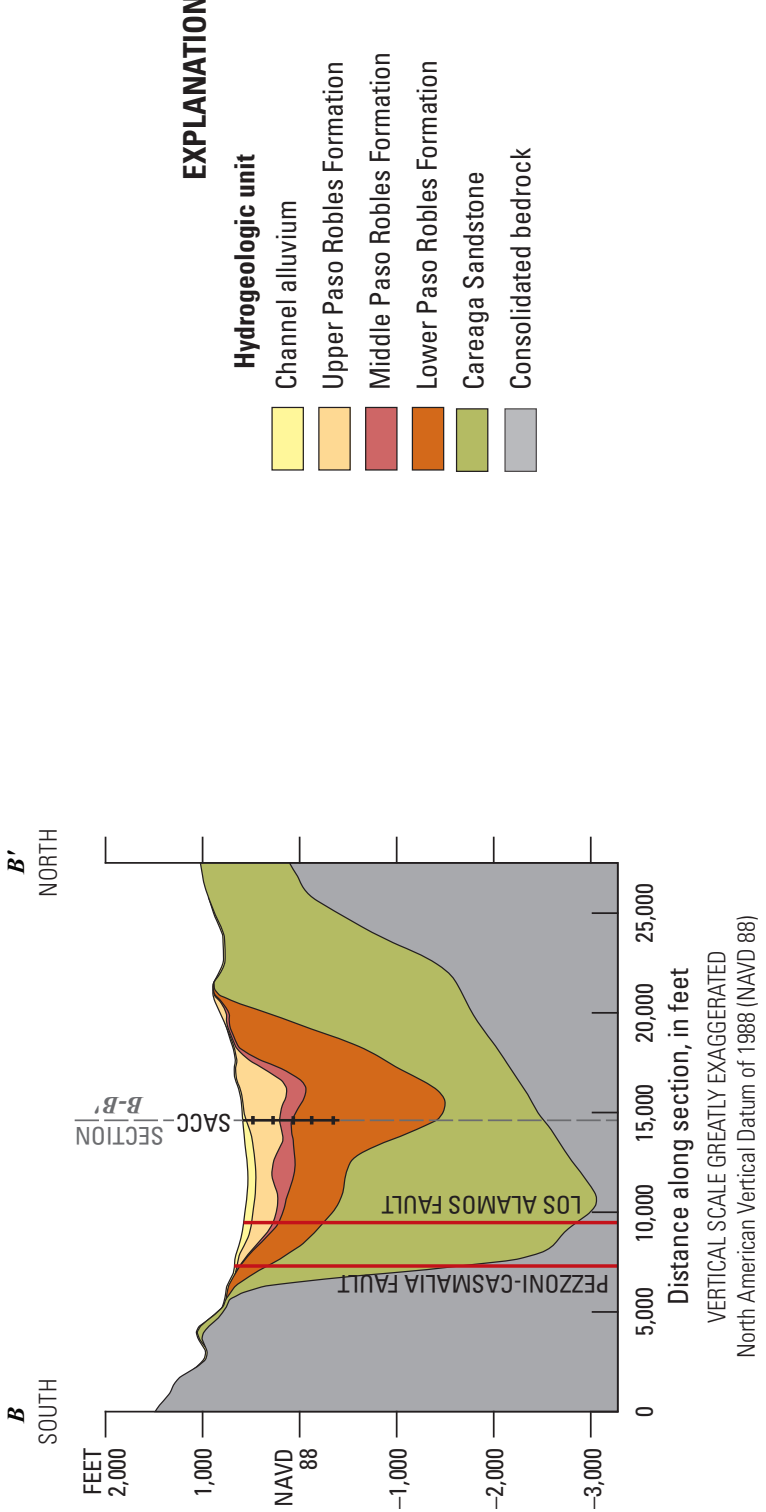

$\infty$ 
Subsurface lithologic data and hydrologic data were combined to demonstrate that the Paso Robles Formation is more lithologically and hydrologically heterogeneous in the SACVW than has been shown on geologic maps of the region (Woodring and Bramlette, 1950; Dibblee and Ehrenspeck, 1988, 1989, 1993a, b; Dibblee and others, 1994a, b). Therefore, the Paso Robles Formation was divided into upper, middle, and lower hydrogeologic units. The coarser-grained lower and upper units of the Paso Robles Formation likely provide more groundwater storage within the formation than the informal, fine-grained middle unit. The predominantly fine-grained middle unit of the Paso Robles Formation functions as a semi-confining to confining unit depending on its subsurface continuity within the basin. A similar fine-grained lithostratigraphic interval within the Paso Robles Formation has been identified in the Los Osos Valley groundwater basin (not shown) about $60 \mathrm{mi}$ north of the SACVW in San Luis Obispo County, California (Cleath-Harris Geologists, 2018); however, without age control in both basins, it is unclear whether these stratigraphic sequences are age-equivalent and represent a single event. Available borehole data indicate that the SACVW may have additional local confining layers in the heterogeneous lower and upper units of the Paso Robles Formation (fig. 20; Ely and others, 2022).

Faults in the HFM are known or inferred to be present from geologic and geophysical evidence (see "Faults" section), but their potential influence on groundwater flow in the SACVW is poorly understood. Faults can inhibit groundwater flow in permeable sediments through the presence of fine-grained gouge material, chemical cementation of sediments, and the juxtaposition of transmissive layers across faults. The Pezzoni-Casmalia and Los Alamos faults transect the SACVW and are the faults most likely to influence groundwater flow in the basin because they are mapped as transecting the basin-fill hydrogeologic units (fig. 17).

The conceptual hydrogeology of the SACVW developed based on previously published reports and analysis of hydrogeologic data was central to the construction of the HFM. The conceptual model (which includes the conceptual section in fig. 20) provided an interpretive framework on which to build the digital HFM and guided model development so that the model did not simply rely on extrapolation of input data. The HFM is partly deterministic because the model output is defined by the input data. The HFM is also partly conceptual because the initial horizons generated by the EarthVision geologic modeling software were based on interpolation of hydrogeologic information. These horizons generally represented the input data and provided reasonable geologic representations of each hydrogeologic unit. The SACVW is a relatively narrow basin; therefore, interpolation distances were short and input data were sufficient to constrain horizon gridding. Adjustments to unit extents were required where units thinned out and disappeared, beyond, or fell short of their expected terminations. Unit thicknesses were manually adjusted to be at least 10 feet thick, or 16 feet in the case of the channel alluvium. The resulting HFM provides a balance between closely matching available data and following the conceptual hydrogeology developed for the basin.

\section{Definition of the Aquifer System}

The aquifer system in the SACVW consists mainly of semi-consolidated, basin-fill sedimentary materials underlain by consolidated bedrock (figs. 17, 24). Most water wells are perforated in the lower and upper units of the Paso Robles Formation and the Careaga Sandstone (see "Long-Term Trends in Groundwater Levels" section), indicating that these units are the main water-bearing units in the SACVW. The hydrogeologic units generally are considered unconfined where present at land surface and confined where overlain by other units. Channel alluvium is the only unit that is considered unconfined across its entire extent. The upper Paso Robles Formation is considered unconfined, and the middle Paso Robles Formation is considered confined. The lower Paso Robles Formation is considered unconfined in the western part of the SACVW and confined in the eastern part of the SACVW. Careaga Sandstone generally is considered unconfined in the upland areas and confined in the valley areas. Consolidated bedrock is considered confined except where it crops out near the boundary of the SACVW. Localized artesian conditions have been observed where the middle Paso Robles Formation overlies the lower Paso Robles Formation, and in the northern part of the valley where the Careaga Sandstone is at shallow depths beneath the Paso Robles Formation.

The water-bearing properties of each hydrogeologic unit vary because of geologic heterogeneity, depth below land surface, and other factors related to the depositional history pf the hydrogeologic units; estimations of these properties can help determine how aquifers may be affected by changes in recharge, pumping, and other stresses. The available well data provided sufficient information for a semi-quantitative description of the aquifer characteristics in the SACVW to a depth of about 1,000 ft (U.S. Geological Survey, 2021; Ely and others, 2022). Data to define the physical characteristics or hydraulic properties of the hydrogeologic units below depths commonly drilled for water wells are sparse. Most of the water wells drilled in the SACVW through 2016 are 1,000 ft or less in depth; only 22 water wells compiled for the HFM were drilled to depths greater than $1,000 \mathrm{ft}$ (U.S. Geological Survey, 2021; Ely and others, 2022). The aquifer properties of the hydrogeologic units are described in the following section. 


\section{Aquifer Properties}

Aquifer properties (transmissivity, horizontal and vertical hydraulic conductivity, specific yield, and specific capacity) and textural analysis of grain size for the hydrogeologic units in the SACVW were reported in previous studies and estimated from aquifer slug tests performed at USGS monitoring-well sites, and from borehole lithology data compiled for the HFM (sources of these data are discussed below). Aquifer property and textural data can form the geologic basis for estimating the hydraulic properties within a numerical hydrologic-flow model (Burow and others, 2004; Faunt and others, 2010). A summary of the aquifer property and textural grain-size information collected and compiled for this study are presented below and discussed in more detail for each of the hydrogeologic units.

Previous studies of the SACVW reported estimates of transmissivity, but reported values are often for the basin-fill materials in general and not specific to a particular aquifer unit. Hutchinson (1980) reported transmissivity values ranging from 2,600 to 34,000 square feet per day ( $\left.\mathrm{ft}^{2} / \mathrm{d}\right)$, but none of the wells used by Hutchinson (1980) to test the aquifer penetrated more than half the estimated aquifer thickness. The highest transmissivity values reported by Hutchinson (1980) were near the perimeter of the SACVW, while the lowest values were reported along the valley floor. In contrast, Martin (1985) reported calibrated transmissivity values from their groundwater model ranging from less than $100 \mathrm{ft}^{2} / \mathrm{d}$ along the perimeter of the SACVW, to more than $20,000 \mathrm{ft}^{2} / \mathrm{d}$ along the valley floor. Tetra Tech, Inc. (2013) reported horizontal hydraulic conductivity values from a calibrated groundwater model ranging from 0.08 to 400 feet per day (ft/d) and vertical hydraulic conductivity values ranging from 0.005 to $0.1 \mathrm{ft} / \mathrm{d}$. The average specific capacity of wells in the SACVW was reported to be about 11 gallons per minute per foot $(\mathrm{gal} / \mathrm{min} / \mathrm{ft})$ of drawdown (Muir, 1964).

Aquifer slug tests were completed at each of the USGS single- and multiple-depth, monitoring-well sites, and at monitoring well 8N/34W-21A1 (fig. 17; table 7; Ely and others, 2022), to estimate the hydraulic conductivity of the hydrogeologic units that comprise the aquifer system. Groundwater levels for each well were measured prior to aquifer slug testing and were monitored using pressure transducers during the tests. A physical slug was used for the slug test if the initial measured groundwater level was within about $7 \mathrm{ft}$ of the perforation interval, otherwise an air slug was used. Air slugs were avoided when the groundwater level was near the top of the perforation interval to avoid displacing the water level to below the top of the interval during testing (Arnold, 2015). Pressure transducers were installed at depths ranging from 7 to $15 \mathrm{ft}$ below the initial pre-test groundwater level, and the slug was lowered to approximately $5 \mathrm{ft}$ above the initial groundwater level. Sufficient time, about 15 to 20 minutes for most wells, was allowed for groundwater levels in the well to recover before completing another slug test.
Multiple slug tests were performed at each well to check for consistency between the different tests and provide enough data to statistically evaluate the test results.

Evaluation tools developed by Halford and Kuniansky (2002) and Butler and Garnett (2000) were used to help evaluate the slug-test data and estimate hydraulic conductivity (table 7; Ely and others, 2022). The following assumptions were made for data evaluation using both methods: the volume of water injected into or discharged from the well occurs instantaneously at time $(\mathbf{t})=0$, the well diameter is finite, and the well fully penetrates the aquifer. The aquifers were assumed to be confined, homogeneous, isotropic, and uniform in thickness, the flow of groundwater within the aquifer was assumed to be horizontal and radially symmetric, and the response within the aquifer was assumed to be influenced across the entire screened interval. Relatively small changes in hydraulic head were observed in all wells; therefore, early-time data (about $2-10$ seconds) were removed from the datasets used in the analysis.

The single-depth, monitoring-well sites and shallowest wells of the multiple-depth, monitoring-well sites (SACC5 and SACR5), and monitoring well 8N/34W-21A1 were assumed to be in unconfined aquifers; therefore, the Bouwer-Rice method of analysis (Bouwer and Rice, 1976) was used to evaluate the slug test data (table 7; fig. 17). For these wells, the results from the Bouwer-Rice method were checked against or compared to the Cooper-Greene method of analysis (Cooper and others, 1967; Shapiro and Greene, 1995; Greene and Shapiro, 1998), unless the water level was within the screened interval, and the KGS_High-K analysis method (Butler and others, 2003) for consistency in hydraulic conductivity value, curve match, and root mean square error. The deep wells of the multiple-depth, monitoring-well sites (SACC1 to SACC4 and SACR1 to SACR4; fig. 17; table 7) were assumed to be in confined aquifers, and either the Cooper-Greene or KGS_High-K method was used for analysis. A summary of the analytical results for each well is presented in table 7 , shown in figure $25 \mathrm{~A}$, and discussed for each hydrogeologic unit below.

An analysis of the textural variability of lithology and grain size was performed for the basin-fill hydrogeologic units using borehole data (figs. 22, 26; Ely and others, 2022). The primary variable used was sediment grain size, tabulated as percentage of coarse-grained texture (Phillips and Belitz, 1991; Burow and others, 2004; Faunt and others, 2010). For each well in the study area, each downhole lithologic interval was classified in a binary fashion as either "coarse-grained" or "fine-grained" based on the well driller's description (Ely and others, 2022). In this study, coarse-grained intervals were those dominated by gravel- and sand-size clasts with little to no clay matrix; all other lithology classes were considered fine grained. Units that had a considerable fraction of large clasts were classified as fine grained if the clasts tended to be suspended in a fine-grained matrix. Textural variability in the basin-fill units is ultimately a function of the sedimentary facies, environment of deposition, and depositional history of the basin. 
음

胥

త్ర

응 $\frac{\pi}{5}$

我

흘

สิธ

羟

党

두달

更

产

里

幽

畓

高

言

등

.

究

蒿

灾

至

ฮั

당

㦴

क

С

क्

.

密

齐

离

긍

을

䯧

旁

3 乙

竞

$\overline{\bar{D}}$

$>$ 음

高高竞
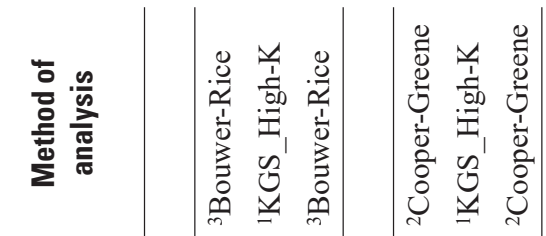

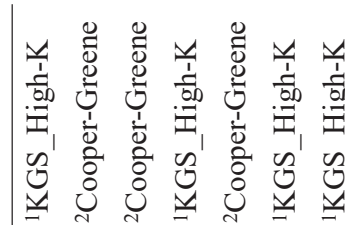

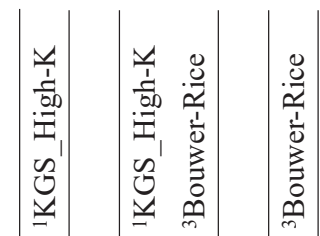

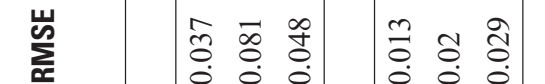

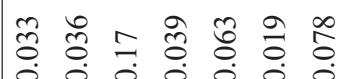

范

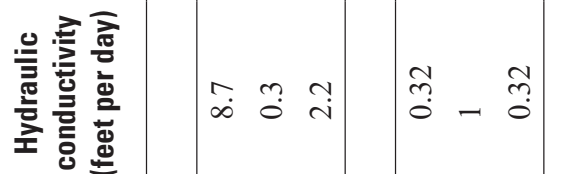

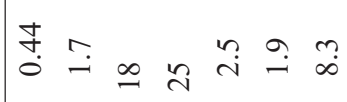

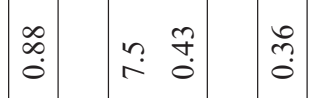

$=$ 离

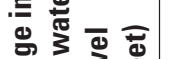

蛋总

$\begin{array}{ccc}0 & = & 0 \\ 0 & \overline{1} & 0 \\ 0 & 1 & 0\end{array}$

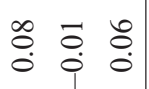

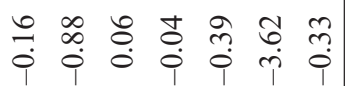

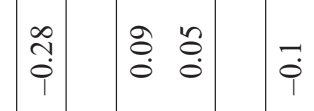

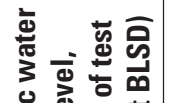

ㅊ.

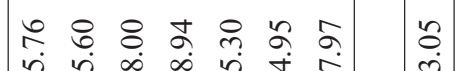

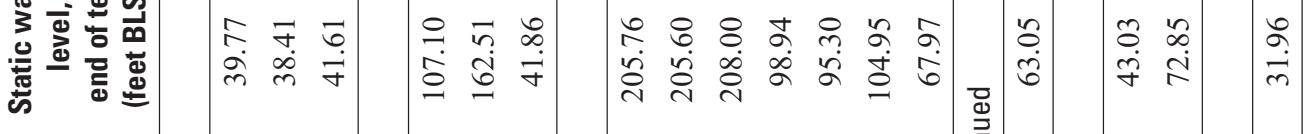

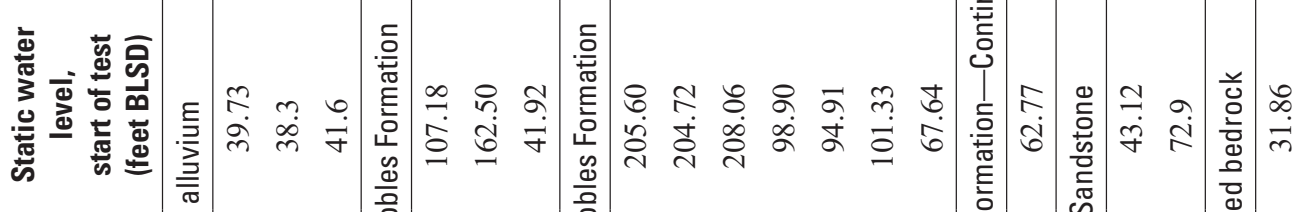

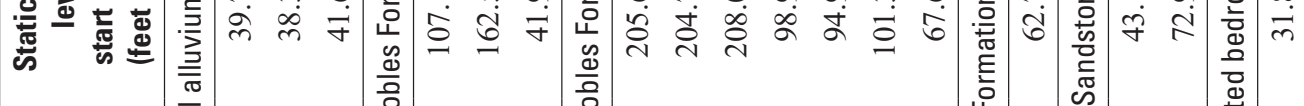

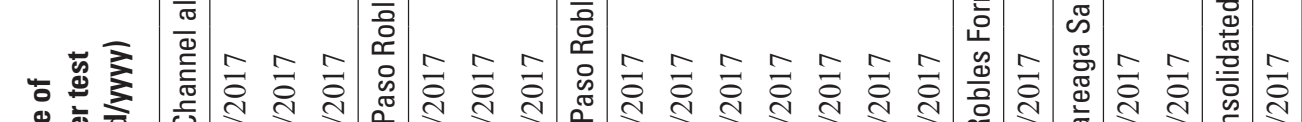

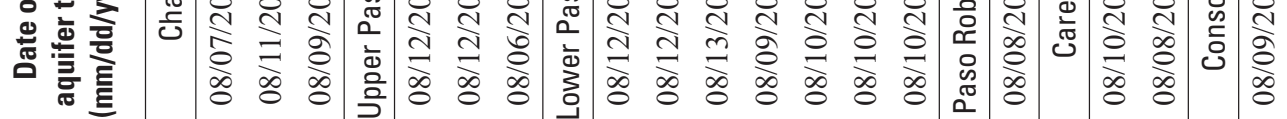

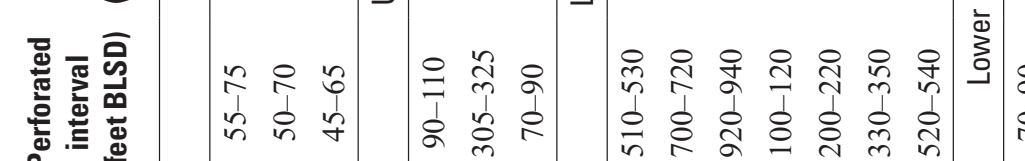

: \&

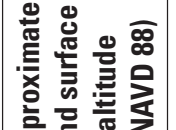

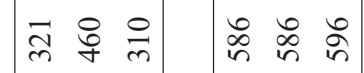

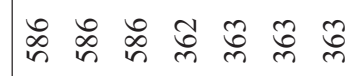

㞔

흘들

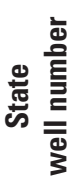

ت⿸\zh14𠃋

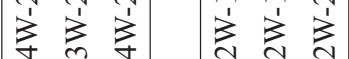

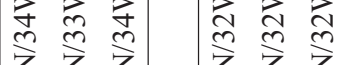

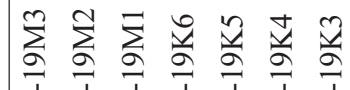

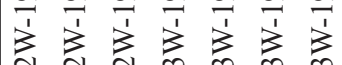

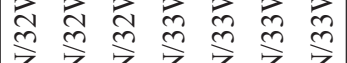

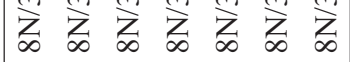

$\infty$

ż

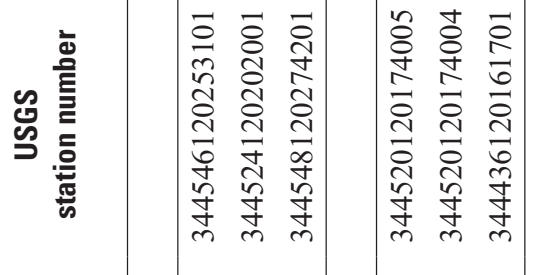

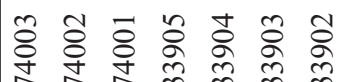

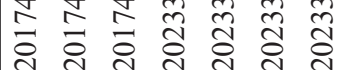

ते

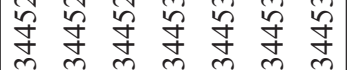

वे

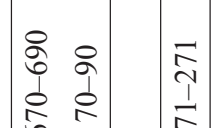

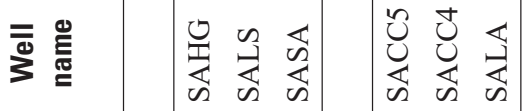

记

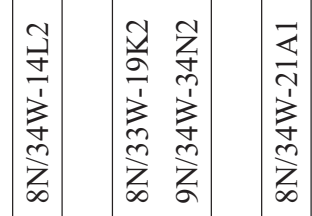

旁

啇

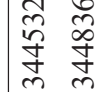

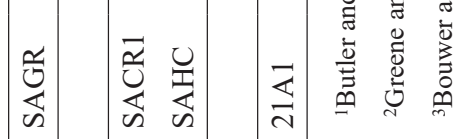


$\boldsymbol{A}$

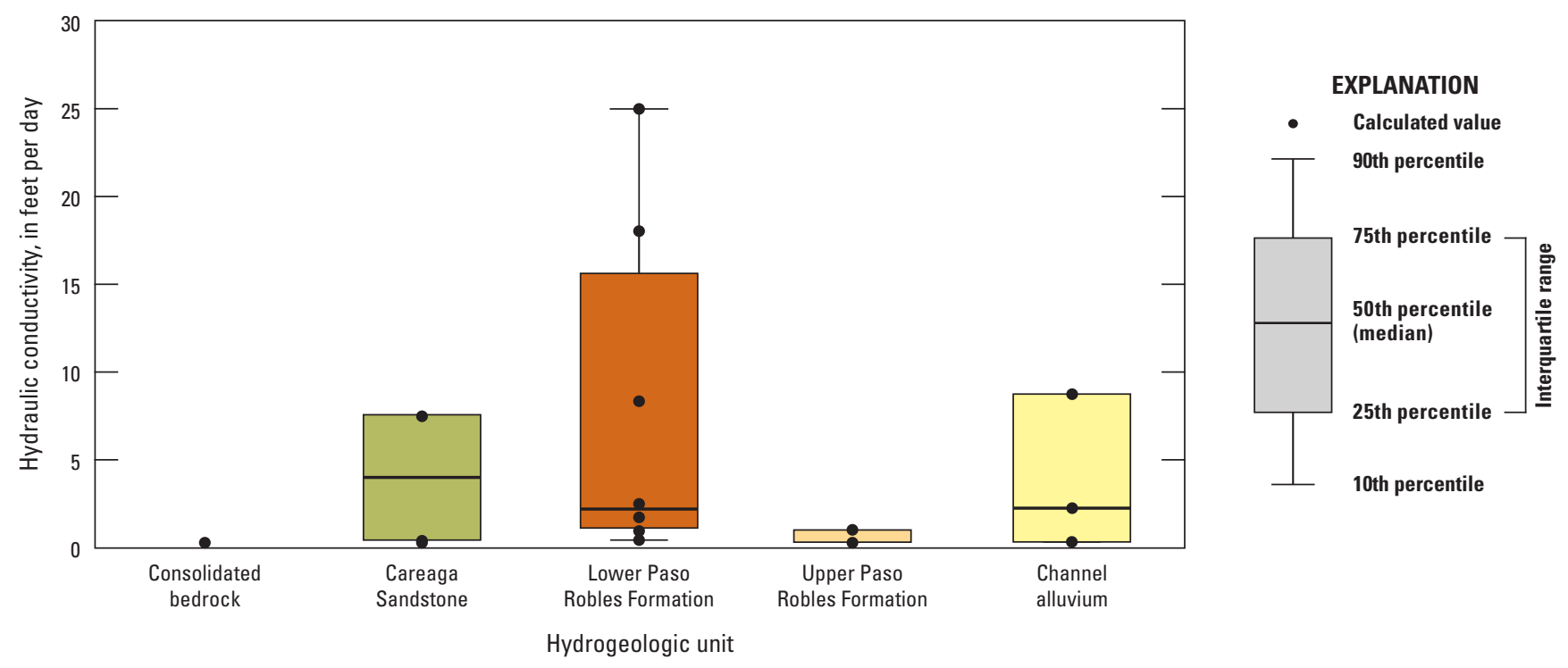

B

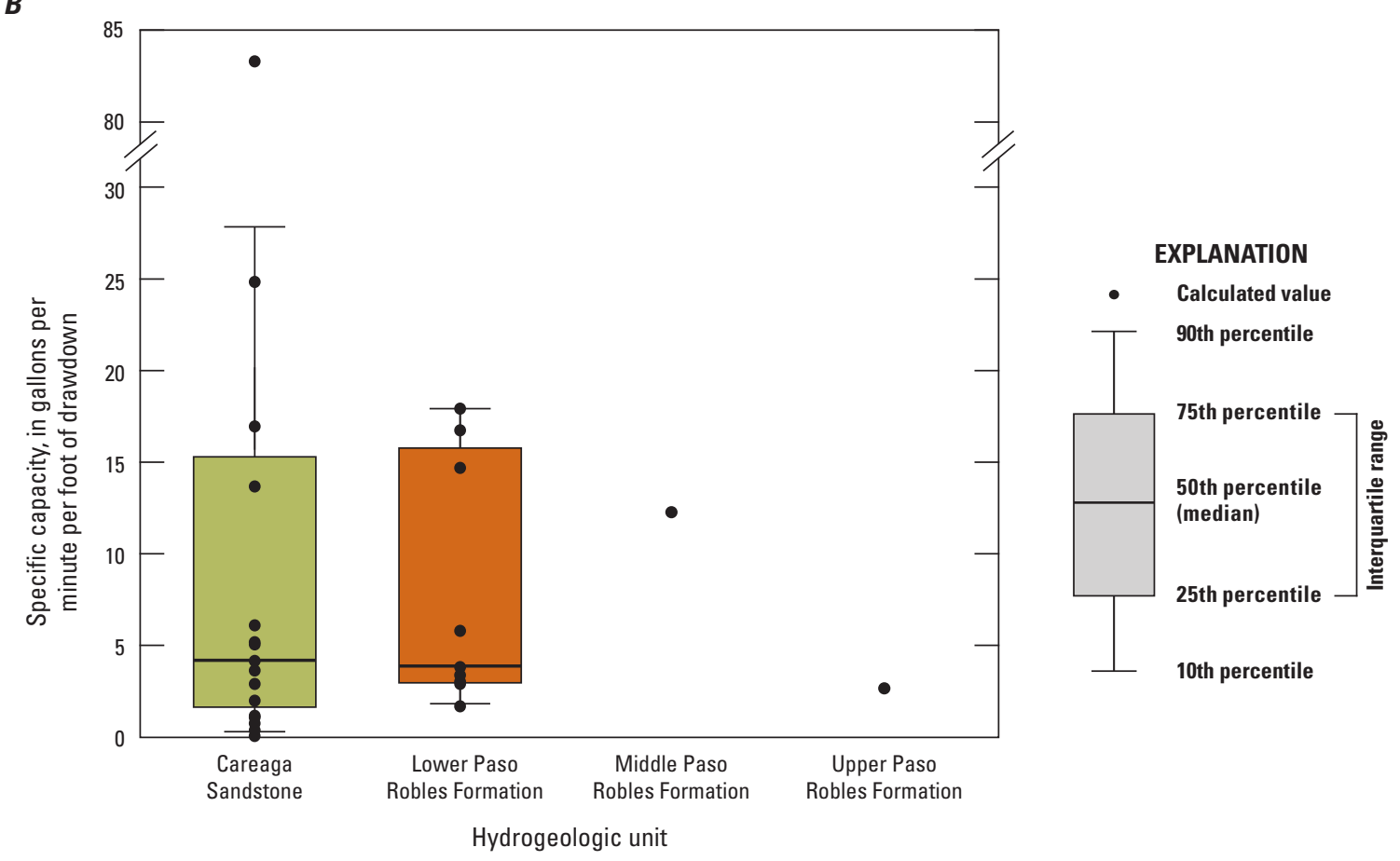

Figure 25. Measured aquifer properties of hydrogeologic units in the San Antonio Creek Valley watershed, Santa Barbara County, California. $A$, hydraulic conductivity (Ely and others, 2022, table 7), and $B$, specific capacity (table 1.3).

Textural data were compiled by digitally intersecting the downhole lithologic interval data (in 16-ft intervals) in each borehole with the elevation of the top of each basin-fill hydrogeologic unit, thereby assigning specific lithologic intervals to a hydrogeologic unit at each borehole. The percentage of coarse-grained material for a borehole within a given hydrogeologic unit was calculated as the aggregate thickness of coarse-grained intervals penetrated by the borehole, divided by the total thickness of the unit in that borehole (fig. 22). The frequency of percent coarse values for each hydrogeologic unit was then normalized by the total thickness of all boreholes that penetrated that unit and plotted as frequency distributions (fig. 26).

Specific capacity data were calculated for 28 water wells with reported aquifer pump test data (fig. 25B; table 1.3). Calculated specific capacity results were assigned to hydrogeologic units for which at least 60 percent of the reported perforation interval intersected a given unit. A value of 60 percent of the perforation interval intersection was chosen to provide a reasonable distribution of specific capacity estimates for each hydrogeologic unit. 
$\boldsymbol{A}$

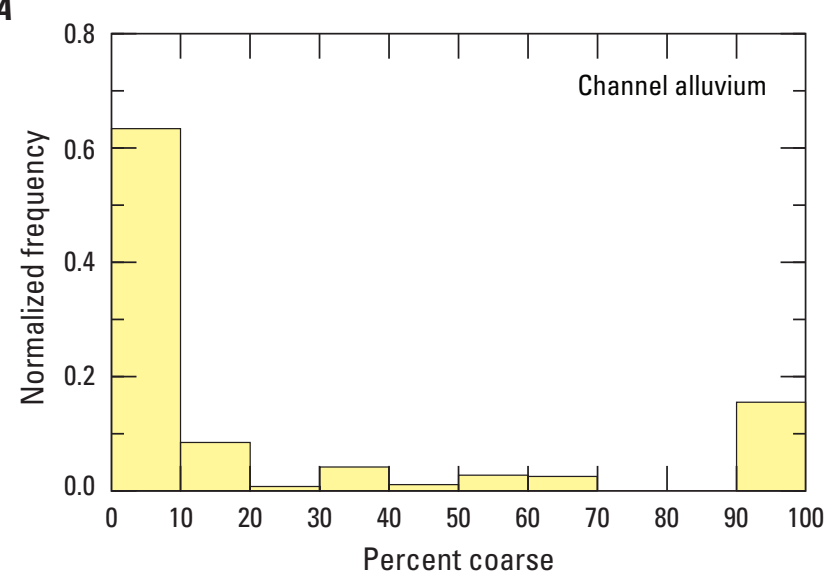

C

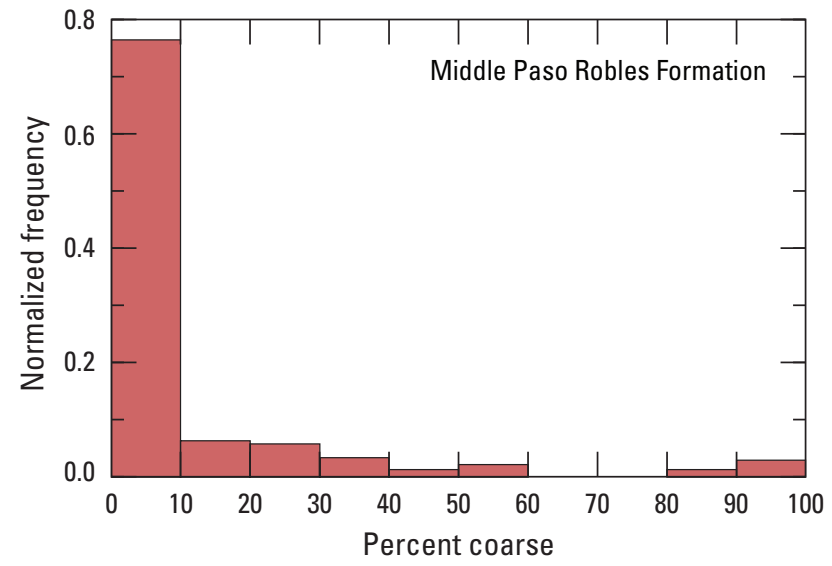

E

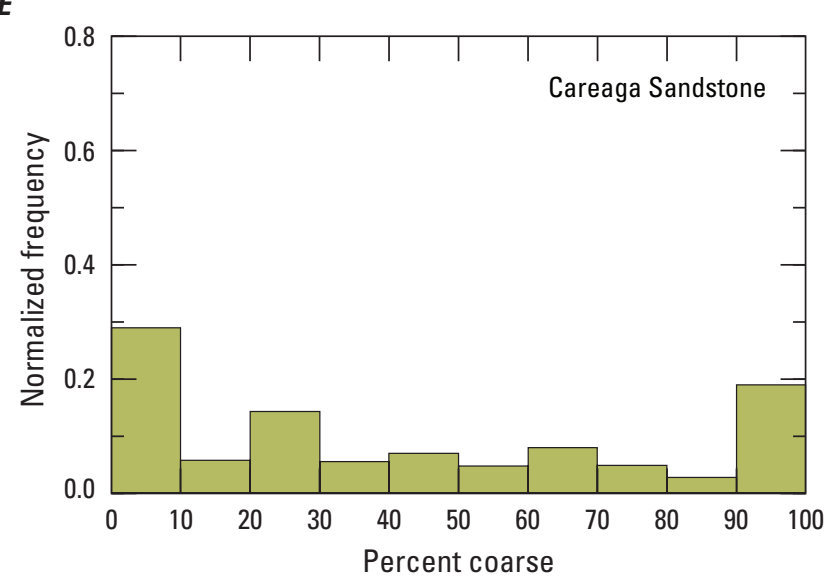

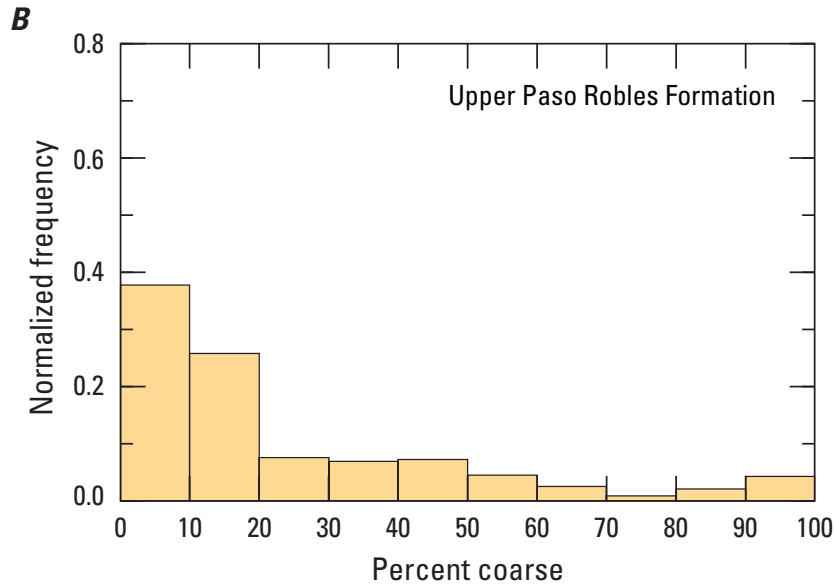

D

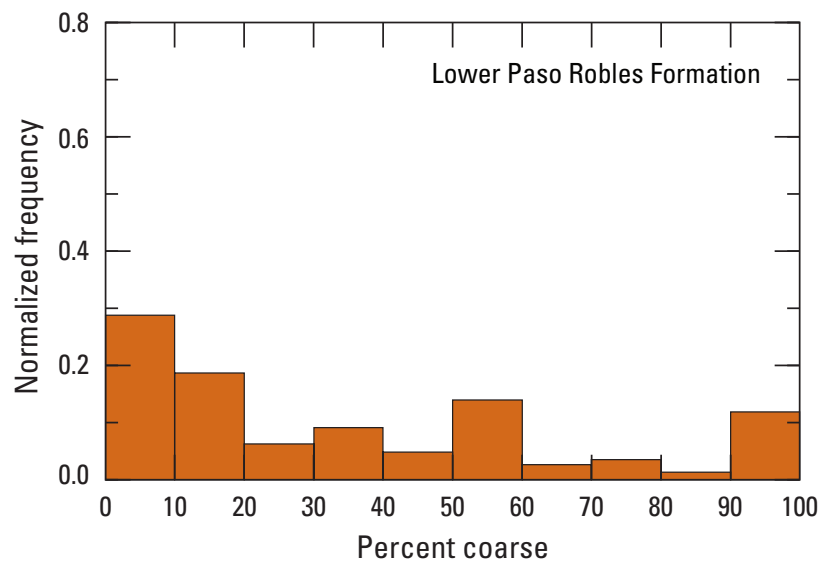

Figure 26. Frequency of coarse-grained materials, in percent, from borehole logs for basin-fill hydrogeologic units of the San Antonio Creek Valley watershed, Santa Barbara County, California (Ely and others, 2022). A, Channel alluvium; $B$, upper Paso Robles Formation; $C$, middle Paso Robles Formation; $D$, lower Paso Robles Formation; $E$, Careaga Sandstone. Frequency values are normalized by the total thickness of available borehole data in each hydrogeologic unit. 


\section{Channel Alluvium}

Channel alluvium is composed of unconsolidated gravels, sands, and clays and is located proximal to San Antonio Creek and its tributaries (fig. 17). The sedimentary materials that comprise the channel alluvium were difficult to distinguish from underlying aquifer units; therefore, the channel alluvium was assigned thicknesses based on the work of Muir (1964). In the HFM, the channel alluvium has thicknesses of about $82 \mathrm{ft}$ on the valley floor along San Antonio Creek, $50 \mathrm{ft}$ along Harris Canyon and along San Antonio Creek west of Barka Slough, and $16 \mathrm{ft}$ along all tributary streams. Channel alluvium is not considered a major aquifer because it is probably unsaturated across most of the SACVW, except along the valley floor near Barka Slough where groundwater discharges to the land surface.

Aquifer property data for channel alluvium were compiled from hydraulic conductivity results estimated from aquifer slug tests completed in select USGS single-depth, monitoring-well sites (fig. 25A; table 7), the estimated percentage of coarse-grained material from borehole logs (figs. 22E, 26A), and reported estimates of flow rate and specific capacity (Muir, 1964). Estimated hydraulic-conductivity values from aquifer slug tests at three wells along the main channel (SALS, SASA, and SAHG; figs. 17, 25A; table 7) ranged from 0.3 to $8.7 \mathrm{ft} / \mathrm{d}$. Sediment grain size in the channel alluvium, tabulated as percentage of coarse-grained texture (figs. 22E, 26A) had a distinct peak at low values of percent coarse, which could indicate deposition in a relatively low-gradient surface-water flow system on geologic timescales. Wells in channel alluvium in the eastern (upstream) part of the SACVW had average flow rates of about 350 gallons per minute (gal/min) and average specific capacities of about 13 (gal/min)/ft (Muir, 1964). Wells in channel alluvium in the western (downstream) middle part of the valley had average flow rates of about $200 \mathrm{gal} / \mathrm{min}$ and average specific capacities of about 8 (gal/ $\mathrm{min}) / \mathrm{ft}$ (Muir, 1964). Specific capacity data were not available in this unit for water wells compiled as part of this study.

\section{Lower, Middle, and Upper Members of the Paso Robles Formation}

The Paso Robles Formation is non-marine in origin, up to about 2,000 feet thick, and is identified by Muir (1964) as the main water-bearing unit in the SACVW. The Paso Robles Formation was partitioned into three informal members (lower, middle, and upper) based largely on drillers' lithology logs, geophysical logs, and hydraulic data from USGS multiple-depth, monitoring-well sites SACC and SACR (U.S. Geological Survey, 2018; Ely and others, 2022). The middle member is interpreted as a continuous fine-grained interval, while the lower and upper memebrs are coarser grained, consisting of substantial sequences of sands and gravels, with interbedded fine-grained layers (figs. 18, 20). The lower and upper members of the Paso Robles Formation provide most of the groundwater storage within the unit, while hydraulic properties of the middle member inhibit vertical groundwater flow between the upper and lower members. The middle member of the Paso Robles Formation could be related (or similar) to a regional low-permeability unit that impedes groundwater flow identified in another coastal groundwater basin about $60 \mathrm{mi}$ north of the SACVGB that is interpreted to separate the upper and lower aquifers of that basin (Cleath-Harris Geologists, 2018).

Aquifer property data for the Paso Robles Formation were compiled from hydraulic conductivity results estimated from aquifer slug tests completed in USGS single- and multiple-depth, monitoring-well sites (figs. 17, 25A; table 7; Ely and others, 2022), the estimated percentage of coarse-grained material from borehole logs (figs. $22 B-D$, $26 B-D)$, specific capacities calculated from water well driller's records (table 1.3; fig. 25B), and reported estimates of flow rate, specific capacity, and specific yield of the undifferentiated unit (Muir, 1964; Singer and Swarzenski, 1970). Measured hydraulic conductivity values from aquifer slug tests for three wells perforated in the upper Paso Robles Formation had a range of values from 0.32 to $1.0 \mathrm{ft} / \mathrm{d}$ (fig. $25 \mathrm{~A}$ ). No wells with aquifer slug tests were perforated in the middle Paso Robles Formation. Measured hydraulic conductivity values from aquifer slug tests for eight wells perforated in the lower Paso Robles Formation had a median value of $2.2 \mathrm{ft} / \mathrm{d}$, with a range of values from 0.04 to $25.0 \mathrm{ft} / \mathrm{d}$ (fig. $25 \mathrm{~A}$; table 7).

Sediment grain size, tabulated as percentages of coarse-grained texture, was estimated for the three hydrogeologic members of the Paso Robles Formation (figs. $22 B-D, 26 B-D$ ). The lower member of the Paso Robles Formation showed a broad range of percent coarse values, but the middle and upper members of the Paso Robles Formation showed distinct peaks at low values of percent coarse. Specific capacity was calculated for eleven water wells for which 60 percent of the reported perforation interval intersected with the lower, middle, or upper members of the Paso Robles Formation (fig. 25B; table 1.3). one water well was perforated in each of the middle and upper members of the Paso Robles Formation, with specific capacity values of 2.6 and $12.2(\mathrm{gal} / \mathrm{min}) / \mathrm{ft}$, respectively. Nine water wells perforated in the lower member of the Paso Robles Formation had a median specific capacity value of $3.8(\mathrm{gal} / \mathrm{min}) / \mathrm{ft}$, with a range of values from 1.78 to $17.9(\mathrm{gal} / \mathrm{min}) / \mathrm{ft}$. A well near the town of Los Alamos was reported by Muir (1964) to have a flow rate of $1,200 \mathrm{gal} / \mathrm{min}$ and a specific capacity of $12(\mathrm{gal} / \mathrm{min}) / \mathrm{ft}$. Flow rates of $500 \mathrm{gal} / \mathrm{min}$ and specific capacities of between 5 to $15(\mathrm{gal} / \mathrm{min}) / \mathrm{ft}$ were common for the Paso Robles Formation (Muir, 1964). Specific yield estimates of the Paso Robles Formation from nearby groundwater basins were estimated to be about 0.15 (Singer and Swarzenski, 1970; Miller, 1976). 


\section{Careaga Sandstone}

The Careaga Sandstone is a weakly indurated, semi-consolidated, fine-grained sandstone that may contribute to groundwater availability in the SACVW. Muir (1964) observed that this unit yielded only small quantities of water to wells and that the lack of production was attributed to the difficulty of completing wells in this poorly consolidated sand. The Careaga Sandstone may, however, yield substantial amounts of groundwater at depth (Muir, 1964).

Aquifer property data of the Careaga Sandstone were compiled from hydraulic conductivity results estimates from aquifer slug tests completed in USGS monitoring-wells SACR1 and SAHC (figs. 17, 25A; table 7; Ely and others, 2022), specific capacities calculated from water well driller's records (fig. 25B; table 1.3), the estimated percentage of coarse-grained material from borehole logs (fig. 26E), and reported estimates of permeability (Upson and Thomasson, 1951). Measured hydraulic conductivity values for two wells perforated in the Careaga Sandstone had values of 0.43 and $7.5 \mathrm{ft} / \mathrm{d}$ (fig. 25A; table 7). Sediment grain size, tabulated as percentage of coarse-grained texture, showed a broad range of percent coarse values, likely the result of averaging sediment-texture data from coarse-grained and fine-grained parts of the Careaga Sandstone (figs. 22A, 26E).Specific capacities were calculated for seventeen water wells for which at least 30 percent of the reported perforation interval intersected with the Careaga Sandstone; the median specific capacity was $4.2(\mathrm{gal} / \mathrm{min}) / \mathrm{ft}$, with a range of values from 0.3 to 83.3 (gal/min)/ft (fig. 25B). Laboratory tests by Upson and Thomasson (1951) on samples of Careaga Sandstone from the Santa Ynez River Valley groundwater basin (fig. 1) indicated an average coefficient of permeability of about 12 cubic feet per day per square foot $\left(\mathrm{ft}^{3} / \mathrm{d} / \mathrm{ft}^{2}\right)$.

\section{Consolidated Bedrock}

In the SACVW, the consolidated bedrock unit is a combination of consolidated, or highly compacted, Tertiary sedimentary rocks, including Monterey Shale, Sisquoc Formation, and Foxen Mudstone. Aquifer property data for this unit were limited; an aquifer slug test in one well (8N/34W-21A1; fig. 17; table 7) had a measured hydraulic conductivity value of $0.36 \mathrm{ft} / \mathrm{d}$ (fig $25 \mathrm{~A}$; table 7), and specific capacity data were not available in this unit for water wells compiled as part of this study. The consolidated bedrock unit contains small amounts of water in joints and fractures but does not store or transmit water in substantial quantities (Muir, 1964). For the purposes of this study, consolidated bedrock is assumed to be hydrologically homogeneous and likely provides limited, if any, contribution to the groundwater-flow system.

\section{Estimates and Sources of Recharge}

Estimates of recharge to the groundwater system have been reported as perennial yield, safe yield, or sustainable yield (Muir, 1964; Hutchinson, 1980; Martin, 1985; Gibbs, 2006; Tetra Tech, Inc., 2012). Reported estimates of natural recharge (fig. 27) were highly variable likely because of different methods of calculation and periods of investigation.

\section{Natural Recharge}

Sources of natural recharge in the SACVW are infiltration of precipitation and infiltration from streams. All estimates of natural recharge are reported for calendar years, except for those by Tetra Tech, Inc. (2012), which are for water years. Martin (1985) estimated the amount of natural recharge during early development (before calendar year 1944, not shown on fig. 27) to be about 6,200 acre-ft/yr, with average annual infiltration from precipitation and streamflow of 4,700 and 1,500 acre-ft/yr, respectively. Estimates of natural recharge to the SACVW during calendar years 1948-2018 ranged from about 5,000 to 30,000 acre-ft/yr (fig. 27). Estimates of natural recharge during calendar years 1948-80 (fig. 27) ranged from about 5,000 to 12,000 acre-ft/yr (Muir, 1964; Hutchinson, 1980; Martin, 1985; Tetra Tech, Inc., 2012); estimates of natural recharge during calendar years 1980-2010 were substantially larger, ranging from about 15,000 to 30,000 acre-ft/yr (Gibbs, 2006; Tetra Tech, Inc., 2012).

\section{Infiltration from Precipitation and Streamflow}

Estimates of infiltration from precipitation generally ranged from about 2,500 to $10,000 \mathrm{acre}-\mathrm{ft} / \mathrm{yr}$ and were assumed by previous studies to be relatively constant throughout each period of investigation (fig. 27; Muir, 1964; Hutchinson, 1980; Martin, 1985; Gibbs, 2006; Tetra Tech, Inc., 2012); the exception to this is the period of 1992-98 that included several years of above-average annual precipitation (fig. 3). Tetra Tech, Inc. (2012) estimated infiltration from precipitation to be about 19,000 acre-ft/yr during 1992-98, or about 13,000 acre-ft/yr higher than estimates for the periods before 1992 and after 1998 (fig. 27).

Estimates of infiltration from streamflow ranged from about 1,300 to 5,800 acre-ft/yr during 1948-80 and from about 9,400 to 12,600 acre-ft/yr during 1980-2010 (fig. 27). Muir (1964) and Hutchinson (1980) assumed that infiltration from streamflow was constant throughout their respective periods of investigation. Martin (1985) and Tetra Tech, Inc. (2012), however, estimated that infiltration from streamflow increased over time. Martin (1985) estimated an increase in infiltration from streamflow of about 3,200 acre-ft/yr between 1948-80 (from 1,290 to 4,520 acre-ft/yr), and Tetra Tech, Inc. (2012) estimated estimated increase of about 4,900 


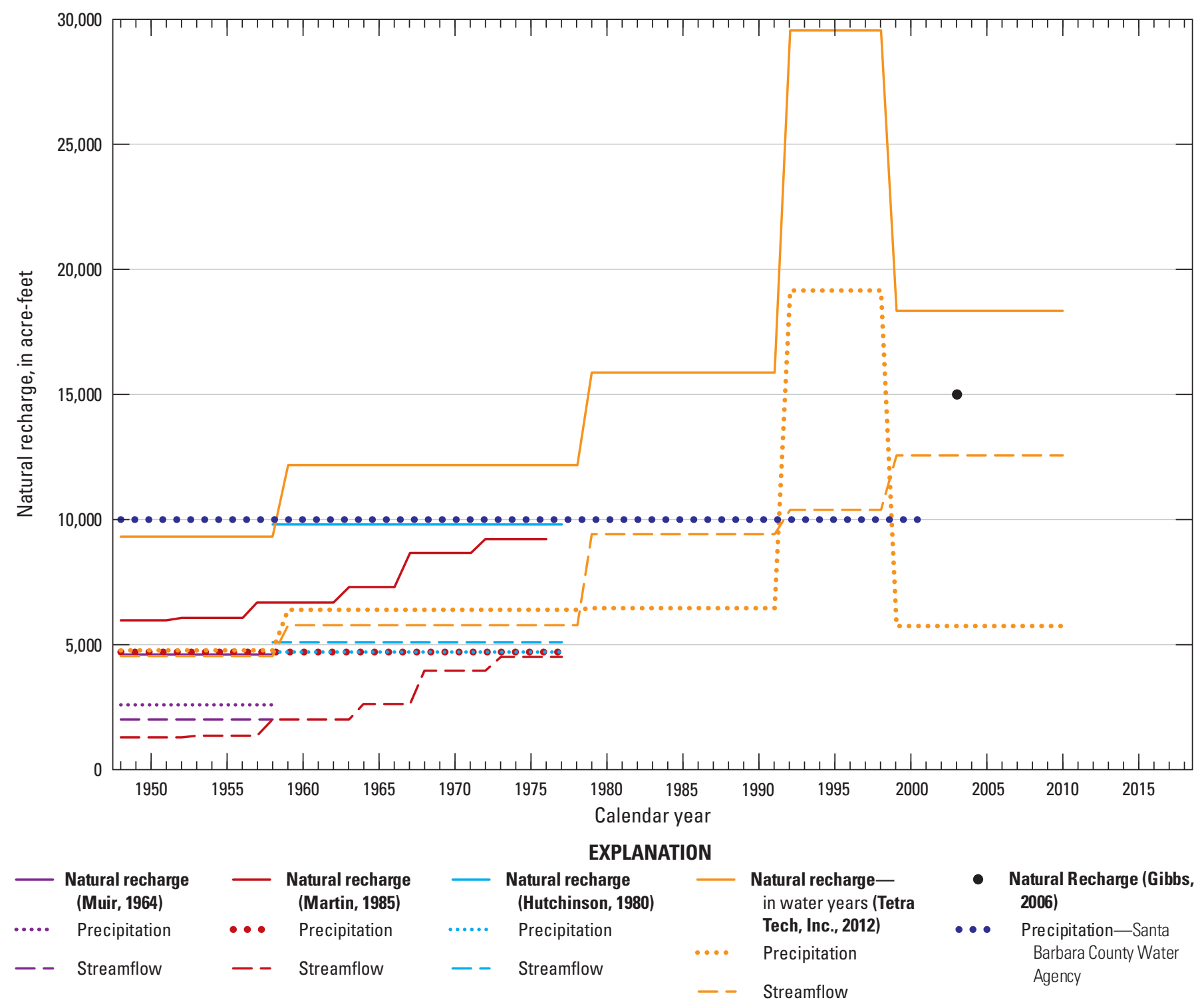

Figure 27. Reported estimates of natural recharge during calendar years 1948-2018, San Antonio Creek Valley watershed, Santa Barbara County, California.

acre-ft/yr for the same period (from 4,556 to 9,415 acre-ft/ yr). During 1980-2010, Tetra Tech, Inc. (2012) estimated an additional increase in infiltration from streamflow of about 3,200 acre-ft/yr (from 9,415 to 12,580 acre-ft/yr). Martin (1985) attributed the increase in infiltration from streamflow to increased pumpage in the stream channel along San Antonio Creek, whereby increased groundwater pumping over time and the subsequent lowering of the water table below San Antonio Creek may have created more available storage space for the infiltration of water.

\section{Subsurface Inflow}

Previous investigators have concluded that subsurface inflow from the adjacent Santa Maria River Valley and Santa Ynez River Valley groundwater basins (fig. 28) is negligible and that all groundwater recharge likely occurs within the SACVW (Muir, 1964; Hutchinson, 1980; Tetra Tech, Inc., 2012). A substantial reduction in groundwater levels in the SACVW could potentially induce subsurface inflow through saturated aquifer materials, but the topography and underlying structure of the SACVW may prevent such an occurrence. The amount and location of any subsurface inflow to the SACVW could be evaluated with a numerical model. 

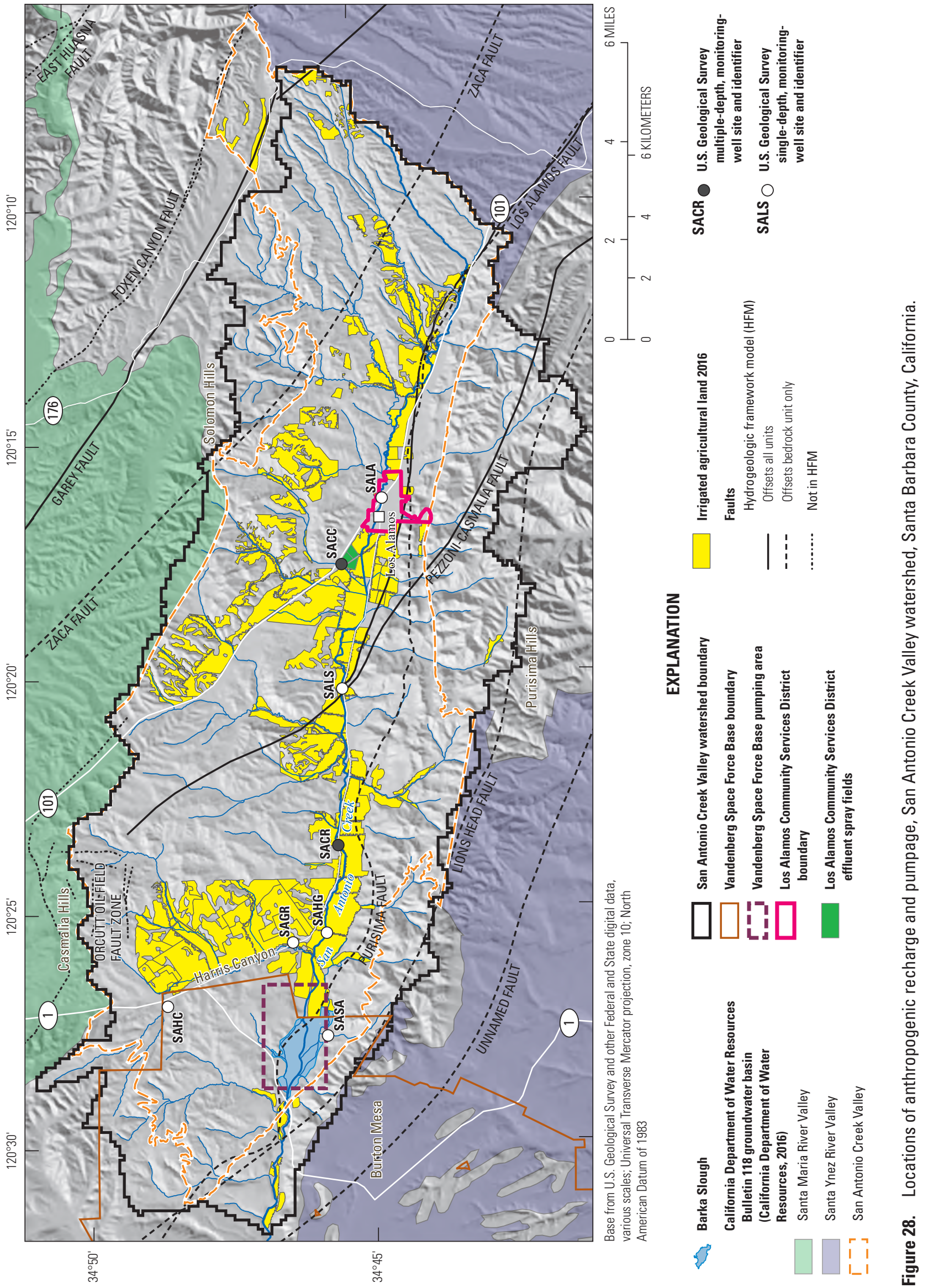


\section{Anthropogenic Recharge}

Anthropogenic recharge to the groundwater system in the SACVW comes from infiltration of wastewater effluent, agricultural irrigation return, and leakage from municipal water systems (figs. 28, 29). All estimates of anthropogenic recharge are for water years.

\section{Wastewater Effluent}

Infiltration of wastewater effluent from domestic septic systems and treatment facilities has occurred since the initial development of the area. Prior to 1988, septic tanks were the primary method for disposal of residential wastewater effluent in the SACVW (K. Barnard, Los Alamos Community Services District, written commun., 2019). In 1988, a sewer network was constructed in the town of Los Alamos. Since then, wastewater within the Los Alamos Community Services District (Los Alamos CSD) boundary area has been piped to the Los Alamos CSD wastewater treatment plant (not shown on fig. 28), and treated wastewater has been used to spray-irrigate over 66 acres of open fields adjacent to the plant (fig. 28; K. Barnard, Los Alamos Community Services District, written commun., 2019). Discharge records of the effluent used for spray irrigation have been available since 1993 (fig. 29). During 1993-2018, the amount of spray-irrigated wastewater effluent ranged from about 55 to 150 acre-ft/yr, with an average of about 110 acre-ft/yr (K. Barnard, Los Alamos Community Services District, written commun., 2019; fig. 29). The recharge from spray-irrigated wastewater effluent likely will be smaller than the applied volume because of evapotranspiration.

Recharge of wastewater effluent from septic systems before and after installation of the Los Alamos CSD wastewater treatment plant in 1988 were estimated in this study and were based on an average septic tank discharge of 70 gallons per day per person ([gal/d]/p; Umari and others, 1995). The actual amount of anthropogenic recharge from septic systems could be less after accounting for losses from evaporation of near-surface septic systems. Mills (2009) estimated a 50-percent loss rate of septic-return flow caused by evaporation and transpiration and the travel time necessary for the effluent to migrate through the unsaturated zone to the groundwater table. Prior to 1988, the entire population of the SACVW was assumed to be using septic systems for disposal of wastewater effluent. Using population estimates for the entire SACVW during 1948-87 (table 1.1) and an average septic tank discharge of 70 [gal/d] $/ \mathrm{p}$ (Umari and others, 1995), the estimated amount of potential recharge from septic effluent ranged from $41.5 \mathrm{acre}-\mathrm{ft} / \mathrm{yr}$ in 1948 to $122 \mathrm{acre-ft/yr}$ in 1987 (fig. 29). After 1988, only rural residences located outside the Los Alamos CSD boundary area (fig. 28) used septic systems; using population estimates for residents living outside of the town of Los Alamos during 1988-2018 (table 1.1), the estimated amount of potential recharge from septic effluent ranged from 35.5 acre-ft/yr in 1988 to 58.0 acre-ft/yr in 2018, with the greatest amount of potential recharge during this period occurring in 2010 (59.3 acre-ft; fig. 29).

\section{Irrigation Return Flow}

Irrigation return flow from agriculture is the amount of groundwater that has been pumped to irrigate crops but is not consumed by the plants and is subsequently returned to the groundwater system. The amount of water that is consumed through plant use and evaporation and does not return to the groundwater table is considered consumptive use. The consumptive use, or net pumpage, associated with irrigation, as well agricultural-irrigation return flow can be estimated by a numerical model using the acreage of irrigated land, reference evapotranspiration, and crop coefficients.

Recharge from agricultural-irrigation return flow in the SACVW was estimated by Muir (1964) to be about 20 percent of total agricultural pumpage., Estimates of total agricultural pumpage in the SACVW increased from about 2,800 acre-ft/yr in 1948 to about 32,000 acre-ft/yr in 2018 (see "Estimates and Sources of Discharge" section). Assuming a 20 percent return rate of agricultural pumpage, the amount of potential recharge to the groundwater system from agricultural-irrigation return flow increased from about $550 \mathrm{acre}-\mathrm{ft} / \mathrm{yr}$ in 1948 to about 6,400 acre-ft/yr in 2018 (fig. 29A).

\section{Municipal Water Systems}

Municipal water-system leakage is water that was destined for domestic and industrial use but returns to the groundwater system via leaks and cracks in the municipal piping infrastructure. Tetra Tech, Inc. (2012) reported a 13 percent rate of return flow from municipal water-system leakage. Reported and estimated amounts of municipal pumpage in the SACVW increased from about 100 acre-ft/yr in 1948 to about 280 acre-ft/yr in 2018 (see "Estimates and Sources of Discharge" section); assuming a 13 percent return rate of municipal pumpage, the amount of recharge to the groundwater system from municipal water-system leakage increased from about 13 acre-ft/yr in 1948 to about 38 acre-ft/yr in 2018 (fig. 29).

\section{Estimates and Sources of Discharge}

Groundwater is discharged from the SACVW in three primary forms: (1) evapotranspiration (ET), which is a combination of evaporation from open water along San Antonio Creek and Barka Slough, from bare soil, and transpiration from the direct uptake of water by plants, (2) groundwater pumping for agricultural, military, municipal, and domestic uses, and (3) base flow in San Antonio Creek at Barka Slough. Subsurface outflow to adjacent groundwater basins is considered negligible. 
$\boldsymbol{A}$

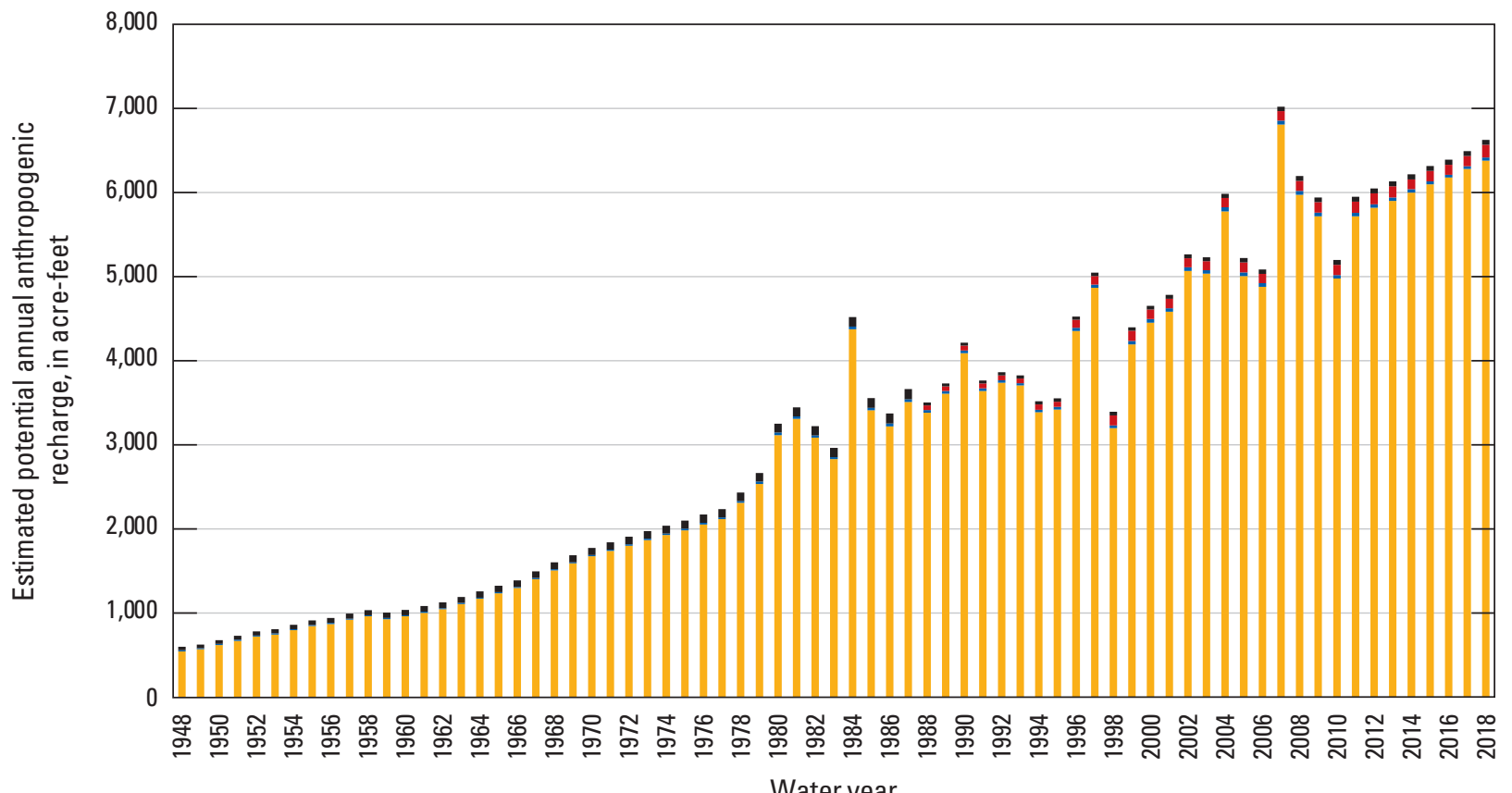

Water year

EXPLANATION

Agricultural-irrigation return

Municipal system leakage

Spray-irrigated wastewater effluent

Septic system effluent

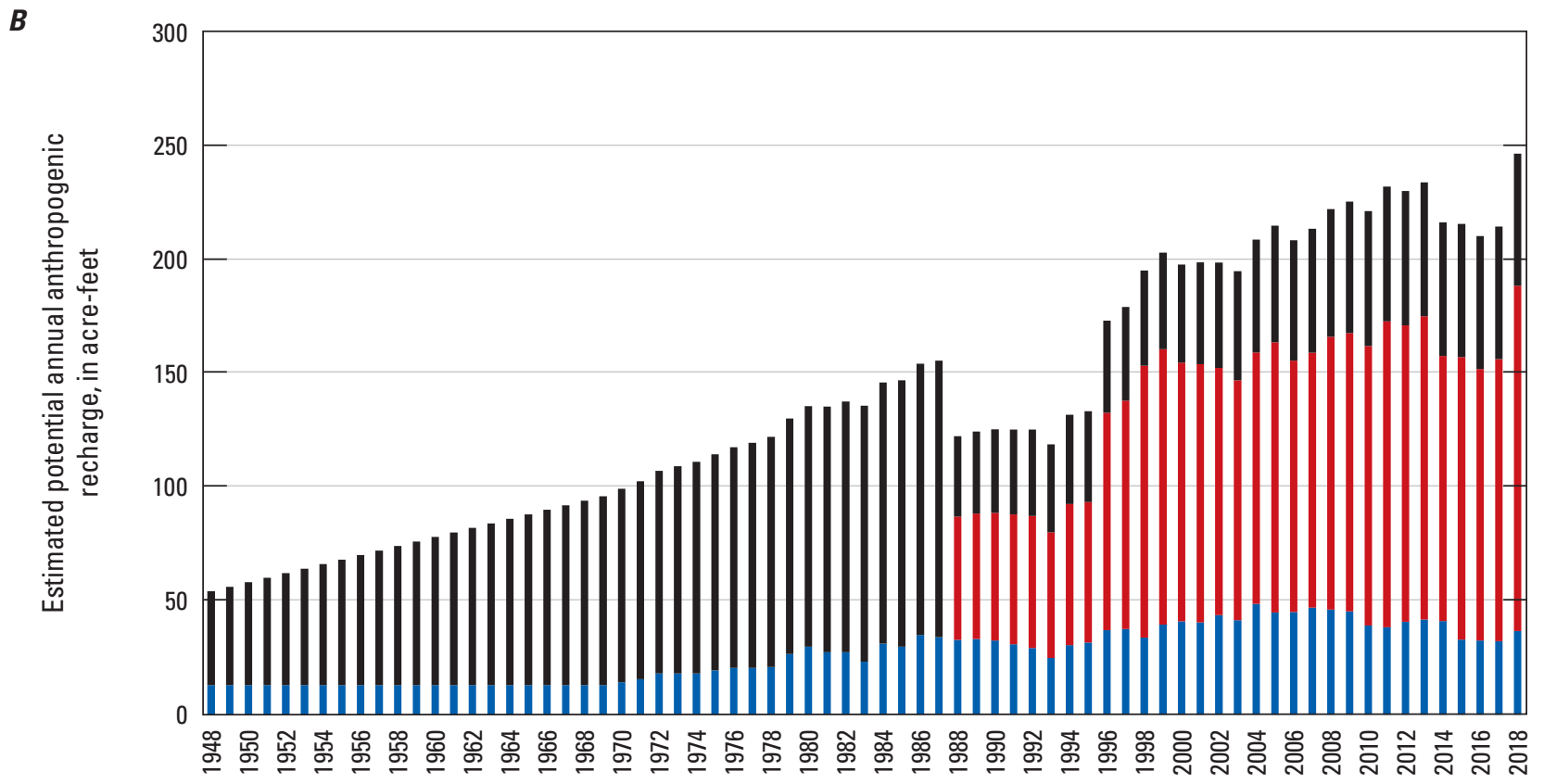

Water year

EXPLANATION

Municipal system leakage

Spray-irrigated wastewater effluent

Septic system effluent

Figure 29. Estimated annual anthropogenic recharge during water years 1948-2018: $A$, all sources of anthropogenic recharge, and $B$, sources of anthropogenic recharge not including agricultural irrigation return, San Antonio Creek Valley watershed, Santa Barbara County, California. Descriptions of how annual populations and potential annual anthropogenic recharge were estimated are included in appendix 1. 


\section{Evapotranspiration}

Evapotranspiration is the combined water loss to the atmosphere from evaporation of water and soil water and plant transpiration. ET is a function of potential evapotranspiration (PET), water availability, soil texture, vegetation type, vegetation density, and root depth. PET is the rate of ET that is possible given an unlimited supply of water under specific climatic conditions (Maidment, 1993). If water supply is limited, actual ET will be less than PET. All reported estimates of evapotranspiration are for calendar years, except for those by Tetra Tech, Inc. (2012), which are for water years.

The average reference evapotranspiration is the PET for a well-watered cropped grass surface. This value is $46.3 \mathrm{in} / \mathrm{yr}$ in the western part of the SACVW (California Irrigation Management Information System [CIMIS] zone 3) and $49.7 \mathrm{in} / \mathrm{yr}$ in the eastern part of the SACVW (CIMIS zone 6; California Irrigation Management Information System, 2005). The average total ET of chaparral, cropland, and pasture lands in the SACVW (excluding Barka Slough and San Antonio Creek) was estimated to be about 94,600 acre-ft/yr during 1958-77, and this estimate of average total ET was computed as a residual in the hydrologic budget of Hutchinson (1980).

Natural discharge from phreatophyte evapotranspiration occurs in Barka Slough and along the channel of San Antonio Creek where native vegetation habitually obtains water from areas where the groundwater table is shallow. Prior to substantial groundwater development in the SACVW (1943 and earlier; Martin, 1985), native vegetation in Barka Slough consisted predominantly of marshland plants, including cattail (Typha spp.), bulrush (Scirpus spp.), saltgrass (Distichlis spp.) and tule (Schoenoplectus acutus var. occidentalis) - these plants require abundant water and live where the depth to water is only a few inches (Mower and Nace, 1957; Martin, 1985). Native vegetation along the San Antonio Creek channel consisted of riparian cottonwood (Populus spp.) and willow (Salix spp.) trees-these plants also require abundant water but can extend their roots to deeper depths to reach the groundwater table.

Muir (1964) estimated an average ET rate of about 4.7 acre-ft/yr per acre (acre-ft/yr/acre) for marshland plants in Barka Slough, and an average ET rate of about 3.0 acre-ft/yr/acre for riparian trees along San Antonio Creek. Martin (1985) assumed that these rates were representative of pre-development conditions (1943 and earlier; Martin, 1985 ) and estimated an average total phreatophyte ET rate of 3,500 acre-ft/yr (3,100 acre-ft/yr for 660 acres of marshland at Barka Slough and 400 acre-ft/yr for 130 acres of riparian vegetation along San Antonio Creek). Muir (1964) calculated a lower rate of total phreatophyte ET of 3,000 acre-ft/yr for 1958 based on a lower amount of marshland acreage (550 acres). Tetra Tech, Inc. (2012) estimated an average total phreatophyte ET rate of 2,900 acre-ft/yr for 1935-2010 based on ET rates of 3.3 acre- $\mathrm{ft} / \mathrm{yr} / \mathrm{acre}$ for marshland in Barka Slough (670 acres) and 2.2 acre-ft/yr per acre for riparian vegetation along San Antonio Creek (700 acres).
Martin (1985) estimated reductions in the total amount of water lost through phreatophyte ET in Barka Slough and along San Antonio Creek using their groundwater-flow model; the reductions in ET were assumed to be the result of increased pumpage in the SACVW leading to a reduction in groundwater levels and available groundwater for consumptive use. The estimated phreatophyte ET rate in Barka Slough was reduced from about 3,100 acre-ft/yr in pre-development conditions (1943 and earlier) to about 1,000 acre-ft/yr in 1977, and the estimated ET rate along San Antonio Creek was reduced from about 400 to 0 acre-ft/yr during the same period (Martin, 1985). The reduction in the amount of water lost through ET at Barka Slough was consistent with an observed increase in vegetation that can survive in drier conditions, such as willow trees (Dial and Pisapia, 1980). The reduction in the amount of water lost through ET along San Antonio Creek was directly attributed to a lowering of the groundwater table below the assumed ET extinction depth (the depth at which ET ceases) of $10 \mathrm{ft}$ below land surface. Phreatophyte ET along San Antonio Creek is probably not zero in present day, despite the estimate of Martin (1985) that phreatophyte ET was 0 acre-ft/yr in 1977; satellite imagery from Google Earth (imagery date August 11, 2018; Google, Maxar Technologies 2021) show riparian vegetation along most of the entire reach of the creek, indicating that at least some groundwater is consumed by riparian vegetation.

\section{Pumpage}

Pumpage, or anthropogenic discharge, is the main mechanism by which groundwater is removed from the SACVW. Groundwater pumpage in the SACVW is used to satisfy the needs of four water-use sectors: domestic, municipal, military, and agricultural. The first domestic wells in the SACVW were developed following initial surveying of the town of Los Alamos in 1876 (Muir, 1964). Pumpage for military use by VSFB and municipal use by the Los Alamos CSD began in the mid-1900s, and pumpage for agricultural irrigation began around 1900 (Muir, 1964). Since at least the 1930s, most groundwater pumped in the SACVW has been used to satisfy agricultural water demand (Muir, 1964; Hutchinson, 1980; Martin, 1985; Tetra Tech, Inc., 2012). Total annual groundwater pumpage from the four water-use sectors during 1948-2018 increased from about 3,000 acre-ft/yr in 1948 to about 32,600 acre-ft/yr in 2018 (fig. 30; table 8).

Reported estimates of groundwater pumpage for the four water-use sectors are for calendar years and water years, depending on the data source. The sources of groundwater pumpage data, and whether the reported values are for calendar or water years, are listed in table 8 and summarized below. Estimates of domestic pumpage were for calendar years (Hutchinson, 1980; this study, see below); estimates of military pumpage were for water years (K. Domako, Vandenberg Space Force Base, written commun., 2019), except for 1963, which was for calendar year (Martin, 1985); and estimates of municipal and agricultural pumpage were for 
$\boldsymbol{A}$

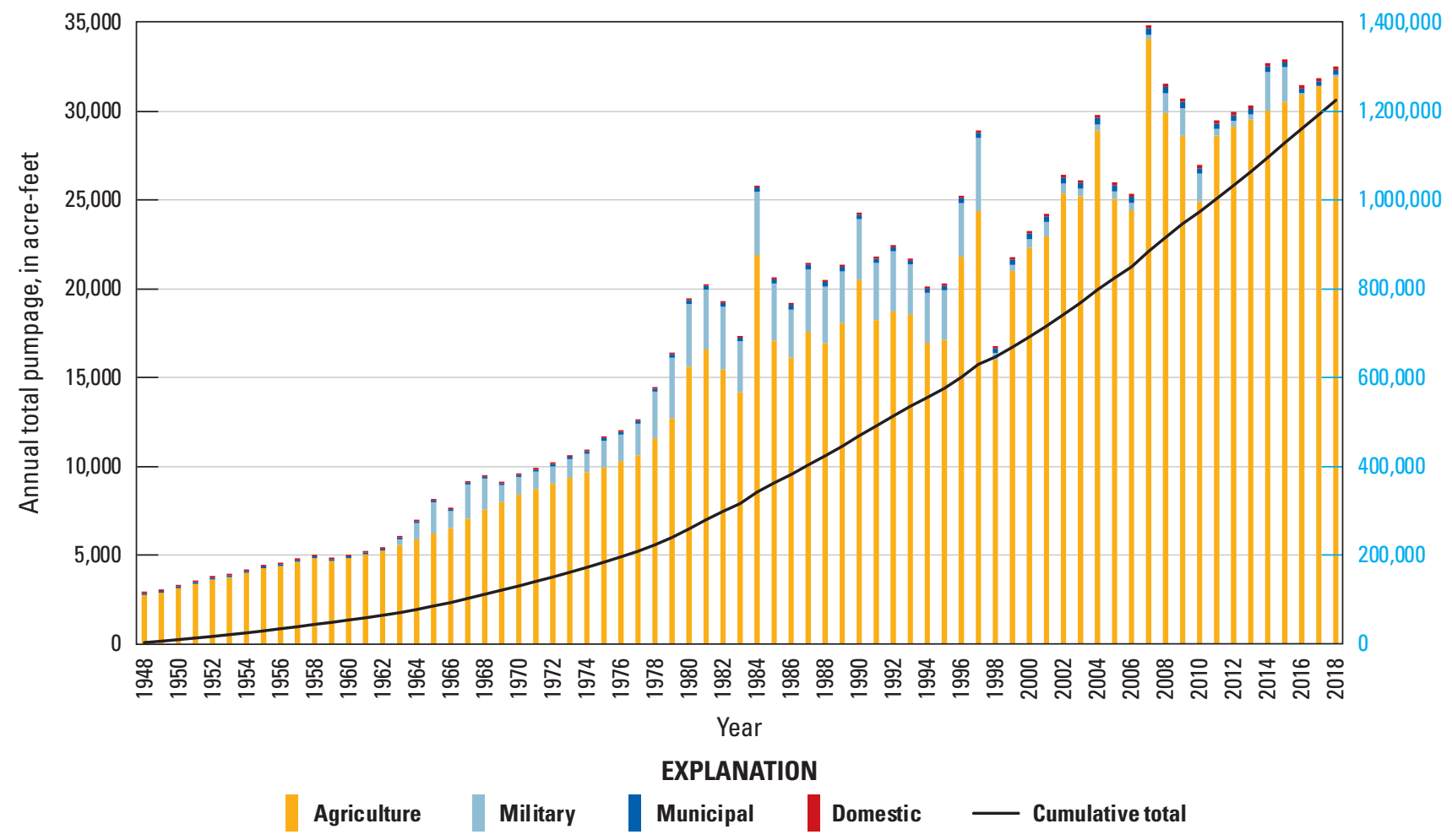

B

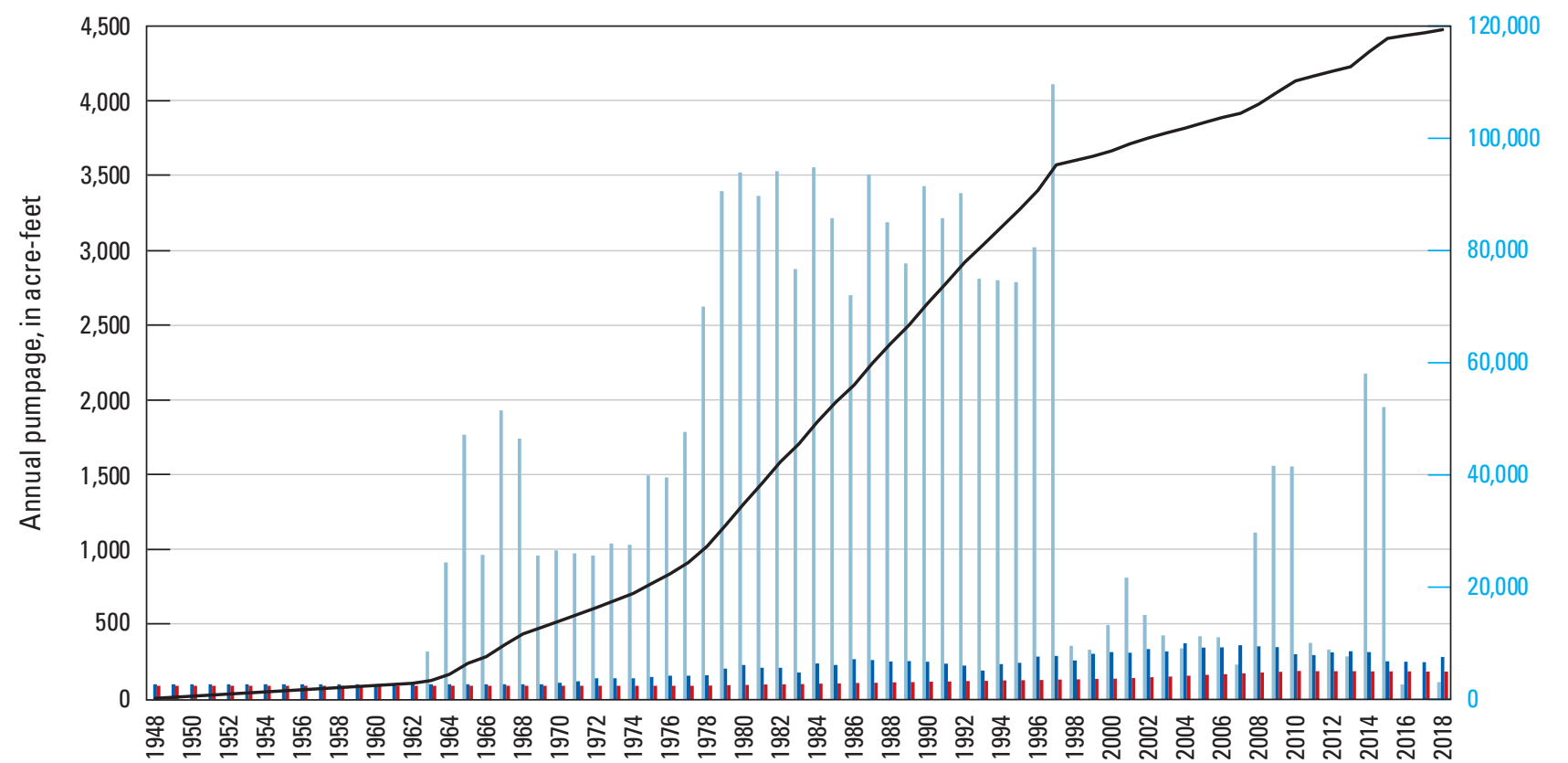

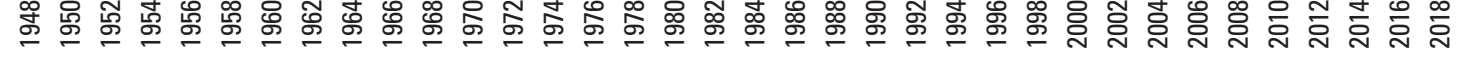
Year EXPLANATION

Military Municipal Domestic - Non-agricultural cumulative total

Figure 30. Annual and cumulative pumpage during 1948-2018, $A$, all water-use sectors; and $B$, water-use sectors not including agriculture, San Antonio Creek Valley watershed, Santa Barbara County, California. Sources of pumpage information and use of water or calendar years are listed in table 8. 
Table 8. Annual groundwater pumpage during 1948-2018, San Antonio Creek Valley watershed, Santa Barbara County, California.

[Sources of pumpage information and use of water years or calendar years are listed in the table footnotes. Pumpage values in acre-feet. Abbreviation: -, not applicable]

\begin{tabular}{|c|c|c|c|c|c|c|}
\hline Year & Agriculture $^{1}$ & Military² & Municipal $^{3}$ & Domestic $^{4}$ & $\begin{array}{c}\text { Total } \\
\text { annual } \\
\text { pumpage }\end{array}$ & $\begin{array}{c}\text { Cumulative } \\
\text { annual } \\
\text { pumpage }\end{array}$ \\
\hline 1948 & 2,750 & - & 100 & 90 & 2,940 & 2,940 \\
\hline 1949 & 2,875 & - & 100 & 90 & 3,065 & 6,005 \\
\hline 1950 & 3,125 & - & 100 & 90 & 3,315 & 9,320 \\
\hline 1951 & 3,375 & - & 100 & 90 & 3,565 & 12,885 \\
\hline 1952 & 3,625 & - & 100 & 90 & 3,815 & 16,700 \\
\hline 1953 & 3,750 & - & 100 & 90 & 3,940 & 20,640 \\
\hline 1954 & 4,000 & - & 100 & 90 & 4,190 & 24,830 \\
\hline 1955 & 4,250 & - & 100 & 90 & 4,440 & 29,270 \\
\hline 1956 & 4,375 & - & 100 & 90 & 4,565 & 33,835 \\
\hline 1957 & 4,625 & - & 100 & 90 & 4,815 & 38,650 \\
\hline 1958 & 4,825 & - & 100 & 90 & 5,015 & 43,665 \\
\hline 1959 & 4,663 & - & 100 & 90 & 4,853 & 48,518 \\
\hline 1960 & 4,825 & - & 100 & 90 & 5,015 & 53,533 \\
\hline 1961 & 5,038 & - & 100 & 90 & 5,228 & 58,760 \\
\hline 1962 & 5,250 & - & 100 & 90 & 5,440 & 64,200 \\
\hline 1963 & 5,563 & 320 & 100 & 90 & 6,073 & 70,273 \\
\hline 1964 & 5,875 & 916 & 100 & 90 & 6,981 & 77,253 \\
\hline 1965 & 6,200 & 1,770 & 100 & 90 & 8,160 & 85,413 \\
\hline 1966 & 6,513 & 965 & 100 & 90 & 7,668 & 93,081 \\
\hline 1967 & 7,038 & 1,931 & 100 & 90 & 9,159 & 102,239 \\
\hline 1968 & 7,563 & 1,744 & 100 & 90 & 9,496 & 111,735 \\
\hline 1969 & 7,975 & 962 & 100 & 90 & 9,127 & 120,862 \\
\hline 1970 & 8,400 & 996 & 110 & 90 & 9,596 & 130,458 \\
\hline 1971 & 8,713 & 976 & 120 & 90 & 9,898 & 140,356 \\
\hline 1972 & 9,025 & 962 & 140 & 90 & 10,217 & 150,573 \\
\hline 1973 & 9,350 & 1,042 & 140 & 90 & 10,622 & 161,195 \\
\hline 1974 & 9,663 & 1,033 & 140 & 90 & 10,926 & 172,121 \\
\hline 1975 & 9,938 & 1,497 & 150 & 90 & 11,674 & 183,795 \\
\hline 1976 & 10,288 & 1,484 & 158 & 90 & 12,019 & 195,815 \\
\hline 1977 & 10,600 & 1,788 & 158 & 90 & 12,636 & 208,451 \\
\hline 1978 & 11,566 & 2,626 & 161 & 92 & 14,445 & 222,896 \\
\hline 1979 & 12,696 & 3,398 & 205 & 94 & 16,393 & 239,289 \\
\hline 1980 & 15,593 & 3,523 & 230 & 96 & 19,442 & 258,731 \\
\hline 1981 & 16,562 & 3,366 & 211 & 98 & 20,237 & 278,968 \\
\hline 1982 & 15,442 & 3,531 & 211 & 100 & 19,284 & 298,252 \\
\hline 1983 & 14,162 & 2,877 & 179 & 102 & 17,321 & 315,572 \\
\hline 1984 & 21,878 & 3,557 & 240 & 104 & 25,779 & 341,352 \\
\hline 1985 & 17,064 & 3,217 & 230 & 106 & 20,617 & 361,968 \\
\hline 1986 & 16,104 & 2,701 & 269 & 108 & 19,183 & 381,152 \\
\hline 1987 & 17,555 & 3,509 & 262 & 111 & 21,437 & 402,588 \\
\hline
\end{tabular}


Table 8. Annual groundwater pumpage during 1948-2018, San Antonio Creek Valley watershed, Santa Barbara County, California. - Continued

[Sources of pumpage information and use of water years or calendar years are listed in the table footnotes. Pumpage values in acre-feet. Abbreviation: —, not applicable]

\begin{tabular}{|c|c|c|c|c|c|c|}
\hline Year & Agriculture $^{1}$ & Military² & Municipal$^{3}$ & Domestic $^{4}$ & $\begin{array}{c}\text { Total } \\
\text { annual } \\
\text { pumpage }\end{array}$ & $\begin{array}{c}\text { Cumulative } \\
\text { annual } \\
\text { pumpage }\end{array}$ \\
\hline 1988 & 16,918 & 3,189 & 253 & 113 & 20,473 & 423,061 \\
\hline 1989 & 18,047 & 2,914 & 256 & 115 & 21,332 & 444,393 \\
\hline 1990 & 20,462 & 3,431 & 251 & 117 & 24,261 & 468,654 \\
\hline 1991 & 18,218 & 3,217 & 238 & 119 & 21,792 & 490,446 \\
\hline 1992 & 18,705 & 3,385 & 225 & 121 & 22,435 & 512,881 \\
\hline 1993 & 18,549 & 2,812 & 192 & 123 & 21,676 & 534,557 \\
\hline 1994 & 16,948 & 2,802 & 235 & 125 & 20,109 & 554,666 \\
\hline 1995 & 17,113 & 2,789 & 244 & 127 & 20,273 & 574,939 \\
\hline 1996 & 21,777 & 3,022 & 286 & 129 & 25,214 & 600,153 \\
\hline 1997 & 24,353 & 4,112 & 290 & 131 & 28,886 & 629,038 \\
\hline 1998 & 16,004 & 357 & 260 & 133 & 16,755 & 645,793 \\
\hline 1999 & 20,989 & 331 & 305 & 135 & 21,761 & 667,553 \\
\hline 2000 & 22,280 & 496 & 315 & 137 & 23,229 & 690,782 \\
\hline 2001 & 22,927 & 813 & 312 & 142 & 24,195 & 714,977 \\
\hline 2002 & 25,341 & 565 & 336 & 148 & 26,390 & 741,367 \\
\hline 2003 & 25,186 & 428 & 319 & 153 & 26,086 & 767,454 \\
\hline 2004 & 28,886 & 340 & 375 & 158 & 29,759 & 797,213 \\
\hline 2005 & 25,035 & 422 & 346 & 163 & 25,966 & 823,178 \\
\hline 2006 & 24,397 & 414 & 347 & 168 & 25,327 & 848,505 \\
\hline 2007 & 34,042 & 233 & 362 & 173 & 34,810 & 883,315 \\
\hline 2008 & 29,870 & 1,115 & 355 & 179 & 31,519 & 914,833 \\
\hline 2009 & 28,590 & 1,560 & 349 & 184 & 30,683 & 945,517 \\
\hline 2010 & 24,900 & 1,557 & 301 & 189 & 26,947 & 972,464 \\
\hline 2011 & 28,600 & 377 & 296 & 188 & 29,439 & $1,001,903$ \\
\hline 2012 & 29,100 & 333 & 314 & 188 & 29,885 & $1,031,788$ \\
\hline 2013 & 29,500 & 287 & 322 & 187 & 30,318 & $1,062,106$ \\
\hline 2014 & 30,000 & 2,178 & 316 & 187 & 32,676 & $1,094,782$ \\
\hline 2015 & 30,500 & 1,954 & 254 & 186 & 32,860 & $1,127,643$ \\
\hline 2016 & 30,900 & 99 & 251 & 186 & 31,474 & $1,159,117$ \\
\hline 2017 & 31,400 & 0 & 249 & 185 & 31,845 & $1,190,962$ \\
\hline 2018 & 31,900 & 115 & 283 & 185 & 32,466 & $1,223,428$ \\
\hline
\end{tabular}

1948-57 (Martin, 1985; calendar years), 1958-77 (Hutchinson, 1980; calendar years), 1978-2010 (Tetra Tech Inc., 2012, water years), 2011-18 (this study; water years).

21963 (Martin, 1985; calendar year), 1964-2018 (K. Domako, Vandenberg Space Force Base, written commun., 2019; water years).

${ }^{3} 1958$ (Hutchinson, 1980; calendar year), 1959-75 (Martin, 1985; calendar years), 1976-92 (Gibbs, 2009; calendar years), 1993-2018 (K. Barnard, Los Alamos Community Services District, written communication, 2019; water years).

41948-76 (Hutchinson, 1980; calendar years), 1977-2018 (this study; calendar years). 
water years (Tetra Tech, Inc., 2012; K. Barnard, Los Alamos Community Services District, written communication, 2019; this study, see below) and calendar years (Hutchinson, 1980; Martin, 1985; Gibbs, 2009).

The estimated amounts of domestic pumpage (assumed to be from rural residents living outside the town of Los Alamos, see table 1.1) during 1948-2018 ranged from 90 to 189 acre-ft/yr (fig. 30; table 8). Domestic pumpage was reported to be 90 acre-ft/yr in calendar year 1976 (Hutchinson, 1980, citing Santa Barbara County Water Agency, 1977). Hutchinson (1980) assumed that the estimate from Santa Barbara County Water Agency (1977) was probably the average value for rural domestic pumpage during calendar years 1958-77. In this study, 90 acre-ft/yr is assumed to be the value for rural domestic pumpage during calendar years 1948-77. In 1976, the estimated rural residential population (people living in the SACVW but outside the town of Los Alamos) was 353 people (see appendix 1; table 1.1) assuming that domestic pumpage in 1976 was 90 acre-ft/yr, the resulting per capita water demand was $0.25 \mathrm{acre}-\mathrm{ft} / \mathrm{yr}$. For this study, the amount of rural domestic pumpage during calendar years 1978-2018 was calculated based on the estimated rural residential population of the SACVW (table 1.1) and a per capita water demand of 0.25 acre-ft/yr per person.

Reported and metered municipal pumpage during 1948-2018 ranged from 100 to 375 acre-ft/yr (fig. 30; table 8). The Los Alamos CSD is the sole purveyor of groundwater for municipal use in the SACVW and provides water to customers within its boundary area (fig. 28). The Los Alamos CSD owns five wells within its boundary area, three of which were actively pumping groundwater during water years 2007-18. Municipal pumpage compiled for this study was reported in Martin (1985) and Gibbs (2009) for calendar years 1948-75 and 1976-92, respectively, and monthly data were provided by the Los Alamos CSD for calendar years 1993-2018 (K. Barnard, Los Alamos Community Services District, written commun., 2019). The monthly municipal pumpage data provided by the Los Alamos CSD was converted to annual municipal pumpage for water years 1993-2018.

Groundwater pumpage for military use began in 1963. Groundwater is pumped from several wells in the western end of the SACVW near Barka Slough (pumping area shown in fig. 28). Military pumpage compiled for this study was reported by Martin (1985) for calendar year 1963, and monthly data were provided by VSFB for calendar years 1964-2018 (K. Domako, Vandenberg Space Force Base, written commun., 2019). The monthly military pumpage data provided by VSFB were converted to annual military pumpage for water years 1964-2018. The annual pumpage from calendar year 1963 to water year 1997 ranged from about 320 acre-ft to 4,112 acre-ft (fig. 30; table 8). In 1997, VSFB began receiving delivery of California State Water from northern California to augment its water supply, thereby reducing the amount local groundwater required to meet the demand for water (K. Domako, Vandenberg Space Force Base, written commun., 2019); during water years 1998-2018 the average annual pumpage for military use in the SACVW was about 670 acre-ft/yr (fig. 10; table 8).

Agricultural pumpage accounts for most groundwater pumpage in the SACVW, ranging from 74.9 to 98.5 percent of total annual pumpage during 1948-2018 (fig. 30A; table 8). The amount of groundwater pumpage for agricultural use increased from 2,750 acre-ft in 1948 to 31,900 acre-ft in 2018. Agricultural pumpage compiled for this study was estimated by Martin (1985) and Hutchinson (1980) for calendar years 1948-57, and 1958-77, respectively, and by Tetra Tech, Inc. (2012) for water years 1978-2010. The estimated values from Tetra Tech, Inc. (2012) included groundwater pumped for frost protection; the estimated values from Martin (1985) and Hutchinson (1980) did not include groundwater pumped for frost protection. Frost protection by overhead spray is used in the SACVW to protect grape vines from damage when the air temperature drops below freezing (Tetra Tech, Inc., 2012). Published estimates of agricultural pumpage were not available for water years 2011-18; therefore, agricultural pumpage for these years was estimated by linearly extrapolating the agricultural pumpage data from Tetra Tech, Inc. (2012) during 1978-2010 (table 8). A straight line was fitted to the pumpage data for 1978-2010 using the least squares method and then extrapolated for 2011-18 to estimate pumpage for those years. Estimated agricultural pumpage during water years 2011-18 ranged from 28,600 to $31,900 \mathrm{acre}-\mathrm{ft} / \mathrm{yr}$ (table 8).

\section{Base Flow to San Antonio Creek}

Groundwater discharges as base flow to San Antonio Creek at Barka Slough where shallow consolidated bedrock causes groundwater to rise above land surface (Martin, 1985); the discharge of groundwater as base flow to the stream channel sustains a reach of naturally occurring perennial streamflow west of Barka Slough (fig. 8).

During water years 1956-2018, estimated annual base flow at the Casmalia streamgage ranged from about 170 to 4,230 acre-ft/yr and generally declined over time (fig. 12; table 4). A Mann-Kendall test with a level of significance $(\alpha)$ of 0.05 (Helsel and Hirsch, 2002) was used to identify a statistically significant downward trend $(\mathrm{n}=50, p$-value $=0.000302)$ in the time series of base-flow estimates (fig. 12). Hutchinson (1980) and Martin (1985) estimated similar declines in base flow during calendar years 1956-77 (fig. 12) and generally attributed this decline as a response to increasing pumpage in the SACVW.

Hutchinson (1980) presented a statistical comparison of net groundwater pumpage in the basin to base flow in the San Antonio Creek groundwater basin using data from calendar years 1958 to 1977 . Hutchinson (1980) fit a line to filtered base-flow data for years with average annual precipitation, with the assumption that base flow and pumpage in these years represented "average" conditions. Years with average annual precipitation were defined by Hutchinson (1980) as having 
measured annual precipitation within plus or minus 25 percent of the long-term average annual precipitation during 1909-77. Hutchinson (1980) calculated the slope of the regression relating base flow to net pumpage to be -0.2 , meaning that for every 10,000 acre-ft/yr of net pumpage in the groundwater basin, base flow in San Antonio Creek would decline by 2,000 acre-ft/yr. Tetra Tech, Inc. (2012) evaluated base flow during 1935-2010 and concluded that the patterns in base flow were better correlated with variations in precipitation rather than pumpage and that the effect of increased pumpage in the SACVW was more likely accommodated by a decrease in groundwater storage rather than a decrease in base flow. Tetra Tech, Inc. (2012) also observed that increases in agricultural pumpage in the hills and valleys north of the valley floor, away from San Antonio Creek, likely limited the short-term influence of increasing pumpage on base flow. Variations in base flow are likely due to the delayed effects of increases in groundwater pumpage and variations in precipitation.

A statistical analysis similar to that of Hutchinson (1980) was performed for this study. A best-fit line of net annual groundwater pumpage (described below) to annual base flow (fig. 12) for water years 1956-90 (fig. 31A) and 1991-2003 (fig. 31B) provided quantitative evaluations of the effects of anthropogenic and natural influences on base flow in San Antonio Creek through time. The years 2016 to 2018 were not included in this analysis because of the substantial gap in the period of record from 2003 to 2015 (fig. 12). Best-fit line equations and coefficients of determination $\left(\mathrm{R}^{2}\right)$ for the 1956-90 and 1991-2003 periods were compared to evaluate the effects of net pumpage and base flow under different climatic conditions (fig. 31). Water years 1956-90 represent a period of alternating average and dry precipitation with occasional wet years, and water years 1991-2003 represent a period of primarily average precipitation with occasional wet years (fig. 4). Net annual pumpage was calculated as the difference between the sum of agricultural, military, municipal, and domestic pumping (fig. 30; table 8) and the sum of return flow from agricultural irrigation (20 percent of agricultural pumpage), municipal system leakage (13 percent of municipal pumpage), and wastewater effluent from spray fields and septic systems (fig. 29). Following the work of Hutchinson (1980), the statistical analyses for each period were fit to filtered data that represent years with average annual precipitation within 25 percent of the mean annual precipitation during 1948-2018 (fig. 4).

The statistical analysis of net pumpage to base flow for years with average annual precipitation during water years 1956-90 had an $R^{2}$ value of 0.82 and a p-value less than 0.00001 , indicating a statistically significant correlation between the two variables during this period (fig. 31A) based on an $\alpha$ of 0.05 . The slope of the best-fit line relating net pumpage to base flow for 1956 to 1990 was -0.080 (fig. 31A), meaning that for every 10,000 acre-ft of net pumpage in the SACVW, base flow in San Antonio Creek would decline by 800 acre-ft. This estimated rate of base-flow decline was less than half of that calculated by Hutchinson (1980) for the
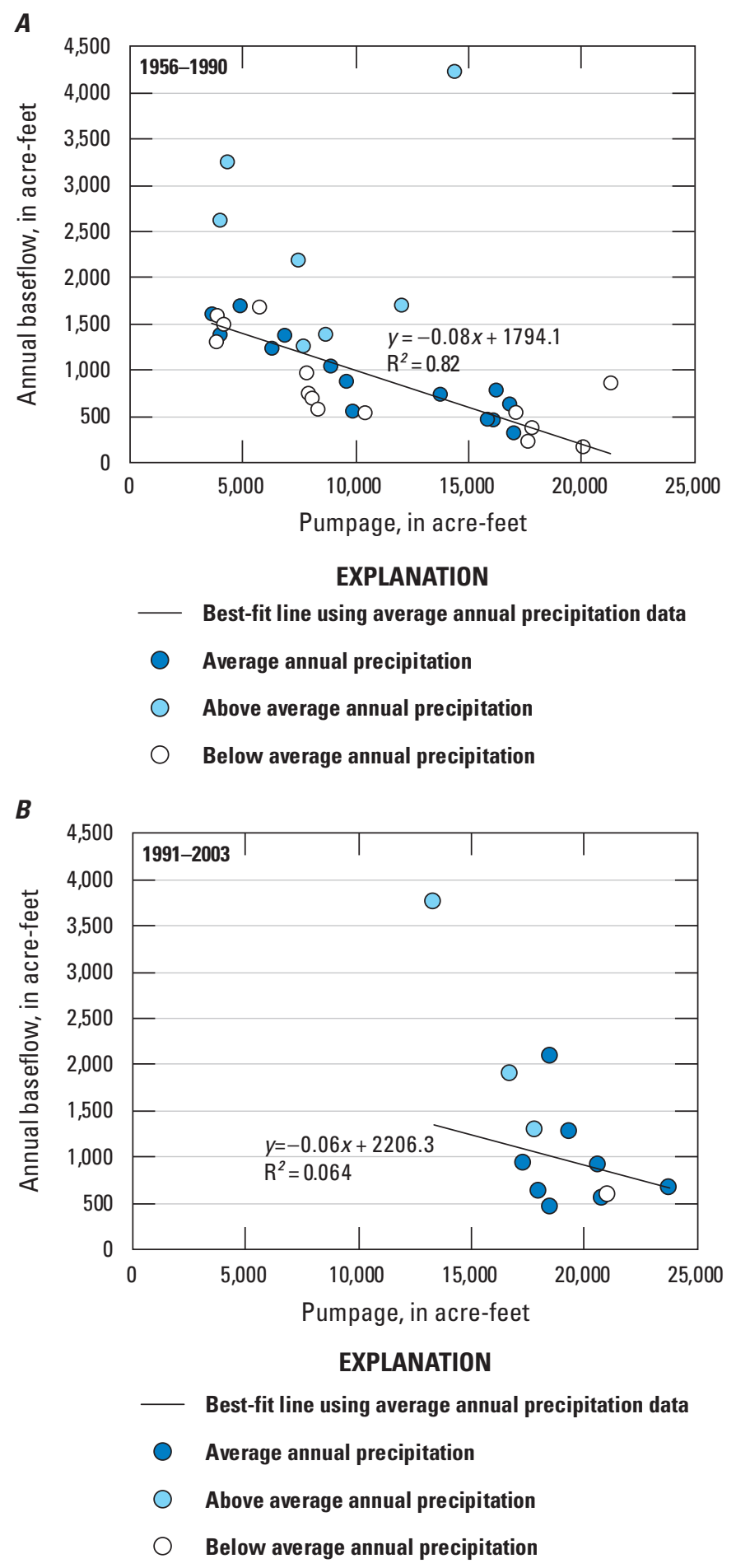

Figure 31. Best-fit line equations and coefficients of determination $\left(R^{2}\right.$ values) that describe relations between net annual pumpage and annual base flow at U.S. Geological Survey station 11136100 during years with average annual precipitation (within plus or minus 25 percent of the average annual precipitation from 1948 to 2018; represented by blue dots) for $A$, water years 1956-90; and $B$, water years 1991-2003, San Antonio Creek Valley watershed, Santa Barbara County, California. Sources of pumpage information and use of water or calendar years are listed in table 8. 
period 1958-77. The longer period of 1956 to 1990 (fig. 31A) may better demonstrate the long-term effects of net pumpage on base flow, while the shorter period of 1958 to 1977

(Hutchinson, 1980) may have been influenced by a few dry precipitation years at the end of that period $(1969,1970-72$; fig. 4) and had a more limited set of available data than for the longer period. A steady decline in base flow during 1956-90 was associated with an increase in total pumpage from about 4,600 acre-ft/yr to about 24,300 acre-ft/yr (figs. 12, 30, 31); this period had mostly average and dry years of precipitation (only 7 of 34 years in this period were classified as wet years; fig. 12). Most of the pumpage in the SACVW was agricultural along the middle of the valley, proximal to San Antonio Creek (figs. 6, 30). The increase in agricultural pumpage was due to an increase in agricultural acreage (from 8,674 acres in 1959 to 9,838 acres in 1986) and a shift in farming practices to irrigated crop land (the amount of irrigated cropland increased from 2,118 acres in 1959 to 7,923 acres in 1986). The correlation of net pumpage to base flow for this period is indicative of the influence of groundwater pumping on base flow in the SACVW during periods of primarily average and dry climatic conditions.

The statistical analysis of net pumpage to base flow for years with average annual precipitation during water years for 1991-2003 had an $\mathrm{R}^{2}$ value of 0.063 and a p-value of 0.55 , indicating that correlations between the two variables were not statistically significant during this period (fig. $31 B$ ). The slope of the best-fit line relating net annual pumpage to base flow was -0.064 (fig. $31 B$ ), meaning that for every 10,000 acre-ft/yr of net pumpage in the SACVW, base flow in San Antonio Creek would decline by $640 \mathrm{acre}-\mathrm{ft} / \mathrm{yr}$. This estimated rate of base-flow decline was less than values for 1956 to 1990 (fig. 31A) and for 1957 to 1977 (Hutchinson, 1980). The period of 1991 to 2003 was associated with relatively steady base-flow values with punctuated increases in annual base flow during wet years (figs. 12, 31B), a relatively moderate increase in total pumpage from about 22,000 acre-ft/yr to about 26,000 acre-ft/yr (fig. 30; table 8), and mostly average and wet years of precipitation (only 2 of 12 years in this period were classified as dry years). The relatively moderate increase in pumpage over this period, and smaller slope of regression, was in response to relatively high amounts of precipitation and the likely resulting reduction in water demand for crops despite the overall increase in agricultural acreage, all of which was irrigated cropland (from about 10,300 acre-ft/yr in 1996 to about 14,200 acre-ft/yr in 2006; fig. 6; table 2). Agricultural lands generally increased in the northern hills and valleys away from San Antonio Creek (fig. 6). The poor correlation between net pumpage and base flow for this period indicates the influence of climatic variations on base flow in the SACVW during periods of average and wet climate; the groundwater system is sensitive to changes in precipitation because the SACVW is relatively shallow and narrow.

\section{Subsurface Outflow}

Groundwater underflow to the neighboring Santa Maria River Valley and Santa Ynez River Valley groundwater basins (fig. 28) was assumed to be negligible (Hutchinson, 1980; Martin, 1985). Tetra Tech, Inc. (2012) observed that groundwater-level data across the SACVW boundary with adjacent groundwater basins were consistent with previous conclusions that subsurface outflow from the SACVW was unlikely. If hydrologically connected, a substantial lowering of groundwater levels in the neighboring Santa Maria River Valley and Santa Ynez River Valley groundwater basins could potentially induce subsurface underflow from the SACVW through saturated aquifer materials, but the topography and underlying structure of the SACVW would likely prevent such an occurrence. The amount and location of any subsurface outflow from the SACVW can be estimated with a numerical model based on groundwater-head differences across the boundary of the SACVW.

\section{Groundwater Levels, Flow, and Movement}

Groundwater-level data were compiled and collected to evaluate spatial and vertical variations in groundwater levels and to identify the sensitivity of the aquifer system to seasonal changes in climatic and pumping conditions. Additional groundwater-level measurements were made available through the installation and construction of eight new multiple- and single-depth, monitoring-well sites by the USGS (fig. 16; table 9; appendix 1). With a few exceptions, groundwater levels were measured as part of this study in wells from early 2017 through June 2019. Manual groundwater-level measurements were collected approximately quarterly from 55 wells (including all wells at the eight USGS singleand multiple-depth, monitoring-well sites); continuous groundwater-level measurements were collected at 18 wells (including all wells at the eight USGS monitoring-well sites and one previously installed multiple-depth, monitoring-well site near Barka Slough; 8N/34W-16C1-4; table 9). The continuous monitoring sites were equipped with pressure transducers that recorded hourly measurements that were regularly downloaded and processed to calculate groundwater levels. Wells measured as part of this study are listed in table 9. Groundwater-level and water-quality data are available from the USGS NWIS database at https://nwis.waterdata.usgs.gov/nwis by searching for the USGS Site Number (U.S. Geological Survey, 2021).

The historical reliance on groundwater in the SACVW for agricultural, military, and municipal use has caused changes to the depth of groundwater since the mid-1900s. In general, the direction of groundwater flow in the SACVW is from the Solomon Hills, Casmalia Hills, and Purisima Hills to San Antonio Creek and Barka Slough (fig. 32). This general direction of flow was the same during early development conditions (1944 to 1948; fig. 32A), mid-development conditions (1948-78; fig. 32B), and expanded-development 


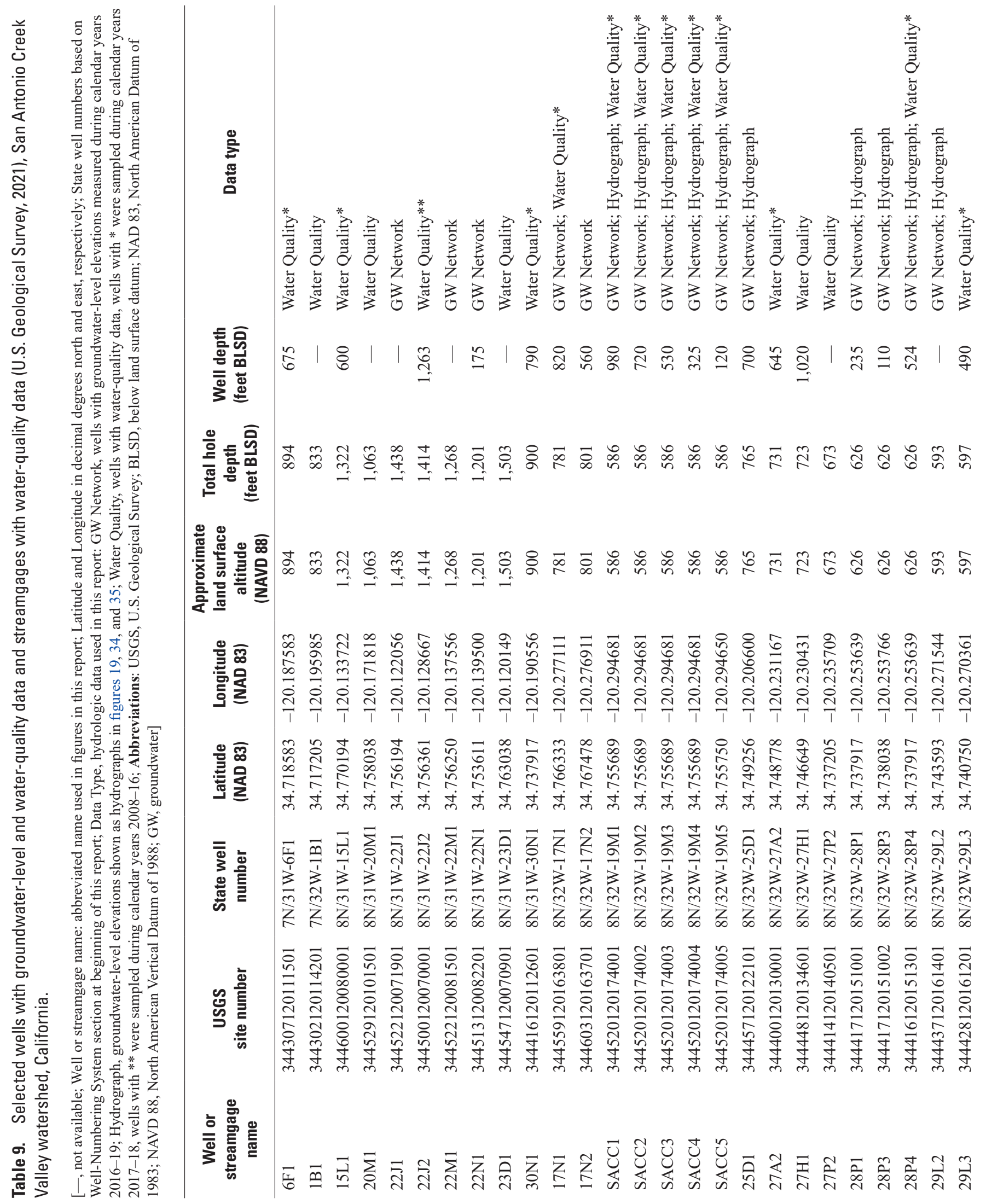




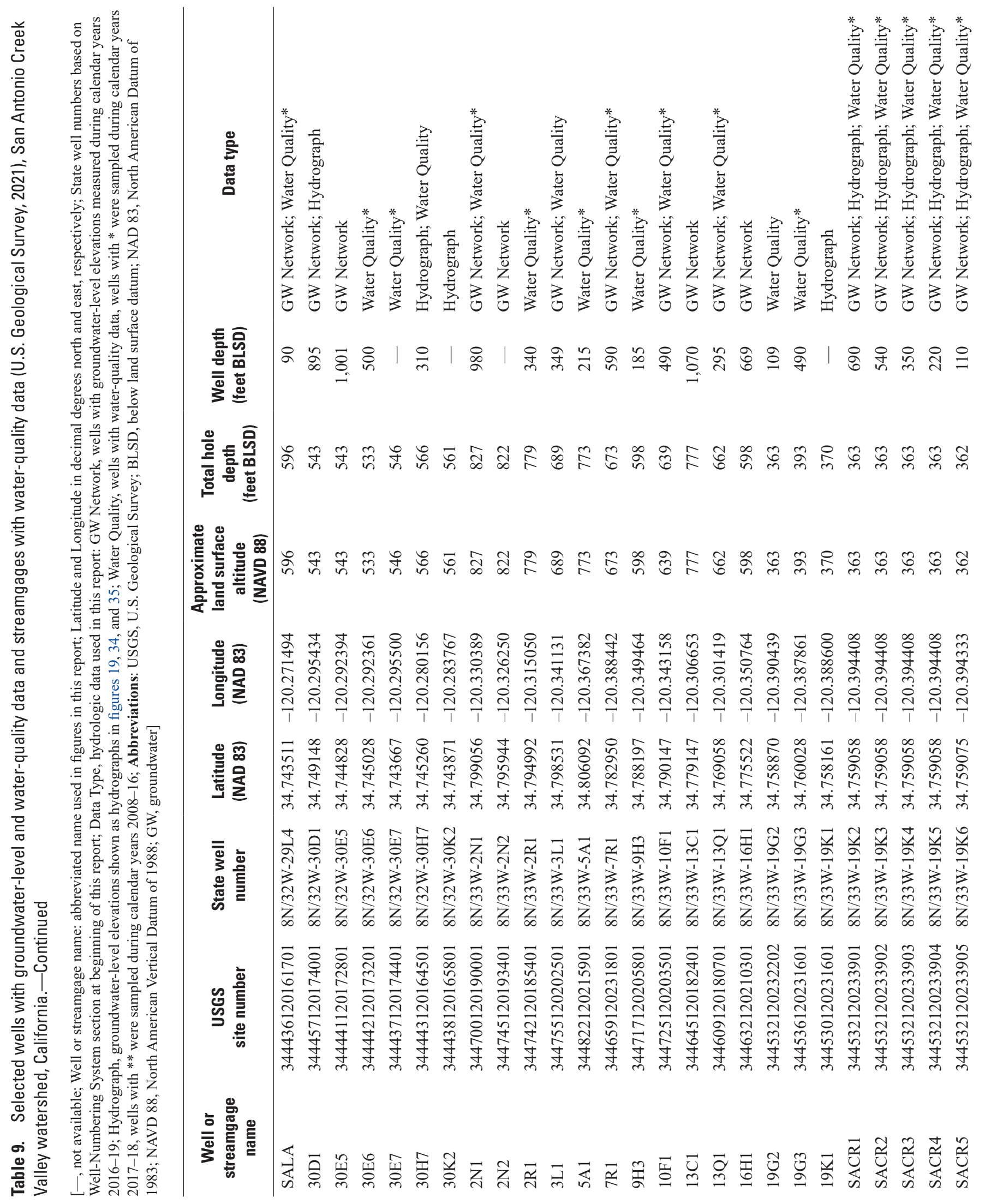



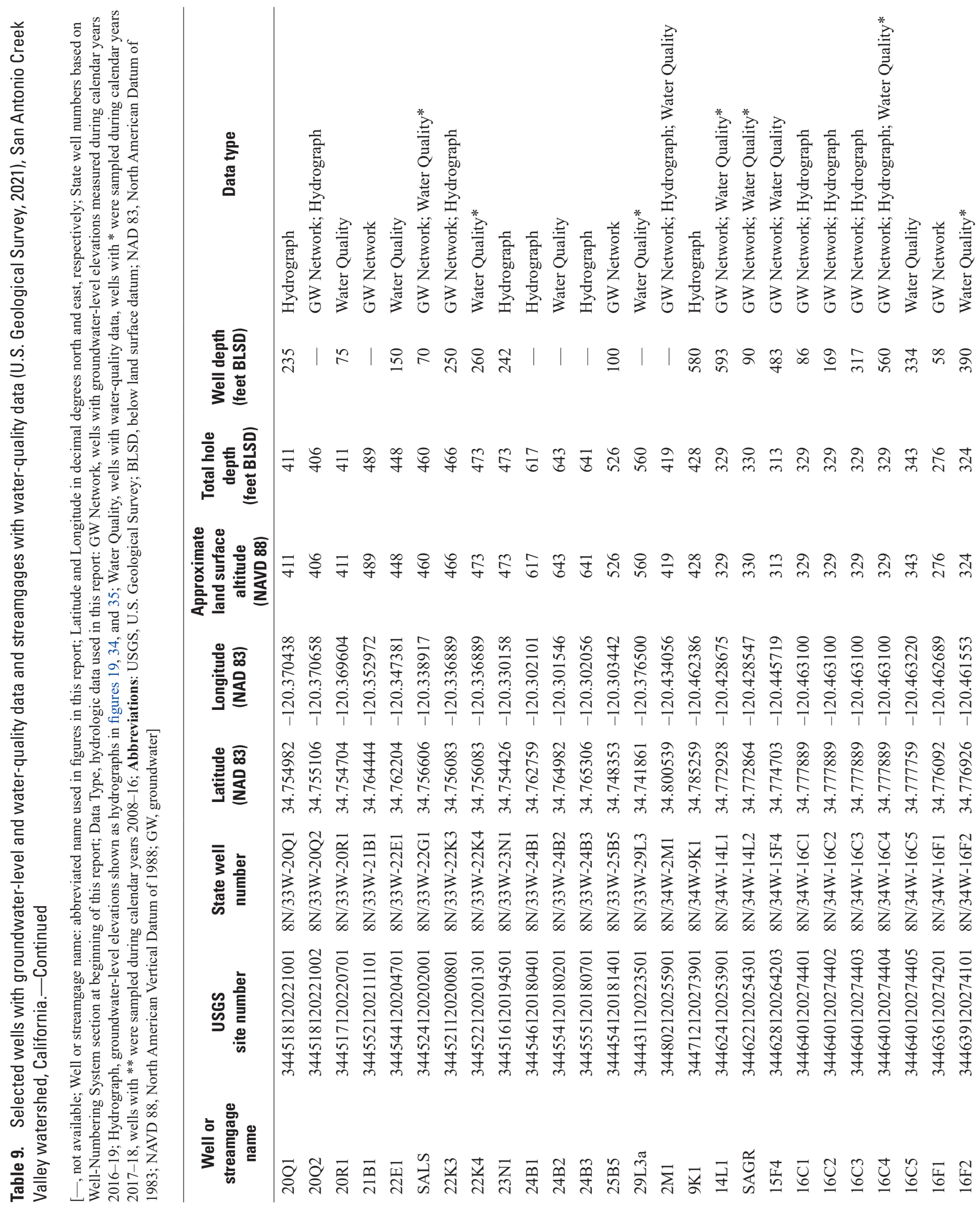


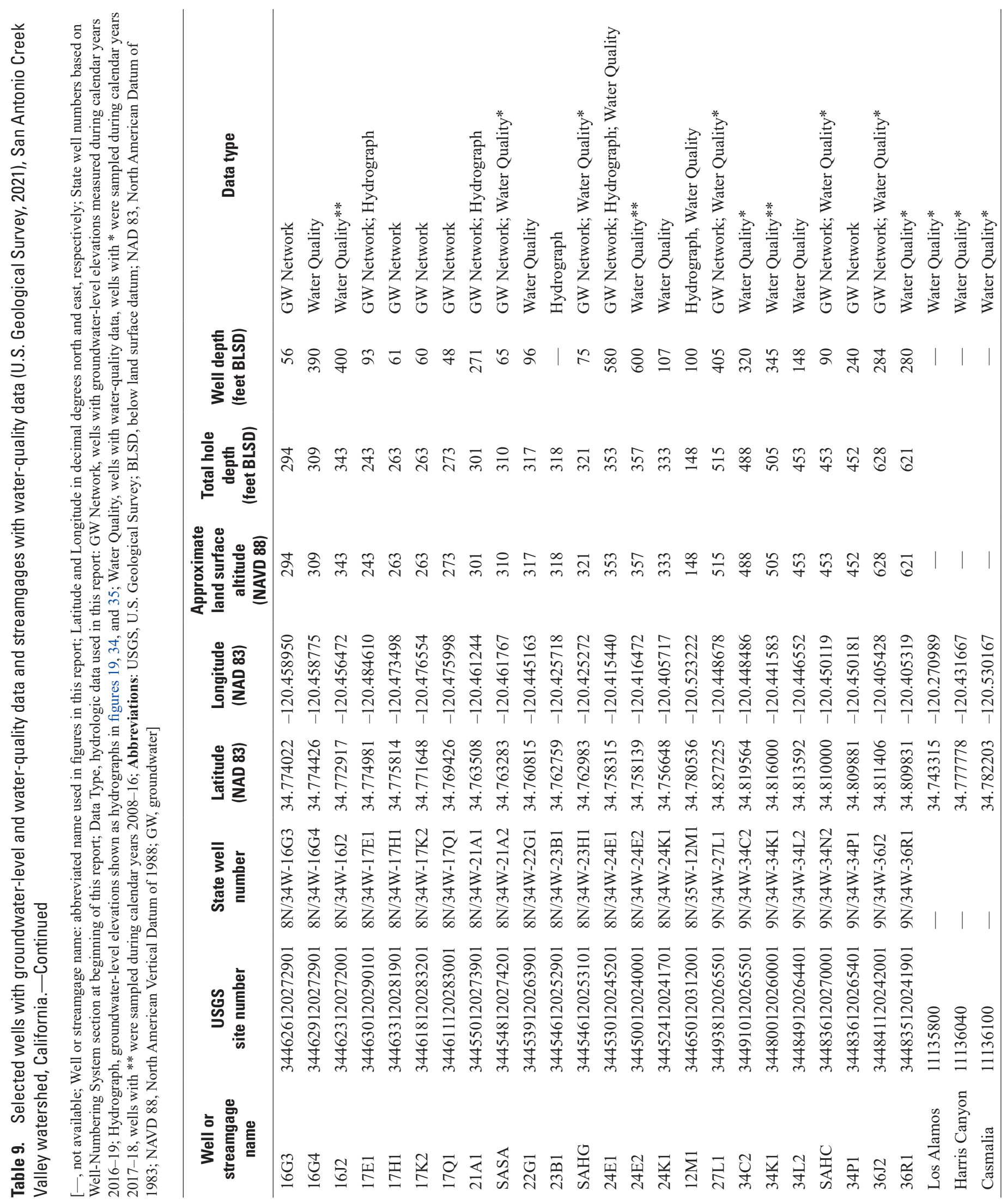



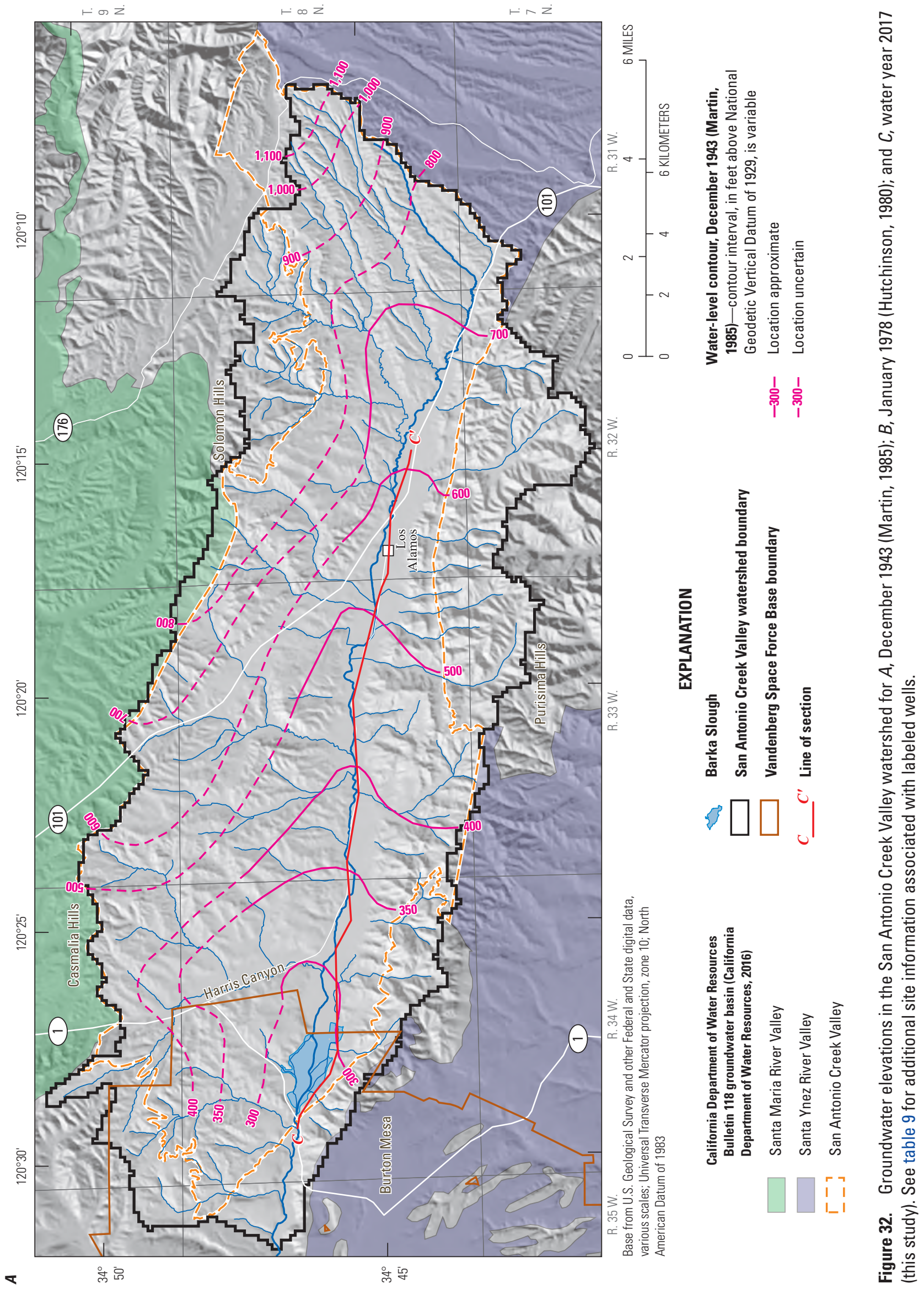

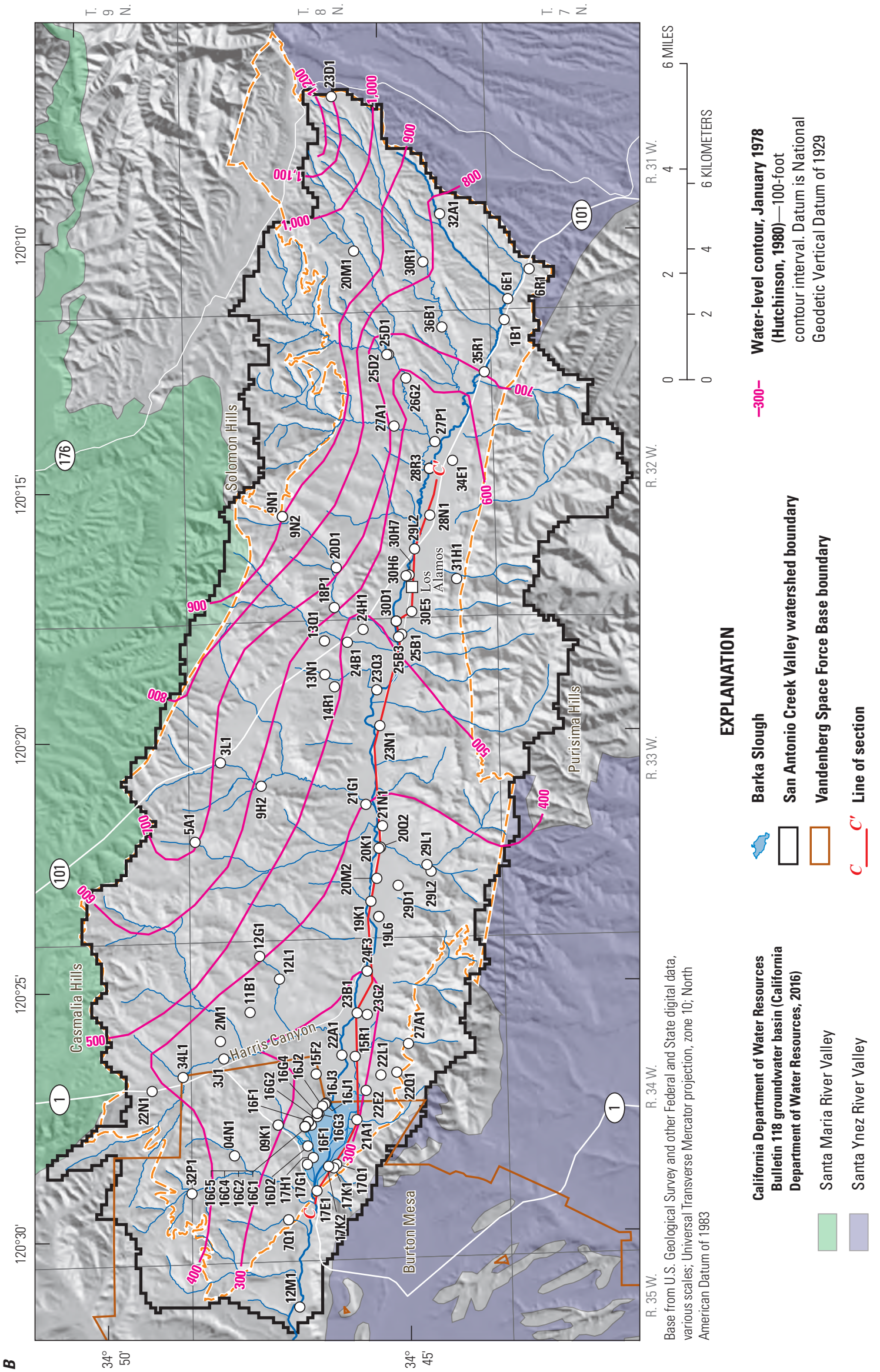

$\infty$

品它

过 辇

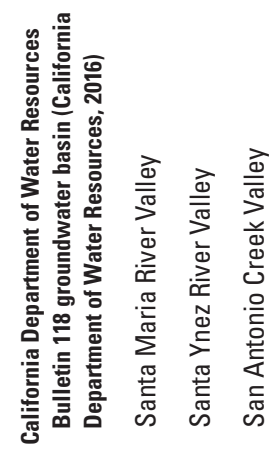

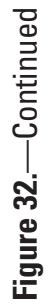



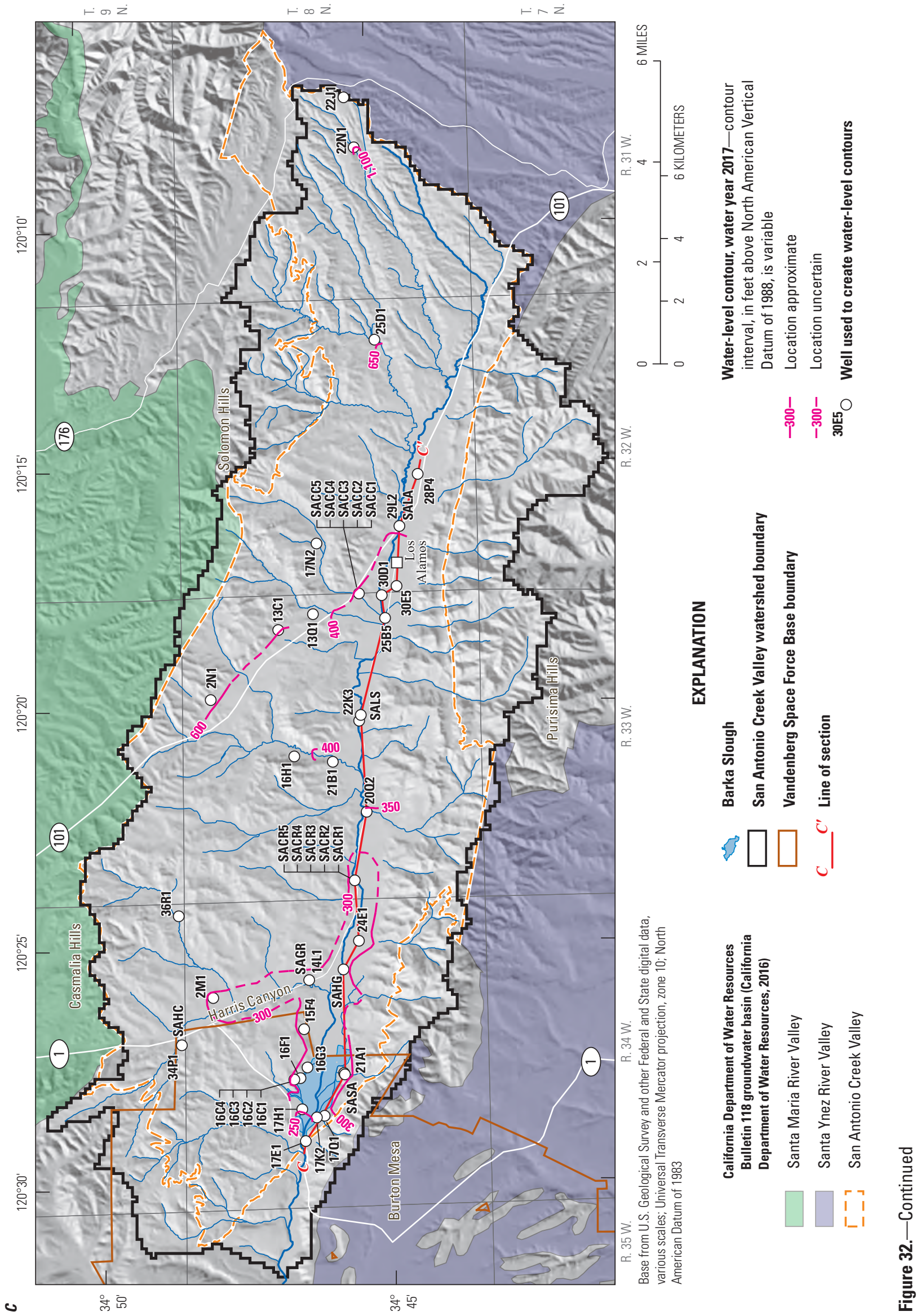
conditions (1979-2018; fig. 32C), but groundwater levels have generally declined from period to period. Groundwater discharge at Barka Slough has persisted over each developmental period; however, the amount of base flow has decreased through time as a result of increased pumpage in the SACVW (see "Base Flow to San Antonio Creek" section). Contour maps of groundwater elevation for December 1943 (Martin, 1985; fig. 32A), January 1978 (Hutchinson, 1980; fig. 32B), and water year 2017 (this study; fig. 32C) show changes in groundwater elevation caused by changing patterns of water use and climatic conditions.

Prior to 1948, groundwater extraction in the SACVW was minimal; groundwater pumpage for agricultural use was supplied by up to 39 irrigation wells (Muir, 1964), and pumpage for municipal and domestic water use only needed to supply an estimated population of less than about 500 people (table 1.1). Muir (1964) produced a map of groundwater elevations of the SACVW for December 1943 and observed that, over their period of investigation, the groundwater table was the highest on record. Martin (1985) redrafted the contour map of Muir (1964; fig. 32A) and considered the high groundwater elevations of December 1943 to be representative of steady-state (natural) conditions. The December 1943 groundwater elevation contour map shows that groundwater flowed from recharge areas in the surrounding Solomon and Casmalia Hills, and the Purisima Hills, to the southwest and northwest, respectively. An area of groundwater discharge is indicated by the trough in the groundwater elevation contours along San Antonio Creek from near the town of Los Alamos to Barka Slough. Prior to 1947, flowing wells were present near the town of Los Alamos along a 2-mile stretch of San Antonio Creek, from just east of the town of Los Alamos to about 2 miles west of the town. Groundwater elevations for December 1943 ranged from higher than $1,100 \mathrm{ft}$ above the National Geodetic Vertical Datum of 1929 (NGVD 29) at the northeastern boundary of the SACVW to slightly less than $300 \mathrm{ft}$ above NGVD 29 at Barka Slough, where groundwater elevation was at or above land surface (fig. 32A). Groundwater gradients adjacent to the eastern boundary of the SACVW sloped steeply from more than $1,100 \mathrm{ft}$ to about $700 \mathrm{ft}$ above NGVD 29 toward the valley floor east of Los Alamos, and flattened along the valley floor, decreasing from about $700 \mathrm{ft}$ above NGVD 29 east of Los Alamos to less than $300 \mathrm{ft}$ above NGVD 29 at Barka Slough (a gradient of about 30 feet per mile [ft/mi]; Martin, 1985).

Since the early 1940s, groundwater levels have declined (figs. 32B, 32C). By the early 1970s, increases in pumpage exceeded most estimates of recharge rates (figs. 27, 30) in response to the expansion of agriculture, the onset of military pumpage by VSFB, and the increase in population, resulting in a decline in groundwater levels throughout the SACVW and changes to localized artesian conditions. The general direction of groundwater flow in January 1978 had the same general character as in December 1943, flowing from recharge areas in the Solomon Hills, Casmalia Hills, and the Purisima Hills toward San Antonio Creek and then east to west along the creek to Barka Slough (fig. 32B). Groundwater elevations for January 1978 at the eastern boundary of the SACVW, and near Barka Slough, were similar to groundwater elevations for December 1943 and ranged from higher than 1,200 ft above NGVD 29 to less than $300 \mathrm{ft}$ above NGVD 29 (figs. 32A, $32 B$ ), with groundwater elevations at or above land surface at Barka Slough (fig. 33). Groundwater elevations generally declined along the valley floor (figs. 32A, 32B); elevations declined east of Barka Slough, but the greatest decline of more than about $50 \mathrm{ft}$ was east of Los Alamos (fig. 33). The depth to groundwater increased enough by 1958 that the flowing wells observed by Muir (1964) near Los Alamos had ceased flowing. The groundwater gradient in 1978 from the valley floor east of Los Alamos (about $600 \mathrm{ft}$ asl) to Barka Slough (less than $300 \mathrm{ft}$ asl) was about $25 \mathrm{ft} / \mathrm{mi}$ (Hutchinson, 1980).

Groundwater pumpage steadily increased during 1979-2018, culminating in a period of 12 years (2007-18) with the highest estimated annual pumpage, often exceeding 30,000 acre-ft/yr (fig. 30A; table 8). Groundwater elevations in the SACVW for water year 2017 indicate further declines in groundwater elevations since December 1978, especially along the valley floor (figs. 32C, 33) and in upland areas where agriculture has expanded (such as along Harris Canyon; fig. 6). The water year 2017 groundwater-elevation contour map was constructed based on the shallowest groundwater measurements for wells sampled during the year (fig. 32C). The number and extent of groundwater-elevation contours for 2017 are fewer and more limited in extent than the contours for January 1978 (figs. 32B) because fewer groundwater-level measurements were available. The general direction of groundwater flow in the SACVW was similar in 2017 and January 1978. By 2017, groundwater elevations declined between about 50 to $150 \mathrm{ft}$ on the valley floor along San Antonio Creek; the greatest declines were near and east of Los Alamos (figs. 32B, 32C, 33). At the western end of Barka Slough, groundwater elevations declined below land surface (fig. 33). Groundwater elevations in the upland areas north of San Antonio Creek also declined between about 50 to $100 \mathrm{ft}$. The hydraulic gradient from the valley floor east of Los Alamos (about $400 \mathrm{ft}$ above NAVD 88) to Barka Slough (about $250 \mathrm{ft}$ above NAVD 88) was about $13 \mathrm{ft} / \mathrm{mi}$ (fig. 32C). 


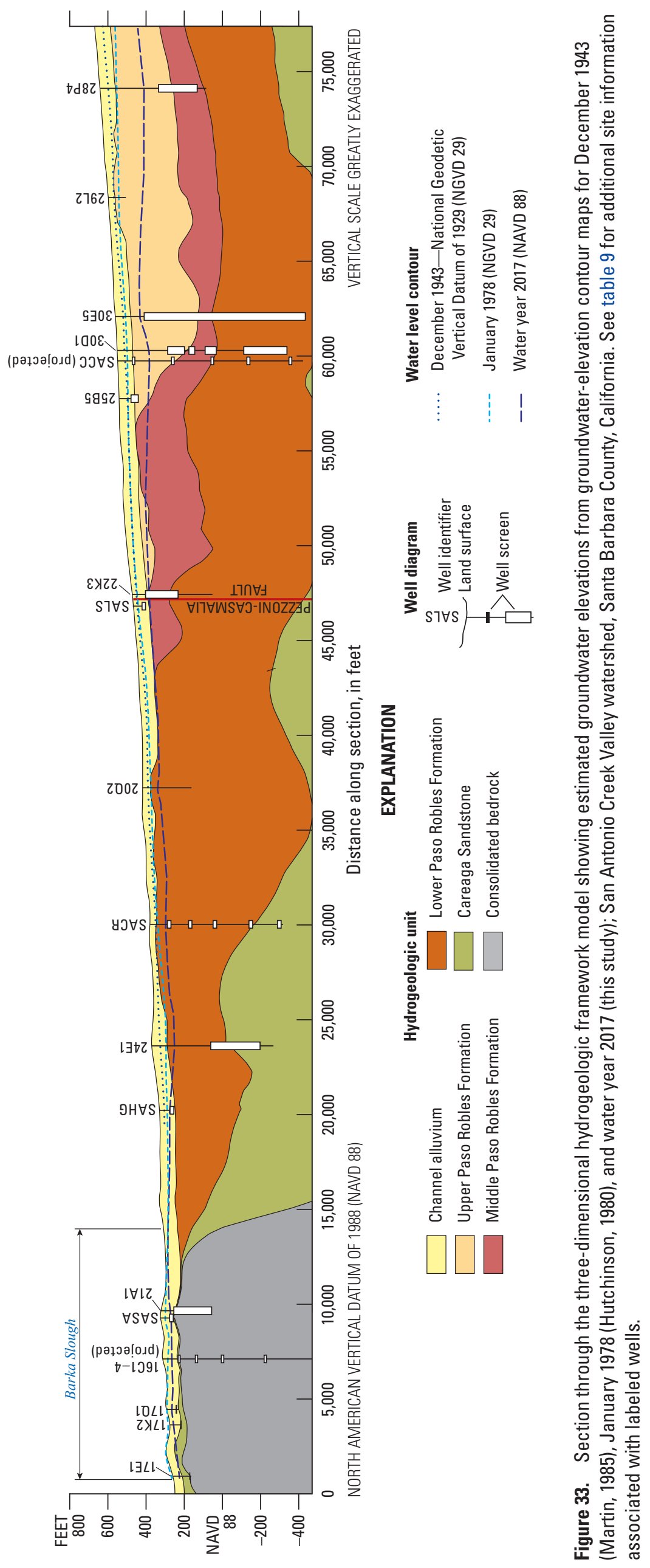




\section{Long-Term Trends in Groundwater Levels}

Long-term groundwater-level data from individual wells with multiple measurements provide insight about how stresses on the aquifer system affect groundwater levels through time. The historical data available in the SACVW document the long-term trends in groundwater levels throughout the valley and were used to evaluate hydrologic differences between the upland areas, the valley floor, and Barka Slough; historical data were also used to compare differences between different hydrogeologic units and the effects of long-term pumping and climate. The SACVW was subdivided into groundwater subareas to better evaluate hydrologic trends within the study area (fig. 34). The subareas were delineated based on the extent of hydrogeologic units and surface-water (topographic) divides. To show trends over the longest possible period, groundwater-level data from adjacent wells of similar construction were combined. Seventeen long-term hydrographs showing groundwater elevations were compiled for wells throughout the SACVW with groundwater-level measurement data collected during calendar years 1948-2018 (figs. 34, 35). Long-term hydrographs are supplemented with short-term groundwater-level measurement data from the USGS multiple- and single-depth, monitoring-well sites; groundwater-level data were available for these sites during calendar year 2016-18 (fig. 19).

\section{Eastern Uplands}

Wells in the eastern uplands of the SACVW are near the main source of natural recharge from precipitation. Groundwater elevations in well 8N/31W-22J1 show generally steady groundwater elevations during the period of record, indicative of the relatively high and usually regular recharge rates balanced by natural discharge at times when pumping in the area is negligible (hydrograph 1; table 9; figs. 34, 35). Groundwater elevations in well 8N/32W-25D1 (hydrograph 2; figs. 34, 35; table 9) show more pronounced variations over the period of record than well $8 \mathrm{~N} / 31 \mathrm{~W}-22 \mathrm{~J} 1$. The declining trend in groundwater elevations in well $8 \mathrm{~N} / 32 \mathrm{~W}-25 \mathrm{D} 1$ are characteristic of other areas in the SACVW and are associated with periods of increased pumping during years with low precipitation (fig. 4). In this area, groundwater elevations generally declined from the beginning of the period of record until about 1990, after which there was an increase in groundwater levels from 1991 to about 2001 that corresponded with a period of $7 \mathrm{yrs}$ with above-average annual precipitation (fig. 4). During the mostly dry climatic period that followed (fig. 3), there was a steady decline in groundwater elevations from 2001 to 2018 (figs. 34, 35).

\section{Eastern Valley}

Groundwater-level variations observed in wells on the valley floor along the entire reach of San Antonio Creek were similar to groundwater-level variations in the eastern uplands, but the amplitudes of these variations were dependent on the hydrogeologic unit in which the wells were perforated and the proximity of the wells to the area of groundwater discharge at Barka Slough. In the eastern valley of the SACVW, channel alluvium is present along San Antonio Creek, and the upper Paso Robles Formation overlies the middle and lower Paso Robles Formations (figs. 17, 33). Wells 8N/32W-28P1 and $8 \mathrm{~N} / 32 \mathrm{~W}-28 \mathrm{P} 3 ;$ 8N/32W-29L2; and 8N/32W-30K2 and $8 \mathrm{~N} / 32 \mathrm{~W}-30 \mathrm{H} 7$ (hydrographs 3, 4, and 5, respectively; figs. 34, 35; table 9) are perforated primarily in the upper Paso Robles Formation (fig. 33). Wells 8N/32W-28P1, 8N/32W-28P3 (hydrograph 3), and 8N/32W-28L2 (hydrograph 4) show groundwater-elevation declines of about 25 to $50 \mathrm{ft}$ between 1984 and 2018, which are associated with expanded development and increased groundwater pumpage during that period. Wells $8 \mathrm{~N} / 32 \mathrm{~W}-30 \mathrm{~K} 2$ and $8 \mathrm{~N} / 32 \mathrm{~W}-30 \mathrm{H} 7$ (hydrograph 5 ) show an overall decline in groundwater elevations of about $25 \mathrm{ft}$ between 1958 and 1985. Wells 8N/32W-28P4; $8 \mathrm{~N} / 32 \mathrm{~W}-30 \mathrm{D} 1$; and $8 \mathrm{~N} / 33 \mathrm{~W}-22 \mathrm{~K} 3$ and $8 \mathrm{~N} / 33 \mathrm{~W}-23 \mathrm{~N} 1$ (hydrographs 6, 7, and 8, respectively; figs. 34, 35; table 9) are perforated primarily in the middle or lower Paso Robles Formation (fig. 33) - these deep wells show a greater decline in groundwater elevations than the shallow wells perforated in the upper Paso Robles Formation; well 8N/32W-30D1, for example, shows a drop of groundwater elevations of about $125 \mathrm{ft}$ from 1984 to 2018 (fig. 35). The smaller groundwater-elevation declines in wells perforated in the upper member of the Paso Robles Formation, compared to wells perforated in the middle and lower members, are the result of proximity of this upper member to natural recharge from precipitation and streamflow in San Antonio Creek. In contrast, the greater groundwater-elevation declines in the middle and lower Paso Robles Formations in this area likely are due to smaller amounts of recharge to these units and a response to pumping under more confined conditions.

Data from wells $8 \mathrm{~N} / 32 \mathrm{~W}-28 \mathrm{P} 1$ and $8 \mathrm{~N} / 32 \mathrm{~W}-28 \mathrm{P} 3$; $8 \mathrm{~N} / 32 \mathrm{~W}-28 \mathrm{~L} 2 ; 8 \mathrm{~N} / 32 \mathrm{~W}-30 \mathrm{~K} 2$ and $8 \mathrm{~N} / 32 \mathrm{~W}-30 \mathrm{H} 7$; $8 \mathrm{~N} / 32 \mathrm{~W}-28 \mathrm{P} 4 ;$ 8N/32W-30D1; and 8N/33W-22K3 and $8 \mathrm{~N} / 33 \mathrm{~W}-23 \mathrm{~N} 1$ show a downward hydraulic gradient between the upper and lower Paso Robles Formations: groundwater elevations range from between about 525 and $600 \mathrm{ft}$ above NAVD 88 in the upper Paso Robles Formation and between about 385 and $520 \mathrm{ft}$ above NAVD 88 in the lower Paso Robles Formation. This downward gradient between these two units is also evident in USGS multiple-depth, monitoring-well site SACC (figs. 19B, 34, 35), where groundwater elevation differences ranged from about 80 to $110 \mathrm{ft}$ between wells in the upper Paso Robles Formation (SACC4 and 5) and the wells in the lower Paso Robles Formation (SACC1, SACC2, and SACC3). Groundwater elevations in well SACC5 were about $60 \mathrm{ft}$ higher than in well SACC4, indicating downward vertical flow within the upper Paso Robles Formation; the higher groundwater levels in SACC5 likely are due to localized recharge from spray-irrigated wastewater effluent due to the proximity of the well-site to the Los Alamos CSD spray fields (fig. 28; K. Barnard, Los Alamos Community Services District, written communication, 2019). 


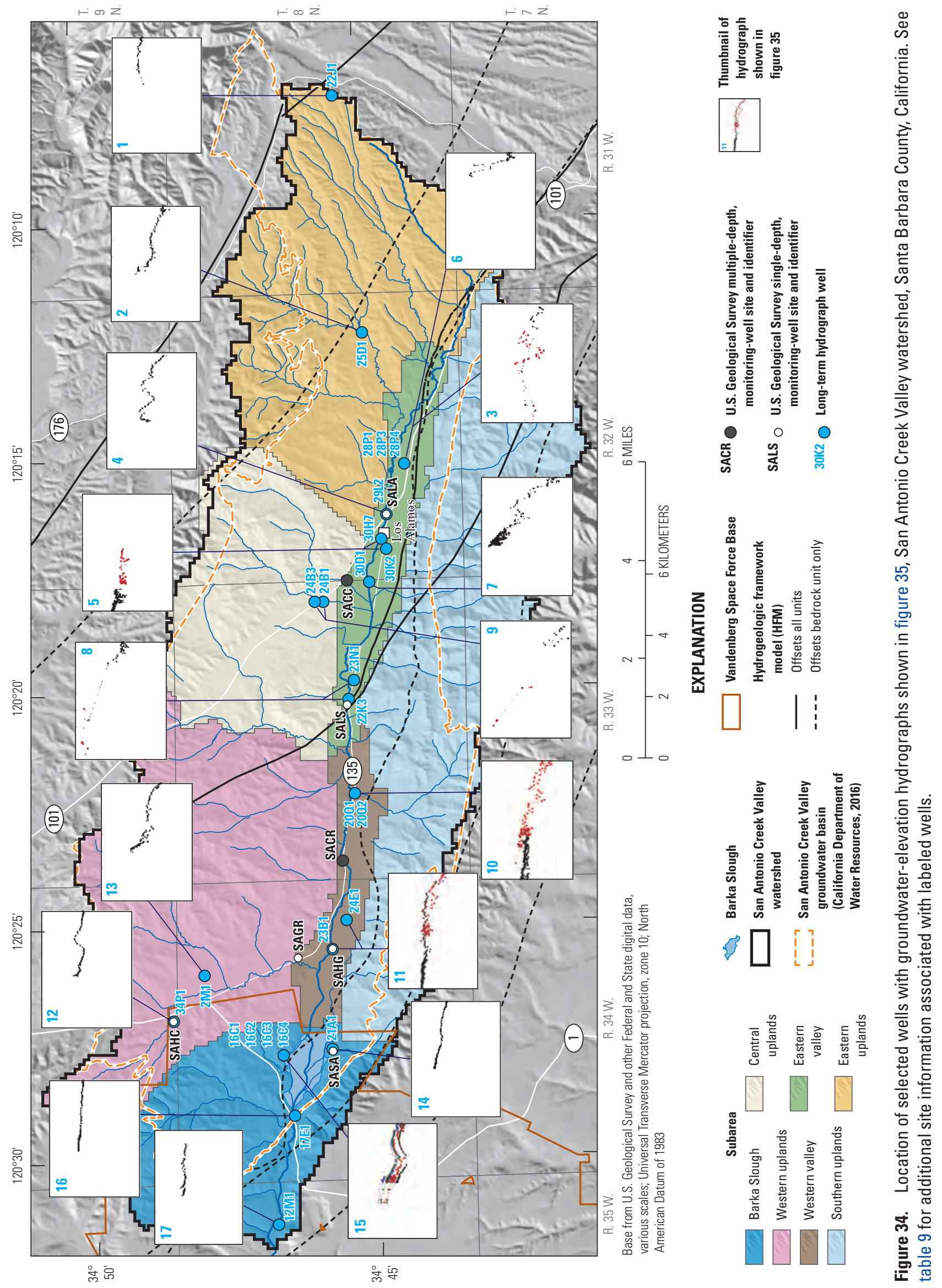


1

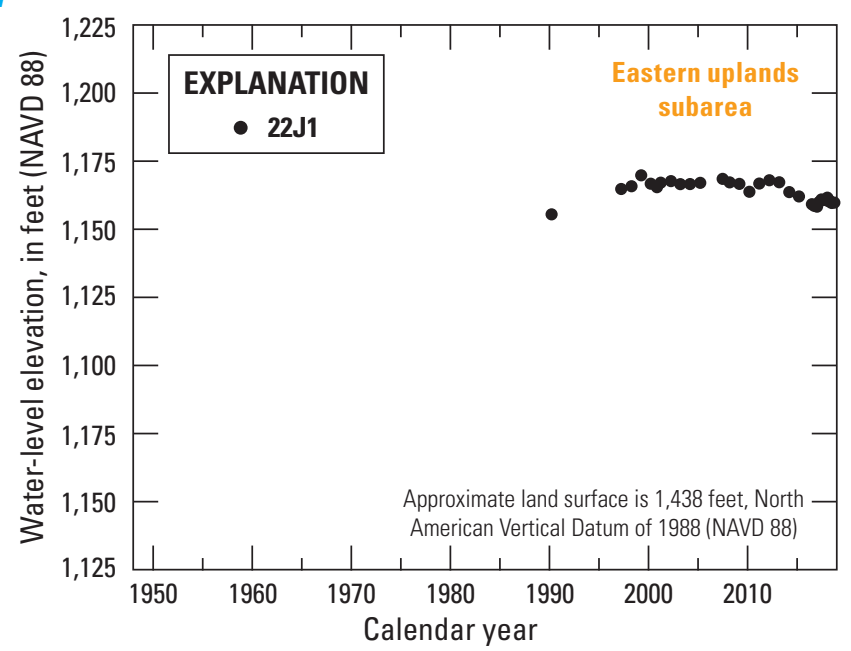

3

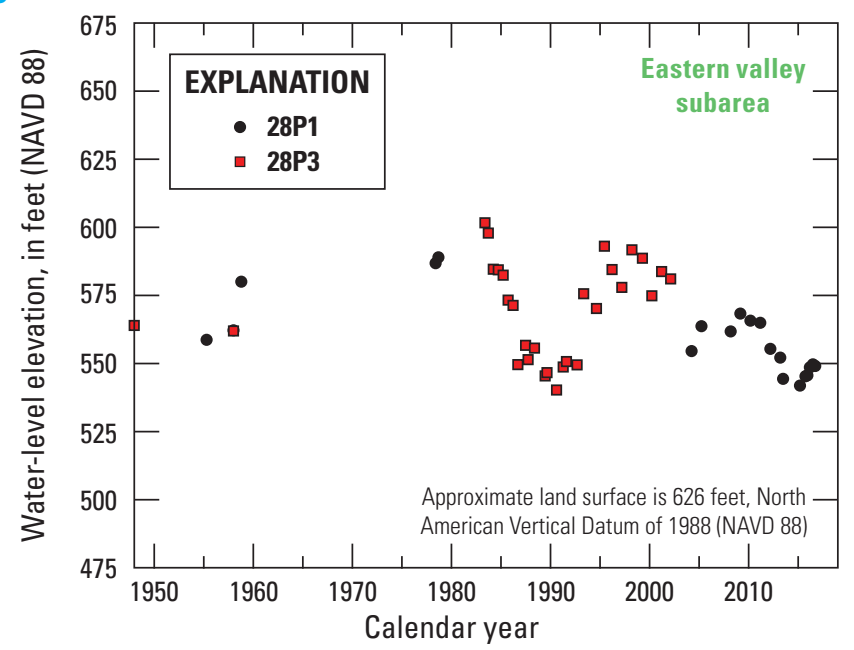

5

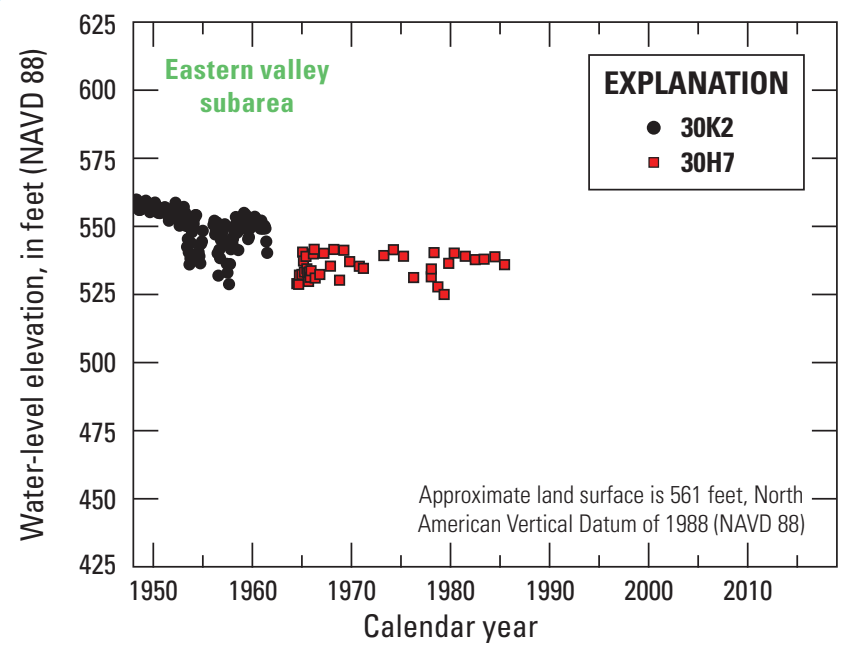

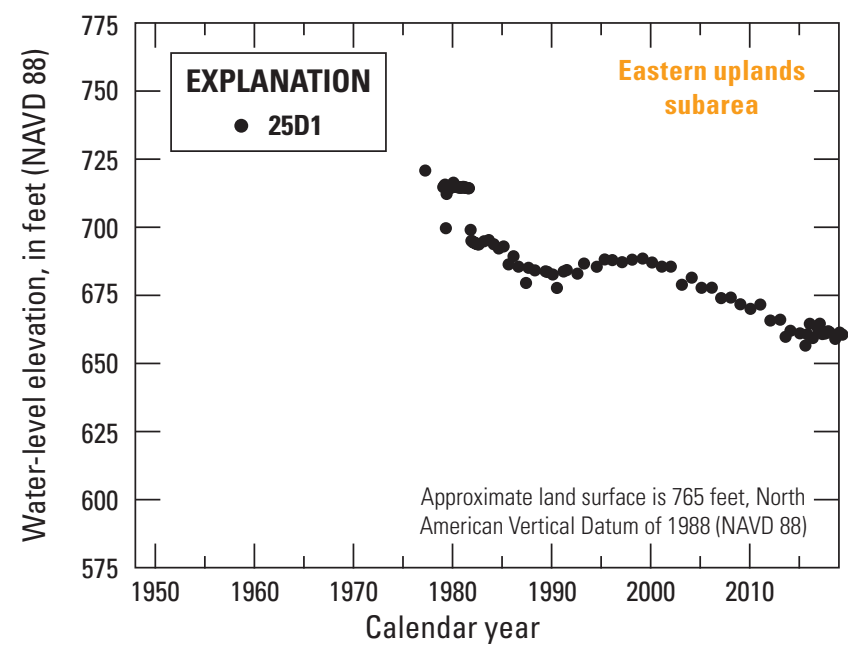

4

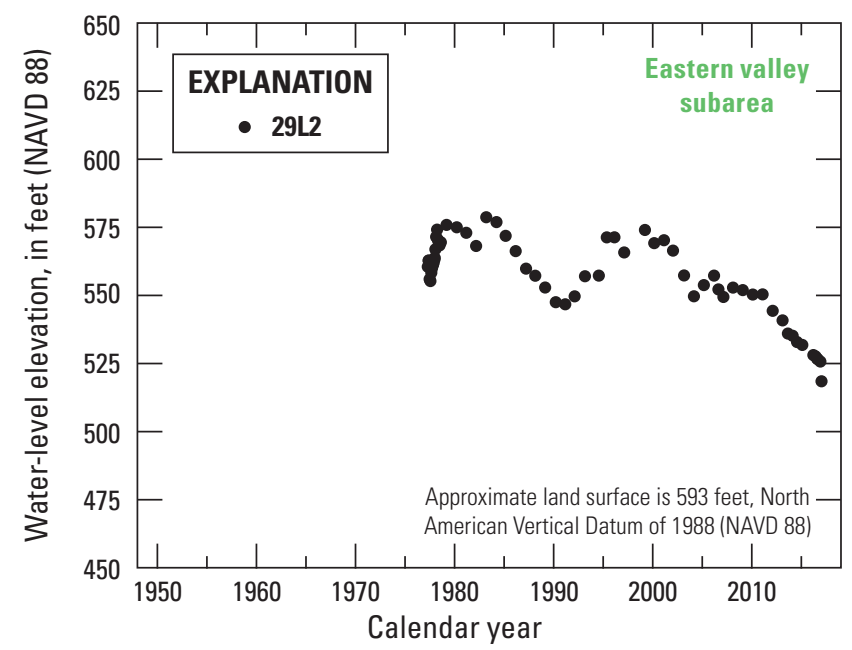

6

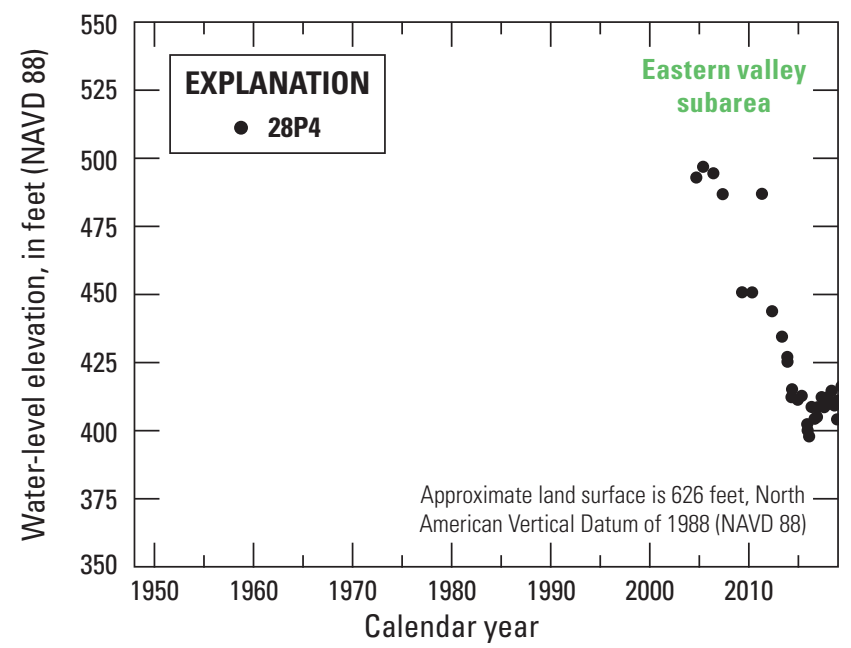

Figure 35. Measured groundwater elevations for selected wells for calendar years 1948-2018, San Antonio Creek Valley watershed, Santa Barbara County, California. See table 9 for additional site information associated with labeled wells. Numbers on each hydrograph panel correspond to the numbers of the inset hydrographs on figure 34. Elevations are in feet above the North American Vertical Datum of 1988 (NAVD 88). See table 9 for additional site information associated with labeled wells. 

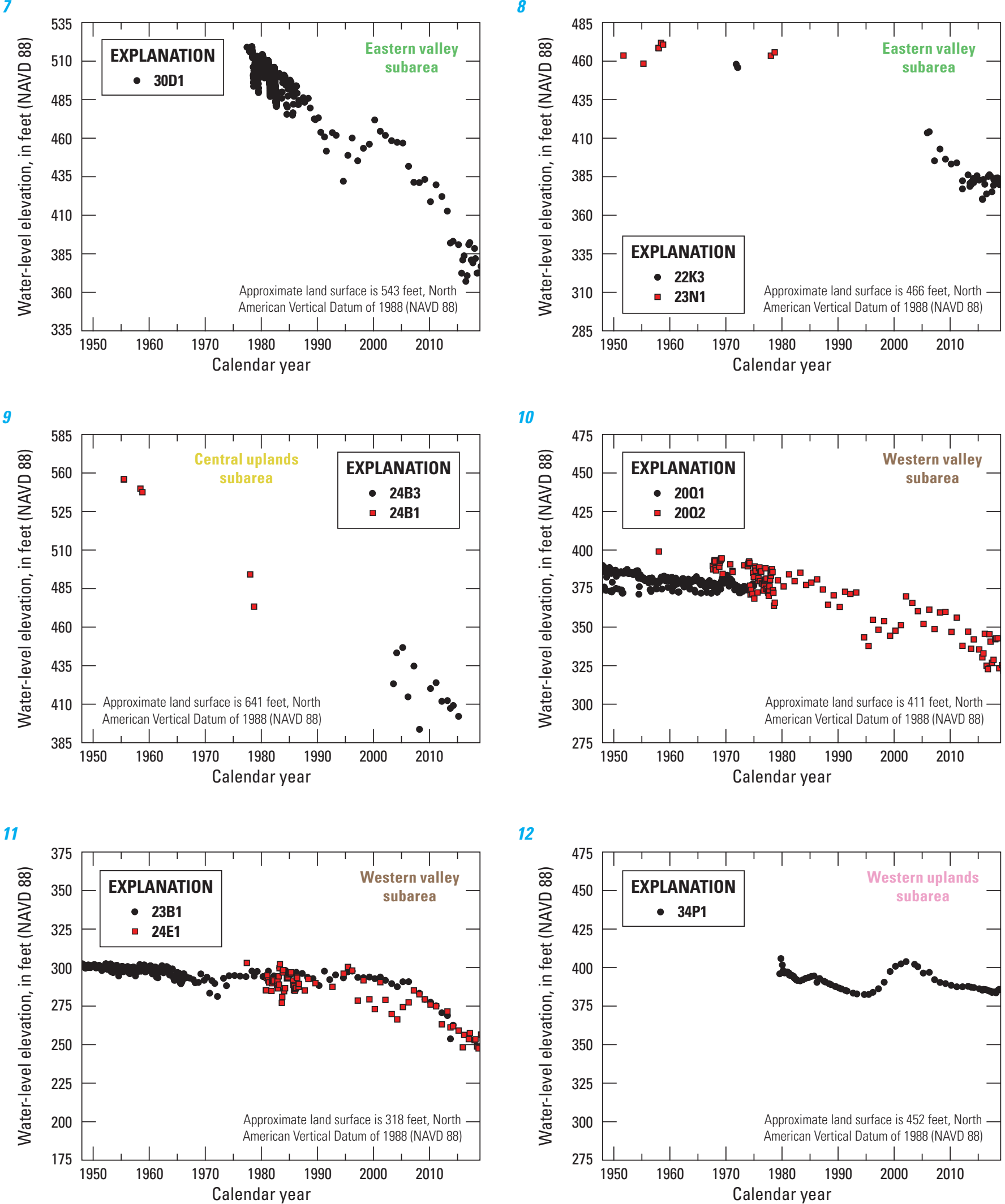

Figure 35.-Continued 
13

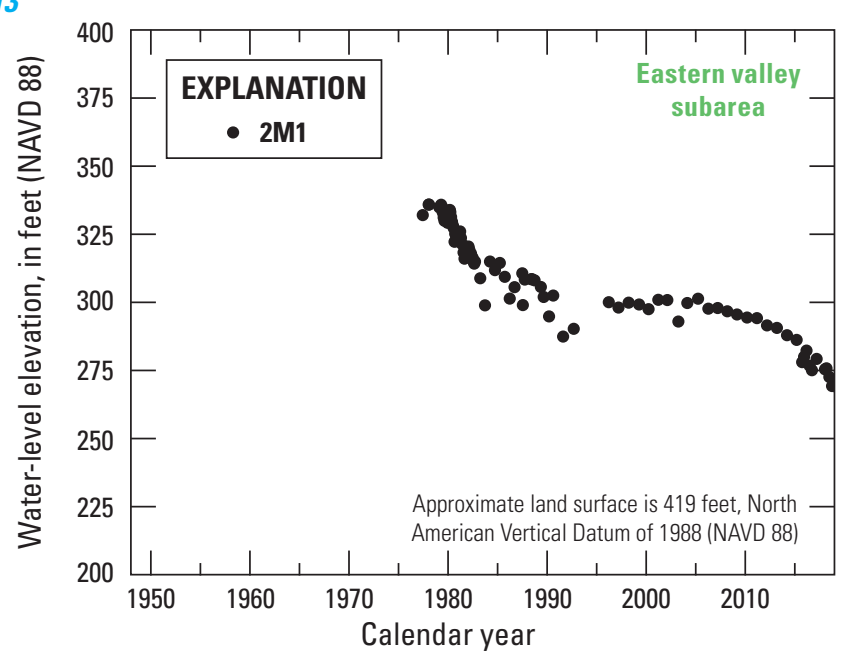

15

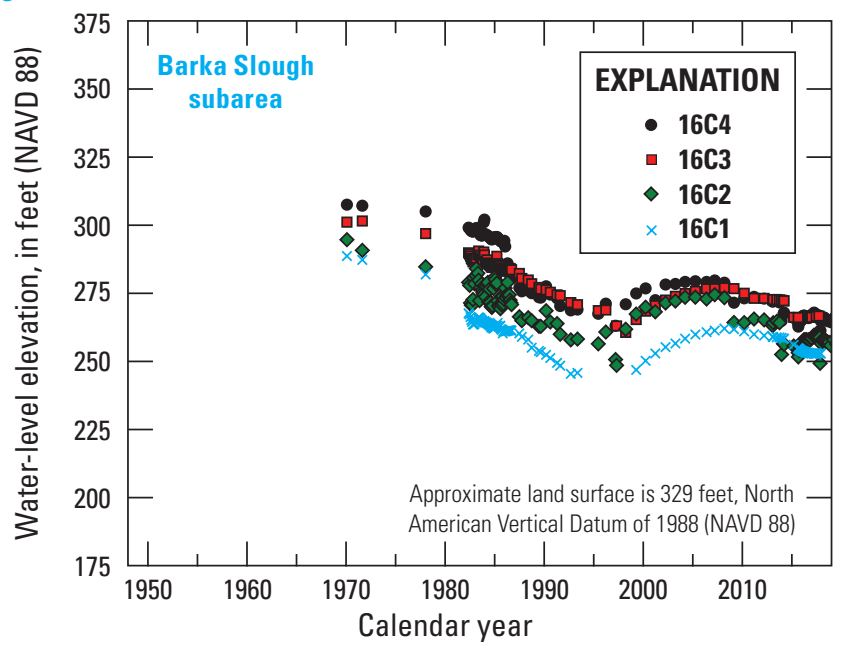

17

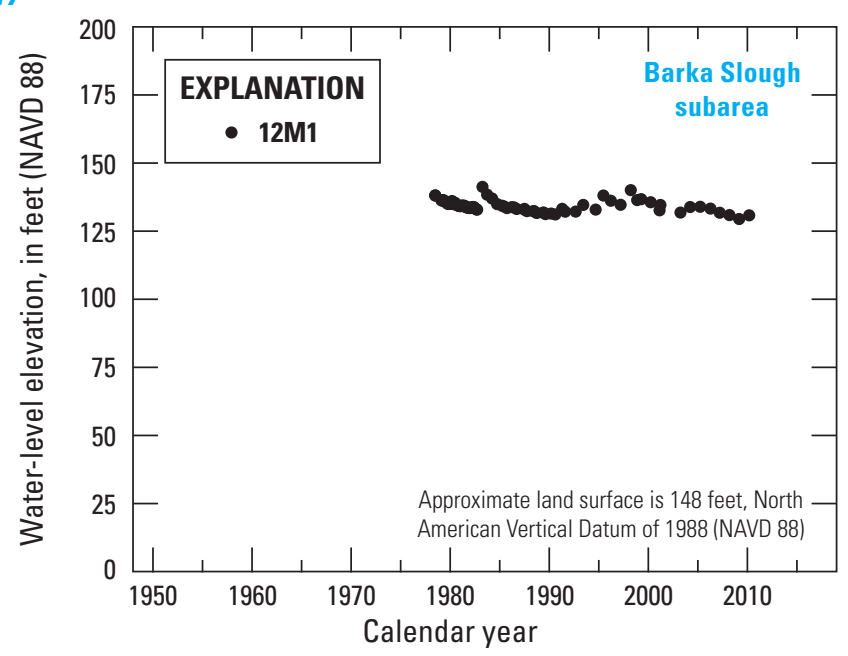

14

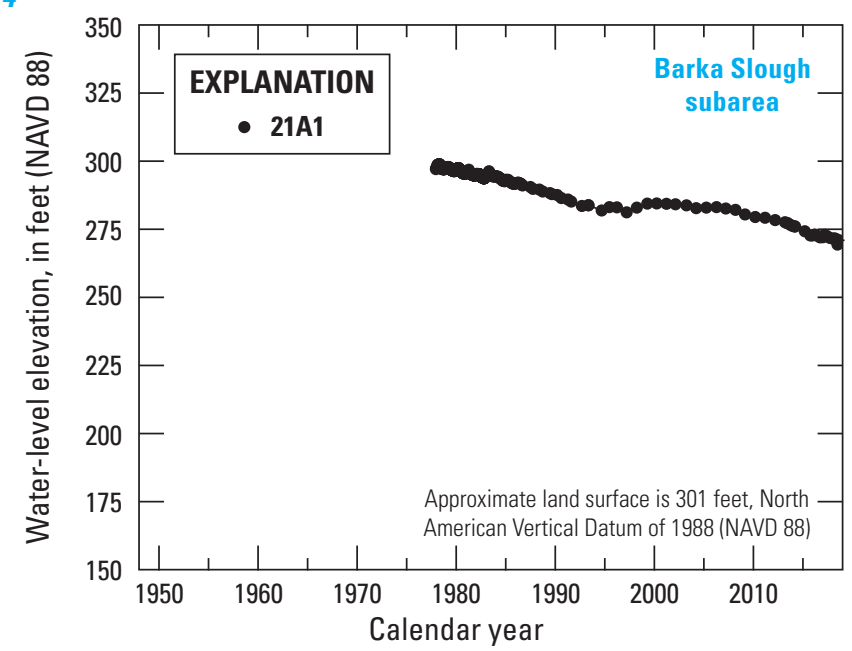

16

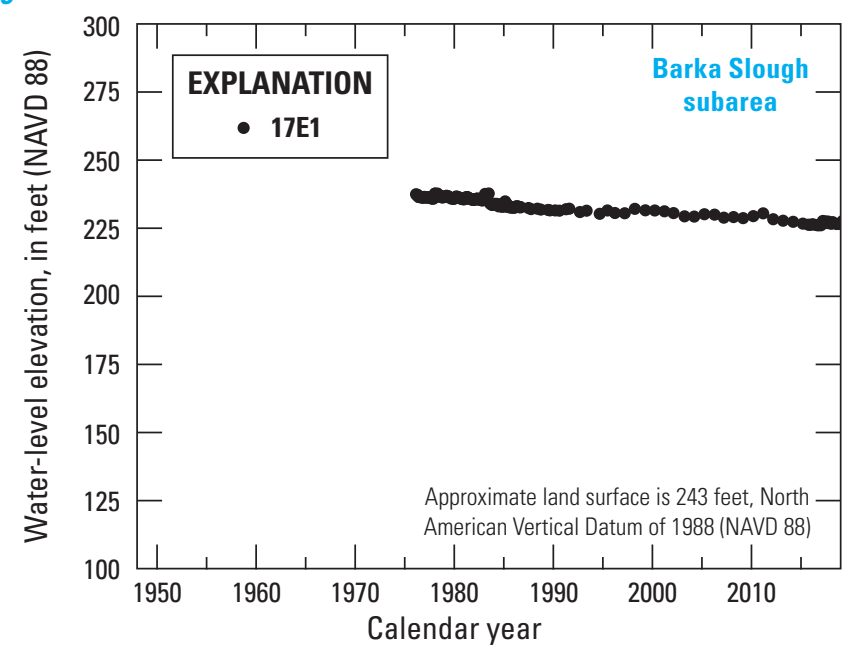

Figure 35.-Continued 


\section{Central Uplands}

Wells $8 \mathrm{~N} / 33 \mathrm{~W}-24 \mathrm{~B} 3$ and $8 \mathrm{~N} / 33 \mathrm{~W}-24 \mathrm{~B} 1$ in the central uplands (hydrograph 9; figs. 34, 35; table 9) are drilled entirely within the upper Paso Robles Formation. Well $8 \mathrm{~N} / 33 \mathrm{~W}-24 \mathrm{~B} 1$ is $582 \mathrm{ft}$ deep; the depth of well $8 \mathrm{~N} / 33 \mathrm{~W}-24 \mathrm{~B} 3$ is unknown, but this well was likely constructed similarly to well $8 \mathrm{~N} / 33 \mathrm{~W}-24 \mathrm{~B} 1$ because of the physical proximity of these wells. These wells show a rate of groundwater-elevation decline similar to deep wells $8 \mathrm{~N} / 32 \mathrm{~W}-28 \mathrm{P} 4,8 \mathrm{~N} / 32 \mathrm{~W}-30 \mathrm{D} 1$, $8 \mathrm{~N} / 33 \mathrm{~W}-24 \mathrm{~B} 3,8 \mathrm{~N} / 33 \mathrm{~W}-24 \mathrm{~B} 1,8 \mathrm{~N} / 33 \mathrm{~W}-22 \mathrm{~K} 3$, and $8 \mathrm{~N} / 33 \mathrm{~W}-23 \mathrm{~N} 1$.

\section{Western Valley}

In the western valley of the SACVW, channel alluvium is present along San Antonio Creek, and the lower Paso Robles Formation and Careaga Sandstone comprise the remainder of the basin-fill sedimentary materials (figs. 17,33); the upper and middle Paso Robles Formation units are absent, pinching out in the center of the SACVW (figs. 17, 33). Wells 8N/33W-20Q1 and 8N/33W-20Q2, and 8N/34W-23B1 and 8N/34W-24E1 (hydrographs 10 and 11, respectively; figs. 34, 35; table 9), are perforated in the lower Paso Robles Formation. Groundwater elevations were relatively steady from 1948to 1984 and declined about $40 \mathrm{ft}$ from 1984 to 2018 (with the most substantial declines occuring since about 2008). Wells in the western valley show less of a decline in groundwater elevations over the period of record than wells in the eastern valley because the western valley receives more groundwater recharge to offset the effects of local groundwater withdrawals. The western valley receives recharge from the infiltration of streamflow along San Antonio Creek and from groundwater that flows from the northern, southern, and eastern parts of the SACVW. An upward gradient is evident in the western valley from USGS multiple-depth, monitoring-well site SACR (figs. 19A, 34), where groundwater-elevations differences ranged from about $25 \mathrm{ft}$ between well SACR1 in the Careaga Sandstone and well SACR2 in the lower Paso Robles Formation, and between about 30 to $50 \mathrm{ft}$ between well SACR2 and wells SACR3, SACR4, and SACR5 within the upper Paso Robles Formation. The upward vertical gradient occurs in this area because groundwater flowing toward the west is forced to the surface by the shallow consolidated bedrock (fig. 33), eventually discharging to land surface at Barka Slough.

The Pezzoni-Casmalia and Los Alamos faults were inferred to transect the SACVW between the western and eastern valley subareas, near well SALS (figs. 33, 34). Groundwater elevations in wells on either side of the faults indicated that these faults did not substantially affect groundwater flow in this part of the SACVW.

\section{Western Uplands}

In the western uplands, the lower Paso Robles Formation and Careaga Sandstone comprise most of the basin-fill sedimentary materials; in the northern parts of this subarea, consolidated bedrock is at, or near, land surface (fig. 17). Well 9N/34W-34P1, in Harris Canyon, is perforated in the Careaga Sandstone (hydrograph 12; table 9; figs. 34, 35). In this well, groundwater elevations gradually declined over time, about $14 \mathrm{ft}$ between 1980 and 2018, with periodic increases in groundwater elevations, such as between 1983 and1985, and 1995 and 2002, associated with years of average or above-average precipitation (fig. 4). Well8N/34W-2M1, east of Harris Canyon, is drilled in the lower Paso Robles Formation and Careaga Sandstone (hydrograph 13; figs. 34, 35; table 9; perforation information was not available for this well). Groundwater elevations declined about $65 \mathrm{ft}$ from 1978 to 2018 but stayed relatively steady during a period of generally above-average precipitation during 1996-2005. The greater groundwater-elevation declines through time and smaller increases during years of above-average precipitation in well 8N/34W-2M1 compared with well 9N/34W-34P1 were likely caused by well $8 \mathrm{~N} / 34 \mathrm{~W}-2 \mathrm{M} 1$ being among the irrigated agricultural fields adjacent to Harris Canyon, whereas well 9N/34W-34P1 is north and west of the agricultural fields (figs. 6, 34).

\section{Barka Slough}

Barka Slough is a perennial marshland at the western end of the SACVW where groundwater is forced to land surface and discharges as base flow into San Antonio Creek. Variations in groundwater levels and base flow at Barka Slough indicate changing groundwater stresses and inputs in the upgradient and upstream areas of the SACVW. Wells $8 \mathrm{~N} / 34 \mathrm{~W}-21 \mathrm{~A} 1$, $8 \mathrm{~N} / 34 \mathrm{~W}-16 \mathrm{C} 1-16 \mathrm{C} 4,8 \mathrm{~N} / 34 \mathrm{~W}-17 \mathrm{E} 1$, and $8 \mathrm{~N} / 35 \mathrm{~W}-12 \mathrm{M} 1$ are adjacent to, or downstream of, Barka Slough (hydrographs $14,15,16$, and 17, respectively; figs. 34,35 ; table 9). Groundwater elevations in well $8 \mathrm{~N} / 34 \mathrm{~W}-21 \mathrm{~A} 1$ declined about $25 \mathrm{ft}$ between 1978 and 2018. The muted groundwater-level variations were likely caused by the well being perforated primarily in consolidated bedrock with limited responses to pumping and recharge.

Wells $8 \mathrm{~N} / 34 \mathrm{~W}-16 \mathrm{C} 1-16 \mathrm{C} 4$ comprise a multiple-depth, monitoring-well site where well $8 \mathrm{~N} / 34 \mathrm{~W}-16 \mathrm{C} 4$ is the deepest (560 ft bls) and well $8 \mathrm{~N} / 34 \mathrm{~W}-16 \mathrm{C} 1$ is the shallowest ( $86 \mathrm{ft} \mathrm{bls}$; figs. 34, 35; table 9). The wells at site $8 \mathrm{~N} / 34 \mathrm{~W}-16 \mathrm{C} 1-16 \mathrm{C} 4$ show an upward vertical gradient with groundwater-elevation differences that ranged between about $25 \mathrm{ft}$ in the early 1970s to about $15 \mathrm{ft}$ in 2017 (hydrograph 15; figs. 34, 35). This upward vertical gradient is due to groundwater discharge near Barka Slough, but the decline in elevation difference through time may indicate that the groundwater head at depth has declined or reduced hydrostatic pressure on the deeper aquifer from groundwater-level declines in upgradient areas. 
Wells $8 \mathrm{~N} / 34 \mathrm{~W}-17 \mathrm{E} 1$ and $8 \mathrm{~N} / 35 \mathrm{~W}-12 \mathrm{M} 1$ are at the western margins of Barka Slough and are perforated in the shallow channel alluvium along San Antonio Creek (hydrographs 16 and 17, respectively; table 9; figs. 33, 34, 35). Groundwater elevations in these wells gradually declined through time, with some variations in groundwater elevations associated with years of higher-than-average precipitation (fig. 4), such as 1983, 1995, and 1998; however, the variations in well $8 \mathrm{~N} / 34 \mathrm{~W}-17 \mathrm{E} 1$ were less pronounced. During the period of record, groundwater elevations were between 237 and $227 \mathrm{ft}$ above NAVD 88 in 8N/34W-17E1 and between 138 and $130 \mathrm{ft}$ NAVD 88 in $8 \mathrm{~N} / 35 \mathrm{~W}-12 \mathrm{M} 1$; the difference in groundwater elevation between these two wells demonstrates the east to west flow of groundwater from the SACVW toward the Pacific Ocean.

\section{Groundwater and Surface-Water Quality}

Water-quality data provide information on the type, source, and age of water in the SACVW. When compared, the water-quality data can be used to evaluate the character and differences in surface-water quality along San Antonio Creek and fingerprint the vertical and spatial distribution of hydrogeochemical facies within the aquifer system, which are related to aquifer mineralogy, recharge source, and groundwater age.

The earliest comprehensive study of groundwater quality in the SACVW was by Muir (1964). Muir (1964) reported that the quality of groundwater throughout most of the SACVW was satisfactory for ordinary use, with total dissolved-solids (TDS) concentrations generally less than about 1,000 parts per million, or milligrams per liter $(\mathrm{mg} / \mathrm{L})$; water with TDS concentrations less than $1,000 \mathrm{mg} / \mathrm{L}$ is defined as fresh water (Robinove and others, 1958), but groundwater near Barka Slough had high TDS concentrations of more than $3,000 \mathrm{mg} / \mathrm{L}$. West of Barka Slough, the quality of surface water and groundwater was poor because of seepage of saline water from the shallow underlying geologic units that comprise the consolidated bedrock unit and possibly the Careaga Sandstone (Muir, 1964). Muir (1964) also reported that water quality in the SACVW did not change appreciably between 1927 and 1958. The California Department of Water Resources (1971) did not document any substantial changes in water quality since the publication of findings by Muir (1964). Hutchinson (1980) reported an average TDS concentration in groundwater east of Barka Slough of $710 \mathrm{mg} / \mathrm{L}$ and noted that salinity, or dissolved salts mainly of sodium and chloride, was increasing in the agricultural parts of the basin.

Mathany and others (2010), Burton and others (2013), and Burton and Belitz (2013) collected groundwater-quality samples in the SACVW as part of the USGS Priority Basin Project of the Groundwater Ambient Monitoring and Assessment (GAMA) program. The GAMA program provides a statistically unbiased, spatially distributed assessment of the quality of untreated groundwater within primary aquifer systems on a regional scale throughout California. Fifty-five wells were sampled in 2008 in parts of Santa Barbara and San Luis Obispo Counties, 10 of which were in the SACVW (Burton and others, 2013). Groundwater-quality samples from wells within and near the Orcutt Oil Field (fig. 36) were sampled as part of the USGS California Oil, Gas, and Groundwater program (COGG). The COGG program is a cooperative effort between the USGS and the California State Water Resources Control Board (https://webapps.usgs.gov/cogg/; accessed September 2019) to address concerns about groundwater quality in regions of oil and gas development activities. A total of 16 wells were sampled in 2017-18 as part of the COGG program, 10 of which were in the SACVW (R. Anders, U.S. Geological Survey, written commun., 2020; McCarlson and others, 2021).

\section{Method of Sample Collection and Analysis}

Water-quality samples were collected at 42 groundwater sites and 3 surface-water sites in 2017-18 (table 9; U.S. Geological Survey, 2021). Sample collection and processing followed the methods described in the USGS National Field Manual (U.S. Geological Survey, variously dated). Groundwater samples were analyzed in the field for specific conductance, $\mathrm{pH}$, temperature, and alkalinity (USGS National Water-Quality Laboratory [NWQL] field schedule; Barbash and Bell, 2002; Wilde, variously dated) and analyzed in the laboratory for $\mathrm{pH}$, specific conductance, and alkalinity (NWQL schedule 1948; Fishman and Friedman, 1989; Wilde, variously dated), major and minor ions and selected trace elements (NWQL schedule 1948; Fishman and Friedman, 1989; Fishman, 1993; Garbarino, 1999; Garbarino and others, 2005), nutrients (NWQL schedule 2755; Fishman, 1993; Patton and Kryskalla, 2003, 2011), stable isotopes of water (NWQL schedule 1142; Epstein and Mayeda, 1953; Coplen and others, 1991; Coplen, 1994; Révész and Coplen, 2008a, b), and activities of radioactive isotopes of tritium (NWQL laboratory code 1565; Thatcher and others, 1977) and carbon (NWQL schedule 2255; Vogel and others, 1987; Donahue and others, 1990; Gagnon and Jones, 1993; Schneider and others, 1994; National Ocean Sciences Accelerator Mass Spectrometry Facility, 2018).

Groundwater samples for major and minor ions, trace elements, alkalinity, and TDS analyses included raw groundwater and filtered groundwater (U.S. Geological Survey, variously dated). Filtered samples were filtered using a 0.45-micrometer capsule filter. The filtered sample was preserved with nitric acid. Major ions, selected trace elements, and nutrient samples were analyzed at the NWQL or by laboratories contracted by the NWQL. Stable isotopes were analyzed by the USGS Reston Stable Isotope Laboratory in Reston, Virginia. Activities of radioactive isotopes of tritium were analyzed by the USGS Stable Isotope and 

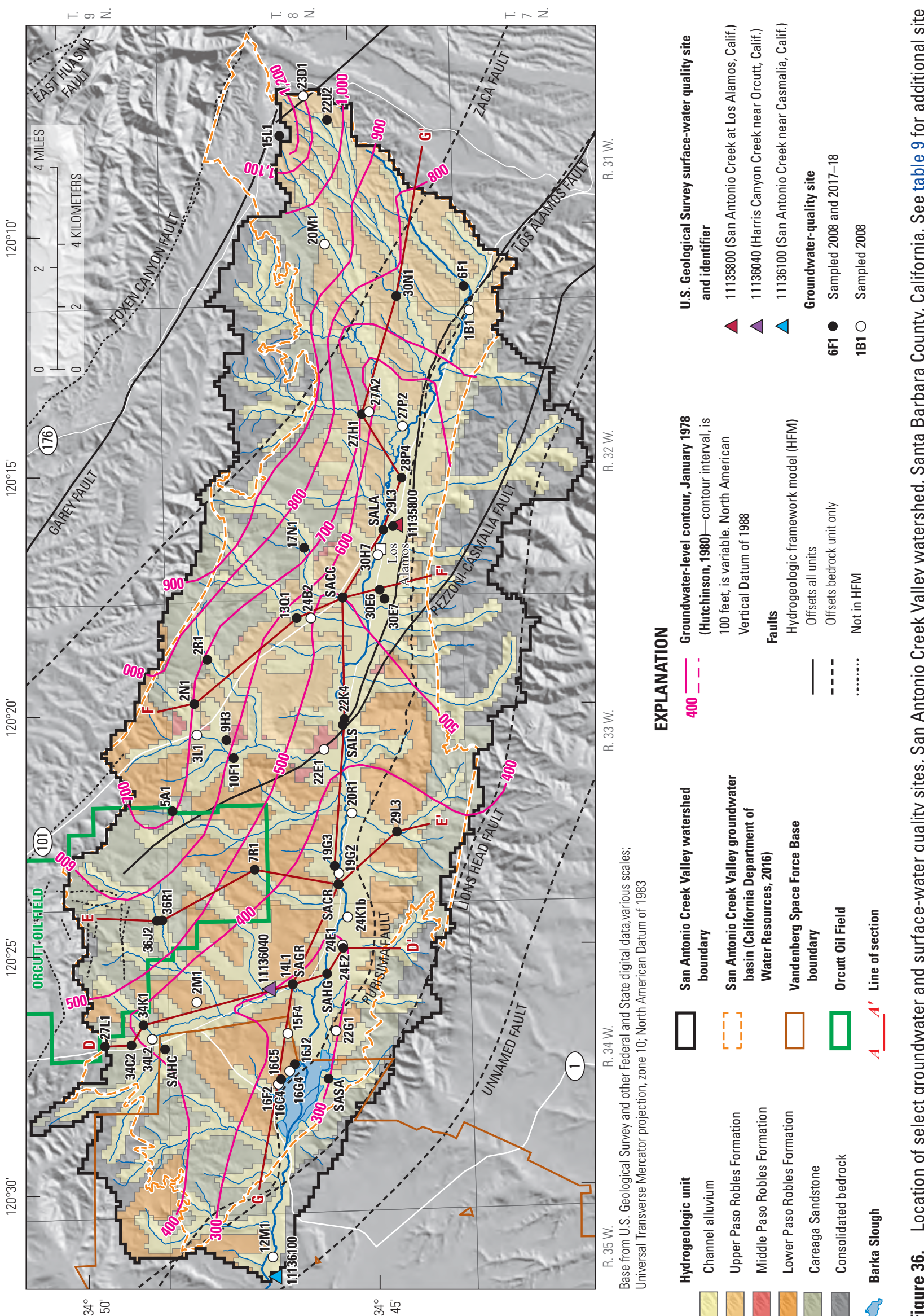

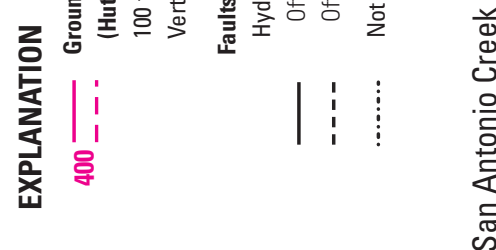

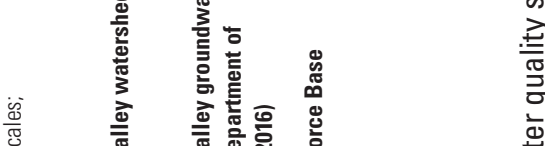

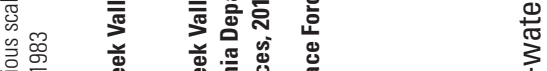

证

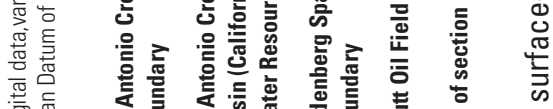

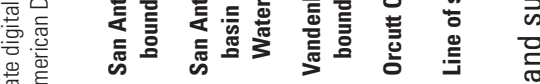

空辛

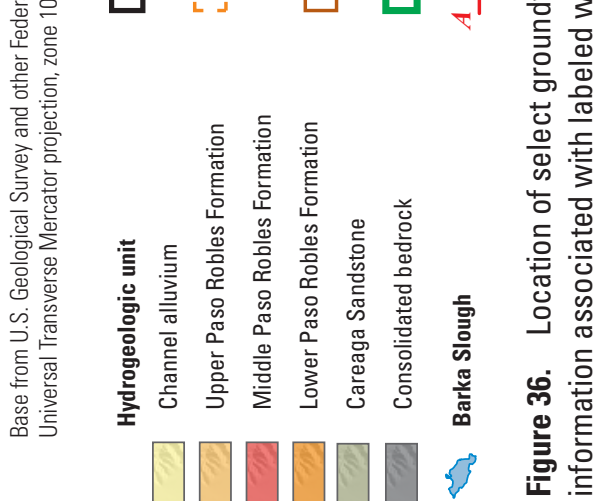


Tritium Laboratory in Menlo Park, California. Activities of radioactive isotopes of tritium carbon were analyzed by Woods Hole Oceanographic Institution, National Ocean Sciences Accelerator Mass Spectrometry Facility in Woods Hole, Massachusetts.

The TDS concentration in water was primarily determined from the weight of the dry residue remaining after evaporation of an aliquot of the water sample at 180 degrees Celsius (referred to as residue on evaporation, ROE; U.S. Geological Survey, 2021). In instances where ROE data were unavailable, the TDS concentrations in water were determined using major ion concentration data. If ROE data were unavailable, the summed dissolved-solids concentration was used, but these values did not include adjustments of bicarbonate to carbonate ions that are commonly made to make the computation comparable to the ROE value for the same sample. Thus, these summed concentrations can be much lower than the ROE. The concentration of TDS was used to characterize groundwater salinity. In this study, definitions of groundwater salinity were as defined by Robinove and others (1958): TDS less than $1,000 \mathrm{mg} / \mathrm{L}$ is fresh water, TDS between 1,000 and $3,000 \mathrm{mg} / \mathrm{L}$ is slightly saline water, TDS between 3,000 and $10,000 \mathrm{mg} / \mathrm{L}$ is moderately saline water, TDS between 10,000 and $35,000 \mathrm{mg} / \mathrm{L}$ is highly saline water, and TDS greater than $35,000 \mathrm{mg} / \mathrm{L}$ is briny water.

\section{Chemical Composition of Surface-Water and Groundwater}

The general water-quality characteristics of surface water and groundwater in the SACVW were evaluated using several methods and are described in the following sections. A variety of water-quality diagrams can be used to show the spatial and vertical variability of water quality among sites.

\section{Surface-Water Quality}

The quality of surface water in the SACVW is controlled by the water quality of storm runoff, groundwater discharged as base flow, and runoff from agricultural irrigation; thus, surface-water quality varied greatly depending on location within the SACVW and the time of year the samples were collected. Water-quality samples were collected from three surface-water sites in the SACVW during 2017-18: San Antonio Creek at 11135800 (hereafter referred to as the Los Alamos streamgage), Harris Creek at surface-water quality site 11136040 (hereafter referred to as the Harris Canyon streamgage), and San Antonio Creek at surface-water quality site 11136100 (hereafter referred to as the Casmalia streamgage; fig. 36; table 9; U.S. Geological Survey, 2021).

The surface-water quality varied depending on the where the samples were taken. The Los Alamos streamgage is in a sandy channel in San Antonio Creek in the eastern valley, and the Harris Canyon streamgage is in a narrow sandy creek that drains from the Casmalia Hills into San Antonio Creek in the western uplands; streamflow is intermittent at each of these sites. The Casmalia streamgage is situated at the westernmost end of the SACVW, west of Barka Slough. Samples were collected from all three sites during the winter, after a storm, and from the Harris Canyon and Casmalia streamgages during the fall, at the end of the dry season (Santa Barbara County, 2019). A sample was not collected from the Los Alamos streamgage during the fall because the creek was dry. The Harris Canyon streamgage sample collected during the winter was not used for this evaluation because the sample appeared to have been compromised with excess sediment as a result of poor sample collection technique or incomplete filtration during sampling (U.S. Geological Survey, 2021).

\section{General Water-Quality Composition}

Surface-water quality varied depending on time of year the sample was collected and the location of the sample within the SACVW (U.S. Geological Survey, 2021). In general, TDS concentrations and major ion concentrations were lower at the Los Alamos and Harris Canyon streamgages than at the downstream Casmalia streamgage (figs. 37, 38; U.S. Geological Survey, 2021). Calcium-sulfate-type water was identified using surface-water quality data collected at the Los Alamos streamgage during the winter in 2017, with a TDS concentrations of $280 \mathrm{mg} / \mathrm{L}$ and major ion concentrations for calcium, chloride, nitrate, and sulfate of 29.5, 24.9, 1.33, and $106 \mathrm{mg} / \mathrm{L}$, respectively (fig. 38D; U.S. Geological Survey, 2021). Cation-chloride-type water was identified using surface-water quality data collected at the Harris Canyon streamgage during fall 2017, with a TDS concentration of $1,080 \mathrm{mg} / \mathrm{L}$ and major ion concentrations of calcium, chloride, nitrate, and sulfate of 144, 208, 35.1, and $204 \mathrm{mg} / \mathrm{L}$, respectively (fig. 38A; U.S. Geological Survey, 2021). Calcium-sulfate-type water was identified using surface-water quality data at the Casmalia streamgage during the winter in 2017, with a TDS concentration of $1,370 \mathrm{mg} / \mathrm{L}$ and major ion concentrations of calcium, chloride, nitrate, and sulfate of $191,196,26.6$, and $526 \mathrm{mg} / \mathrm{L}$, respectively (fig. $38 D$; U.S. Geological Survey, 2021). Sodium-chloride-type water was identified using surface-water quality data collected at the Casmalia streamgage during fall 2017, with a TDS concentration of $1,580 \mathrm{mg} / \mathrm{L}$ and major ion concentrations of calcium, chloride, nitrate, sulfate, and sodium of 142 , $375,6.77,316$, and $347 \mathrm{mg} / \mathrm{L}$, respectively (fig. 38D; U.S. Geological Survey, 2021). The Casmalia streamgage had TDS concentrations that were higher than the Los Alamos and Harris Canyon streamgages during winter and fall 2017. The winter 2017 sample collected at the Los Alamos streamgage likely represented water quality associated with storm runoff, and the samples collected at the Harris Canyon and Casmalia streamgages likely represented a mixture of storm runoff and base flow. 


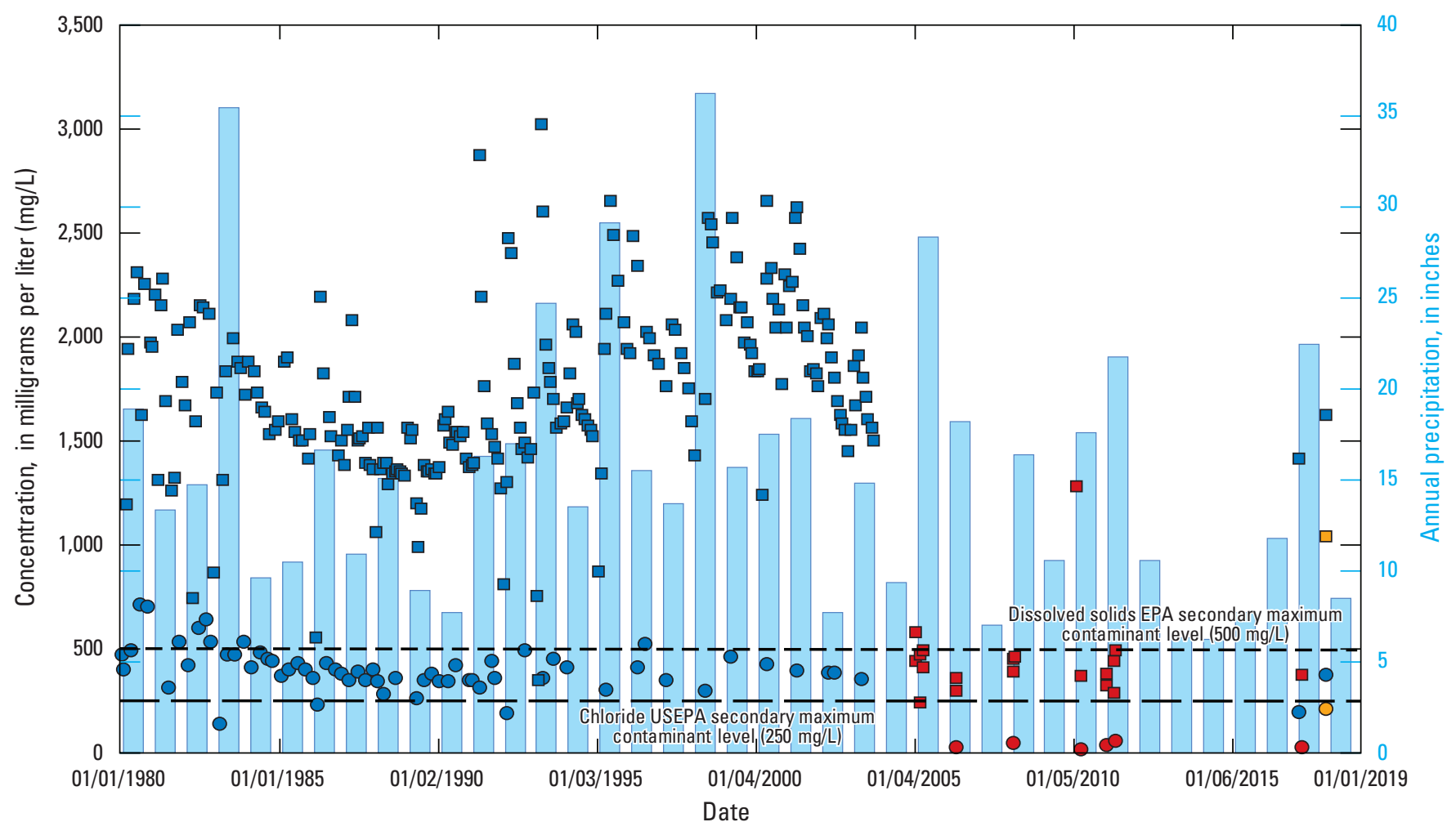

EXPLANATION

Total dissolved solids

11136000 (San Antonio Creek at Harris, Calif.)

- 11135800 (San Antonio Creek at Los Alamos, Calif.)

- 11136100 (San Antonio Creek near Casmalia, Calif.)
Chloride

- 11136000 (San Antonio Creek at Harris, Calif.)

- 11135800 (San Antonio Creek at Los Alamos, Calif.)

- 11136100 (San Antonio Creek near Casmalia, Calif.)
Annual precipitation

Figure 37. Annual precipitation and concentrations of total dissolved solids and chloride at U.S. Geological Survey stations 11136040 , 11135800, and 11136100 (U.S. Geological Survey, 2021), San Antonio Creek Valley watershed, Santa Barbara County, California. U.S. Environmental Protection Agency (EPA) secondary maximum contaminant levels from U.S. Environmental Protection Agency (2017a).

\section{Long-Term Trends}

As discussed in the previous section, water quality at the three surface-water quality sites varied greatly depending on location within the SACVW and the time of year the samples were collected. To evaluate the long-term trends in water quality, concentrations of TDS and chloride at the Los Alamos and Casmalia streamgages were compared for samples collected during 1980-2018 (fig. 37). The Harris Canyon streamgage and water-quality site was only sampled in 2017 and was therefore not included in this discussion. TDS and chloride concentrations at the Los Alamos streamgage and water-quality site (11135800) remained mostly unchanged over the period of record, and almost all samples had concentrations below the U.S. Environmental Protection Agency (EPA) recommended Secondary Maximum Contaminant Level (SMCL) of $500 \mathrm{mg} / \mathrm{L}$ for TDS and
$250 \mathrm{mg} / \mathrm{L}$ for chloride (U.S. Environmental Protection Agency, 2017a) - only two samples had TDS concentrations above the SMCL.

The TDS and chloride concentrations at the Casmalia streamgage varied with respect to the amount of annual precipitation and, except for four samples, had concentrations above EPA recommended SMCLs for both constituents (fig. 37; U.S. Environmental Protection Agency, 2017a; U.S. Geological Survey, 2021). Decreased concentrations of TDS and chloride at the Casmalia streamgage during 1980-90 and 2001-03 coincided with general decreases in annual precipitation; increased concentrations of TDS and chloride during 1991-2000 coincided with a general increase in annual precipitation. The relation between increased precipitation and high concentrations of TDS and chloride may be attributed to an increase in the amount of runoff of soil additives used in agriculture during wetter years and a corresponding decrease in runoff during drier years. 


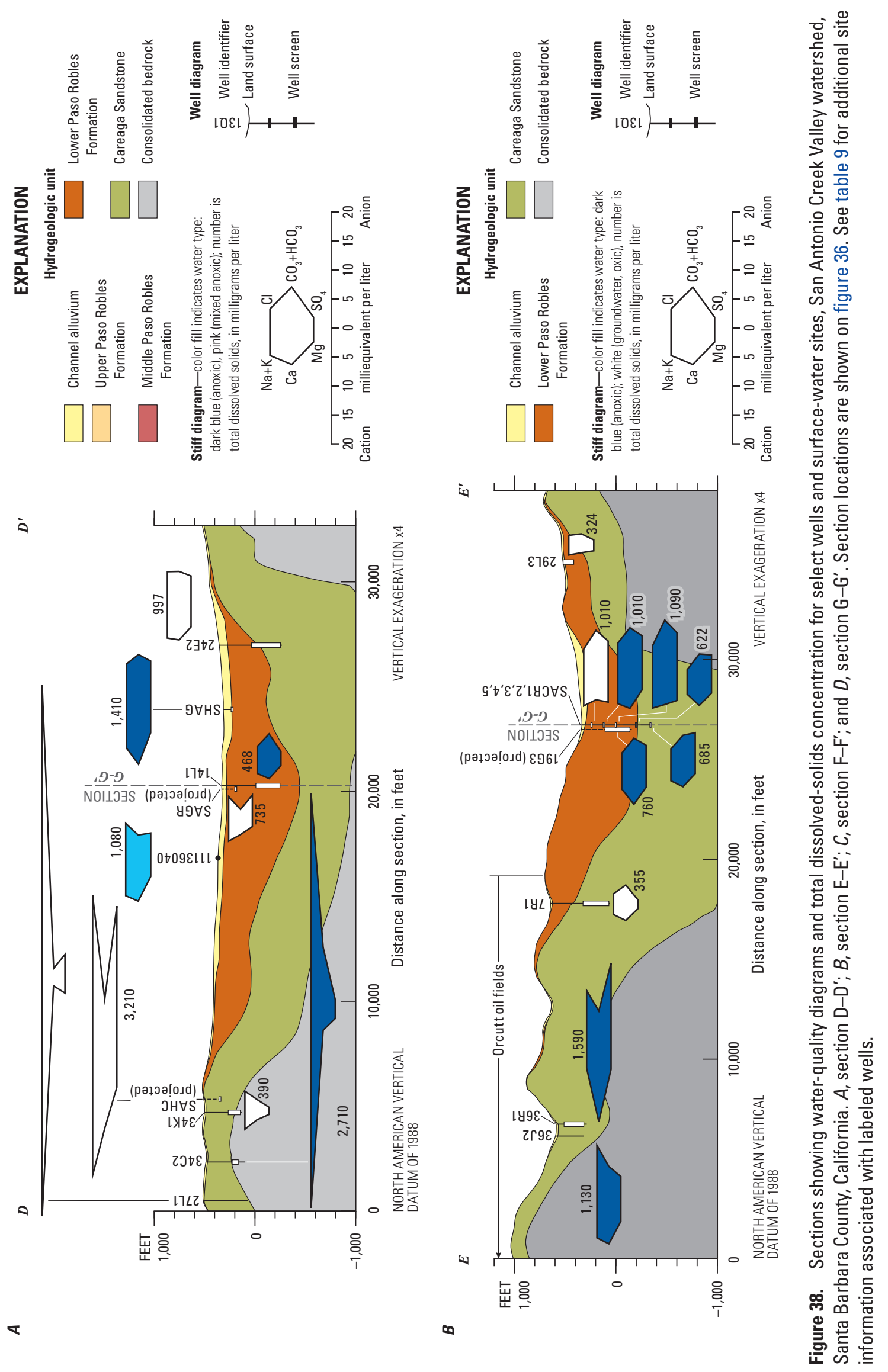



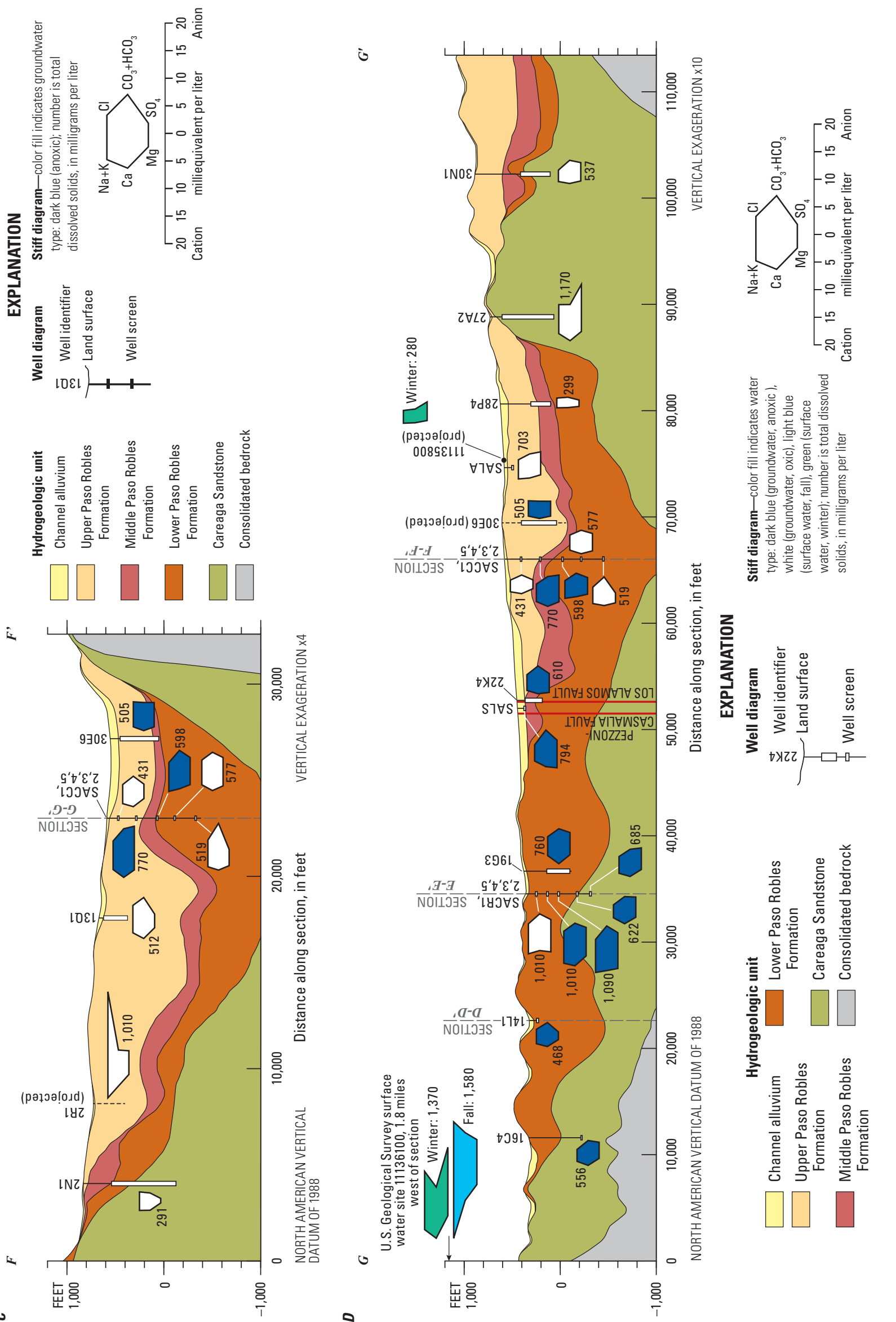

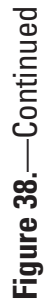




\section{Groundwater Quality}

Groundwater quality in the SACVW is controlled by the chemistry of the recharge water and various geochemical reactions occurring in the subsurface, including dissolution, precipitation of minerals in the subsurface, mixing with agricultural irrigation-return flow, and solute concentration resulting from evaporation. Groundwater quality and source and age of groundwater were characterized for the SACVW using analyses for selected physical properties, inorganic constituents, and stable and radioactive isotopes. Each chemical and isotopic tracer preserves some aspect of the hydrologic history of the groundwater, including the chemical composition of the groundwater (major ions, minor ions, and TDS), reduction/oxidation (redox) conditions of groundwater, time-since-recharge (tritium and carbon-14), and the source of water (stable isotopes of oxygen and hydrogen). This section describes (1) the areal, depth-dependent, and temporal variations in groundwater quality, including groundwater-quality constituents of concern, and (2) the recharge source and age of groundwater.

\section{General Water-Quality Composition}

There are many ways to evaluate the chemical composition of surface water and groundwater. The chemical composition of groundwater in the SACVW from the corresponding hydrogeologic units and with depth is illustrated using water-quality diagrams using a method suggested by Stiff (1951; fig. 38). TDS and major ion concentrations are presented in milliequivalent units per liter (meq/L) diagrammatically on four sections through the SACVW from the HFM. Each section (locations shown on fig. 36) shows selected surface-water sites and groundwater wells that were sampled, and the depth of the perforated interval from which samples were analyzed for each well. The left side of each Stiff diagram shows the major cations, with sodium plus potassium $(\mathrm{Na}+\mathrm{K})$ at the top, calcium $(\mathrm{Ca})$ in the middle, and magnesium $(\mathrm{Mg})$ at the bottom. The right side of the diagram shows major anions, with chloride $(\mathrm{Cl})$ at the top, carbonate plus bicarbonate $\left(\mathrm{CO}_{3}+\mathrm{HCO}_{3}\right)$ in the middle, and sulfate $\left(\mathrm{SO}_{4}\right)$ on the bottom. The width and shape of the diagrams differ depending on the concentrations of major ions; water that contains higher concentrations of major ions has a wider diagram than the diagram for water with lower concentrations. Water samples with similar major-ion concentrations can be easily identified by their similarly shaped water-quality diagrams.

Groundwater in wells in the SACVW had TDS concentrations ranging from between about $300 \mathrm{mg} / \mathrm{L}$ to more than 3,200 mg/L (fig. 38; U.S. Geological Survey, 2021). Groundwater samples with lower TDS concentrations (about $500-800 \mathrm{mg} / \mathrm{L}$ ) generally were from wells near sources of natural recharge in the eastern uplands in the upper Paso Robles Formation and Careaga Sandstone, in the eastern valley in the basin-fill hydrogeologic units, and in deep wells in the western valley and Barka Slough in the Careaga Sandstone (figs. 36, 38D). Groundwater samples with higher TDS concentrations (about $800-1,500 \mathrm{mg} / \mathrm{L}$ ) were from shallow wells in the western uplands and the western valley floor near areas of deep groundwater discharge in the lower Paso Robles Formation. Groundwater samples with the highest TDS concentrations (about 1,100-3,200 mg/L) were from wells in the western uplands near the Orcutt Oil Field in the Careaga Sandstone and consolidated bedrock (figs. 36, $38 A, 38 B)$.

Three groundwater types were observed in the SACVW and were classified based on the major ion composition of groundwater: (1) calcium-bicarbonate groundwater present throughout most of the valley sourced from recharge areas in the eastern uplands, (2) calcium/sodium-chloride-type to calcium-sulfate-type groundwater in the western uplands that may be mixed with water from oil-bearing formations or older, saline groundwater and (or) thermogenic hydrocarbon gases from oil-bearing formations (R. Anders, U.S. Geological Survey, written commun., 2020; McCarlson and others, 2021), and (3) sodium- or chloride-rich calcium-bicarbonate groundwater in the western uplands and western valley that is a mixture of recharged water from the eastern uplands and saline groundwater from the shallow underlying geologic units that comprise consolidated bedrock and possibly the Careaga Sandstone.

Groundwater samples from most wells throughout the SACVW are characterized as calcium-bicarbonate-type water. Wells in the eastern part of the SACVW (such as wells $8 \mathrm{~N} / 31 \mathrm{~W}-30 \mathrm{~N} 1,8 \mathrm{~N} / 32 \mathrm{~W}-28 \mathrm{P} 4$, SACC1-5, and 8N/33W-22K4; fig. 38D), and select wells in the western part of the SACVW (such as wells SACR1, SACR2, 8N/34W-14L1, 8N/33W-07R1, and 8N/34W-16C4), had groundwater quality with the chemical composition of natural recharge and TDS concentrations that ranged from about 300 to $800 \mathrm{mg} / \mathrm{L}$ (figs. $38 B$, 38D; U.S. Geological Survey, 2021). The chemical composition of groundwater for most other wells in the SACVW was similar, indicating that most groundwater was recharged from natural sources (infiltration of streamflow and precipitation), although water in some wells had slightly higher concentrations of sodium or sulfate. Wells with groundwater recharged from natural sources were perforated in all basin-fill hydrogeologic units (fig. 38). The Pezzoni-Casmalia and Los Alamos faults, which were inferred to transect the SACVW between the western and eastern areas of the valley floor (figs. 36, 38), did not markedly divide the major ion concentrations in groundwater in the SACVW.

Four wells in the SACVW $(9 \mathrm{~N} / 34 \mathrm{~W}-27 \mathrm{~L} 1$, 9N/34W-34C2, 9N/34W-36J2, and 9N/34W-36R1; figs. 36, $38 \mathrm{~A}, 38 \mathrm{~B}$ ) were identified as possibly containing groundwater mixed with water from oil-bearing formations or older, saline groundwater (R. Anders, U.S. Geological Survey, written commun., 2020; McCarlson and others, 2021). Wells 9N/34W-34C2 and 9N/34W-27L1 were adjacent to the Orcutt Oil Field (fig. 36), were perforated in the Careaga Sandstone and consolidated bedrock, and had groundwater enriched in 
sodium and chloride compared to groundwater throughout most of the valley. Wells 9N/34W-34C2 and 9N/34W-27L1 had TDS concentrations of 2,710 and $7,920 \mathrm{mg} / \mathrm{L}$, respectively (fig. 38A); however, the sample from well 9N/34W-27L1 may have been contaminated (U.S. Geological Survey, 2021). These wells appeared to contain groundwater mixed with water from oil-bearing formations based on a combination of salinity tracers, ammonium, dissolved organic carbon, enriched $\delta^{13} \mathrm{C}$ values, and the detection of dissolved petroleum hydrocarbons (R. Anders, U.S. Geological Survey, written commun., 2020; McCarlson and others, 2021). Wells 9N/34W-36J2 and 9N/34W-36R1, located within the Orcutt Oil Field boundary (fig. 36), had groundwater enriched in calcium, chloride, and sulfate, compared to groundwater throughout most of the valley, and had TDS concentrations of 1,130 and $1,590 \mathrm{mg} / \mathrm{L}$, respectively (fig. 38B; U.S. Geological Survey, 2021). Groundwater in these wells contained a combination of methanogenic indicators and trace amounts of hydrocarbon gases (propane and isobutane) that indicated the presence of thermogenic hydrocarbon gases from oil-bearing formations mixed with microbial methane. Elevated concentrations of TDS and bromine/chlorine and iodine/ chlorine ratios may be consistent with either the presence of small amounts of water from oil-bearing formations or saline groundwater (R. Anders, U.S. Geological Survey, written commun., 2020; McCarlson and others, 2021).

Groundwater mixed with saline water was evident in nine wells: wells SAHC, SAGR, SAHG, and 8N/34W-24E2 (fig. 38A), well 8N/33W-2R1 (fig. 38C), and wells 8N/32W-27A2, SACR3, SACR4 and SACR5 (fig. 38D). All nine wells were perforated at shallow depths in all basin-fill hydrogeologic units (top perforation intervals less than 350 feet bls) and were drilled in the eastern or western uplands along tributary streams $(8 \mathrm{~N} / 32 \mathrm{~W}-27 \mathrm{~A} 2,8 \mathrm{~N} / 33 \mathrm{~W}-2 \mathrm{R} 1$, SAGR, SAHC) or on the western valley floor near San Antonio Creek (SACR3, SACR4, SACR5, SAHG, and 8N/34W-24E2).

Groundwater samples in wells 8N/32W-27A2, 8N/33W-2R1, SAHC, and SAGR, had major ion concentrations that were depleted in carbonate and bicarbonate and enriched in sodium, chloride, or sulfate compared to most water in the SACVW (fig. 38; U.S. Geological Survey, 2021). Groundwater samples in wells SACR3, SACR4, SACR5, SAHG, and 8N/34W-24E2 had similar chemical compositions to groundwater throughout most of the SACVW but had slightly higher TDS concentrations; the water quality of deep wells SACR1 and SACR2 were similar to water throughout most of the valley, and these wells had lower TDS concentrations than water from shallow wells SACR3, SACR4, and SACR5 (fig. 38D; U.S. Geological Survey, 2021).

The exact source of increased salinity and differences in major ion concentrations in the nine wells mentioned above cannot be conclusively identified. Although discharge of deep groundwater is known to occur in the western part of the SACVW near Barka Slough, discharge of deep groundwater was likely not the source of increased salinity in wells at the western end of the valley. TDS concentrations of groundwater in deep wells SACR1 and SACR2 (685 and $622 \mathrm{mg} / \mathrm{L}$, respectively; fig. 38D; U.S. Geological Survey, 2021) were almost half of the TDS concentrations in shallow wells SACR3, SACR4, and SACR5 (1,010-1,090 mg/L; figs. 38B, $D$; U.S. Geological Survey, 2021). Some inferences can be made from available water-quality data, such as stable isotope data presented later in this report. Analysis of chloride-to-trace element ratios may provide additional insight into sources of saline water. The long-term patterns in selected constituents are discussed in detail in the next section to help identify potential sources of the high-salinity water.

\section{Long-term Changes}

Selected wells with long-term water-quality data were used to evaluate changes over time in the SACVW. Long-term changes in groundwater quality were evaluated using analyses of selected constituents from four individual wells $(8 \mathrm{~N} / 31 \mathrm{~W}-15 \mathrm{~L} 1,8 \mathrm{~N} / 32 \mathrm{~W}-29 \mathrm{~L} 3,8 \mathrm{~N} / 32 \mathrm{~W}-30 \mathrm{E} 6$, and $8 \mathrm{~N} / 34 \mathrm{~W}-16 \mathrm{~F} 2)$ and two sets of paired wells (8N/33W-19G2 and SACR5, and 8N/34W-24E1 and 8N/34W-24E2). The wells are shown on figure 39 , and additional information on each well is listed in table 9. Each individual well or set of paired wells had data collected since 1980 and included at least one sample collected between 2008 and 2018 (fig. 39; U.S. Geological Survey, 2021). Paired wells were proximal to each other and were perforated at similar depths. Evaluated constituents consisted of (1) TDS and chloride (fig. 39A), (2) nitrate (measured as nitrogen; fig. 39B), and (3) calcium and magnesium (fig. 39C). U.S. Environmental Protection Agency SMCLs for TDS and chloride are shown on figure $39 \mathrm{~A}$ (500 and $250 \mathrm{mg} / \mathrm{L}$, respectively; U.S. Environmental Protection Agency, 2017a), and the EPA maximum contaminant level (MCL) for nitrate (measured as nitrogen) is shown on figure $39 B(10 \mathrm{mg} / \mathrm{L}$; U.S. Environmental Protection Agency, 2017b). The EPA does not list SMCLs or MCLs for concentrations of calcium or magnesium (fig. 39C).

Chloride often is chosen as a single-constituent indicator of general water quality because it is geochemically nonreactive and highly soluble; as a result, variations in chloride concentrations are generally attributed to mixing with water from different sources (Hem, 1992). Because chloride is a conservative ion and a major component of TDS, the two constituents are usually strongly correlated. Nitrate (measured as nitrogen), calcium, and magnesium are essential elements for plant and animals (Hem, 1992) and are commonly associated with agricultural activities.

Total dissolved-solid concentrations increased since 1980 in water from all wells except for well 8N/31W-15L1 and paired wells 8N/33W-19G2 and SACR5 (fig. 39A). TDS concentrations slightly decreased in well $8 \mathrm{~N} / 31 \mathrm{~W}-15 \mathrm{~L} 1$. In paired wells 8N/33W-19G2 and SACR5, TDS concentrations decreased during 1980-87 then remained steady after 1987 (fig. 39; U.S. Geological Survey, 2021). Chloride concentrations generally increased in water samples from all wells when TDS concentrations increased except for paired 


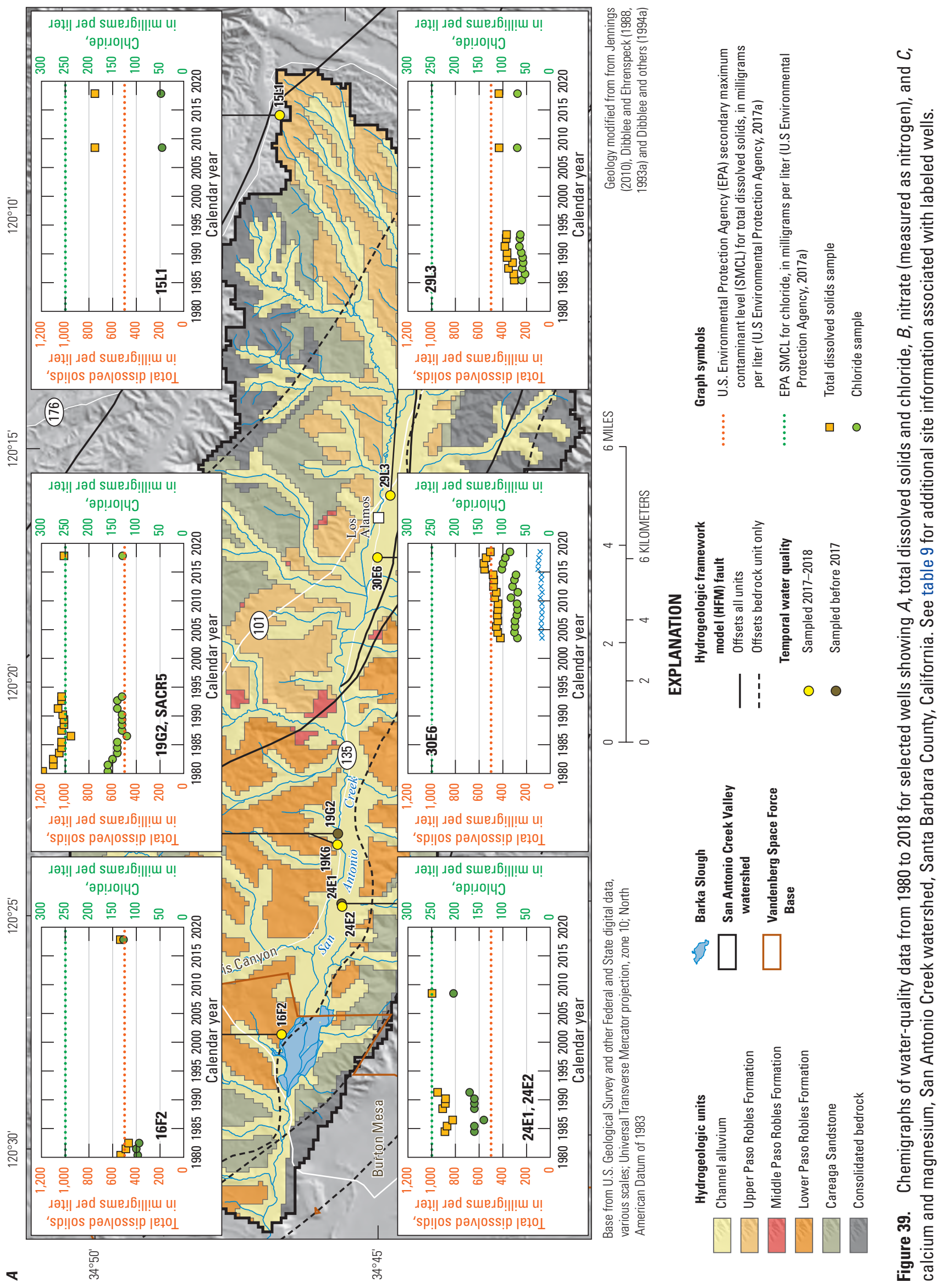



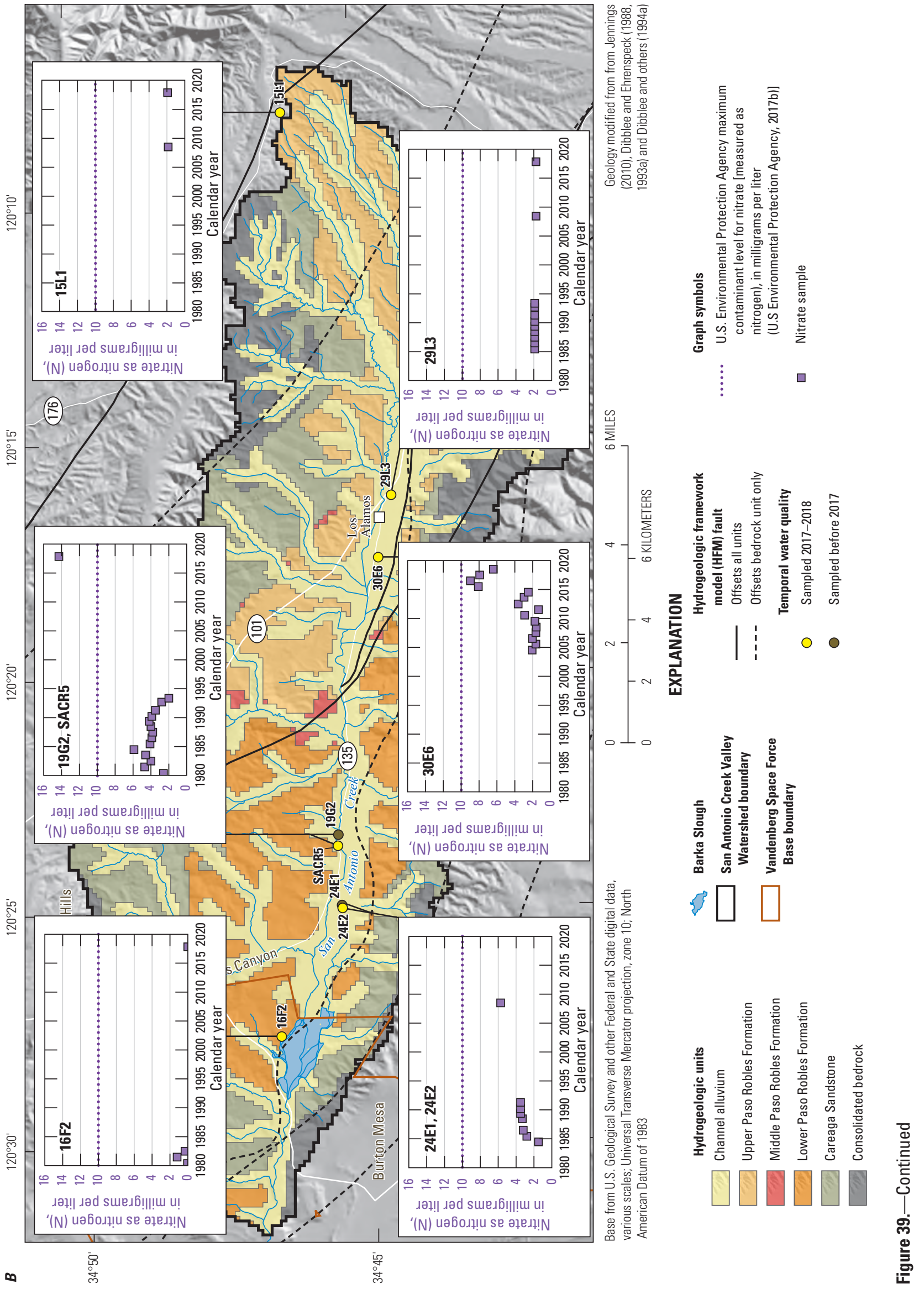


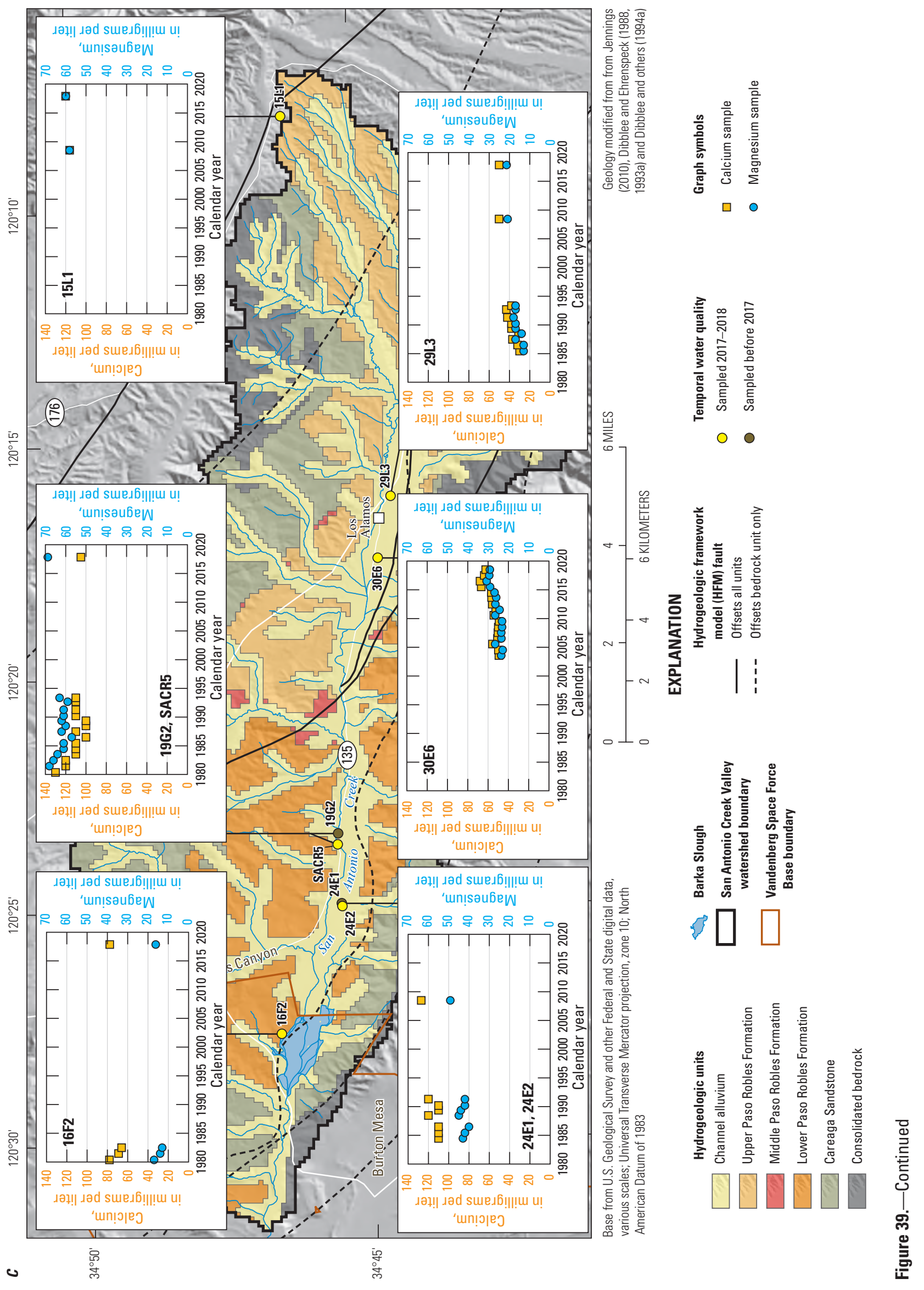


wells $8 \mathrm{~N} / 33 \mathrm{~W}-19 \mathrm{G} 2$ and SACR5, which had a relatively unchanged concentration of chloride after 1987 (fig. 34A). The decrease in TDS and chloride concentrations in water samples from paired wells $8 \mathrm{~N} / 33 \mathrm{~W}-19 \mathrm{G} 2$ and SACR5 indicated some mixing with water that had lower TDS concentrations.

Nitrate (measured as nitrogen [as N]) concentrations increased since 1980 in well 8N/32W-30E6 and paired wells 8N/33W-19G2 and SACR5 and 8N/34W-24E1 and 8N/34W-24E2 (fig. 39B; U.S. Geological Survey, 2021). Although only one water sample from well 8N/33W-19G2 showed an increase in nitrate (as N), the sample was presumed to be representative unless future samples show otherwise. The variation in concentrations of nitrate (as $\mathrm{N}$ ) in water samples from well 8N/32W-30E6 and paired wells $8 \mathrm{~N} / 33 \mathrm{~W}-19 \mathrm{G} 2$, and SACR 5 may be related to the timing of recharge from storms and runoff from agricultural irrigation. The increase in nitrate concentrations through time may indicate that groundwater from these wells has been influenced by the expansion of agriculture in the SACVW (figs. 6, 7; U.S. Geological Survey, 2021) and the associated increase in agricultural-irrigation-return water. Calcium and magnesium concentrations generally increased since 1980 in all wells (fig. 39C; U.S. Geological Survey, 2021). The increase in calcium and magnesium across the SACVW may possibly correspond to the expansion of agriculture (figs. 6,7) and the likely use of calcium- and magnesium-based fertilizers and soil additives, which are commonly used for agricultural purposes.

\section{Reduction/0xidation Conditions of Groundwater}

The reduction/oxidation (redox) condition of groundwater affects the concentration, transport, and fate of many anthropogenic and natural groundwater contaminants and is often related to groundwater age. The redox condition of a groundwater sample can be defined in several ways (for example, Lindberg and Runnels, 1984); in this study the redox condition is defined by the dominant type of redox reaction occurring in the sample, as inferred from water-quality data (Jurgens and others, 2009). The redox conditions of groundwater can be a strong indicator of contaminants that might be present at elevated concentrations. For example, concentrations of arsenic and manganese are more likely to be present at elevated concentrations in anoxic groundwater, and concentrations of uranium, selenium, and nitrate are more likely to be present at elevated concentrations in oxic groundwater (U.S. Geological Survey, 2020).

Knowing the redox condition of groundwater helps in predicting what contaminants and constituents might be present in groundwater at levels of concern for human health. One of the most common redox processes in groundwater is the microbially driven reduction of nitrate to nitrogen gas, which occurs only under anoxic conditions - conversion of nitrate to nitrogen gas is the primary way that nitrate is attenuated in the subsurface (McMahon and Chapelle, 2008; Chapelle and others, 2009).
Aquifer systems are complex environments that may be oxygenated near the surface (oxic conditions) and reduced at depth (anoxic conditions), with redox conditions changing in response to recharge, discharge, and other factors. During oxic conditions, nitrogen can be oxidized from ammonia to nitrate; during anoxic conditions, denitrification can occur, and nitrate (as N) can be reduced to nitrogen gas. Redox conditions in groundwater, and the occurrence of denitrification, can help identify areas of discharge of deep groundwater.

Groundwater age is often related to redox conditions. In general, recently recharged groundwater is likely to be oxic, and older groundwater is more likely to be anoxic. In most aquifers, older groundwater is more likely than younger groundwater to be anoxic because there has been more time for chemical reactions to consume dissolved oxygen. However, redox conditions can vary across short distances because of small-scale variability in aquifers, such as the irregular distribution of organic-rich layers (U.S. Geological Survey, 2020).

Redox conditions of groundwater samples in the SACVW were assigned using a method by Jurgens and others (2009) that identifies redox processes in groundwater. This method assigns the predominant redox process to samples as suggested by McMahon and Chapelle (2008). The assignment of redox conditions is based on concentrations of dissolved oxygen $\left(\mathrm{O}_{2}\right)$, nitrate $\left(\mathrm{NO}_{3}^{-}\right)$, manganese $\left(\mathrm{Mn}^{2+}\right)$, iron $\left(\mathrm{Fe}^{2+}\right)$, sulfate $\left(\mathrm{SO}_{4}{ }^{2-}\right)$, and sulfide (sum of dihydrogen sulfide [aqueous $\left.\mathrm{H}_{2} \mathrm{~S}\right]$, hydrogen sulfide [HS ${ }^{-}$, and sulfide $\left[\mathrm{S}_{2}^{-}\right.$; Jurgens and others, 2009). Redox conditions were assigned to groundwater samples from 45 wells with water-quality data collected during calendar years 2008-18 and to samples for which nitrate, manganese, iron and sulfate were measured (table 10). Some samples did not contain or were not analyzed for dissolved oxygen, and only one sample contained a measurable quantity of sulfide. General redox categories for each sample are listed in table 10 and were assigned using the criteria in tables 2.1 and 2.2 (McMahon and Chapelle, 2008; Chapelle and others, 2009). A complete description of the methods and possible outcomes of redox categories and processes is described in appendix 2 (see also Jurgens and others, 2009).

The redox categories for wells with groundwater samples are identified in figure 38. Groundwater samples with general redox categories classified in this study as "oxic" (table 10) were identified in wells in the eastern uplands subarea, the eastern valley subarea, and in shallow wells in the western valley and western uplands subareas. Groundwater samples with general redox categories classified in this study as "anoxic" (table 10) were present in wells in the eastern valley subarea and in deep wells in the western valley and western uplands subareas.

Groundwater in wells classified as anoxic generally had lower nitrate concentrations (less than $0.4-12.4 \mathrm{mg} / \mathrm{L}$ as N, with a median of $1.92 \mathrm{mg} / \mathrm{L}$ as $\mathrm{N}$ ) than groundwater in wells classified as oxic $(0.031-36.5 \mathrm{mg} / \mathrm{L}$ as $\mathrm{N}$, with a median of $2.05 \mathrm{mg} / \mathrm{L}$ as $\mathrm{N}$ ), which is consistent with the reduction of nitrate in water to nitrogen gas under anoxic conditions 


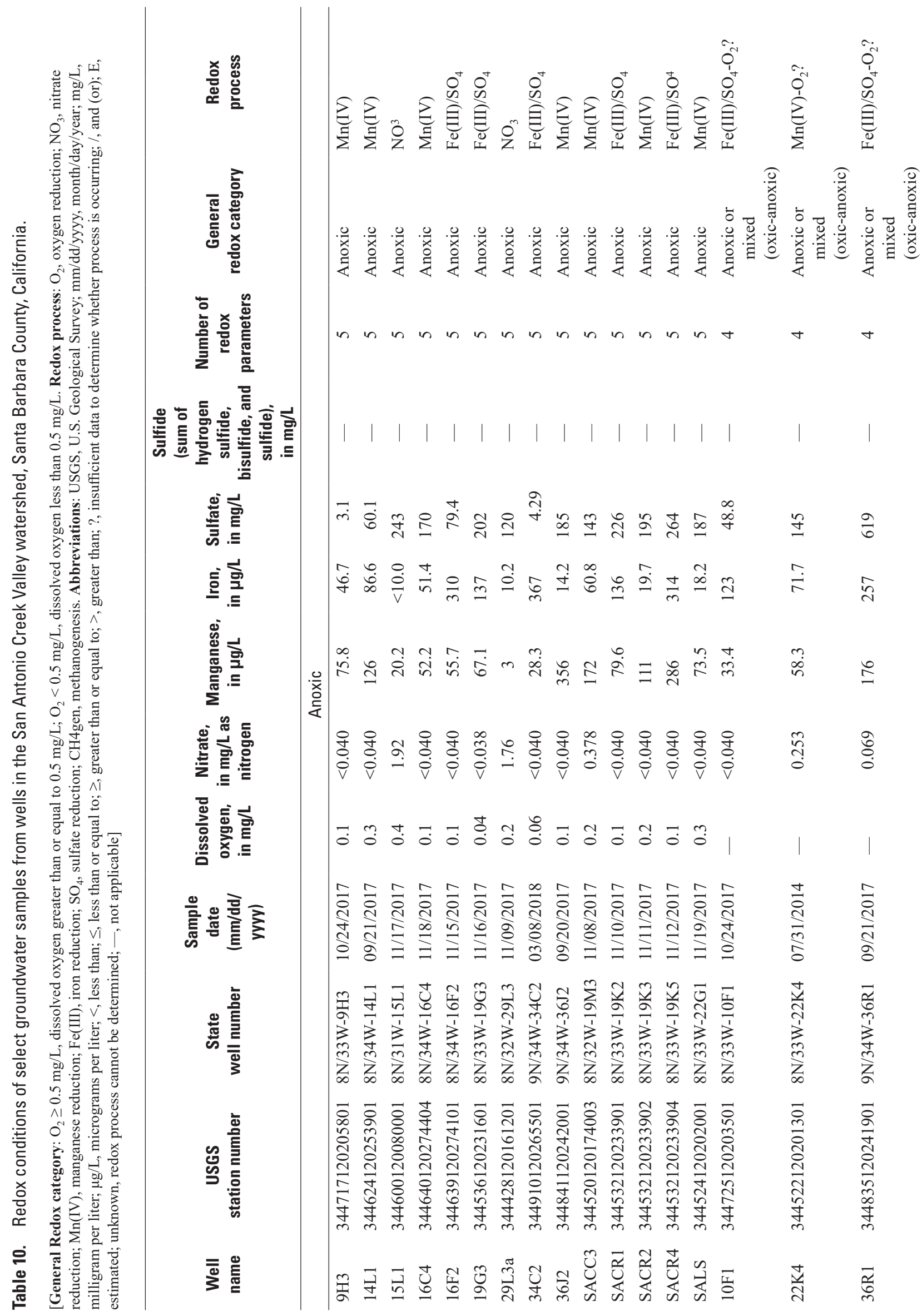



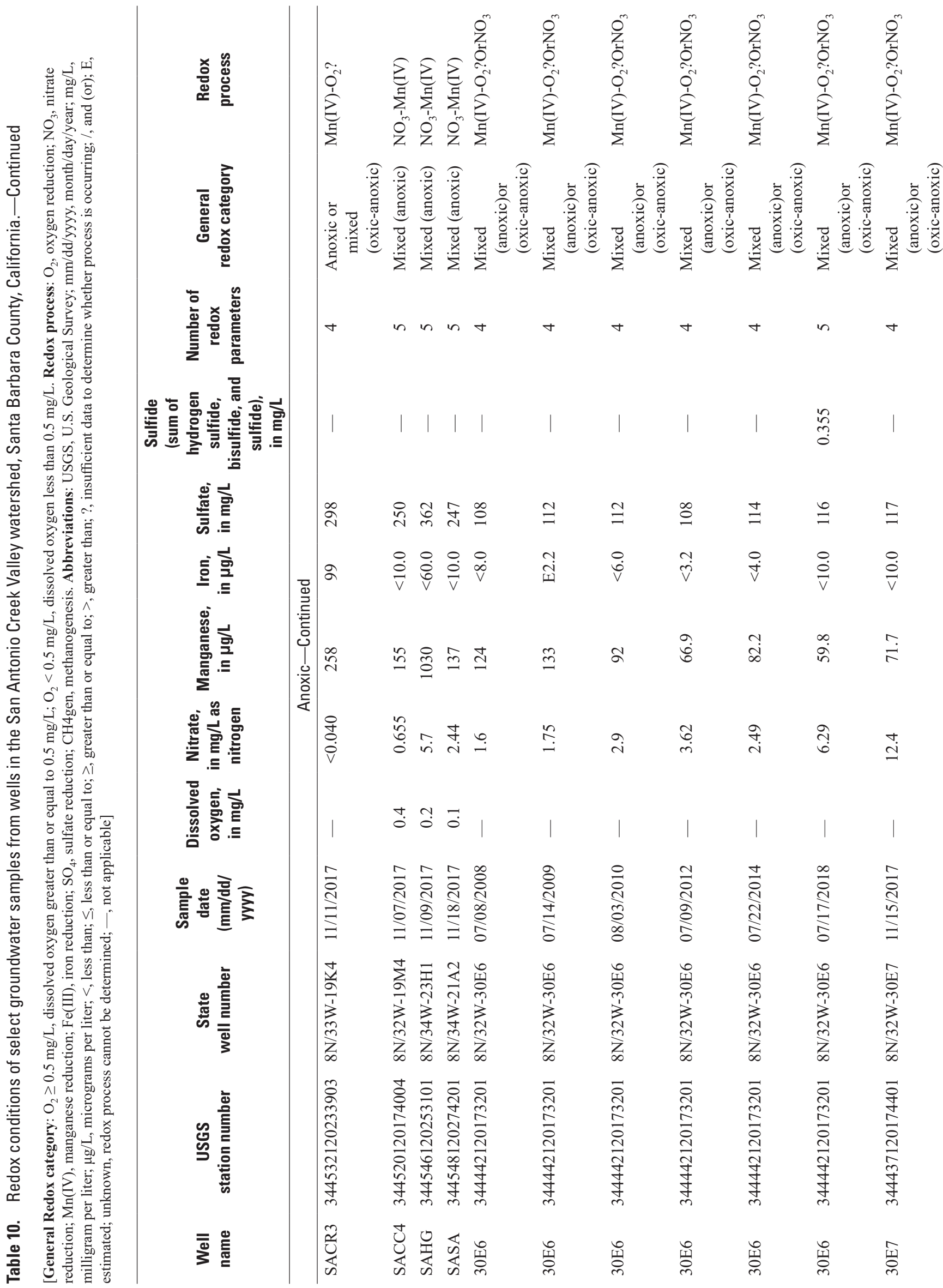


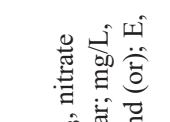

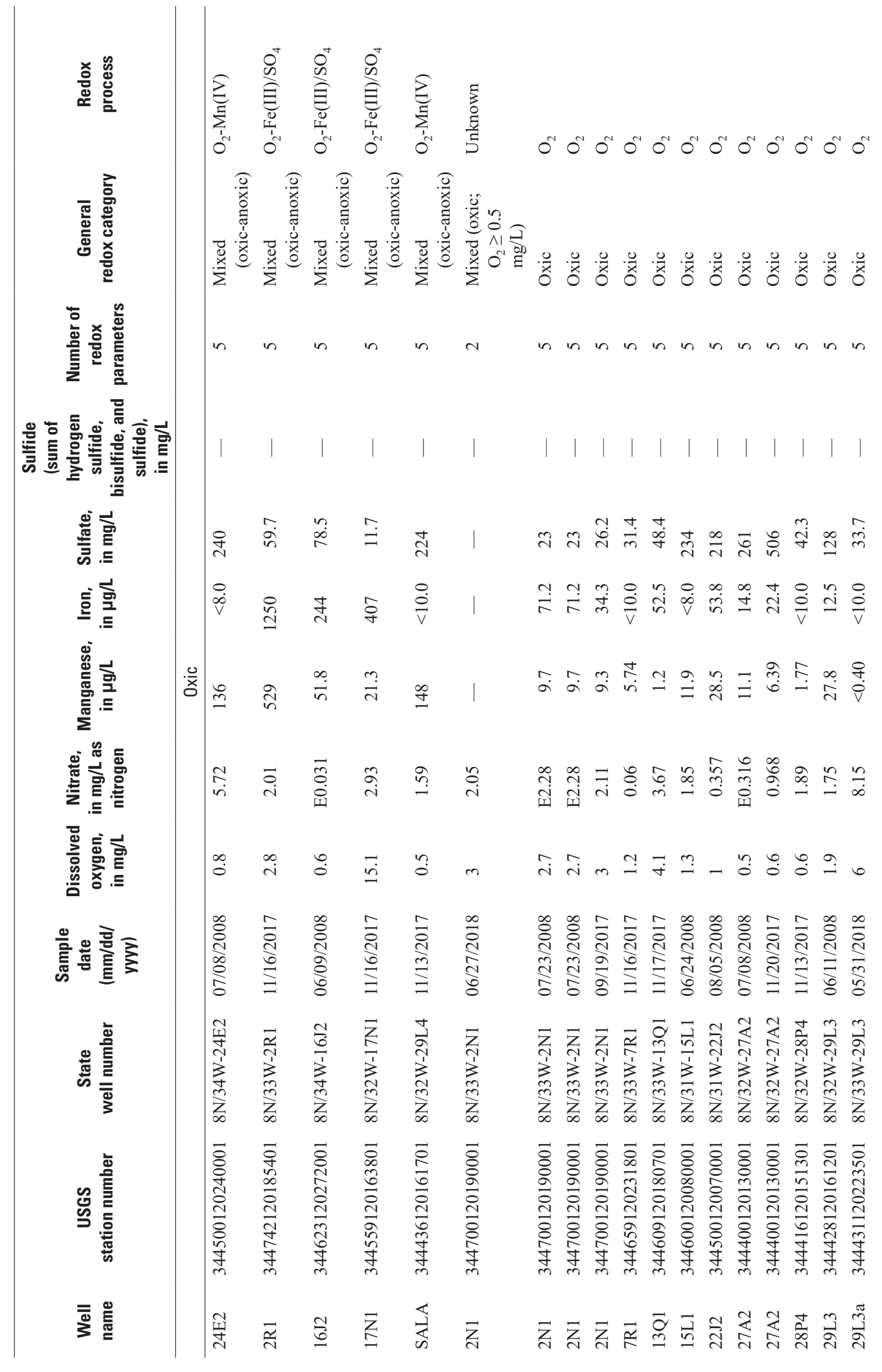


(⿸丆口

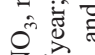

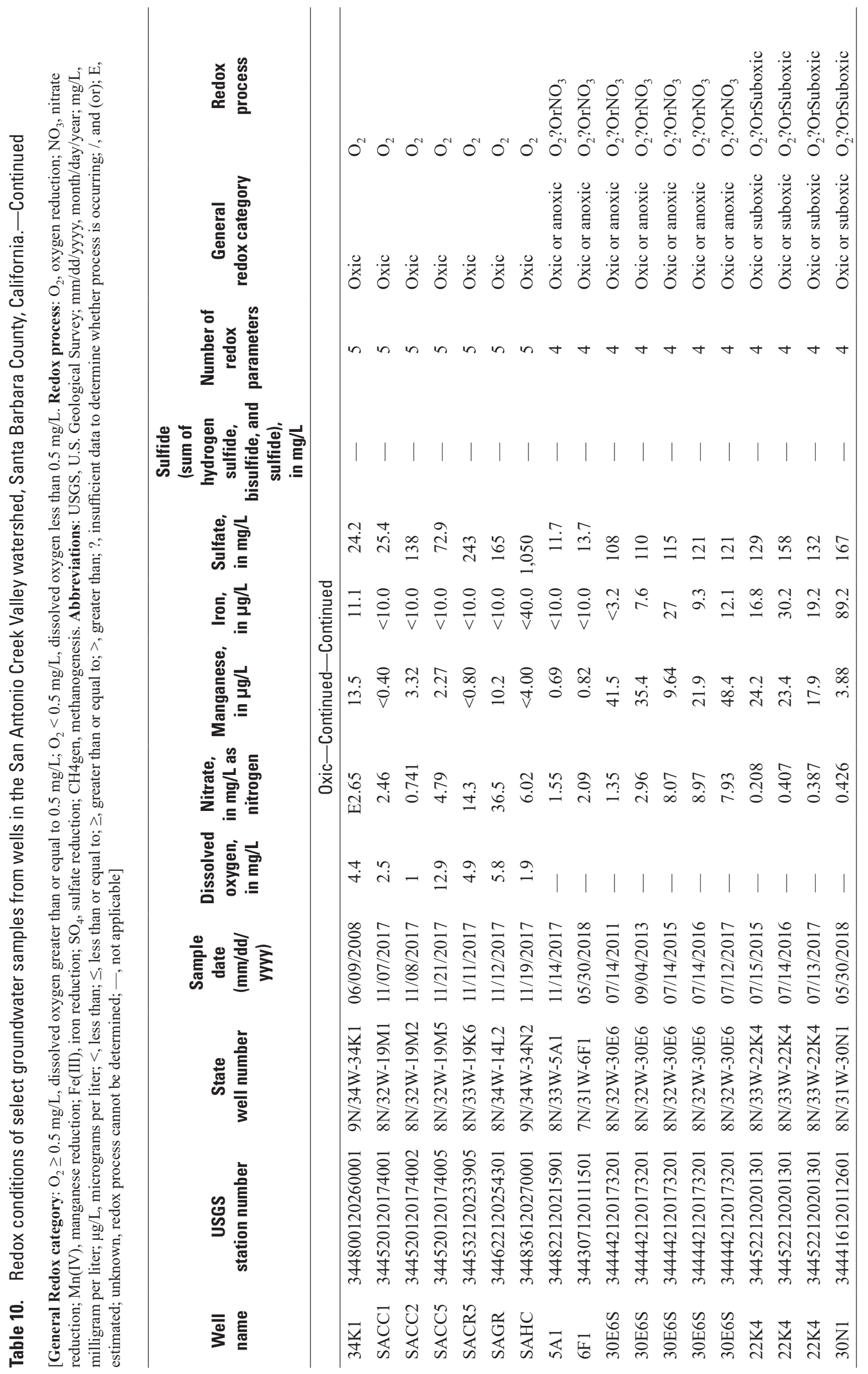


(tables 10,2.2). Anoxic groundwater from wells perforated near the fine-grained middle Paso Robles Formation were likely associated with fine-grained, organic-rich formations. Wells in the western part of the SACVW near Barka Slough were mostly perforated in the lower Paso Robles Formation and Careaga Sandstone and had anoxic groundwater that likely was associated with the discharge of deep, old groundwater (see "Tritium and Carbon-14" section).

\section{Age and Source of Groundwater}

The radioactive isotopes of hydrogen and carbon were used for determining the age (time since recharge) of groundwater, locating sources of recharge, and identifying geologic controls on the movement of groundwater. Similarly, the stable isotopes of oxygen and hydrogen were used as a tracer of the movement, and to understand the source and hydrologic history, of groundwater. In this study, the radioactive isotopes of hydrogen (hydrogen-3 $\left[{ }^{3} \mathrm{H}\right]$, or tritium) and carbon (carbon-14 $\left[{ }^{14} \mathrm{C}\right]$ ) and the stable isotopic ratios of oxygen (oxygen-18 $\left[{ }^{18} \mathrm{O}\right] /$ oxygen- $16\left[{ }^{16} \mathrm{O}\right]$ ) and hydrogen (hydrogen-2 $\left[{ }^{2} \mathrm{H}\right]$ /hydrogen-1 $\left[{ }^{1} \mathrm{H}\right]$ ) were analyzed in groundwater samples from selected wells to help determine the relative age, or time since recharge, source, and movement of groundwater.

\section{Tritium and Carbon-14}

Tritium is a naturally occurring radioactive isotope of hydrogen that has a half-life of 12.4 years (Michel, 1976, 2005). Approximately 800 kilograms of tritium was released into the atmosphere because of the atmospheric testing of nuclear weapons between 1952 and 1962 (Michel, 1976). As a result, tritium concentrations in precipitation and groundwater recharge increased during that time. Tritium concentrations are not affected by chemical reactions other than radioactive decay because tritium is part of the water molecule. Therefore, tritium is a tracer of the movement and relative age of water on timescales ranging from recent to about 60 years before present (years BP; post 1952). The concentration of tritium is typically reported in Tritium Units (TU; Michel, 1976). In this report, groundwater that had tritium concentrations less than the detection limit of $0.2 \mathrm{TU}$ was interpreted as water recharged prior to 1952. Groundwater that had measurable tritium concentrations was interpreted as water recharged after 1952.

Carbon-14 is a naturally occurring radioactive isotope of carbon that has a half-life of about 5,730 years (Mook, 1980). Carbon-14 data are expressed as percent modern carbon (pmC) by comparing ${ }^{14} \mathrm{C}$ activities to the specific activity of National Bureau of Standards oxalic acid, where 13.56 disintegrations per minute per gram of carbon in the year 1950 equals $100 \mathrm{pmC}$ (Kalin, 2000). Similar to tritium, ${ }^{14} \mathrm{C}$ was produced by the atmospheric testing of nuclear weapons (Mook, 1980). As a result, ${ }^{14} \mathrm{C}$ activities may exceed
$100 \mathrm{pmC}$ in areas where meteoric waters recharged aquifers in the 1950s. Carbon-14activities also are affected by mixing younger water that has high ${ }^{14} \mathrm{C}$ activity with older water that has low ${ }^{14} \mathrm{C}$ activity. To estimate relative age, the greatest ${ }^{14} \mathrm{C}$ activity of water that no longer contains tritium is selected as the initial ${ }^{14} \mathrm{C}$ activity of groundwater recharge, $\mathrm{A}_{0}$. This approach is more representative of conditions within the study area and provides a better estimate of the initial ${ }^{14} \mathrm{C}$ activity of groundwater prior to nuclear weapons testing compared to analytical estimates. Using initial ${ }^{14} \mathrm{C}$ activity does not account for radioactive decay that occurred since 1952; however, the decrease in ${ }^{14} \mathrm{C}$ activity resulting from radioactive decay since 1952 is small and is considered negligible based on the half-life of ${ }^{14} \mathrm{C}$. For the SACVW, the $\mathrm{A}_{0}$ was about $75 \mathrm{pmC}$ and is consistent with values estimated in other coastal basins, which ranged from 64 to 69 pmC (Izbicki and others, 1992; O'Leary and others, 2015; Teague and others, 2018).

Carbon-14 activities are used to determine the age of a groundwater sample on timescales generally ranging from about 1,000 to about 15,000 years BP. Carbon-14 is not part of the water molecule; therefore, ${ }^{14} \mathrm{C}$ activities may be affected by chemical reactions that remove or add carbon to solution. Carbon-13 data can aid in the interpretation of ${ }^{14} \mathrm{C}$ activities and are expressed as ratios in delta notation $(\delta)$ as parts per thousand (per mil) differences relative to the ratio of stable isotopes ${ }^{13} \mathrm{C}$ to ${ }^{12} \mathrm{C}$ in standard Pee Dee Belemnite (Gonfiantini, 1978). Carbon-14 ages presented in this report did not account for changes in ${ }^{14} \mathrm{C}$ activity resulting from chemical reactions or mixing; therefore, presented ${ }^{14} \mathrm{C}$ ages were considered uncorrected ages. In general, uncorrected ${ }^{14} \mathrm{C}$ ages were older than the actual age of the associated water. In this report, groundwater that had ${ }^{14} \mathrm{C}$ activities less than $75 \mathrm{pmC}$ was interpreted as being recharged before 1952. Groundwater having ${ }^{14} \mathrm{C}$ activities greater than $75 \mathrm{pmC}$ was interpreted as being recharged after 1952 (Izbicki and Michel, 2003).

For the purposes of age classification in this report, groundwater samples that had tritium concentrations greater than $0.2 \mathrm{TU}$ and ${ }^{14} \mathrm{C}$ activities greater than $75 \mathrm{pmC}$ were considered modern. Water samples that had tritium concentrations less than $0.2 \mathrm{TU}$ and ${ }^{14} \mathrm{C}$ activities less than $75 \mathrm{pmC}$ were considered pre-modern (that is, recharged before 1952). Water samples that had pre-modern and modern water designations from tritium and $\mathrm{pmC}$ were designated as mixed (U.S. Geological Survey, 2021). Groundwater with ${ }^{14} \mathrm{C}$ activity that was less than $75 \mathrm{pmC}$ and had a measurable tritium concentration indicated that other geochemical reactions had occurred within the groundwater system; these reactions may have added carbon that did not contain ${ }^{14} \mathrm{C}$ to the dissolved phase or may have removed carbon, making the water appear older than it is. Groundwater samples in 10 wells were designated as modern, 6 wells were designated as mixed, and 34 wells were designated as pre-modern (U.S. Geological Survey, 2021). 
Concentrations of tritium in $\mathrm{TU}$ and $\mathrm{pmC}$ in groundwater for selected wells are illustrated with depth on four sections through the SACVW from the HFM (fig. 40; locations shown on fig. 36). Each section (same locations as those in fig. 38) shows selected groundwater wells and the perforation interval from which samples were analyzed for each well, and the corresponding hydrogeologic units. Wells with modern groundwater are in the floor of the eastern valley subarea near Los Alamos, in the western uplands subarea along Harris Canyon, and adjacent to tributaries of San Antonio Creek throughout the SACVW; these wells generally have shallow perforations (with approximate well depths of about $270 \mathrm{ft}$ bls), and most were perforated in the channel alluvium, and upper and lower Paso Robles Formation. Wells with pre-modern groundwater were located in the eastern and western uplands subareas, and the eastern and western valley subareas; these wells generally had deep perforations (with average well depths of about $540 \mathrm{ft}$ bls), and most of these wells were perforated in lower Paso Robles Formation, the Careaga Sandstone, or Consolidated bedrock. Wells with mixed groundwater were located throughout with SACVW and generally had average well depths of about $430 \mathrm{ft}$ bls.

The tritium concentrations in groundwater samples from wells sampled during 2008-18 ranged from less than $0.2 \mathrm{TU}$ in numerous wells to $0.91 \mathrm{TU}$ in SACR5 (fig. 40; U.S. Geological Survey, 2021). Groundwater samples from 33 wells did not have measurable tritium concentrations and were considered pre-modern. Groundwater samples from 15 wells had measurable tritium concentrations and were considered modern. The ${ }^{14} \mathrm{C}$ activities in groundwater samples from wells sampled during 2008-18 ranged from $0.1 \mathrm{pmC}$ in well 9N/34W-27L1 to $114.9 \mathrm{pmC}$ in well SAGR (fig. 40A; U.S. Geological Survey, 2021). Uncorrected ages for the water samples ranged from recent (between 1950 and present day) to more than 37,000 yrs BP. Water-quality samples with ${ }^{14} \mathrm{C}$ activities less than $75 \mathrm{pmC}$ that represented older, pre-modern water were collected from 39 wells. Water-quality samples with ${ }^{14} \mathrm{C}$ activities greater than $75 \mathrm{pmC}$ that represented younger, modern water were collected in 10 wells

Measured delta carbon-13 $\left(\delta^{13} \mathrm{C}\right)$ composition of water from wells ranged from 4.25 to 20.49 per mil (U.S. Geological Survey, 2021). Delta carbon-13 values were generally heavier (more positive) in the eastern part of SACVW than in the western part. The heaviest (most positive) $\delta^{13} \mathrm{C}$ value was from groundwater in well 9N/34W-34C2 in the western uplands subarea proximal to the Orcutt Oil Field, and the lightest (most negative) $\delta^{13} \mathrm{C}$ value was from groundwater in well 8N/33W-0R1 in the central uplands subarea (see fig. 36 for well locations). This variability in the $\delta^{13} \mathrm{C}$ data indicates that additional reactions have occurred in the basin; reactions could include (1) the formation of carbonates in an organic rich system which can have produce heavier, more positive, $\delta^{13} \mathrm{C}$ values or (2) the oxidation of biogenic methane (which is depleted in $\delta^{13} \mathrm{C}$ ), which can produce lighter, more negative, $\delta^{13} \mathrm{C}$ values.

\section{Stable Isotopes of Oxygen and Hydrogen}

Oxygen-18 $\left({ }^{18} \mathrm{O}\right)$ and ${ }^{2} \mathrm{H}$ are natural stable isotopes of oxygen and hydrogen, respectively. Delta oxygen-18 $\left(\delta^{18} \mathrm{O}\right)$ and delta ${ }^{2} \mathrm{H}\left(\delta^{2} \mathrm{H}\right)$ are isotopic ratios of oxygen isotopes ${ }^{18} \mathrm{O}$ and ${ }^{16} \mathrm{O}$, and hydrogen isotopes ${ }^{2} \mathrm{H}$ and ${ }^{1} \mathrm{H}$, respectively. These isotopic ratios are expressed as per mil differences, relative to the standard known as Vienna Standard Mean Ocean Water (Gonfiantini, 1978) and are indicators of the hydrologic history of recharge water.

The linear relation between $\delta^{18} \mathrm{O}$ and $\delta^{2} \mathrm{H}$ in natural precipitation throughout the world (Craig, 1961) is referred to as the global meteoric water line (GMWL; fig. 41). The isotopic composition of ocean water undergoes fractionation during the transfer from the ocean surface to the vapor phase. Further fractionation occurs as precipitation condenses from the atmosphere, leaving the remaining water vapor relatively depleted in the heavier isotopes. Latitude, altitude, and air temperature affect the isotopic composition of atmospheric water. Precipitation from a given storm becomes isotopically lighter (more negative) as the storm moves inland and into higher altitudes with cooler temperatures (Fournier and Thompson, 1980). More negative values of $\delta^{18} \mathrm{O}$ and $\delta^{2} \mathrm{H}$ represent enrichment in the lighter isotopes, ${ }^{16} \mathrm{O}$ and ${ }^{1} \mathrm{H}$ (or a depletion in the heavier isotopes, ${ }^{18} \mathrm{O}$ and ${ }^{2} \mathrm{H}$ ); less negative values represent enrichment in the heavier isotope of oxygen $\left({ }^{18} \mathrm{O}\right)$ and hydrogen $\left({ }^{2} \mathrm{H}\right)$, respectively. Water that has undergone evaporation is enriched in heavier isotopes relative to its original composition and generally has values below and to the right of the meteoric water line, with a slope between 3 and 6 (International Atomic Energy Agency, 1981). Isotopic composition of water does not change further at low temperatures of most groundwater systems after recharged water has migrated below the depth of evaporation. Therefore, any subsequent differences in the isotopic composition of groundwater along a flow line generally reflect only mixing within the aquifer system or concentration by evaporation in a discharge area. The $\delta^{18} \mathrm{O}$ and $\delta^{2} \mathrm{H}$ compositions of groundwater relative to the meteoric water line and the isotopic composition of water from other sources can indicate the source of groundwater.

Isotopic compositions of groundwater samples from wells sampled during 2008-18 ranged from -6.22 to -4.86 per mil for $\delta^{18} \mathrm{O}$ and from -42 to -31.7 to per mil for $\delta^{2} \mathrm{H}$ (fig. 41 ; U.S. Geological Survey, 2021). The isotopic data mostly plot to the right of the GMWL, indicating possible evaporation prior to recharge, partial evaporation during precipitation, or a "local" meteoric water line that differs slightly from the GMWL (fig. 41). Water samples from wells were categorized into three main groups: group 1 samples with lighter isotopic composition (more negative) that plot below and down to the right of the GMWL, group 2 samples with intermediate isotopic composition that plot nearest to the GMWL, and group 3 samples with heavier isotopic compositions (less negative) that are characteristic of evaporated groundwater that plot below the GMWL with $\delta^{18} \mathrm{O}$ values of -5.6 and 

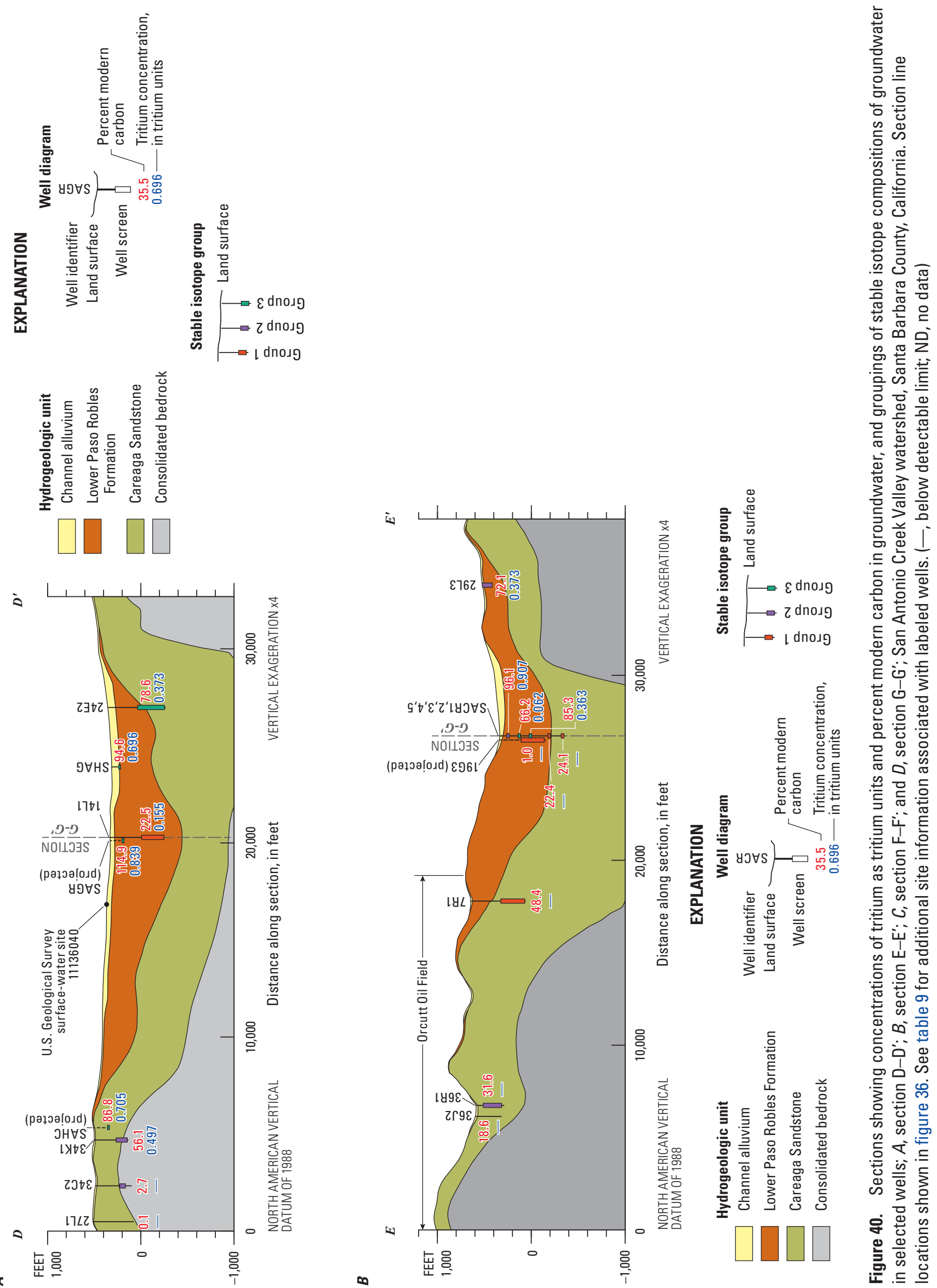

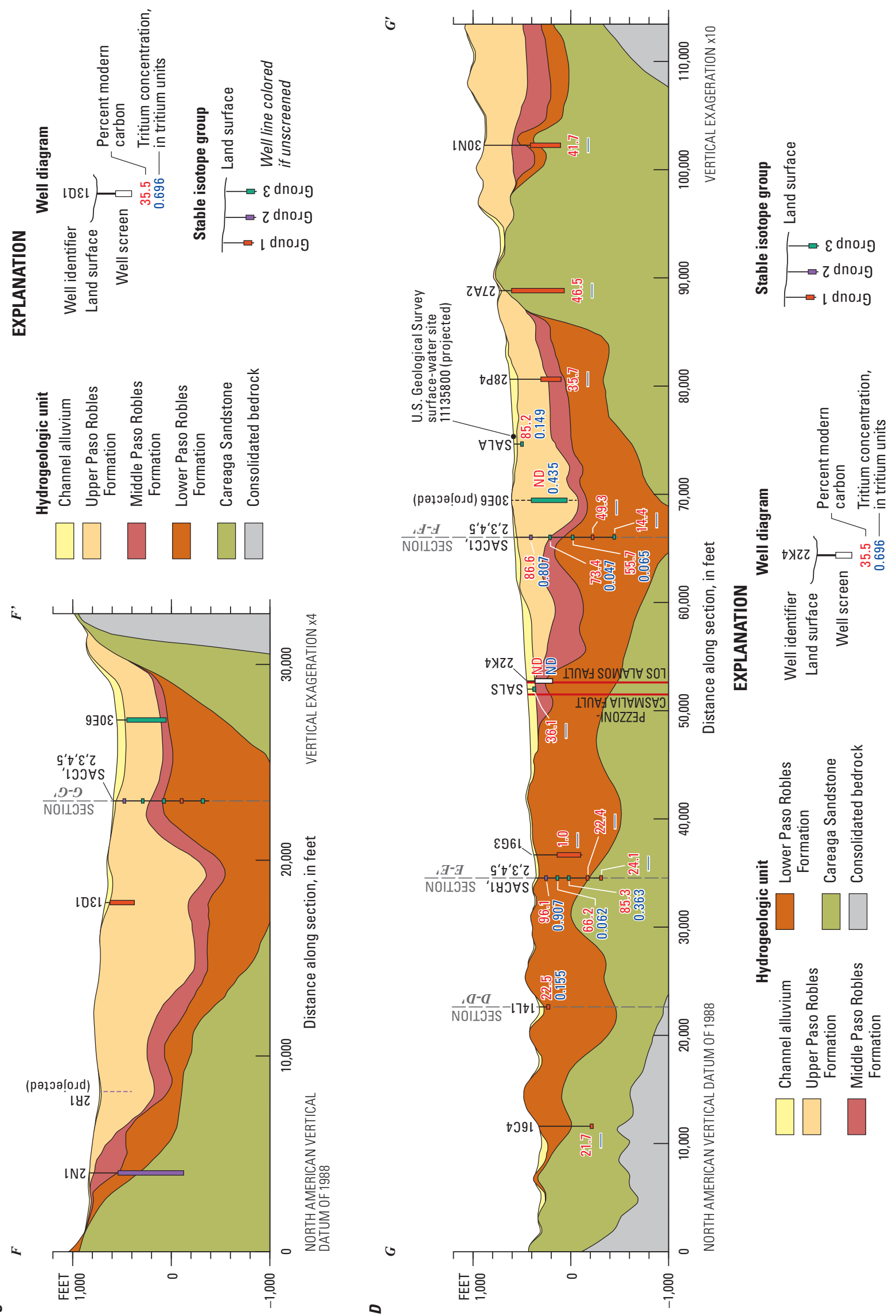

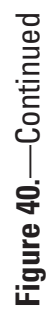




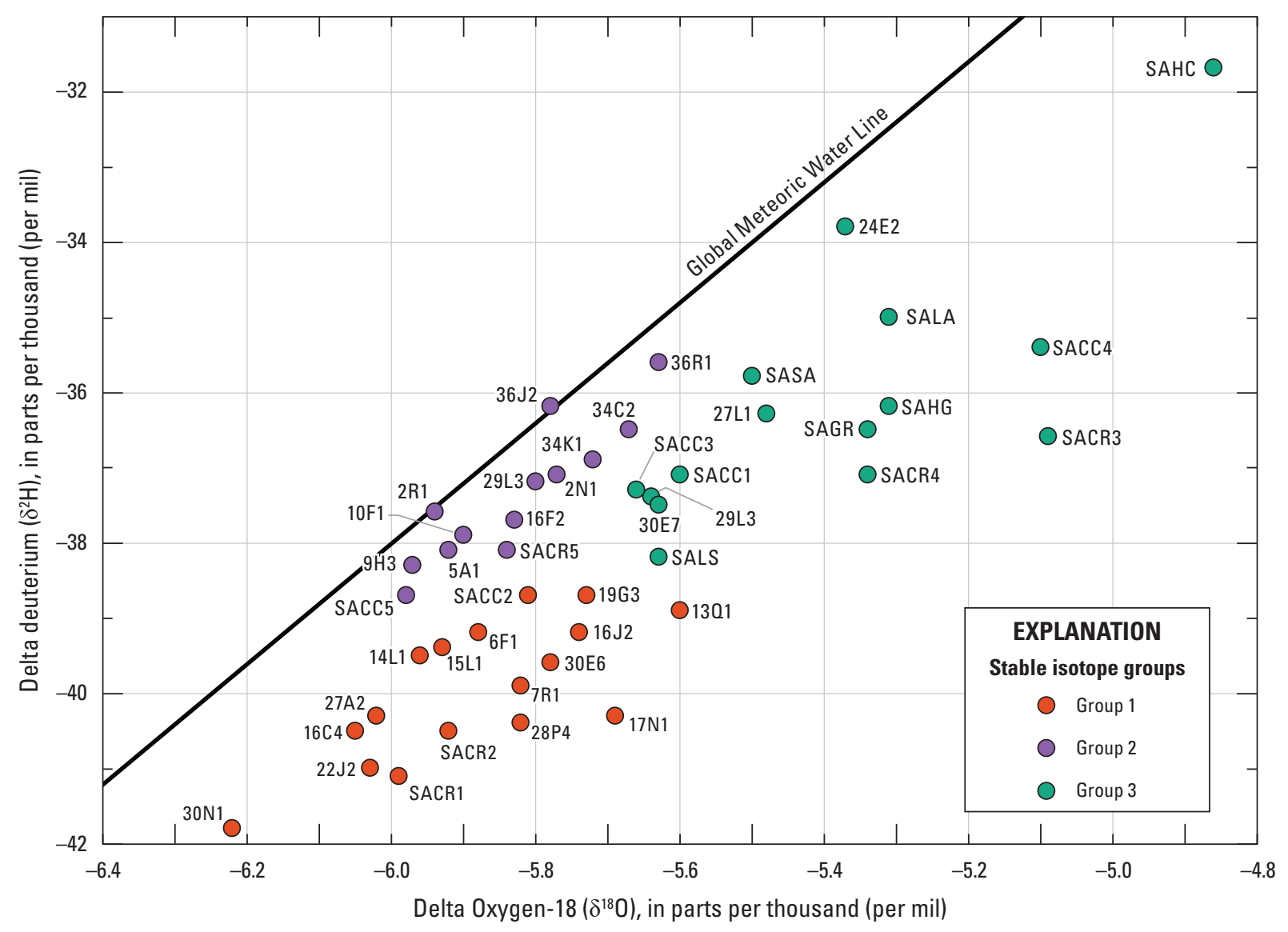

Figure 41. Stable isotope concentrations in parts per thousand (per mil) for groundwater samples from selected wells with respect to the global meteoric water line (GMWL), San Antonio Creek Valley watershed, Santa Barbara County, California. Group 1 samples have light isotopic compositions and plot below and down to the right of the GMWL; group 2 samples have intermediate isotopic compositions and plot close to the GMWL; group 3 samples have heavy isotopic compositions and plot below and to the right of the GMWL. See table 9 for additional site information associated with labeled wells.

greater (fig. 41). Stable isotopic groundwater groups for selected wells are shown in map view in figure 42 and in sections on figure 40. The Pezzoni-Casmalia and Los Alamos faults are inferred to transect the SACVW between the western and eastern areas of the valley floor and do not markedly affect stable isotopic compositions of groundwater in the SACVW.

Group 1 groundwater samples (indicated by red symbols in figs. 40,41,42) were primarily from deep wells, in the eastern uplands and western valley subareas, and from wells in the Barka Slough subarea or where deep groundwater discharges to land surface. Group 1 samples represent old, pre-modern groundwater, with the exception of well 8N/34W-16J2; this well was located in Barka Slough and had measurable tritium (concentrations greater than $0.2 \mathrm{TU}$ ) and contained some modern groundwater (U.S. Geological Survey, 2021). Group 1 samples plot below and down to the right of the GMWL (fig. 41), indicating that the water was locally recharged during different climate conditions was slightly evaporated when recharged. The geographic and vertical distribution of group 1 samples within the SACVW indicates that recharge occurred from different moisture sources in the eastern uplands subarea and groundwater from the eastern uplands subarea has a long, slow travel time to the western part of the SACVW, where the water eventually discharges as base flow at Barka Slough (as indicated by the presence of group 1 groundwater in wells $8 \mathrm{~N} / 34 \mathrm{~W}-16 \mathrm{C} 4$ and $8 \mathrm{~N} / 34 \mathrm{~W}-16 \mathrm{~J} 2$; figs. $40 \mathrm{D}, 41,42$ ). Along this flow path, groundwater may be extracted as groundwater pumpage from deep wells in the western valley or eastern uplands subareas. The presence of pre-modern groundwater in the western part of the SACVW corresponds with the relatively stable groundwater levels observed in wells in the western valley subarea (wells $8 \mathrm{~N} / 33 \mathrm{~W}-20 \mathrm{Q} 1$ and $8 \mathrm{~N} / 33 \mathrm{~W}-20 \mathrm{Q} 2$, and 8N/34W-23B1 and 8N/34W-24E1; hydrographs 10 and 11, respectively, in figs. 34,35 ) and the upward vertical gradient of groundwater flow at multiple-depth, monitoring-well site SACR (figs. 19, 34; U.S. Geological Survey, 2021).

Group 2 groundwater samples (indicated by purple dots in figs. 40, 41, 42) were from shallow and deep wells primarily in the central and western uplands subareas and 

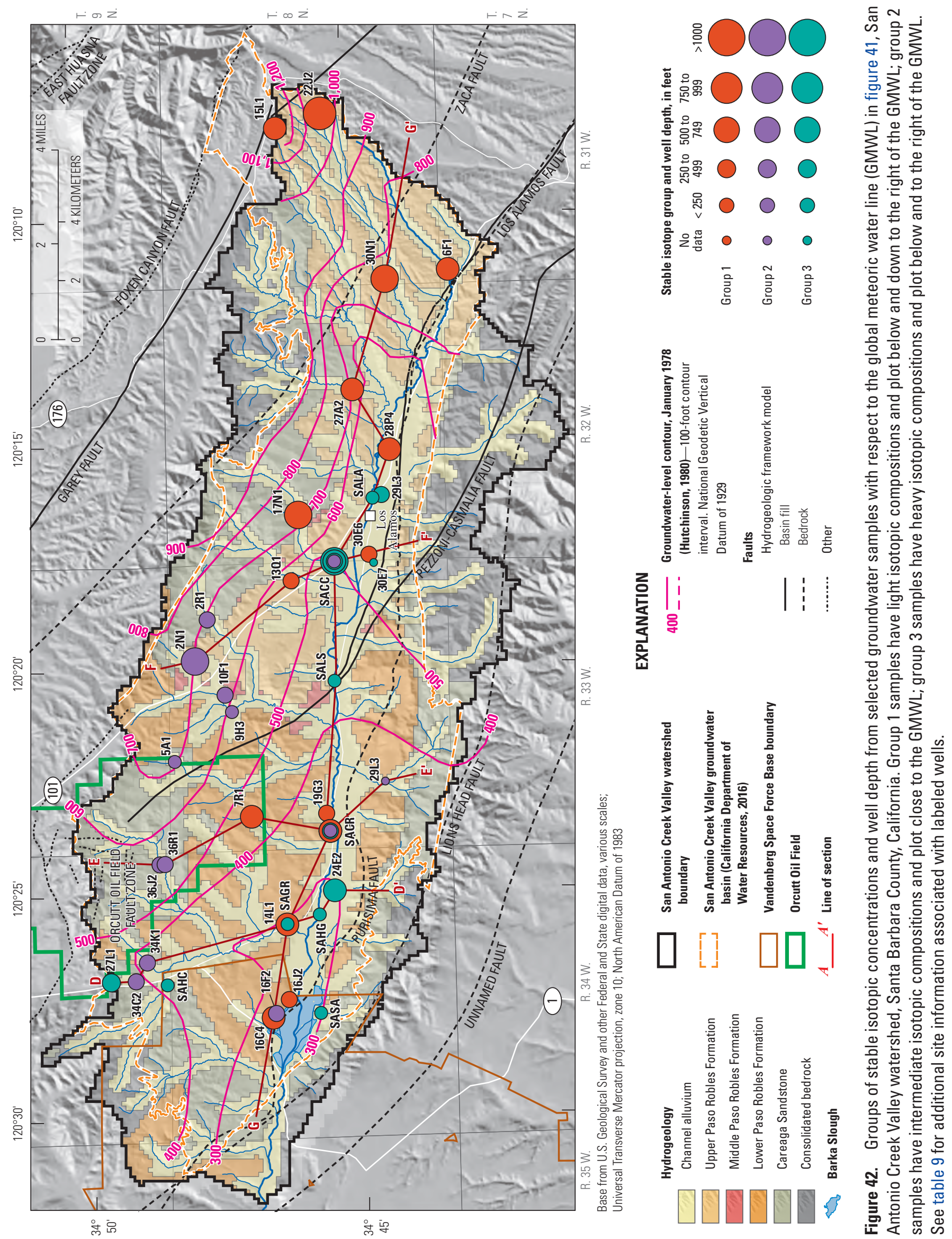
are a mix of modern and pre-modern water (U.S. Geological Survey, 2021). Groundwater samples in group 2 generally plot parallel to the GMWL (fig. 41) and likely represent a "local" meteoric water line. The local meteoric water line consists of modern and pre-modern local recharge from precipitation that had relatively short travel times and was discharged as base flow at Barka Slough (as indicated by the presence of group 2 groundwater at well $8 \mathrm{~N} / 34 \mathrm{~W}-16 \mathrm{~F} 2$; fig. 42) or otherwise extracted as groundwater pumpage.

Group 3 groundwater samples (indicated by green dots in figs. 40, 41, 42) were from shallow and deep wells primarily in the eastern and western valleys and were a mix of modern and pre-modern water (U.S. Geological Survey, 2021). Groundwater samples in group 3 plotted below the GMWL (fig. 41), indicating either mixing with evaporated surface water or mixing with and additional evaporation of deep discharge groundwater from group 1 or group 2. Wells SAHC, SALA, SASA, SAHG, SAGR, and SALS are shallow wells (less than $250 \mathrm{ft}$ depth bls) and are proximal to San Antonio Creek or its tributaries (table. 1.2; figs. 40, 42); stable isotopic compositions of groundwater in these wells may indicate evaporated surface flow draining from sediments along the stream channels. The remaining wells in group 3 (such as 8N/34W-24E2, SACC-1, SACC-3, SACC-4, SACR-3, and $8 \mathrm{~N} / 32 \mathrm{~W}-29 \mathrm{~L} 3$ ) are deep wells (greater than $250 \mathrm{ft}$ depth bls); groundwater in these wells may be mixed with deep groundwater (recharged under different climate conditions) characterized by wells in group 1 .

\section{Summary}

Working cooperatively with the Santa Barbara County Water Agency and Vandenberg Space Force Base, the U.S. Geological Survey (USGS) initiated a study to better understand the hydrogeology and water resources in the San Antonio Creek Valley groundwater basin, California. The goals of the study were to address declines in groundwater levels, develop a better understanding of the hydrogeologic system, and provide tools to help evaluate and manage the effects of future development of the San Antonio Creek Valley groundwater basin within the encompassing San Antonio Creek Valley watershed (SACVW). The SACVW is in western Santa Barbara County about 15 miles south of Santa Maria and 55 miles north of Santa Barbara, California. The SACVW is about 140 square miles and encompasses the San Antonio Creek Valley groundwater basin; the SACVW is separated from the Santa Maria River Valley and Santa Ynez River Valley groundwater basins by the Casmalia and Solomon Hills to the north, and the Purisima Hills to the south. At the western, downstream part of the valley, uplifted consolidated rocks cause groundwater to discharge to San Antonio Creek at Barka Slough. Since the late 1800s, groundwater has been the primary source of water for agricultural, military, municipal, and domestic uses. Groundwater withdrawal from pumping has exceeded the amount of water replenishing the basin, causing groundwater declines of more than 125 feet in parts of the valley, and a reduction in base flow at Barka Slough. Agricultural water use, primarily for the irrigation of vineyards and fruit and berry crops, and reliance on groundwater for irrigation will continue to strain the sustainability of the groundwater system.

The SACVW has a semiarid climate characterized by a wet season and dry season. Average monthly precipitation in the town of Los Alamos ranges from about 0.02 inches per year in July to about 3.2 inches per year in February. About 92 percent of annual precipitation recorded in Los Alamos during 1948-2018 falls during the wet season from November to April, and the average annual recorded precipitation during 1948-2018 was about 15 inches per year.

Land in the SACVW has been used primarily for agriculture. Historically, the upland parts of the valley have been used for dry farming or pastureland, and the valley floor along San Antonio Creek and its tributaries were used for irrigated farming. Since the 1980s, however, large sections of formerly non-irrigated pastureland in the uplands have been converted to irrigated vineyards. Detailed land-use maps of the SACVW show an increase in agricultural land use for 1959-2016 of 8,674 acres to 14,080 acres, and an accompanying shift from predominantly non-irrigation dry farming in 1959, to almost entirely irrigated farming in 2016.

The groundwater-flow system in the SACVW consists of five basin-fill hydrogeologic units. These units are water-bearing and were identified based on hydrogeologic properties, such as sediment grain size, vertical-head differences in groundwater multiple-monitoring well sites, long-term groundwater-level altitude responses to pumping and climate, and the age and chemical character of groundwater in the mostly semi-consolidated to unconsolidated basin-fill sediments. The hydrogeologic units that comprise the aquifer system vary in their lithologic composition. The upper and lower units of the aquifer system (upper Paso Robles Formation, and lower Paso Robles Formation and Careaga Sandstone, respectively) are relatively coarse grained and are composed of, sand, gravel, and clay; the middle confining unit (the middle Paso Robles Formation) is relatively fine grained and is composed of primarily clay, silt, and sand. The Pezzoni-Casmalia and Los Alamos faults, which are inferred to transect the SACVW between the western and eastern parts of the valley, do not appear to affect the groundwater system.

Present-day recharge to the study area occurs primarily as infiltration from precipitation and streams in the upland areas of the valley in Solomon Hills and Casmalia Hills and along the main channel of San Antonio Creek; estimates of annual natural recharge for 1948-2018 generally range from about 5,000 acre-feet per year to more than about 30,000 acre-feet per year. Anthropogenic sources of recharge, such as return flow from agricultural irrigation, municipal water systems, and wastewater effluent, have been additional sources of recharge to the groundwater system and were estimated to range from 
about 600 acre-feet in 1948 to about 6,600 acre-feet in 2018 . Groundwater pumpage estimates for agricultural, military, municipal, and domestic use during 1948-2018 ranged from about 3,000 acre-feet in 1948 to about 32,600 acre-feet in 2018. During this time period, pumpage for agricultural use accounted for about 90 percent of the total groundwater pumpage in the SACVW. The average annual amount of groundwater removed from the SACVW by pumping during 1948-2018 was estimated to be about 17,200 acre-feet per year, which was between about 10 percent to more than 300 percent greater than most estimates of annual recharge to the valley.

Pumpage since the early 1900 s and the subsequent groundwater-level declines have substantially reduced the amount of natural groundwater discharge at Barka Slough. Estimates of the amount of base flow in San Antonio Creek at the western, downstream extent of the SACVW have varied historically in response to changes in groundwater pumpage and climate; however, there was an overall decline in base flow during 1956-2018, decreasing from an average of about 1,700 acre-feet per year during 1956-69, to about 300 acre-feet per year during 2016-18. The long-term extraction of groundwater has caused groundwater levels to decrease by more than about 125 feet since the early 1940s in the eastern part of the valley near Los Alamos and as much as about 50 feet in the upland areas and in the western part of the basin. In the eastern part of the valley, groundwater levels in shallow wells perforated in the upper Paso Robles Formation declined by about $50 \mathrm{ft}$, whereas groundwater levels in deeper wells perforated in the middle and lower Paso Robles Formation declined by about $125 \mathrm{ft}$. At Barka Slough, groundwater levels have declined below land surface in some places, altering native riparian vegetation in and around the slough.

The predominant direction of groundwater flow during historical and present-day conditions was from the eastern uplands in the Solomon Hills to the west along San Antonio Creek toward Barka Slough from the western and southern uplands uplands in the Casmalia and Purisima Hills to the south and north towards San Antonio Creek. Natural discharge of deep groundwater occurs as base flow to San Antonio Creek in the western part of the SACVW. Stable and radioactive isotopes show that deep groundwater in the SACVW is old and probably was recharged as infiltration from precipitation and streams in the eastern upland areas of the valley.

The quality of surface water in the SACVW varied depending on location and the time of year the samples were collected. In winter 2017, surface water was calcium-sulfate-type water, and the concentration of total dissolved solids (TDS) ranged from about 150 milligrams per liter $(\mathrm{mg} / \mathrm{L})$ to about $1,370 \mathrm{mg} / \mathrm{L}$; in fall 2017 , surface water was mixed cation-chloride-type water, and the TDS concentration ranged from about $1,080 \mathrm{mg} / \mathrm{L}$ to about $1,580 \mathrm{mg} / \mathrm{L}$. Surface-water concentrations of TDS during 1980-2018 generally varied with respect to the amount of annual precipitation and ranged from about 2,000 to
$2,500 \mathrm{mg} / \mathrm{L}$ during wet years, to about 1,000 to $1,500 \mathrm{mg} / \mathrm{L}$ during dry years at the downstream U.S. Geological Survey streamgage 11136100.

Most groundwater in the SACVW was calcium-bicarbonate-type water that was representative of water naturally recharged as infiltration from precipitation and streams. Water-quality compositions of groundwater in some wells showed influences of mixing with water associated with oil-bearing geologic formations, agricultural products, or the evaporation of shallow groundwater. Groundwater associated with naturally recharged water had TDS concentrations of about $500-800 \mathrm{mg} / \mathrm{L}$ and was found in wells throughout the SACVW. Groundwater samples from four wells in the Casmalia Hills had TDS concentrations between about 1,130 and $7,920 \mathrm{mg} / \mathrm{L}$ and indicated possible mixing with water from oil-bearing formations or older, saline groundwater associated with the Orcutt Oil Field. Groundwater samples from nine wells in the western part of the SACVW had TDS concentrations between about 800 and $1,500 \mathrm{mg} / \mathrm{L}$; the source(s) of saline-rich water in these wells could not be conclusively identified, but the saline-rich water could be due to mixing with water from oil-bearing formations or with water from agricultural irrigation-return flow, precipitation of minerals in the subsurface, or solute concentration through evaporation.

Concentrations of TDS, chloride, nitrate plus nitrite (as nitrogen), calcium, and magnesium at selected wells generally increased during 1980-2018; this increase may be associated with the expansion of agriculture in the SACVW through time and corresponding increase in the use of nitrates and calcium- and magnesium-based fertilizers and soil additives in modern agricultural practices. An analysis of the reduction/ oxidation (redox) conditions of groundwater showed that oxic groundwater was found throughout the SACVW, generally in shallow wells, and likely associated with recently recharged groundwater. Anoxic groundwater was generally found in wells perforated adjacent to the middle Paso Robles Formation, likely associated with the fine-grained, organic-rich materials of that unit; and in wells located in the western part of the SACVW near Barka Slough, likely associated with the discharge of deep, old groundwater.

Radioactive isotopes tritium and carbon-14 and stable isotopes of oxygen and hydrogen were used to evaluate the age and flow of groundwater in the SACVW. Uncorrected ages for groundwater samples ranged from recent to more than 37,000 years old. Modern groundwater (recharged after 1952) was generally found in shallow wells (about 270 feet below land surface) adjacent to San Antonio Creek and its tributaries. Pre-modern groundwater (recharged before 1952) was found throughout the SACVW in wells that generally had deep perforations; the average perforation depths of these wells was $540 \mathrm{ft}$ below land surface. Modern and pre-modern groundwater were identified in wells along San Antonio Creek and its tributaries and in the western and central upland areas of the SACVW. Pre-modern groundwater identified in wells in the eastern upland area was interpreted to have had long, 
slow travel times to the western part of the SACVW, where it was eventually discharged as base flow at Barka Slough or extracted as groundwater pumpage.

The hydrologic characterization of the SACVW presented in this study supported the development of an integrated numerical hydrologic model of the valley. The integrated model further refines the hydrologic understanding of the SACVW and can be used as a tool to simulate future water-management scenarios under different climatic and hydrologic conditions. Continued groundwater monitoring, especially multiple-depth, monitoring-well sites, and surface-water monitoring, especially streamgages proximal to Barka Slough, will add to the existing record of hydrologic data in the SACVW and provide long-term observations that can be used to inform and evaluate water management decisions.

\section{References Cited}

American Association of Petroleum Geologists (AAPG), 1959, Correlation section across Santa Maria basin from outcrop in Santa Ynez Mountains northerly to outcrop north of Santa Maria River, California: Pacific Section AAPG Published Correlation Sections 12, scales 1:4,000 and $1: 1,000$.

Arnold, L.R., 2015, Monitoring-well installation, slug testing, and groundwater quality for selected sites in South Park, Park County, Colorado, 2013: U.S. Geological Survey Open-File Report 2014-1231, 32 p., accessed July 23, 2021, at https://doi.org/10.3133/ofr20141231.

Barbash, J., and Bell, R., 2002, Methods for collecting data on hydrogen sulfide in groundwater during the National Water Quality Assessment (NAWQA) Program and entering them into NWIS: written communication to NAWQA study units, dated September 5, 2002, accessed on April 28, 2017, at http://nm.water.usgs.gov/nawqa_natsyn/hydrogen.sulfide/ H2S_coding+method_descr.doc.

Barlow, P.M., Cunningham, W.L., Zhai, T., and Gray, M., 2017, U.S. Geological Survey Groundwater Toolbox version 1.3.1-A graphical and mapping interface for analysis of hydrologic data: U.S. Geological Survey software release, May 26, 2017, accessed July 2, 2020, at https://doi.org/10.5066/F7R78C9G.

Bouwer, H., 1986, Intake rate-Cylinder infiltrometer, chap. 32 in Klute, A., ed., Methods of soil analysis-Part 1, Physical and mineralogical methods, 5.1 (2d ed.): Soil Science Society of America, p. 825-844. [Available at https://doi.org/10.2136/sssabookser5.1.2ed.c32.]
Bouwer, H., and Rice, R.C., 1976, A slug test for determining hydraulic conductivity of unconfined aquifers with completely or partially penetrating wells: Water Resources Research, v. 12, no. 3, p. 423-428. [Available at https://doi.org/10.1029/WR012i003p00423.]

Bright, D.J., Nash, D.B., and Martin, P., 1997, Evaluation of ground-water flow and solute transport in the Lompoc area, Santa Barbara County, California: U.S. Geological Survey Water-Resources Investigations Report 97-4056, 113 p. [Available at https://doi.org/10.3133/wri974056.]

Burow, K.R., Shelton, J.L., Hevesi, J.A., and Weissmann, G.S., 2004, Hydrogeologic characterization of the Modesto area, San Joaquin Valley, California: U.S. Geological Survey Scientific Investigations Report 2004-5232. [Available at https://doi.org/10.3133/sir20045232.]

Burton, C.A., and Belitz, K., 2013, Groundwater quality in the South Coast Range Coastal groundwater basins, California: U.S. Geological Survey Fact Sheet 2013-3015, 4 p. [Available at https://doi.org/10.3133/fs20133015.]

Burton, C.A., Land, M.T., and Belitz, K., 2013, Status and understanding of groundwater quality in the South Coast Range - Coastal study unit, 2008 - California GAMA Priority Basin Project: U.S. Geological Survey Scientific Investigations Report 2013-5053, 86 p. [Available at https://doi.org/10.3133/sir20135053.]

Butler, J.J., and Garnett, E.J., 2000, Simple procedures for analysis of slug tests in formations of high hydraulic conductivity using spreadsheet and scientific graphics software: Kansas Geological Survey Open-file Report 2000-40, December 2000, accessed July 17, 2000, at http://www.kgs.ku.edu/Hydro/Publications/OFR00_40/.

Butler, J.J., Jr., Garnett, E.J., and Healey, J.M., 2003, Analysis of slug tests in formations of high hydraulic conductivity: Ground Water, v. 41, no. 5, p. 620-631. [Available at https://doi.org/10.1111/j.1745-6584.2003.tb02400.x.]

California Department of Conservation, 2008, 2008 Annual report of the state oil and gas supervisor: Division of Oil, Gas, and Geothermal Resources Publication PR06, 272 p., accessed May 20, 2021, at https://filerequest.conservation.ca.gov/?q=annual_re ports\%202008\%20PR06_Annual_2008.pdf.

California Department of Conservation, 2018, Farmland mapping and monitoring program: accessed October 26, 2018, at https://gis.conservation.ca.gov/portal/home/ item.html?id=c278df0ef3bc4476bb890e5509bcc5cf.

California Department of Fish and Wildlife, 2021, California natural diversity database: Biogeographic Information and Observation System, v. 5.96.99, accessed November 10, 2021, at https://apps.wildlife.ca.gov/bios/. 
California Department of Water Resources, 1959, Santa Barbara County land use survey.

California Department of Water Resources, 1968, Santa Barbara County land use survey.

California Department of Water Resources, 1971, Ground water quality and hydrology data San Antonio Creek Basin, memorandum report., $19 \mathrm{p}$.

California Department of Water Resources, 1977, Santa Barbara County land use survey.

California Department of Water Resources, 2000, 1996 South central coast land use survey, accessed November 1, 2018, at https://water.ca.gov/Programs/Water-Use-And-Efficiency/ Land-And-Water-Use/Land-Use-Surveys.

California Department of Water Resources, 2016, California's groundwater, working toward sustainability: California Department of Water Resources Bulletin 118, Interim Update 2016, accessed May 23, 2018, at https://www.water.ca.gov/Programs/GroundwaterManagement/Bulletin-118.

California Division of Oil, Gas and Geothermal Resources, 1982, Oil and gas prospect wells drilled in California through 1980: California Division of Oil, Gas and Geothermal Resources Report TR01, 258 p.

California Irrigation Management Information (CIMIS), 2005, Department of Water Resources and University of California, Davis: data accessed on March 31, 2010, at http://cimis.water.ca.gov/.

Carlson, J., 2019, Investigation of pervasive clay layers and their effect on groundwater flow using electrical resistivity tomography in the San Antonio groundwater basin: Senior research product, California Polytechnic State University at San Luis Obispo, Department of Natural Resources Management and Environmental Sciences, Senior Research Project. [Available at https://digitalcommons.calpoly.edu/nrmsp/56.]

Chapelle, F.H., Bradley, P.M., Thomas, M.A., and McMahon, P.B., 2009, Distinguishing iron-reducing from sulfate-reducing conditions: Ground Water, v. 47, no. 2, p. 300-305. [Available at https://doi.org/10.1111/j.1745-6584.2008.00536.x.]

Chow, V.T., 1964, Handbook of applied hydrology: New York, McGraw-Hill, 1418 p.
Cleath-Harris Geologists, 2018, Los Osos Valley groundwater basin boundary modification request: Technical Memorandum prepared for San Luis Obispo Flood Control and Water Conservation District, accessed October 21, 2019, at https://www.slocounty.ca.gov/Departments/ Public-Works/Forms-Documents/Committees-Programs/ Sustainable-Groundwater-Management-Act-(SGMA)/ Los-Osos-Valley-Groundwater-Basin/Los-Osos-BasinBoundary-Modification-Request-Techn.aspx.

Cooper, H.H., Jr., Bredehoeft, J.D., and Papadopulos, S.S., 1967, Response of a finite-diameter well to an instantaneous charge of water: Water Resources Research, v. 3, no. 1, p. 263-269. [Available at https://doi.org/10.1029/WR003i001p00263.]

Coplen, T.B., 1994, Reporting of stable hydrogen, carbon, and oxygen isotopic abundances: Pure and Applied Chemistry, v. 66, p. 273-276. [Available at https://doi.org/10.1351/pac199466020273.]

Coplen, T.B., Wildman, J.D., and Chen, J., 1991, Improvements in the gaseous hydrogen-water equilibration technique for hydrogen isotope ratio analysis: Analytical Chemistry, v. 63, no. 9, p. 910-912. [Available at https://doi.org/10.1021/ac00009a014.]

Craig, H., 1961, Isotopic variation in meteoric waters: Science, v. 133, no. 3465, p. 1702-1703. [Available at https://doi.org/10.1126/science.133.3465.1702.]

Crawford, F.D., 1971, Petroleum potential of Santa Maria Province, California, in Cram, I.H., ed., Future petroleum provinces of the United States-Their geology and potential: American Association of Petroleum Geologists Memoir 15,v. 1, p. 316-328. [Available at https://doi.org/10.1306/M15370C22.]

Descheneaux, R.V., 1975, New water wells in San Antonio watershed: Vandenberg Air Force Base Environmental Impact Report, 4392d Civil Engineering Squadron, 19 p.

Dettinger, M.D., 2011, Climate change, atmospheric rivers, and floods in California-A multimodel analysis of storm frequency and magnitude changes: Journal of the American Water Resources Association, v. 47 , no. 3, p. 514-523, accessed July 2, 2020, at https://doi.org/10.1111/j.1752-1688.2011.00546.x.

Dial, K.P., and Pisapia, R.C., 1980, Barka Slough—Resources inventory and management recommendations: U.S. Fish and Wildlife Service, Division of Ecological Service, Laguna Niguel, California, $50 \mathrm{p}$. 
Dibblee, T.W., Jr., 1950, Geology of southwestern Santa Barbara County, California-Point Arguello, Lompoc, Point Conception, Los Olivos, and Gaviota Quadrangles: California Department of Natural Resources, Division of Mines, Bulletin 150, $135 \mathrm{p}$.

Dibblee, T.W., Jr., and Ehrenspeck, H.E., eds., 1988, Geologic map of the Lompoc and Surf quadrangles, Santa Barbara County, California: Dibblee Geological Foundation, Map DF-20, scale 1:24000.

Dibblee, T.W., Jr., and Ehrenspeck, H.E., eds., 1989, Geologic map of the Casmalia and Orcutt quadrangles, Santa Barbara County, California: Dibblee Geological Foundation, Map DF-24, scale 1:24000.

Dibblee, T.W., Jr., and Ehrenspeck, H.E., eds., 1993a, Geologic map of the Los Alamos quadrangle, Santa Barbara County, California: Dibblee Geological Foundation, Map DF-46, scale 1:24000.

Dibblee, T.W., Jr., and Ehrenspeck, H.E., eds., 1993b, Geologic map of the Zaca Creek quadrangle, Santa Barbara County, California: Dibblee Geological Foundation, Map DF-45, scale 1:24000.

Dibblee, T.W., Jr., Ehrenspeck, H.E., and Bartlett, W.L., eds., 1994a, Geologic map of the Sisquoc quadrangle, Santa Barbara County, California: Dibblee Geological Foundation, Map DF-53, scale 1:24000.

Dibblee, T.W., Jr., Ehrenspeck, H.E., and Bartlett, W.L., eds., 1994b Geologic map of the Foxen Canyon quadrangle, Santa Barbara County, California: Dibblee Geological Foundation, Map DF-54, scale 1:24000.

Donahue, D.J., Linick, T.W., and Jull, A.J.T., 1990, Isotope-ratio and background corrections for accelerator mass spectrometry radiocarbon measurements: Radiocarbon, v. 32, no. 2, p. 135-142. [Available at https://doi.org/10.1017/S0033822200040121.]

Dynamic Graphics, Inc., 2021, EarthVision, accessed November 18, 2021, at https://www.dgi.com/earthvisionsoftware-for-3d-modeling-and-visualization/.

Ely, C.P., Cromwell, G., Sweetkind, D.S., Larsen, J.D. Kohel, C.A., and O'Leary, D.R., 2022, Data release of hydrogeologic data from the San Antonio Creek Valley watershed, Santa Barbara County, California; U.S. Geological Survey data release. [Available at https://doi.org/10.5066/P9AD7DL8.]

Epstein, S., and Mayeda, T.K., 1953, Variation of 180 content of waters from natural sources: Geochimica et Cosmochimica Acta, v. 4, no. 5, p. 213-224. [Available at https://doi.org/10.1016/0016-7037(53)90051-9.]
Faunt, C.C., Belitz, K., and Hanson, R.H., 2010, Development of a three-dimensional model of sedimentary texture in valley-fill deposits of Central Valley, California, USA: Hydrogeology Journal, v. 18, no. 3, p. 625-649. [Available at https://doi.org/10.1007/s10040-009-0539-7.]

Fishman, M.J., 1993, Methods of analysis by the U.S. Geological Survey National Water Quality Laboratory-Determination of inorganic and organic constituents in water and fluvial sediments: U.S. Geological Survey Open-File Report 93-125, 217 p. [Available at https://doi.org/10.3133/ofr93125.]

Fishman, M.J., and Friedman, L.C., 1989, Methods for determination of inorganic substances in water and fluvial sediments: U.S. Geological Survey Techniques of Water-Resources Investigations, book 5, chap. A1, 545 p. [Available at https://pubs.er.usgs.gov/publication/twri05A1.]

Fournier, R.O., and Thompson, J.M., 1980, The recharge area for the Coso, California-Geothermal system deduced from $\delta \mathrm{D}$ and $\delta 18 \mathrm{O}$ in thermal and nonthermal waters in the region: U.S. Geological Survey Open-File Report 80-454, 27 p. [Available at https://doi.org/10.3133/ofr80454.]

Garbarino, J.R., 1999, Methods of analysis by the U.S. Geological Survey National Water Quality Laboratory-Determination of dissolved arsenic, boron, lithium, selenium, strontium, thallium, and vanadium using inductively coupled plasma-mass spectrometry: U.S. Geological Survey Open-File Report 99-093, 31 p. [Available at https://doi.org/10.3133/ofr9993.]

Garbarino, J.R., Kanagy, L.K., and Cree, M.E., 2005, Determination of elements in natural-water, biota, sediment and soil samples using collision/reaction cell inductively coupled plasma-mass spectrometry: U.S. Geological Survey Techniques and Methods, book 5, chap. B1, 88 p. [Available at https://pubs.usgs.gov/tm/2006/tm5b1/PDF/TM5-B1.pdf.]

Gagnon, A.R., and Jones, G.A., 1993, AMS-graphite target production methods at the Woods Hole Oceanographic Institution during 1986-1991: Radiocarbon, v. 35, no. 2, p. 301-310. [Available at https://doi.org/10.1017/S0033822200064985.]

Gibbs, D., 2006, 2005 Santa Barbara County groundwater report: Santa Barbara County Public Works Department Water Resources Division, 102 p. [Available at http://www.countyofsb.org/uploadedFiles/pwd/Content/ Water/WaterAgency/2005\%20groundwater\%20report4.pdf.]

Gibbs, D., 2009, 2008 Santa Barbara County groundwater report: Santa Barbara County Public Works Department Water Resources Division, 112 p. [Available at http://www.countyofsb.org/uploadedFiles/pwd/Content/ Water/WaterAgency/2008\%20groundwater $\% 20$ report $\% 2$ 0FINAL.pdf.] 
Gonfiantini, R., 1978, Standards for stable isotope measurements in natural compounds: Nature, v. 271, p. 534-536. [Available at https://doi.org/10.1038/271534a0.]

Greene, E.A., and Shapiro, A.M., 1998, AIRSLUG-A FORTRAN program for the computation of type curves to estimate storativity from prematurely terminated air-pressurized slug tests: Ground Water, v. 36, no. 2, p. 373-376. [Available at https://doi.org/10.1111/j.1745-6584.1998.tb01103.x.]

Halford, K.J., and Kuniansky, E.L., 2002, Documentation of spreadsheets for the analysis of aquifer-test and slug-test data (version 1.2): U.S. Geological Survey Open-File Report 02-197, 61 p. [Available at https://doi.org/10.3133/ofr02197.]

Helsel, D.R., and Hirsch, R.M., 2002. Statistical methods in water resources: U.S. Geological Survey Techniques of Water-Resources Investigations, book 4, chap. A3, 522 p., accessed July 2, 2020, at https://doi.org/10.3133/twri04A3.

Hem, J.D., 1992, Study and interpretation of the chemical characteristics of natural water (3d ed.): U.S. Geological Survey Water-Supply Paper 2254, 263 p., 3 plates. [Available at https://doi.org/10.3133/wsp2254.]

Hutchinson, C.B., 1980, Appraisal of groundwater resources in the San Antonio Creek Valley, Santa Barbara County, California: U.S. Geological Survey Open-File Report 80-750, 48 p. [Available at https://doi.org/10.3133/ofr80750.]

International Atomic Energy Agency, 1981, Stable isotope hydrology - Deuterium and oxygen-18 in the water cycle: Vienna, Austria, IAEA Technical Reports Series No. 210, 339 p. [Available at http://www-naweb.iaea.org/napc/ih/ documents/IAEA\%20Monographs/TRS\%20210\%20Stable \%20Isotope\%20Hydrology1981.pdf.]

Issacs, C.M., 1992, Preliminary petroleum geology background and well data for oil samples in the Cooperative Monterey Organic Geochemistry Study, Santa Maria and Santa Barbara-Ventura Basins, California: U.S. Geological Survey Open-File Report 92-539-F, 40 p. [Available at https://doi.org/10.3133/ofr92539F.]

Izbicki, J.A., and Michel, R.L., 2003, Movement and age of ground water in the western part of the Mojave Desert, Southern California, USA: U.S. Geological Survey Water-Resources Investigations Report 03-4314, 35 p. [Available at https://pubs.usgs.gov/wri/wrir034314/wrir034314.pdf.]
Izbicki, J.A., Michel, R.L., and Martin, P., 1992, 3H and $14 \mathrm{C}$ as tracers of ground-water recharge, in Engman, T., ed., Saving a threatened resource-In search of solutions, Baltimore, Maryland, August 2-6, 1992, Proceedings: New York, American Society of Civil Engineers, IR Div/ACSE, p. 122-127.

Jenkins, O.P., ed., 1943, Geologic formations and economic development of the oil and gas fields of California: California Division of Mines Bulletin 118, 773 p.

Jennings, C.W., 2010, with modifications by Gutierrez, C., Bryant, W., Saucedo, G., and Wills, C., Geologic map of California: California Geological Survey, Geologic Data Map No. 2, scale 1:750,000. [Available at https://maps.conservation.ca.gov/cgs/gmc/.]

Jurgens, B.C., McMahon, P.B., Chapelle, F.H., and Eberts, S.M., 2009, An Excel workbook for identifying redox processes in ground water: U.S. Geological Survey Open-File Report 2009-1004, 8 p. [Available at https://doi.org/10.3133/ofr20091004.]

Kalin, R.M., 2000, Radiocarbon dating of groundwater systems, in Cook, P.G., and Herczeg, A.L., eds., Environmental tracers in subsurface hydrology: Boston, Mass., Kluwer Academic Publishers, p. 111-144. [Available at https://doi.org/10.1007/978-1-4615-4557-6_4.]

Lafreniere, G.F., and French, J.J., 1968, Ground-water resources of the Santa Ynez upland ground-water basin, Santa Barbara County, California: U.S. Geological Survey Open-File Report 68-163, accessed June 20, 2020, at https://doi.org/10.3133/ofr68163.

LANDFIRE, 2014, Existing vegetation type layer, LANDFIRE 1.4.0: U.S. Geological Survey, accessed September 11, 2018, at https://landfire.cr.usgs.gov/getdata.php.

Lindberg, R.D., and Runnels, D.D., 1984, Ground water redox reactions-An analysis of equilibrium state applied to eh measurements and geochemical modeling: Science, v. 225 , no. 4665 , p. $925-927$, accessed July 26 , 2021, at https://doi.org/10.1126/science.225.4665.925.

Maidment, D.R., 1993, Handbook of hydrology: New York, NY, McGraw-Hill, Inc., 750 p.

Mallory, M.J., 1980, Potential effects of increased ground-water pumpage on Barka Slough, San Antonio Creek Valley, Santa Barbara County, California: U.S. Geological Survey Water-Resources Investigation Report 80-95. [Available at https://doi.org/10.3133/wri8095.] 
Martin, P., 1985, Development and calibration of a two-dimensional digital model for the analysis of the ground-water flow system in the San Antonio Creek Valley, Santa Barbara County, California: U.S. Geological Survey Water-Resources Investigations Report 84-4340. [Available at https://doi.org/10.3133/wri844340.]

Mathany, T.M., Burton, C.A., Land, M., and Belitz, K., 2010, Groundwater-quality data in the South Coast Range - Coastal study unit, 2008-Results from the California GAMA program: U.S. Geological Survey Data Series 504, 106 p., accessed July 3, 2020, at https://doi.org/10.3133/ds504.

McCarlson, A.J., Johnson, J.C., Marcusa, J.A., Qi, S.L., Davis, T.A., and Rosecrans, C.Z., 2021, Water chemistry data for samples collected at groundwater sites near the Orcutt Oil Field, September 2017-March 2018, Santa Barbara County, California: U.S. Geologic Survey data release. [Available at https://doi.org/10.5066/P90RCZ3T.]

McMahon, P.B., and Chapelle, F.H., 2008, Redox processes and water quality of selected principal aquifer systems: Ground Water, v. 46, no. 2, p. 259-271. [Available at https://doi.org/10.1111/j.1745-6584.2007.00385.x.]

Michel, R.L., 1976, Tritium inventories of the world oceans and their implications: Nature, v. 263, no. 5573, p. 103-106. [Available at https://doi.org/10.1038/263103a0.]

Michel, R.L., 2005, Tritium in the hydrologic cycle, in Aggarwal, P.K., Gat, J.R., and Froehlich, K.F.O., eds., Isotopes in the water cycle-Past, present, and future of a developing science: Dordrecht, Springer, p. 53-66. [Available at https://doi.org/10.1007/1-4020-3023-1_5.]

Miller, G.A., 1976, Ground-water resources in the Lompoc area, Santa Barbara County, California: U.S. Geological Survey Open-File Report 76-183, 78 p. [Available at https://doi.org/10.3133/ofr76183.]

Miller, K.C., and Meltzer, A.S., 2002, Structure and tectonics of the central offshore Santa Maria and Santa Lucia basins, California—-Results from the PG\&E/EDGE Seismic Reflection Survey, in Keller, M.A., ed., Evolution of sedimentary basins/onshore oil and gas investigationsSanta Maria Province: U.S. Geological Survey Bulletin 1995-Z, 12 p., 4 plates.

Mills, W.R., 2009, Borrego Water District integrated water Resources management plan final report: 128 p., accessed May 20, 2021, at https://borregowd.org/wp-content/uploads/ 2020/05/Borrego-Valley-IWMP-Final-2009.pdf.

Mook, W.G., 1980, The dissolution-exchange model for dating of groundwater with 14C, in Fritz, P., and Fontes, J.C., eds., Handbook of environmental isotopes geochemistry v. 1: Amsterdam, Netherlands, Elsevier, p. 50-74.
Mower, R.W., and Nace, R.L., 1957, Water consumption by water-loving plants in the Malad Valley, Oneida County, Idaho: U.S. Geological Survey Water-Supply Paper 1412, 88 p. [Available at https://pubs.usgs.gov/wsp/1412/report.pdf.]

Muir, K.S., 1964, Geology and ground water of San Antonio Creek Valley, Santa Barbara County, California: U.S. Geological Survey Professional Paper 1664, 53 p. [Available at https://doi.org/10.3133/wsp1664.]

Namson, J., and Davis, T.L., 1990, Late Cenozoic fold and thrust belt of the Southern Coast Ranges and Santa Maria Basin, California: The American Association of Petroleum Geologists Bulletin, v. 74, no. 4, p. 467-492, accessed December 27, 2021, at https://pubs.geoscienceworld.org/ aapgbull/article/74/4/467/38555/Late-Cenozoic-Fold-andThrust-Belt-of-the-Southern.

National Ocean Sciences Accelerator Mass Spectrometry Facility, 2018, General statement of $14 \mathrm{C}$ procedures at the National Ocean Sciences AMS Facility. [Available at https://www2.whoi.edu/site/nosams/general-statement-of14c-procedures/.]

O'Leary, D.R., Izbicki, J.A., and Metzger, L.F., 2015, Sources of high-chloride water and managed aquifer recharge in an alluvial aquifer in California, USA: Hydrogeology Journal, v. 23, no. 7, p. 1515-1533. [Available at https://doi.org/10.1007/s10040-015-1277-7.]

Patton, C.J., and Kryskalla, J.R., 2003, Methods of analysis by the U.S. Geological Survey National Water Quality Laboratory-Evaluation of alkaline persulfate digestion as an alternative to Kjeldahl digestion for determination of total and dissolved nitrogen and phosphorus in water: U.S. Geological Survey Water-Resources Investigations Report 2003-4174, 33 p. [Available at https://pubs.er.usgs.gov/publication/wri034174.]

Patton, C.J., and Kryskalla, J.R., 2011, Colorimetric determination of nitrate plus nitrite in water by enzymatic reduction, automated discrete analyzer methods: U.S. Geological Survey Techniques and Methods, book 5, chap. B8. [Available at https://pubs.usgs.gov/tm/05b08.]

Philip, J.R., 1969, Theory of infiltration: Advances in Hydroscience, v. 5, p. 215-296. [Available at https://doi.org/10.1016/B978-1-4831-9936-8.50010-6.]

Phillips, S.P., and Belitz, K., 1991, Calibration of a texture-based model of a ground-water flow system, western San Joaquin Valley, California: Ground Water, v. 29, p. 702-715. [Available at https://doi.org/10.1111/j.1745-6584.1991.tb00562.x.]

PRISM Climate Group, 2013, 30-year normals: Oregon State University, created September 11, 2013. [Available at https://prism.oregonstate.edu.] 
Ralph, F.M., Coleman, T., Neiman, P.J., Zamora, R.J., and Dettinger, M.D., 2013, Observed impacts of duration and seasonality of atmospheric-river landfalls on soil moisture and runoff in coastal Northern California: Journal of Hydrometeorology, v. 14, no. 2, p. 443-459, accessed July 2, 2020, at https://doi.org/10.1175/JHM-D-12-076.1.

Révész, K., and Coplen, T.B., 2008a, Determination of the $\delta(2 \mathrm{H} / 1 \mathrm{H})$ of water-RSIL lab code 1574 , chap. C1 in Révész, K., and Coplen, T.B., eds., Methods of the Reston Stable Isotope Laboratory: U.S. Geological Survey Techniques and Methods, book 10, chap. C1, 27 p. [Available at https://pubs.er.usgs.gov/publication/tm10C1.]

Révész, K., and Coplen, T.B., 2008b, Determination of the $\delta(180 / 160)$ of water-RSIL lab code 489 , chap. C2 in Révész, K., and Coplen, T.B., eds., Methods of the Reston Stable Isotope Laboratory: U.S. Geological Survey Techniques and Methods, book 10, chap. C2, 28 p. [Available at https://pubs.er.usgs.gov/publication/tm10C2.]

Robinove, C.J., Langford, R.H., and Brookhart, J.W., 1958, Saline-water resources of North Dakota: U.S. Geological Survey Water-Supply Paper 1428, 72 p., 1 plate. [Available at https://pubs.usgs.gov/wsp/1428/report.pdf.]

Santa Barbara County Water Agency, 1977, Adequacy of the groundwater basins, Santa Barbara County: Water Agency Staff report, 267 p., accessed November 18, 2021, at https://www.countyofsb.org/uploadedFiles/pwd/Content/ Water/WaterAgency/Adequacy $\% 20$ of $\% 20$ the $\% 20 \mathrm{GW} \% 20$ Basins\%20of\%20SBC\%201977_sm.pdf.

Santa Barbara County, 2017, 2016 Agricultural field boundaries: accessed October 30, 2018, at https://cosantabarbara.app.box.com/s/jdt95fy 7 gst3 g864919t3ukrorr5xeh9.

Santa Barbara County, 2019, Daily precipitation: Santa Barbara County Public Works Department, accessed March 14, 2019, at http://www.countyofsb.org/pwd/dailyrain.sbc.

Schneider, R.J., Jones, G.A., McNichol, A.P., von Reden, K.F., Elder, K.L., Huang, K., and Kessel, E.D., 1994, Methods for data screening, flagging, and error analysis at the National Ocean Sciences AMS Facility: Nuclear Instruments and Methods in Physics Research, v. 92, no. 1-4, p. 172-175. [Available at https://doi.org/10.1016/0168-583X(94)96000-3.]

Schwertz, F.A., 1950, Rate-indicating Mariotte bottle: Analytical Chemistry, v. 22, no. 12, p. 1511. [Available at https://doi.org/10.1021/ac60048a038.]

Shapiro, A.M., and Greene, E.A., 1995, Interpretation of prematurely terminated air-pressurized slug tests: Groundwater, v. 33, no. 4, p. 539-546. [Available at https://doi.org/10.1111/j.1745-6584.1995.tb00308.x.]
Singer, J.S., and Swarzenski, W.V., 1970, Pumpage and ground-water storage depletion in Cuyama valley, California, 1947-66: U.S. Geological Survey Open-File Report 70-304, 22 p. [Available at https://pubs.er.usgs.gov/publication/ofr70304.]

Stanley, R.G., Johnson, S.Y., Swisher, C.C., III, Mason, M.A., Obradovich, J.D., Cotton, M.L., Filewicz, M.V., and Vork, D.R., 1996, Age of the Lospe Formation (early Miocene) and origin of the Santa Maria Basin, California, in Keller, M.A., ed., Evolution of sedimentary basins/ onshore oil and gas investigations - Santa Maria Province: U.S. Geological Survey Bulletin 1995-M, 37 p. [Available at https://pubs.er.usgs.gov/publication/b1995MNO.]

Stiff, H.A., Jr., 1951, The interpretation of chemical water analysis by means of patterns: Journal of Petroleum Technology, v. 3, no. 10, p. 376-379. [Available at https://doi.org/10.2118/951376-G.]

Sweetkind, D.S., Langenheim, V.E, McDougall-Reid, K., Sorlien, C.C., Demas, S.C., Tennyson, M.E., and Johnson, S.Y., 2021, Geologic and geophysical maps of the Santa Maria and part of the Point Conception $30^{\prime} \times 60^{\prime}$ quadrangles, California: U.S. Geological Survey Scientific Investigations Map 3472, 1 sheet, scale 1:100,000, 58-p. pamphlet.

[Available at https://pubs.er.usgs.gov/publication/sim3472.]

Sweetkind, D.S., Tennyson, M.E., Langenheim, V.E., and Shumaker, L.E., 2010, Digital tabulation of stratigraphic data from oil and gas wells in the Santa Maria Basin, central California coast: U.S. Geological Survey Open-File Report 2010-1129, 11 p., 3 tables. [Available at https://pubs.usgs.gov/of/2010/1129/.]

Sylvester, A.G., and Darrow, A.C., 1979, Structure and neotectonics of the western Santa Ynez fault system in southern California: Tectonophysics, v. 52, no. 1-4, p. 389-405. [Available at https://doi.org/10.1016/0040-1951(79)90253-1.]

Tanaka, M., Girard, G., Davis, R., Peuto, A., and Bignell, N., 2001, Recommended table for the density of water between $0{ }^{\circ} \mathrm{C}$ and $40{ }^{\circ} \mathrm{C}$ based on recent experimental reports: Metrologia, v. 38, p. 301-309. [Available at https://doi.org/10.1088/0026-1394/38/4/3.]

Teague, N.F., Izbicki, J.A., Borchers, J., Kulongoski, J.T., and Jurgens, B.C., 2018, Hydrogeologic controls and geochemical indicators of groundwater movement in the Niles Cone and southern East Bay Plain groundwater subbasins, Alameda County, California (ver. 1.1, February 2019): U.S. Geological Survey Scientific Investigations Report 2018-5003, 62 p. [Available at https://doi.org/10.3133/sir20185003.] 
Tennyson, M.E., 1992, Preliminary digital geologic map of the Santa Maria 30' x 60' Quadrangle, California: U.S. Geological Survey Open-File Report 92-189, 9 p. [Available at https://pubs.er.usgs.gov/publication/ofr92189.]

Tennyson, M.E., Beeman, W.R., and Urban, S.B., 1995, Preliminary digital geologic map of the Santa Maria $30^{\prime}$ x 60' Quadrangle, California, in ARC/INFO, with exploration well locations and subsurface formation depths: U.S. Geological Survey Open-File Report 95-25, 2 p. [Available at https://pubs.er.usgs.gov/publication/ofr9525.]

Tetra Tech, Inc., 2012, Final historical water balance of the San Antonio Groundwater Basin: Pasadena, California, Tetra Tech, Inc., prepared for Vandenberg Air Force Base, California, $96 \mathrm{p}$.

Tetra Tech, Inc., 2013, Final groundwater model of the San Antonio Basin: Tetra Tech, Inc., Santa Maria, California, 129 p., accessed April 15, 2020.

Thatcher, L.L., Janzer, V.J., and Edwards, K.W., 1977, Methods for determination of radioactive substances in water and fluvial sediments: U.S. Geological Survey Techniques of Water Resources Investigations, book 5, chap. A5, 95 p. [Available at https://pubs.water.usgs.gov/twri5a5.]

Umari, A.M.J., Martin, P., Schroeder, R.A., Duell, L.F.W., Jr., and Fay, R.G., 1995, Potential for ground-water contamination from movement of wastewater through the unsaturated zone, upper Mojave River Basin, California: U.S. Geological Survey Water-Resources Investigations Report 93-4137, 83 p.

Upson, J.E., and Thomasson, H.G., Jr., 1951, Geology and water resources of the Santa Ynez River basin, Santa Barbara County, California: U.S. Geological Survey Water Supply Paper 1107, accessed June 20, 2020, at https://pubs.er.usgs.gov/publication/wsp1107.

U.S. Census Bureau, 2000, Decennial census of population and housing - by decade, 2000: accessed September 11, 2019, at https://www.census.gov/programs-surveys/ decennial-census/decade.2000.html.

U.S. Census Bureau, 2010, Decennial census of population and housing-By decade, 2010: accessed September 11, 2019, at https://www.census.gov/programs-surveys/ decennial-census/decade.2010.html.

U.S. Census Bureau, 2020, Decennial census of population and housing - By decade, 2020: accessed December 11, 2021, at https://www.census.gov/programs-surveys/ decennial-census/decade.2020.html.
U.S. Environmental Protection Agency, 2006, 2006 Edition of the drinking water standards and health advisories: Office of Water EPA 822-R-06-013. [Available at https://nepis.epa.gov/Exe/ZyPDF.cgi/P1004X78.PDF? Dockey=P1004X78.PDF.]

U.S. Environmental Protection Agency, 2017a, Secondary drinking water standards: U.S. Environmental Protection Agency, accessed September 20, 2019, at https://www.epa.gov/sdwa/secondary-drinking-waterstandards-guidance-nuisance-chemicals.

U.S. Environmental Protection Agency, 2017b, National primary drinking water regulations: U.S. Environmental Protection Agency, accessed September 20, 2019, at https://www.epa.gov/ground-water-and-drinking-water/ national-primary-drinking-water-regulations.

U.S. Geological Survey, 2013, National Elevation Dataset (USGS NED n35w121 1/3 arc-second $20131 \times 1$ degree ArcGrid (published 20131101)), accessed March 8, 2016, at https://www.usgs.gov/core-science-systems/nationalgeospatial-program/national-map.

U.S. Geological Survey, 2016, National Hydrography Dataset (ver. USGS Hydrography Dataset Best Resolution (NHD) for Hydrologic Unit (HU) 8-18060009 (published 20161230)): accessed January 19, 2017, at https://www.usgs.gov/core-science-systems/ngp/nationalhydrography/access-national-hydrography-products.

U.S. Geological Survey, 2018, USGS GeoLog Locator: accessed September 30, 2018, at https://doi.org/10.5066/F7X63KT0.

U.S. Geological Survey, 2020, Oxidation/reduction (redox): U.S. Geological Survey website, accessed July 23, 2020, at https://www.usgs.gov/mission-areas/water-resources/ science/oxidationreduction-redox?qt-science_center_ objects $=0 \# q t-s c i e n c e$ _center_objects.

U.S. Geological Survey, 2021, USGS water data for the Nation: U.S. Geological Survey National Water Information System database, accessed September 8, 2021, at https://doi.org/10.5066/F7P55KJN.

U.S. Geological Survey and California Geological Survey, 2019, Quaternary fault and fold database of the United States: U.S. Geological Survey, accessed October 21, 2019, at https://www.usgs.gov/natural-hazards/earthquakehazards/faults.

U.S. Geological Survey, variously dated, National field manual for the collection of water-quality data: U.S. Geological Survey Techniques of Water-Resources Investigations, book 9, chaps. A1-A9. [Available at https://pubs.water.usgs.gov/twri9A.] 
Viessman, W., Jr., and Lewis, G.L., 2003, Introduction to hydrology (5th ed.): Upper Saddle River, N.J., Prentice Hall, 612 p.

Vogel, J.S., Nelson, D.E., and Southon, J.R., 1987, ${ }^{14} \mathrm{C}$ background levels in an accelerator mass spectrometry system: Radiocarbon, v. 29, no. 3, p. 323-333. [Available at https://doi.org/10.1017/S0033822200043733.]

Wahl, K.L., and Wahl, T.L., 1995. Determining the flow of comal springs at New Braunfels, Texas, in Proceedings of Texas Water'95, August 16-17, 1995, San Antonio, Texas: American Society of Civil Engineers, p. 77-86, accessed July 2, 2020, at https:/www.usbr.gov/tsc/techreferences/ hydraulics_lab/pubs/PAP/PAP-0708.pdf.

Western Regional Climate Center, 2020, RAWS sites: accessed December 10, 2020, at https://wrcc.dri.edu/wraws/scaF.html.

White, I., and Sully, M.J., 1987, Macroscopic and microscopic capillary length and time scales from field infiltration: Water Resources Research, v. 23, p. 1514-1522. [Available at https://doi.org/10.1029/WR023i008p01514.]

Wilde, F.D., variously dated, Field measurements: U.S. Geological Survey Techniques of Water-Resources Investigations, book 9, chap. A6, with sec. 6.0-6.8. [Available at http://pubs.water.usgs.gov/twri9A6.]
Wooding, R.A., 1968, Steady infiltration from a shallow circular pond: Water Resources Research, v. 4, no. 6, p. 1259-1273. [Available at https://doi.org/10.1029/WR004i006p01259.]

Woodring, W.P., and Bramlette, M.N., 1950, Geology and paleontology of the Santa Maria district, California: U.S. Geological Survey Professional Paper 222, 185 p., 23 pls. [Available at https://doi.org/10.3133/pp222.]

Woolfenden, L.R., Engott, J.A., Larsen, J.D., and Cromwell, G., 2022, Simulation of groundwater and surface-water resources of the San Antonio Creek Valley watershed, Santa Barbara County, California: U.S. Geological Survey Scientific Investigations Report 2021-5139, 76 p. [Available at https://doi.org/10.3133/sir20215139.]

Zernitz, E.R., 1932, Drainage patterns and their significance: The Journal of Geology, v. 40, no. 6, p. 498-521, accessed July 2, 2020, at https://doi.org/10.1086/623976.

Zhu, Y., and Newell, R.E., 1998, A proposed algorithm for moisture fluxes from atmospheric rivers: American Meteorological Society, v. 126, no. 3, p. 725-735, accessed July 2, 2020, at https://doi.org/10.1175/1520-0493(1998)12 $6<0725$ :APAFMF $>2.0 . \mathrm{CO} ; 2$. 


\section{Appendix 1. Supplementary Information on Population, Streambed Electrical Resistivity Instruments, and U.S. Geological Survey Monitoring Wells}

\section{Population}

Reported population for the town of Los Alamos, California, were compiled for 1935 from Tetra Tech, Inc. (2012), 1977 from Hutchinson (1980, citing Los Alamos Community Services District, oral commun., 1977), and for 2000, 2010, and 2020 from the U.S. Census Bureau (2000, 2010, 2020). The population of the town of Los Alamos for years without reported values was estimated in this study by calculating the average annual change in population for years between reported values and adding (or subtracting) that average annual value from a known population year. Note, table 1.1 only lists population values from 1948 to 2018 .

The average annual change in population in the town of Los Alamos between 1935 (population 140) and 1977 (population 900) was 18 people per year (p/yr). The annual population during 1936-76 was therefore estimated by adding 18 people each year from a starting value of 140 . The average annual change in population between 1977 (population 900 ) and 2000 (population 1,372) was $21 \mathrm{p} / \mathrm{yr}$. The annual population during 1978-99 was therefore estimated by adding 21 people each year from a starting value of 900 . The average annual change in population between 2000 (population 1,372) and 2010 (population 1,890) was $52 \mathrm{p} / \mathrm{yr}$. The annual population during 2001-09 was therefore estimated by adding 52 people each year from a starting value of 1,372 . The average annual change in population between 2010 (population 1,890) and 2020 (population 1,839) was negative $5 \mathrm{p} / \mathrm{yr}$. The annual population during 2011-19 was therefore estimated by subtracting 5 people each year from a starting value of 1,890 .

The total population of the SACVW includes residents who live in the town of Los Alamos and rural residents who live beyond the town boundaries. The total population of the SACVW was estimated for 2000, 2010, and 2020 from geospatial census block data (U.S. Census Bureau, 2000, 2010, 2020) using Esri ArcGIS version 10.7.1 geographic information systems software. The population values of geospatial census blocks located entirely within the SACVW were retained, whereas population estimates of geospatial census blocks located partially within the SACVW were reduced by the percentage of the census block area within the boundary. The resulting population estimates of the SACVW for 2000, 2010, and 2020 were 1,953, 2,790, and 2,183 people, respectively.

On average, the estimated population of the SACVW was 1.4 times greater than the reported population of the town of Los Alamos (1.42 times greater in 2000, 1.48 times greater in 2010, and 1.18 times greater in 2020). For simplicity, the average value of 1.4 times the population of Los Alamos was used in this report to estimate the population of the SACVW for 1948-2018; therefore the population of the SACVW was assumed to be 1.4 times greater than the reported or estimated population of the town of Los Alamos (table 1.1). 
Table 1.1. Estimated population of the town of Los Alamos and the San Antonio Creek Valley watershed during calendar years 1948-2018, San Antonio Creek Valley watershed, Santa Barbara County, California.

[Rural residents are calculated as the difference between the populations of the San Antonio Creek Valley watershed and the town of Los Alamos.]

\begin{tabular}{|c|c|c|c|}
\hline \multirow{2}{*}{$\begin{array}{l}\text { Calendar } \\
\text { year }\end{array}$} & \multicolumn{3}{|c|}{ Population } \\
\hline & $\begin{array}{c}\text { Town of } \\
\text { Los Alamos }\end{array}$ & $\begin{array}{c}\text { San Antonio } \\
\text { Valley watershed }\end{array}$ & $\begin{array}{c}\text { Rural } \\
\text { residents }\end{array}$ \\
\hline 1948 & 378 & 529 & 151 \\
\hline 1949 & 396 & 554 & 158 \\
\hline 1950 & 414 & 580 & 166 \\
\hline 1951 & 432 & 605 & 173 \\
\hline 1952 & 450 & 630 & 180 \\
\hline 1953 & 468 & 655 & 187 \\
\hline 1954 & 486 & 680 & 194 \\
\hline 1955 & 504 & 706 & 202 \\
\hline 1956 & 522 & 731 & 209 \\
\hline 1957 & 540 & 756 & 216 \\
\hline 1958 & 558 & 781 & 223 \\
\hline 1959 & 576 & 806 & 230 \\
\hline 1960 & 594 & 832 & 238 \\
\hline 1961 & 612 & 857 & 245 \\
\hline 1962 & 630 & 882 & 252 \\
\hline 1963 & 648 & 907 & 259 \\
\hline 1964 & 666 & 932 & 266 \\
\hline 1965 & 684 & 958 & 274 \\
\hline 1966 & 702 & 983 & 281 \\
\hline 1967 & 720 & 1,008 & 288 \\
\hline 1968 & 738 & 1,033 & 295 \\
\hline 1969 & 756 & 1,058 & 302 \\
\hline 1970 & 774 & 1,084 & 310 \\
\hline 1971 & 792 & 1,109 & 317 \\
\hline 1972 & 810 & 1,134 & 324 \\
\hline 1973 & 828 & 1,159 & 331 \\
\hline 1974 & 846 & 1,184 & 338 \\
\hline 1975 & 864 & 1,210 & 346 \\
\hline 1976 & 882 & 1,235 & 353 \\
\hline 1977 & 900 & 1,260 & 360 \\
\hline 1978 & 921 & 1,289 & 368 \\
\hline 1979 & 942 & 1,319 & 377 \\
\hline 1980 & 963 & 1,348 & 385 \\
\hline 1981 & 984 & 1,378 & 394 \\
\hline 1982 & 1,005 & 1,407 & 402 \\
\hline 1983 & 1,026 & 1,436 & 410 \\
\hline 1984 & 1,047 & 1,466 & 419 \\
\hline
\end{tabular}

Table 1.1. Estimated population of the town of Los Alamos and the San Antonio Creek Valley watershed during calendar years 1948-2018, San Antonio Creek Valley watershed, Santa Barbara County, California.-Continued

[Rural residents are calculated as the difference between the populations of the San Antonio Creek Valley watershed and the town of Los Alamos.]

\begin{tabular}{|c|c|c|c|}
\hline \multirow{2}{*}{$\begin{array}{l}\text { Calendar } \\
\text { year }\end{array}$} & \multicolumn{3}{|c|}{ Population } \\
\hline & $\begin{array}{c}\text { Town of } \\
\text { Los Alamos }\end{array}$ & $\begin{array}{c}\text { San Antonio } \\
\text { Valley watershed }\end{array}$ & $\begin{array}{c}\text { Rural } \\
\text { residents }\end{array}$ \\
\hline 1985 & 1,068 & 1,495 & 427 \\
\hline 1986 & 1,089 & 1,525 & 436 \\
\hline 1987 & 1,110 & 1,554 & 444 \\
\hline 1988 & 1,131 & 1,583 & 452 \\
\hline 1989 & 1,152 & 1,613 & 461 \\
\hline 1990 & 1,173 & 1,642 & 469 \\
\hline 1991 & 1,194 & 1,672 & 478 \\
\hline 1992 & 1,215 & 1,701 & 486 \\
\hline 1993 & 1,236 & 1,730 & 494 \\
\hline 1994 & 1,257 & 1,760 & 503 \\
\hline 1995 & 1,278 & 1,789 & 511 \\
\hline 1996 & 1,299 & 1,819 & 520 \\
\hline 1997 & 1,320 & 1,848 & 528 \\
\hline 1998 & 1,341 & 1,877 & 536 \\
\hline 1999 & 1,362 & 1,907 & 545 \\
\hline 2000 & 1,372 & 1,921 & 549 \\
\hline 2001 & 1,424 & 1,994 & 570 \\
\hline 2002 & 1,476 & 2,066 & 590 \\
\hline 2003 & 1,528 & 2,139 & 611 \\
\hline 2004 & 1,580 & 2,212 & 632 \\
\hline 2005 & 1,632 & 2,285 & 653 \\
\hline 2006 & 1,684 & 2,358 & 674 \\
\hline 2007 & 1,736 & 2,430 & 694 \\
\hline 2008 & 1,788 & 2,503 & 715 \\
\hline 2009 & 1,840 & 2,576 & 736 \\
\hline 2010 & 1,890 & 2,646 & 756 \\
\hline 2011 & 1,885 & 2,639 & 754 \\
\hline 2012 & 1,880 & 2,632 & 752 \\
\hline 2013 & 1,875 & 2,625 & 750 \\
\hline 2014 & 1,870 & 2,618 & 748 \\
\hline 2015 & 1,865 & 2,611 & 746 \\
\hline 2016 & 1,860 & 2,604 & 744 \\
\hline 2017 & 1,855 & 2,597 & 742 \\
\hline 2018 & 1,850 & 2,590 & 740 \\
\hline 2019 & 1,845 & 2,583 & 738 \\
\hline 2020 & 1,839 & 2,575 & 736 \\
\hline
\end{tabular}




\section{Streambed Electrical Resistivity Instruments}

Various methods have been developed to monitor streamflow in intermittent and ephemeral streams. The use of traditional methods, such as semi-permanent streamgaging stations, to monitor streamflow in intermittent streams is complicated by the highly variable nature of intermittent streams, which are typically characterized by variable flows of short duration, and variable bed morphologies (Tadayon and others, 2001).

Streambed electrical resistivity sensors (SERS) were created by repurposing commercial temperature sensors to record electrical conductivity; this included removing and replacing the sensor thermistor with water-contact electrodes (Blasch and others, 2002). A total of 20 SERS was created by modifying Onset HOBO Water Temp Pro v2 (Model U22-001, ONSET Computer Corp, Mourne MA, USA) probes according to the methods of Blasch and others (2002). Each SERS instrument was deployed inside a metal box, 4 inches wide by 4 inches long, by 10 inches tall, with the bottom of the box level with the streambed (fig. 1.1). Stream Temperature, Intermittency, and Conductivity loggers (STICs) were created by repurposing commercial optical sensors so that a temperature and conductivity signal could be recorded (Chapin and others, 2014). Five STICs were created by modifying ONSET HOBO Pendant temperature and light data loggers (Model UA-002-64, ONSET Computer Corp, Mourne MA, USA) according to the methods of Chapin and others (2014). Each STIC instrument was housed in a protective casing created from 3/4-inch polyvinyl chloride (PVC) unions and secured to the streambed using steel stakes. The SERS and STICs logged data in 5 to 15 -minute intervals; site visits to download data and maintain the sensors occurred about every six weeks while the sensors were deployed.
These instruments function as simple two-pole conductivity meters. Electrical conductivity is the inverse of electrical resistance. The electrical resistance of a porous medium is the sum of the bulk resistance of the medium material and the contact resistance at each electrode and medium interface. Electrical resistance refers to a material's ability to inhibit an electrical current, whereas electrical conductance refers to a material's ability to conduct an electrical current. Because the electrical conductivity of air is practically zero, the instruments record a minimum value when the contact electrodes are exposed to air. When the contact electrodes are submerged, contact resistance is at a minimum, and the maximum conductivity values are recorded (Blasch and others, 2002). In intermittent streams where these instruments are deployed, sediment deposition and changes in channel morphology are common (Tadayon and others, 2001; Chapin and others, 2014). If buried, contact between the electrodes and sediments will lower the contact resistance such that a circuit is completed and record conductivity values. Intermediate conductivity values can correspond to periods when the instruments were buried at various degrees of saturation. By establishing percent relative conductance thresholds, stream intermittency can be determined (Blasch and others, 2002; Chapin and others, 2014).

The instruments performed best at sites located in stream channel sections with enough energy to flush away sediment but not where large pieces of debris could be mobilized. Sites in high-energy channel sections were likely to have instruments be lost or damaged during storm events. Instruments at sites in low-energy channel sections were often subjected to repeated sedimentation and burial; repeated burial in saturated sediments likely degraded instrument signal quality over time, resulting in noisy datasets. 
$\boldsymbol{A}$

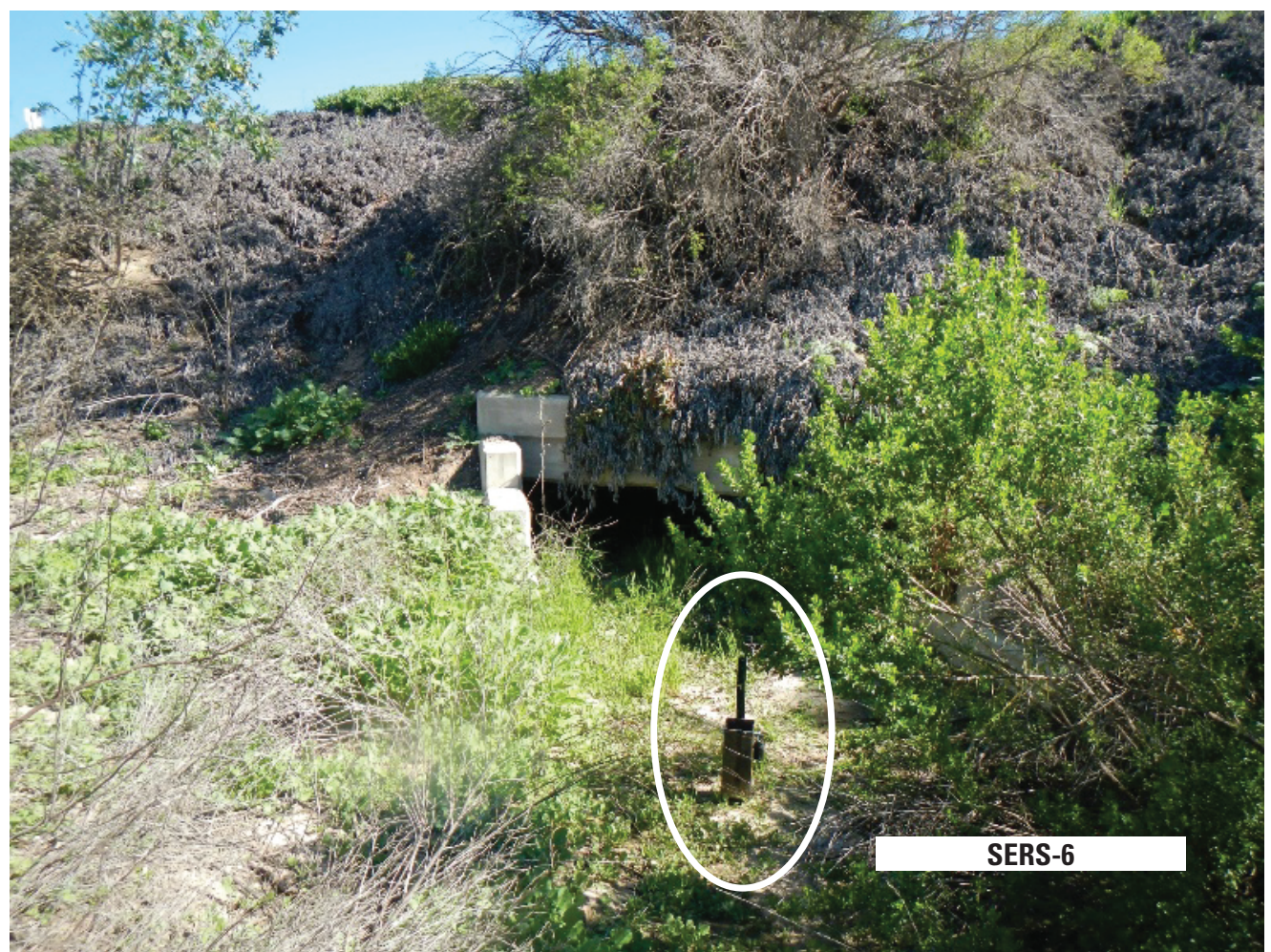

Photograph by David O'Leary, U.S. Geological Survey

B

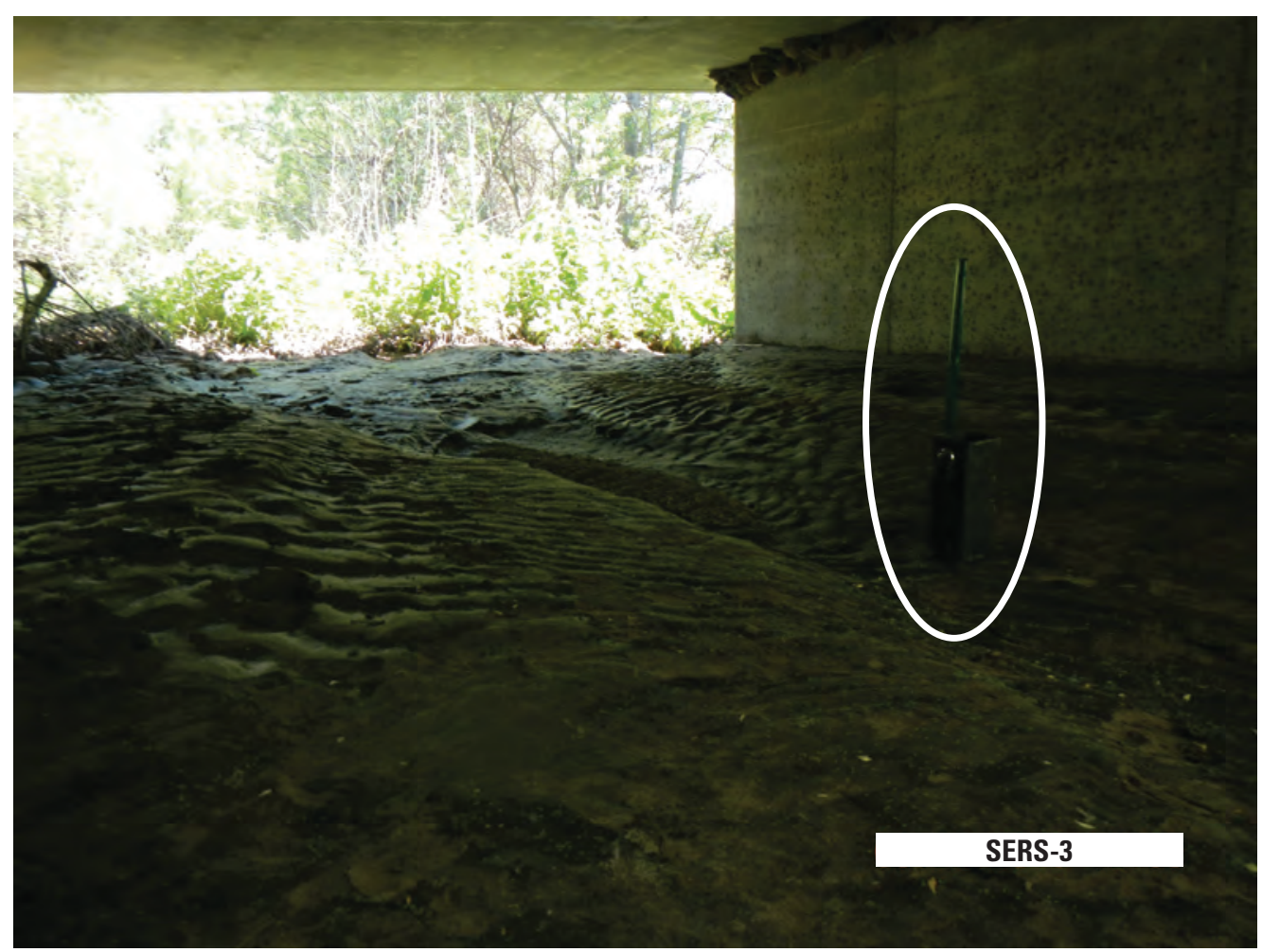

Photograph by David O'Leary, U.S. Geological Survey

Figure 1.1. Photographs of streambed electrical resistivity sensor (SERS) instrument sites, $A$, SERS-6, and $B$, SERS-3, San Antonio Creek Valley watershed, Santa Barbara County, California. 


\section{Drilling and Construction of U.S. Geological Survey Monitoring-Well Sites}

Monitoring wells were installed at eight sites across the San Antonio Creek Valley Watershed (SACVW) during 2015-16 (fig. 16) to collect geographically distinct and depth-dependent hydrogeologic and hydrologic data. A total of 16 independent monitoring wells were established across the 8 sites: 2 of the sites each contain 4 wells completed at different depths and a single shallow well, and the remaining 6 sites contain a single shallow well (table 1.2). All wells were developed to obtain representative measurements of aquifer-system conditions and were subsequently used for additional data collection.

\section{Well Drilling and Construction}

Two multiple-depth, monitoring-well sites (MMWS; SACR and SACC; table 1.2; U.S. Geological Survey, 2018, 2021) were drilled along the main east-west axis of the SACVW on the valley floor where basin sediments were thickest (fig. 17). Each MMWS consists of a deep borehole (greater than about 700 feet [ft] deep; U.S. Geological Survey, 2018) with four monitoring wells (or piezometers) completed at different depths below land surface (table 1.2), and an adjacent shallow borehole (about $100 \mathrm{ft}$ deep; U.S. Geological Survey, 2018) with a single monitoring well completed at the bottom of the borehole. All five monitoring wells in each MMWS were spaced at depths about 200 feet apart to provide a vertical discretization of the aquifer system. Each MMWS provides detailed geologic and geophysical data of the aquifer system and information on the water-bearing properties of the aquifer materials.

The deep MMWS boreholes were drilled using a mud-rotary method, and the shallow MMWS boreholes were drilled using a hollow-stem auger method. Multiple-depth, monitoring-well site locations were chosen where previous depth-dependent lithologic, borehole-geophysical, water-level, and water-quality data were unavailable or limited. When using mud-rotary drilling methods, the initial $20 \mathrm{ft}$ of the borehole was drilled to a 20 -inch diameter, and surface casing was installed and cemented to prevent undermining during the drilling of the remainder of the hole. A full suite of borehole-geophysical logs was collected for each deep borehole before wells were constructed (fig. 18). Electromagnetic induction borehole-geophysical logs were collected at each shallow borehole. Lithologic and geophysical

Table 1.2. Locations of U.S. Geological Survey (USGS) single- and multiple-well monitoring sites and well-construction information, San Antonio Creek Valley watershed, Santa Barbara County, California.

[Type and purpose of well: MMWS, multiple-depth monitoring-well site; SMWS, single-depth monitoring-well site. Type of seal: G, grout; GC, grout and bentonite chips; GP, grout and bentonite pellets; GPC, grout bentonite pellets and bentonite chips; CGr, bentonite chips and granular bentonite. Abbreviations: NAD 83, North American Datum of 1983; ft, feet; NAVD 88, North American Vertical Datum of 1988; BLSD, below land surface datum; mm/dd/yyyy, month/ day/year]

\begin{tabular}{|c|c|c|c|c|c|c|}
\hline $\begin{array}{l}\text { Well } \\
\text { Name }\end{array}$ & $\begin{array}{c}\text { USGS } \\
\text { station number }\end{array}$ & $\begin{array}{c}\text { USGS } \\
\text { station name }\end{array}$ & $\begin{array}{c}\text { State } \\
\text { well number }\end{array}$ & $\begin{array}{l}\text { Latitude } \\
\text { (NAD 83) }\end{array}$ & $\begin{array}{l}\text { Longitude } \\
\text { (NAD 83) }\end{array}$ & $\begin{array}{l}\text { Altitude of land- } \\
\text { surface datum } \\
\text { (ft above NAVD 88) }\end{array}$ \\
\hline SACC1 & 344520120174001 & 008N032W19M001S & $8 \mathrm{~N} / 32 \mathrm{~W}-19 \mathrm{M} 1$ & 34.75568889 & -120.2946806 & 586.08 \\
\hline $\mathrm{SACC} 2$ & 344520120174002 & 008N032W19M002S & $8 \mathrm{~N} / 32 \mathrm{~W}-19 \mathrm{M} 2$ & 34.75568889 & -120.2946806 & 586.08 \\
\hline $\mathrm{SACC} 3$ & 344520120174003 & 008N032W19M003S & $8 \mathrm{~N} / 32 \mathrm{~W}-19 \mathrm{M} 3$ & 34.75568889 & -120.2946806 & 586.08 \\
\hline SACC4 & 344520120174004 & 008N032W19M004S & $8 \mathrm{~N} / 32 \mathrm{~W}-19 \mathrm{M} 4$ & 34.75568889 & -120.2946806 & 586.08 \\
\hline SACC5 & 344520120174005 & 008N032W19M005S & $8 \mathrm{~N} / 32 \mathrm{~W}-19 \mathrm{M} 5$ & 34.75575 & -120.29465 & 586.21 \\
\hline SACR1 & 344532120233901 & 008N033W19K002S & $8 \mathrm{~N} / 33 \mathrm{~W}-19 \mathrm{~K} 2$ & 34.75905833 & -120.3944083 & 362.98 \\
\hline SACR2 & 344532120233902 & 008N033W19K003S & $8 \mathrm{~N} / 33 \mathrm{~W}-19 \mathrm{~K} 3$ & 34.75905833 & -120.3944083 & 362.98 \\
\hline SACR3 & 344532120233903 & 008N033W19K004S & $8 \mathrm{~N} / 33 \mathrm{~W}-19 \mathrm{~K} 4$ & 34.75905833 & -120.3944083 & 362.98 \\
\hline SACR4 & 344532120233904 & 008N033W19K005S & $8 \mathrm{~N} / 33 \mathrm{~W}-19 \mathrm{~K} 5$ & 34.75905833 & -120.3944083 & 362.98 \\
\hline SACR5 & 344532120233905 & 008N033W19K006S & $8 \mathrm{~N} / 33 \mathrm{~W}-19 \mathrm{~K} 6$ & 34.759075 & -120.3943333 & 362.45 \\
\hline SAGR & 344622120254301 & 008N034W14L002S & $8 \mathrm{~N} / 34 \mathrm{~W}-14 \mathrm{~L} 2$ & 34.77286389 & -120.4285472 & 329.64 \\
\hline SAHC & 344836120270001 & 009N034W34N002S & $9 \mathrm{~N} / 34 \mathrm{~W}-34 \mathrm{~N} 2$ & 34.81 & -120.4501194 & 453.18 \\
\hline SAHG & 344546120253101 & 008N034W23H001S & $8 \mathrm{~N} / 34 \mathrm{~W}-23 \mathrm{H} 1$ & 34.76298333 & -120.4252722 & 320.63 \\
\hline SALA & 344436120161701 & 008N032W29L004S & $8 \mathrm{~N} / 32 \mathrm{~W}-29 \mathrm{~L} 4$ & 34.74351111 & -120.2714944 & 596.47 \\
\hline SALS & 344524120202001 & 008N033W22G001S & $8 \mathrm{~N} / 33 \mathrm{~W}-22 \mathrm{G} 1$ & 34.75660556 & -120.3389167 & 459.5 \\
\hline SASA & 344548120274201 & 008N034W21A002S & $8 \mathrm{~N} / 34 \mathrm{~W}-21 \mathrm{~A} 2$ & 34.76328333 & -120.4617667 & 309.65 \\
\hline
\end{tabular}


data were analyzed to determine the number, diameter, type of well(s), and depths of screened intervals to be placed in each deep borehole. At each shallow borehole, lithologic and groundwater-level data were used to select the screened interval and auger methods were used to prevent mud intrusion and to allow for monitoring of the water table.

Six single-depth, monitoring-well sites (SMWS; SASA, SAHC, SAGR, SAHG, SALS, and SALA; table 1.2; U.S. Geological Survey, 2018, 2021) were installed at selected locations in the shallow part of the aquifer system, at or near the water table (fig. 17). Each SMWS consists of a shallow borehole (about $100 \mathrm{ft}$ deep; U.S. Geological Survey, 2018) with a single monitoring well completed at the bottom of the borehole. These well sites were installed near existing production wells or other wells in which groundwater levels were regularly monitored. The purpose of the SMWS was to quantify vertical variations in groundwater levels and water quality in the upper part of the aquifer system. The SMWS boreholes were drilled using a hollow-stem auger method, and electromagnetic induction borehole-geophysical logs were collected at each borehole. Lithologic and groundwater-level data were used to select the screened interval. Auger methods were used at each SMWS to prevent mud intrusion and to allow for monitoring of the water table.

Well construction at each MMWS and SMWS began with the casing and screen being placed in the borehole to the desired depth. Well casings had a diameter of about 2 inches. Adjacent to and extending above and below the screened intervals, the boreholes were packed with number 3 Monterey sand. Sand-packed intervals in each borehole were isolated by bentonite grout ( 30 percent solids) pumped into the annular space. In the multiple-well monitoring sites, this method was repeated for each well. The bentonite seal was extended to land surface in all boreholes. Well sites were then protected and secured by a flush-mount traffic-rated vault, maintenance-hole or steel stovepipe with a cement pad.

Location information and well-construction data for each MMWS and SMWS are listed in table 1.2. Composite diagrams of the well construction, borehole lithology, and geophysical logs for each well site can be found in the U.S. Geological Survey (USGS) GeoLog Locator (U.S. Geological Survey, 2018; search by USGS station number or station name listed in table 1.2).

Table 1.2. Locations of U.S. Geological Survey (USGS) single- and multiple-well monitoring sites and well-construction information, San Antonio Creek Valley watershed, Santa Barbara County, California.

[Type and purpose of well: MMWS, multiple-depth monitoring-well site; SMWS, single-depth monitoring-well site. Type of seal: G, grout; GC, grout and bentonite chips; GP, grout and bentonite pellets; GPC, grout bentonite pellets and bentonite chips; CGr, bentonite chips and granular bentonite. Abbreviations: NAD 83, North American Datum of 1983; ft, feet; NAVD 88, North American Vertical Datum of 1988; BLSD, below land surface datum; mm/dd/yyyy, month/day/year]

\begin{tabular}{cccccccc}
\hline $\begin{array}{c}\text { Type and } \\
\text { purpose } \\
\text { of well }\end{array}$ & $\begin{array}{c}\text { Depth of } \\
\text { well } \\
\text { (ft BLSD) }\end{array}$ & $\begin{array}{c}\text { Sand- pack } \\
\text { interval } \\
\text { (ft BLSD) }\end{array}$ & $\begin{array}{c}\text { Seal interval } \\
\text { (ft BLSD) }\end{array}$ & $\begin{array}{c}\text { Type } \\
\text { of seal }\end{array}$ & $\begin{array}{c}\text { Perforated } \\
\text { interval } \\
\text { (ft BLSD) }\end{array}$ & $\begin{array}{c}\text { Inner diameter } \\
\text { of well } \\
\text { (inches) }\end{array}$ & $\begin{array}{c}\text { Date drilled } \\
\text { (mm/dd/yyyy) }\end{array}$ \\
\hline MMWS & 980 & $890-986$ & $745-890$ & G & $920-940$ & 1.94 & $07 / 28 / 2016$ \\
MMWS & 720 & $675-745$ & $552-675$ & G & $700-720$ & 1.94 & $07 / 28 / 2016$ \\
MMWS & 530 & $496-552$ & $347-496$ & GP & $510-530$ & 1.94 & $07 / 28 / 2016$ \\
MMWS & 325 & $285-347$ & $0-285$ & GP & $305-325$ & 1.94 & $07 / 28 / 2016$ \\
SMWS & 120 & $90-120$ & $90-0$ & GPC & $100-120$ & 1.94 & $11 / 21 / 2016$ \\
MMWS & 690 & $655-700$ & $552-655$ & G & $670-690$ & 1.94 & $08 / 06 / 2016$ \\
MMWS & 540 & $490-552$ & $366-490$ & GP & $520-540$ & 1.94 & $08 / 06 / 2016$ \\
MMWS & 350 & $306-366$ & $190-306$ & GPC & $330-350$ & 1.94 & $08 / 06 / 2016$ \\
MMWS & 220 & $190-228$ & $190-0$ & GPC & $200-220$ & 1.94 & $08 / 06 / 2016$ \\
SMWS & 110 & $80-110$ & $0-80$ & GC & $90-110$ & 1.94 & $11 / 19 / 2016$ \\
SMWS & 90 & $61-90$ & $0-61$ & CGr & $70-90$ & 1.94 & $10 / 18 / 2015$ \\
SMWS & 90 & $60-90$ & $0-60$ & CGr & $70-90$ & 1.94 & $10 / 15 / 2015$ \\
SMWS & 75 & $42-75$ & $0-75$ & GP & $55-75$ & 1.94 & $12 / 01 / 2016$ \\
SMWS & 90 & $60-90$ & $0-60$ & GP & $70-90$ & 1.94 & $11 / 25 / 2016$ \\
SMWS & 70 & $40-70$ & $0-40$ & GP & $50-70$ & 1.94 & $11 / 21 / 2016$ \\
SMWS & 65 & $35-65$ & $0-35$ & CGr & $45-65$ & 1.94 & $10 / 16 / 2015$ \\
\hline
\end{tabular}




\section{Specific Capacity Estimates From Water Wells}

Specific capacity data were calculated for 28 water wells with reported aquifer pump test data (table 1.3; Ely and others, 2022). Calculated specific capacity results were assigned to hydrogeologic units for which at least 60 percent of the reported perforation interval intersected a given unit. A value of 60 percent of the perforation interval intersection was chosen to provide a reasonable distribution of specific capacity estimates for each hydrogeologic unit. Specific capacity data were calculated for the upper, middle, and lower members of the Paso Robles Formation, and the Careaga Sandstone. Specific capacity data were not available for the channel alluvium unit for water wells compiled as part of this study.
Table 1.3. Calculated specific capacity data for selected boreholes with reported pump test information, San Antonio Creek Valley Watershed, Santa Barbara County, California.

[g/m/ft, gallon per minute per foot]

\begin{tabular}{|c|c|c|}
\hline $\begin{array}{c}\text { California } \\
\text { Department } \\
\text { of Water Resources } \\
\text { legacy log number }\end{array}$ & $\begin{array}{c}\text { Specific capacity, } \\
\text { in } \mathrm{g} / \mathrm{m} / \mathrm{ft} \\
\text { of drawdown }\end{array}$ & $\begin{array}{c}\text { Percent of } \\
\text { perforated interval } \\
\text { in hydrogeologic unit }\end{array}$ \\
\hline \multicolumn{3}{|c|}{ Upper Paso Robles Formation } \\
\hline 240633 & 2.6 & 100 \\
\hline \multicolumn{3}{|c|}{ Middle Paso Robles Formation } \\
\hline 763319 & 12.22 & 100 \\
\hline \multicolumn{3}{|c|}{ Lower Paso Robles Formation } \\
\hline 757863 & 1.78 & 100 \\
\hline 95702 & 2.87 & 100 \\
\hline 757872 & 3.02 & 100 \\
\hline 35757 & 3.3 & 100 \\
\hline 925735 & 3.82 & 100 \\
\hline 907247 & 5.71 & 100 \\
\hline 97948 & 14.7 & 95 \\
\hline 470087 & 16.7 & 100 \\
\hline 521842 & 17.9 & 61 \\
\hline \multicolumn{3}{|c|}{ Careaga Sandstone } \\
\hline 161097 & 0.3 & 100 \\
\hline 763326 & 0.34 & 100 \\
\hline 287832 & 0.77 & 100 \\
\hline 757864 & 1.09 & 100 \\
\hline 287808 & 2.0 & 100 \\
\hline 763328 & 2.4 & 84 \\
\hline 374707 & 2.86 & 100 \\
\hline 710802 & 3.59 & 100 \\
\hline 765727 & 4.15 & 100 \\
\hline 240630 & 5.0 & 98 \\
\hline 907652 & 5.15 & 69 \\
\hline 287807 & 6.0 & 100 \\
\hline 710824 & 13.59 & 100 \\
\hline 700853 & 16.9 & 100 \\
\hline 77511 & 24.8 & 63 \\
\hline 31100 & 27.8 & 88 \\
\hline 1098082 & 83.3 & 100 \\
\hline
\end{tabular}




\section{References Cited}

Blasch, K.W., Ferré, T.P.A., Christensen, A.H., and Hoffmann, J.P., 2002, New Field Method to Determine Streamflow Timing Using Electrical Resistance Sensors: Vadose Zone Journal, v. 1, no. 2, p. 289-299. [Available at https://doi.org/10.2136/vzj2002.2890.]

Chapin, T.P., Todd, A.S., and Zeigler, M.P., 2014, Robust, low-cost data loggers for stream temperature, flow intermittency, and relative conductivity monitoring: Water Resources Research, v. 50, no. 8, p. 6542-6548. [Available at https://doi.org/10.1002/2013WR015158.]

Hutchinson, C.B., 1980, Appraisal of Groundwater Resources in the San Antonio Creek Valley, Santa Barbara County, California: U.S. Geological Survey Open-File Report 80-750, 48 p. [Available at https://doi.org/10.3133/ofr80750.]

Tadayon, S., Duet, N.R., Fisk, G.G., McCormack, H.F., Partin, C.K., Pope, G.L., and Rigas, P.D., 2001, Water resources data, Arizona, water year 2000: U.S. Geological Survey Water Data Report AZ-00-1, 390 p. [Available at https://doi.org/10.3133/wdrAZ001.]
Tetra Tech, Inc., 2012, Final historical water balance of the San Antonio Groundwater Basin: Pasadena, California, Tetra Tech, Inc., prepared for Vandenberg Air Force Base, California, $96 \mathrm{p}$.

U.S. Census Bureau, 2000, Decennial census of population and housing - By decade, 2000, accessed September 11, 2019, at https://www.census.gov/programs-surveys/ decennial-census/decade.2000.html.

U.S. Census Bureau, 2010, Decennial census of population and housing - By decade, 2010, accessed September 11, 2019, at https://www.census.gov/programs-surveys/ decennial-census/decade.2010.html.

U.S. Census Bureau, 2020, Decennial census of population and housing - By decade, 2020, accessed December 11, 2021, at https://www.census.gov/programs-surveys/ decennial-census/decade.2020.html.

U.S. Geological Survey, 2018, USGS GeoLog Locator, accessed September 30, 2018, at https://doi.org/10.5066/F7X63KT0.

U.S. Geological Survey, 2021, USGS water data for the Nation: U.S. Geological Survey National Water Information System database, accessed September 8, 2021, at https://doi.org/10.5066/F7P55KJN. 


\section{Appendix 2. Water Quality}

This appendix contains water-quality data sampled during 1980-2018 from select surface-water sites and groundwater wells in the San Antonio Creek Valley Watershed (SACVW). Also included in this appendix is a description of the methods and possible outcomes of reduction/oxidation (redox) categories and processes of the Excel Workbook of Jurgens and others (2009) used to assess redox conditions in groundwater from select wells in the SACVW.

\section{Selected Water-Quality Data}

This section contains a suite of selected water-quality data sampled during 1980-2018 from select groundwater wells and surface-water sites (table 9) in the San Antonio Creek Valley Watershed (SACVW). All data were downloaded from the U.S. Geological Survey National (NWIS) database and can be accessed at https://waterdata.usgs.gov/ca/nwis (U.S. Geological Survey, 2021).

\section{Other Constituents of Concern}

Other selected water-quality constituents of potential concern are arsenic, iron, manganese, and molybdenum. Concentrations of these constituents in samples from some wells exceeded State or Federal recommended or mandatory regulatory standards for drinking water.

Arsenic, a tasteless, odorless, semi-metallic element, can be present in surface water and groundwater from natural and anthropogenic sources. In the natural environment, arsenic is most commonly associated with sulfide and with ferromanganese-oxide minerals, particularly in areas characterized by geothermal water or high-evaporation rates (Welch and others, 2000). Arsenic from anthropogenic sources include wood preservatives, pesticides, and use as a semi-conductor in the manufacture of microelectronics (Agency for Toxic Substances and Disease Registry, 2009). Industrial and agricultural uses of arsenic have been reduced in the United States over the last several decades because of the increasing recognition of its threat to human health (Agency for Toxic Substances and Disease Registry, 2009). The U.S. Environmental Protection Agency (EPA) maximum contaminant level (MCL) for arsenic is 10 micrograms per liter $(\mu \mathrm{g} / \mathrm{L})$; long-term exposure to arsenic in water exceeding this concentration can cause a variety of dermal, cardiovascular, respiratory, and neurological ailments, as well as an increased risk of some cancers (U.S. Environmental Protection Agency, 2006, 2017b). Five wells sampled during 2017-18 had arsenic concentrations greater than to the MCL of $10 \mu \mathrm{g} / \mathrm{L}$ (U.S. Geological Survey, 2021). Two wells sampled during 1980-2008 had arsenic concentrations greater than to the MCL of $10 \mu \mathrm{g} / \mathrm{L}$, but these wells were not resampled during 2017-18. The highest arsenic concentration reported for wells sampled during 1980-2008 was $36.4 \mu \mathrm{g} / \mathrm{L}$ from well SAHG (fig. 36; U.S. Geological Survey, 2021), which could be the result of reduced (anoxic) conditions in groundwater (see "Reduction/Oxidation Conditions of Groundwater" section).

Iron is derived from natural weathering of many rocks and minerals with high iron content, such as pyroxenes, amphiboles, biotite, magnetite, and olivine (Hem, 1992). Iron is readily dissolved in the form of ferrous $\left(\mathrm{Fe}^{2+}\right)$ iron, when exposed to anoxic or suboxic conditions and low to near neutral $\mathrm{pH}$. Iron is much less soluble in the form of ferric $\left(\mathrm{Fe}^{3+}\right)$ iron under oxidizing conditions (dissolved oxygen greater than 1-2 $\mathrm{mg} / \mathrm{L}$ ), and at all but a low $\mathrm{pH}$ (Hem, 1992). The EPA Secondary MCL for iron is $300 \mu \mathrm{g} / \mathrm{L}$ (U.S. Environmental Protection Agency, 2017a). Excessive amounts of iron can cause aesthetic effects, such as an objectionable metallic taste and turning water a reddish or orange color that can stain plumbing fixtures and other surfaces, but normally, it does not pose a health risk. Excessive iron can also have economic implications, including corrosion and encrustation of steel well casing, perforations, and related infrastructure. Six wells sampled during 2017-18 had iron concentrations greater than to the MCL of $300 \mu \mathrm{g} / \mathrm{L}$ (U.S. Geological Survey, 2021). Twelve wells sampled during 1980-2008 had iron concentrations greater than the MCL of $300 \mu \mathrm{g} / \mathrm{L}$ (some wells had multiple samples that exceeded the MCL during this period). The highest iron concentrations reported for wells sampled during 1980-2018 were generally about $2,000-5,300 \mu \mathrm{g} / \mathrm{L}$; however, one sample from well $9 \mathrm{~N} / 34 \mathrm{~W}-27 \mathrm{~L} 1$ has a reported iron concentration of 94,000 $\mu \mathrm{g} / \mathrm{L}$ (U.S. Geological Survey, 2021).

Manganese is derived from natural weathering of many rocks, such as basalt, and minerals, such as olivine, pyroxene, and amphibole (Hem, 1992). Manganese, like iron, dissolves under reducing conditions (dissolved oxygen is low) and low to near-neutral $\mathrm{pH}$. In the presence of oxygen and carbonate or silicate at high $\mathrm{pH}$, manganese precipitates out of solution and forms black-colored deposits that are unpleasant in appearance and taste in drinking water (Hem, 1992). At concentrations above the EPA Secondary MCL of $50 \mu \mathrm{g} / \mathrm{L}$ (U.S. Environmental Protection Agency, 2017a), manganese can have a metallic taste and cause staining of plumbing fixtures and other surfaces, but normally, it does not pose a health risk. Twenty wells sampled during 2017-18 had manganese concentrations greater than or equal to the MCL of $50 \mu \mathrm{g} / \mathrm{L}$ (U.S. Geological Survey, 2021). Thirteen wells sampled during 1980-2014 had manganese concentrations greater than the SMCL of $50 \mu \mathrm{g} / \mathrm{L}$ (some wells had multiple samples that exceeded the SMCL during this period). The highest manganese concentration reported is $1,090 \mu \mathrm{g} / \mathrm{L}$, which was measured in a sample from well 9N/34W-27L1 during the 2017-18 sampling period (table 10). 
Molybdenum plays an important biological role as a micronutrient for plants and animals; but at high levels, it can be toxic to animals (Smedley and Kinniburgh, 2017). Concentrations in surface waters are generally less than $5 \mu \mathrm{g} / \mathrm{L}$, although concentrations as high as $500 \mu \mathrm{g} / \mathrm{L}$ have been reported in some drinking waters (World Health Organization, 2011). Concentrations in water greater than $20 \mu \mathrm{g} / \mathrm{L}$ are likely due to anthropogenic inputs. The EPA health-based advisory level is $40 \mu \mathrm{g} / \mathrm{L}$ for molybdenum (U.S. Environmental Protection Agency, 2006). Molybdenum concentrations greater than or equal to the MCL of $40 \mu \mathrm{g} / \mathrm{L}$ were observed in ten wells sampled during 2017-18 and five wells sampled during 1980-2008 (U.S. Geological Survey, 2021). The highest molybdenum concentration reported for wells sampled during 1980-2018 was $363 \mu \mathrm{g} / \mathrm{L}$, which was measured in a sample from well 2N1 during the 2017-18 sampling period (U.S. Geological Survey, 2021).

\section{Reduction/0xidation Conditions of Groundwater}

This section describes the methods and possible outcomes of redox categories and processes of the Excel Workbook of Jurgens and others (2009), which was used to assess redox conditions in groundwater from select wells in the SACVW (see "Groundwater Quality" section). The Microsoft Excel® workbook of Jurgens and others (2009), RedoxAssignment_McMahon\&Chapelle.xls, assigns the predominant redox process to water-quality samples using the framework created by McMahon and Chapelle (2008) and extended by Chapelle and others (2009; table 2.1).

The following text and tables are copied verbatim from the "Methods" section of Jurgens and others (2009) — table names within this text have been updated to indicate their inclusion in this report:

The possible outcomes of redox categories and processes were differentiated by the number and type of parameters input into the program (table 2.2). Samples that had $\mathrm{O}_{2}, \mathrm{NO}_{3}{ }^{-}, \mathrm{Mn}^{2+}$, $\mathrm{Fe}^{2+}$, and $\mathrm{SO}_{4}{ }^{2-}$ were considered complete and the possible outcomes of redox categories and processes were determined by the logic outlined in the upper-half of table 2.2. The possible outcomes for samples that have sulfide in addition to these five parameters are also included in the upper half of table 2.2. NOTE: The actual implementation of the logic into VBA code [Microsoft $®$ Visual Basic $®$ for Applications] is different than the simple "Yes," "No" arguments in table 2.2. The logic used in the code was designed to execute more efficiently for a large number of samples. Table 2.2 is a reference for users to understand the general logic behind each redox assignment.

The redox categories listed in the upper half of table 2.2 are the same or similar to the categories listed by McMahon and Chapelle (2008). The Mixed category was further defined to indicate whether the mixture had two anoxic redox processes $(\mathrm{Mixed}[\mathrm{anoxic}])$ or an oxic $\left(\mathrm{O}_{2}\right.$-reducing) and an anoxic redox process (Mixed[oxic-anoxic]). The redox processes comprising the mixture is separated by a "-." (meaning and). For example, a redox process " $\mathrm{NO}_{3}-\mathrm{Mn}(\mathrm{IV})$ " is a mixture of nitrate- and manganese-reducing groundwater. Because both of these redox processes are anoxic, the redox category is "Mixed(anoxic)."

Samples that have fewer than the five parameters listed above were considered incomplete, and the possible outcomes of redox categories and processes are listed in the bottom half of table 2.2. These samples were further differentiated into two groups: (1) samples that have measured $\mathrm{O}_{2}$ but are missing one or more of the other four redox constituents, and (2) samples missing $\mathrm{O}_{2}$, but have $\mathrm{NO}_{3}{ }^{-}, \mathrm{Mn}^{2+}, \mathrm{Fe}^{2+}$, and $\mathrm{SO}_{4}{ }^{2-}$. Samples collected for regulatory compliance purposes are often analyzed for major ions, trace elements, and nutrients, but usually not for dissolved $\mathrm{O}_{2}$. Redox processes for these samples would be assigned using the logic of the second group. However, water-quality samples collected for compliance purposes may not have been filtered or preserved (acidified), and (or) may have been treated or blended. Users should always evaluate the source and quality of data to determine if the data are suitable for redox classification.

Samples that have dissolved $\mathrm{O}_{2}$ data but are missing data for one or more of the other four constituents, will have a general redox category of either " $\mathrm{O}_{2} \geq 0.5 \mathrm{mg} / \mathrm{L}$ " or " $\mathrm{O}_{2}<0.5 \mathrm{mg} / \mathrm{L}$." These two categories are used to distinguish between predominately oxic and anoxic conditions.

Samples that are missing dissolved $\mathrm{O}_{2}$ but have measured $\mathrm{NO}_{3}{ }^{-}, \mathrm{Mn}^{2+}, \mathrm{Fe}^{2+}$, and $\mathrm{SO}_{4}{ }^{2-}$ will be assigned a redox category and process that is consistent with the framework in table 2.1. However, each redox process is amended with a prefix or suffix of " $\mathrm{O}_{2}$ ?" or " $\mathrm{O}_{2}$ ? $\mathrm{OrNO}_{3}$ " to indicate that dissolved oxygen was not measured and could be present above the threshold concentration (table 2.2). The general redox category is also amended to indicate the two possible redox categories for $\mathrm{O}_{2}$ above or below the threshold. The first redox category indicates the predominant redox category that would be consistent with the other measured data, and the second category indicates the less likely category. For example, a sample that has low nitrate $(<0.5$ milligrams per liter $[\mathrm{mg} / \mathrm{L}])$ and high iron and sulfate $(100 \mu \mathrm{g} / \mathrm{L}$ and $>0.5 \mathrm{mg} / \mathrm{L}$, respectively) is consistent with an $\mathrm{Fe}(\mathrm{III}) / \mathrm{SO}_{4}{ }^{2-}$ reducing redox environment, so the presence of oxygen would not be expected. Therefore, the general redox category for this sample would be "AnoxicOrMixed(oxic-anoxic)" to indicate this sample is most likely anoxic but would be a mixed sample if dissolved $\mathrm{O}_{2}$ was greater than $0.5 \mathrm{mg} / \mathrm{L}$. Conversely, a sample containing high $\mathrm{NO}_{3}{ }^{-}$and low $\mathrm{Mn}^{2+}$ and $\mathrm{Fe}^{2+}$, is consistent with an $\mathrm{O}_{2}{ }^{-}$and a $\mathrm{NO}_{3}{ }^{-}$reducing environment, as indicated by the " $\mathrm{O}_{2}$ ? $\mathrm{OrNO}_{3}$ " designation in table 2.2. McMahon and Chapelle (2008) showed that most groundwater samples (greater than 50 percent) tend to be $\mathrm{O}_{2}$ reducing while only a small percentage (less than 4 percent) tend to be $\mathrm{NO}_{3}^{-}$ reducing for many hydrogeologic settings. Consequently, these samples are assigned a general redox category of "OxicOrAnoxic" to indicate that the oxic condition is more likely than the anoxic condition, although this assumption may not be valid in some settings. 


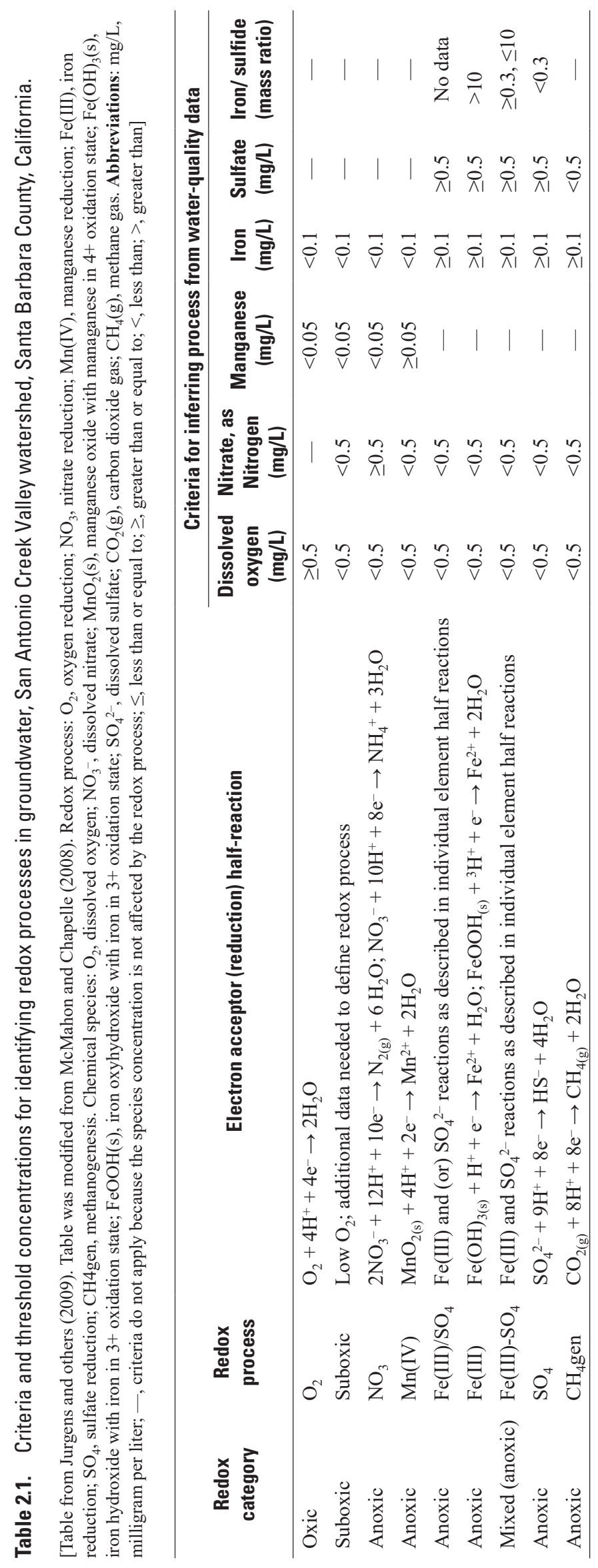


Table 2.2. Classification of redox categories and processes assigned on the basis of water-quality data

[Table from Jurgens and others (2009). Redox category: $\mathrm{O}_{2} \geq 0.5 \mathrm{mg} / \mathrm{L}$, dissolved oxygen greater than or equal to $0.5 \mathrm{mg} / \mathrm{L} ; \mathrm{O}_{2}<0.5 \mathrm{mg} / \mathrm{L}$, dissolved oxygen less than $0.5 \mathrm{mg} / \mathrm{L}$. Redox process: $\mathrm{O}_{2}$, oxygen reduction; $\mathrm{NO}_{3}$, nitrate reduction; $\mathrm{Mn}(\mathrm{IV})$, manganese reduction; Fe(III), iron reduction; $\mathrm{SO} \mathrm{H}_{4}$, sulfate reduction; CH4gen, methanogenesis. Abbreviations: mg/L, milligram per liter; $<$, less than; $\leq$, less than or equal to; $\geq$, greater than or equal to; >, greater than; Y, yes; N, no; - , criteria do not apply because the species concentration is not affected by the redox process; ?, insufficient data to determine whether process is occurring or not; /, and (or); -, and; $\mathrm{x}$, not applicable]

\begin{tabular}{|c|c|c|c|c|c|c|c|c|}
\hline Redox category & Redox process & $\begin{array}{c}\text { Dissolved } \\
\text { oxygen } \\
>0.5 \mathrm{mg} / \mathrm{L}\end{array}$ & $\begin{array}{c}\text { Nitrate, as } \\
\text { Nitrogen } \\
>0.5 \mathrm{mg} / \mathrm{L}\end{array}$ & $\begin{array}{c}\text { Manganese } \\
>0.05 \mathrm{mg} / \mathrm{L}\end{array}$ & $\begin{array}{l}\text { Iron } \\
>0.01 \\
\mathrm{mg} / \mathrm{L}\end{array}$ & $\begin{array}{l}\text { Sulfate } \\
>0.5 \\
\mathrm{mg} / \mathrm{L}\end{array}$ & $\begin{array}{c}\text { Iron/sulfide } \\
\text { mass ratio } \\
>0.3\end{array}$ & $\begin{array}{c}\text { Iron/sulfide } \\
\text { mass ratio } \\
>10\end{array}$ \\
\hline \multicolumn{9}{|c|}{ Water-quality data complete } \\
\hline Oxic & $\mathrm{O}_{2}$ & $\mathrm{Y}$ & - & $\mathrm{N}$ & $\mathrm{N}$ & - & $\mathrm{x}$ & $\mathrm{x}$ \\
\hline Suboxic & Suboxic & $\mathrm{N}$ & $\mathrm{N}$ & $\mathrm{N}$ & $\mathrm{N}$ & - & $\mathrm{x}$ & $\mathrm{x}$ \\
\hline Anoxic & $\mathrm{NO}_{3}$ & $\mathrm{~N}$ & $\mathrm{Y}$ & $\mathrm{N}$ & $\mathrm{N}$ & - & $\mathrm{x}$ & $\mathrm{x}$ \\
\hline Anoxic & $\mathrm{Mn}(\mathrm{IV})$ & $\mathrm{N}$ & $\mathrm{N}$ & $\mathrm{Y}$ & $\mathrm{N}$ & - & $\mathrm{x}$ & $\mathrm{x}$ \\
\hline Anoxic & $\mathrm{Fe}(\mathrm{III}) / \mathrm{SO}_{4}$ & $\mathrm{~N}$ & $\mathrm{~N}$ & - & $\mathrm{Y}$ & $\mathrm{Y}$ & No data & No data \\
\hline Anoxic & CH4gen & $\mathrm{N}$ & $\mathrm{N}$ & - & $\mathrm{Y}$ & $\mathrm{N}$ & $\mathrm{x}$ & $\mathrm{x}$ \\
\hline Mixed (oxic-anoxic) & $\mathrm{O}_{2}-\mathrm{Mn}(\mathrm{IV})$ & $\mathrm{Y}$ & - & $\mathrm{Y}$ & $\mathrm{N}$ & - & $\mathrm{x}$ & $\mathrm{x}$ \\
\hline Mixed (oxic-anoxic) & $\mathrm{O}_{2}-\mathrm{Fe}(\mathrm{III}) / \mathrm{SO}_{4}$ & $\mathrm{Y}$ & $\mathrm{N}$ & - & $\mathrm{Y}$ & Y & No data & No data \\
\hline Mixed (oxic-anoxic) & $\mathrm{O}_{2}-\mathrm{CH} 4$ gen & $\mathrm{Y}$ & $\mathrm{N}$ & - & $\mathrm{Y}$ & $\mathrm{N}$ & $\mathrm{x}$ & $\mathrm{x}$ \\
\hline Mixed (anoxic) & $\mathrm{NO}_{3}-\mathrm{Mn}(\mathrm{IV})$ & $\mathrm{N}$ & $\mathrm{Y}$ & $\mathrm{Y}$ & $\mathrm{N}$ & - & $\mathrm{x}$ & $\mathrm{x}$ \\
\hline Mixed (anoxic) & $\mathrm{NO}_{3}-\mathrm{Fe}(\mathrm{III}) / \mathrm{SO}_{4}$ & $\mathrm{~N}$ & $\mathrm{Y}$ & - & $\mathrm{Y}$ & $\mathrm{Y}$ & No data & No data \\
\hline Mixed (anoxic) & $\mathrm{NO}_{3}-\mathrm{CH}_{4}$ gen & $\mathrm{N}$ & $\mathrm{Y}$ & - & Y & $\mathrm{N}$ & $\mathrm{x}$ & $\mathrm{x}$ \\
\hline Anoxic & $\mathrm{SO}_{4}$ & $\mathrm{~N}$ & $\mathrm{~N}$ & - & $\mathrm{Y}$ & Y & $\mathrm{N}$ & $\mathrm{N}$ \\
\hline Mixed (anoxic) & $\mathrm{Fe}(\mathrm{III})-\mathrm{SO}_{4}$ & $\mathrm{~N}$ & $\mathrm{~N}$ & - & $\mathrm{Y}$ & Y & $\mathrm{Y}$ & $\mathrm{N}$ \\
\hline Anoxic & $\mathrm{Fe}(\mathrm{III})$ & $\mathrm{N}$ & $\mathrm{N}$ & - & $\mathrm{Y}$ & Y & $\mathrm{Y}$ & $\mathrm{Y}$ \\
\hline Mixed (oxic-anoxic) & $\mathrm{O}_{2}-\mathrm{SO}_{4}$ & $\mathrm{Y}$ & $\mathrm{N}$ & - & $\mathrm{Y}$ & $\mathrm{Y}$ & $\mathrm{N}$ & $\mathrm{N}$ \\
\hline Mixed (oxic-anoxic) & $\mathrm{O}_{2}-\mathrm{Fe}(\mathrm{III})-\mathrm{SO}_{4}$ & Y & $\mathrm{N}$ & - & Y & Y & $\mathrm{Y}$ & $\mathrm{N}$ \\
\hline Mixed (oxic-anoxic) & $\mathrm{O}_{2}-\mathrm{Fe}(\mathrm{IIII})$ & $\mathrm{Y}$ & $\mathrm{N}$ & - & $\mathrm{Y}$ & $\mathrm{Y}$ & $\mathrm{Y}$ & $\mathrm{Y}$ \\
\hline Mixed (anoxic) & $\mathrm{NO}_{3}-\mathrm{SO}_{4}$ & $\mathrm{~N}$ & $\mathrm{Y}$ & - & Y & Y & $\mathrm{N}$ & $\mathrm{N}$ \\
\hline Mixed (anoxic) & $\mathrm{NO}_{3}-\mathrm{Fe}(\mathrm{III})-\mathrm{SO}_{4}$ & $\mathrm{~N}$ & $\mathrm{Y}$ & - & Y & Y & $\mathrm{Y}$ & $\mathrm{N}$ \\
\hline Mixed (anoxic) & $\mathrm{NO}_{3}-\mathrm{Fe}(\mathrm{III})$ & $\mathrm{N}$ & $\mathrm{Y}$ & - & $\mathrm{Y}$ & $\mathrm{Y}$ & $\mathrm{Y}$ & $\mathrm{Y}$ \\
\hline \multicolumn{9}{|c|}{ Water-quality data incomplete } \\
\hline $\mathrm{O}_{2} \geq 0.5 \mathrm{mg} / \mathrm{L}$ & Unknown & $\mathrm{Y}$ & No data & No data & No data & No data & No data & No data \\
\hline $\mathrm{O}_{2}<0.5 \mathrm{mg} / \mathrm{L}$ & Unknown & $\mathrm{N}$ & No data & No data & No data & No data & No data & No data \\
\hline OxicOrAnoxic & $\mathrm{O}_{2}$ ? $\mathrm{OrNO}_{3}$ & No data & $\mathrm{Y}$ & $\mathrm{N}$ & $\mathrm{N}$ & $\mathrm{Y}$ & $\mathrm{x}$ & $\mathrm{x}$ \\
\hline OxicOrSuboxic & $\mathrm{O}_{2}$ ?OrSuboxic & No data & $\mathrm{N}$ & $\mathrm{N}$ & $\mathrm{N}$ & $\mathrm{N}$ & $\mathrm{x}$ & $\mathrm{x}$ \\
\hline AnoxicOrMixed(oxic-anoxic) & $\mathrm{Mn}(\mathrm{IV})-\mathrm{O}_{2} ?$ & No data & $\mathrm{N}$ & $\mathrm{Y}$ & $\mathrm{N}$ & - & $\mathrm{x}$ & $\mathrm{x}$ \\
\hline AnoxicOrMixed(oxic-anoxic) & $\mathrm{Fe}(\mathrm{III}) / \mathrm{SO}_{4}-\mathrm{O}_{2} ?$ & No data & $\mathrm{N}$ & - & $\mathrm{Y}$ & $\mathrm{Y}$ & No data & No data \\
\hline AnoxicOrMixed(oxic-anoxic) & $\mathrm{CH}_{4}$ gen- $\mathrm{O}_{2} ?$ & No data & $\mathrm{N}$ & - & $\mathrm{Y}$ & $\mathrm{N}$ & $\mathrm{x}$ & $\mathrm{x}$ \\
\hline $\begin{array}{l}\text { Mixed(anoxic) } \\
\text { Or(oxic-anoxic) }\end{array}$ & $\mathrm{Mn}(\mathrm{IV})-\mathrm{O}_{2}$ ? Or NO${ }_{3}$ & No data & $\mathrm{Y}$ & $\mathrm{Y}$ & $\mathrm{N}$ & - & $\mathrm{x}$ & $\mathrm{x}$ \\
\hline $\begin{array}{l}\text { Mixed(anoxic) } \\
\text { Or(oxic-anoxic) }\end{array}$ & $\begin{array}{l}\mathrm{Fe}(\mathrm{III}) / \\
\mathrm{SO}_{4}-\mathrm{O}_{2}\end{array} \mathrm{OrNO}_{3}$ & No data & $\mathrm{Y}$ & - & $\mathrm{Y}$ & $\mathrm{Y}$ & No data & No data \\
\hline $\begin{array}{l}\text { Mixed(anoxic) } \\
\text { Or(oxic-anoxic) }\end{array}$ & $\mathrm{CH}_{4}$ gen- $\mathrm{O}_{2}$ ? $\mathrm{OrNO}_{3}$ & No data & Y & - & $\mathrm{Y}$ & $\mathrm{N}$ & $\mathrm{x}$ & $\mathrm{x}$ \\
\hline AnoxicOrMixed(oxic-anoxic) & $\mathrm{SO}_{4}-\mathrm{O}_{2} ?$ & No data & $\mathrm{N}$ & $\mathrm{Y}$ & $\mathrm{Y}$ & Y & $\mathrm{N}$ & $\mathrm{N}$ \\
\hline Mixed(anoxic) & $\mathrm{Fe}(\mathrm{III})-\mathrm{SO}_{4}-\mathrm{O}_{2} ?$ & No data & $\mathrm{N}$ & $\mathrm{Y}$ & $\mathrm{Y}$ & $\mathrm{Y}$ & Y & $\mathrm{N}$ \\
\hline AnoxicOrMixed(oxic-anoxic) & $\mathrm{Fe}(\mathrm{III})-\mathrm{O}_{2} ?$ & No data & $\mathrm{N}$ & $\mathrm{Y}$ & $\mathrm{Y}$ & Y & $\mathrm{Y}$ & Y \\
\hline Indeterminate & Unknown & No data & No data & No data & No data & No data & No data & No data \\
\hline
\end{tabular}




\section{References Cited}

Agency for Toxic Substances and Disease Registry, 2009, Case Studies in Environmental Medicine: Arsenic Toxicity, accessed May 1, 2011, at https://www.atsdr.cdc.gov/csem/arsenic/docs/arsenic.pdf.

Chapelle, F.H., Bradley, P.M., Thomas, M.A., and McMahon, P.B., 2009, Distinguishing iron-reducing from sulfate-reducing conditions: Ground Water, v. 47, no. 2, p. 300-305. [Available at https://doi.org/10.1111/j.1745-6584.2008.00536.x.]

Hem, J.D., 1992, Study and interpretation of the chemical characteristics of natural water (3d ed.): U.S. Geological Survey Water-Supply Paper 2254, 263 p., 3 plates. [Available at https://pubs.usgs.gov/wsp/wsp2254/pdf/wsp2254a.pdf.]

Jurgens, B.C., McMahon, P.B., Chapelle, F.H., and Eberts, S.M., 2009, An Excel workbook for identifying redox processes in ground water: U.S. Geological Survey Open-File Report 2009-1004, 8 p. [Available at https://doi.org/10.3133/ofr20091004.]

McMahon, P.B., and Chapelle, F.H., 2008, Redox processes and water quality of selected principal aquifer systems: Ground Water, v. 46, no. 2, p. 259-271. [Available at https://doi.org/10.1111/j.1745-6584.2007.00385.x.]

Smedley, P.L., and Kinniburgh, D.G., 2017, Molybdenum in natural waters-A review of occurrence, distributions and controls: Applied Geochemistry, v. 84, p. 387-432. [Available at https://doi.org/10.1016/j.apgeochem.2017.05.008.]
U.S. Environmental Protection Agency, 2006, 2006 Edition of the Drinking Water Standards and Health Advisories: Office of Water EPA 822-R-06-013. [Available at https://nepis.epa.gov/Exe/ZyPDF.cgi/P1004X78.PDF? Dockey=P1004X78.PDF.]

U.S. Environmental Protection Agency, 2017a, Secondary Drinking Water Standards: U.S. Environmental Protection Agency, accessed September 20, 2019, at https://www.epa.gov/sdwa/secondary-drinking-waterstandards-guidance-nuisance-chemicals.

U.S. Environmental Protection Agency, 2017b, National Primary Drinking Water Regulations: U.S. Environmental Protection Agency, accessed September 20, 2019, at https://www.epa.gov/ground-water-and-drinking-water/ national-primary-drinking-water-regulations.

U.S. Geological Survey, 2021, USGS water data for the Nation: U.S. Geological Survey National Water Information System database, accessed September 8, 2021, at https://doi.org/10.5066/F7P55KJN.

Welch, A.H., Westjohn, D.B., Helsel, D.R., and Wanty, R.B., 2000, Arsenic in Ground Water of the United States-Occurrence and Geochemistry: Ground Water, v. 38, no. 4, p. 589-604. [Available at https://doi.org/10.1111/j.1745-6584.2000.tb00251.x.]

World Health Organization, 2011, Molybdenum in Drinking Water: Background Document for Development of WHO Guidelines for Drinking-water Quality (WHO/ SDE/WSH/03.04/11/Rev/1); World Health Organization, Geneva, Switzerland. [Available at https://apps.who.int/iris/ bitstream/handle/10665/75372/WHO_SDE_WSH_03.04_ 11_eng.pdf.] 
For more information concerning the research in this report, contact the

Director, California Water Science Center

U.S. Geological Survey

6000 J Street, Placer Hall

Sacramento, California 95819

https://www.usgs.gov/centers/ca-water/

Publishing support provided by the U.S. Geological Survey

Science Publishing Network, Sacramento Publishing Service Center 


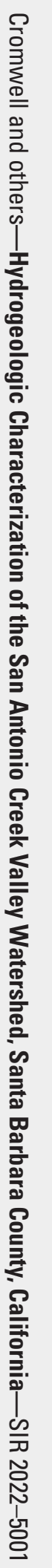

